\title{
English in Post-Revolutionary Iran
}




\section{NEW PERSPECTIVES ON LANGUAGE AND EDUCATION}

Series Editor: Professor Viv Edwards, University of Reading, Reading, Great Britain Series Advisor: Professor Allan Luke, Queensland University of Technology, Brisbane, Australia

Two decades of research and development in language and literacy education have yielded a broad, multidisciplinary focus. Yet education systems face constant economic and technological change, with attendant issues of identity and power, community and culture. This series will feature critical and interpretive, disciplinary and multidisciplinary perspectives on teaching and learning, language and literacy in new times.

Full details of all the books in this series and of all our other publications can be found on http://www.multilingual-matters.com, or by writing to Multilingual Matters, St Nicholas House, 31-34 High Street, Bristol BS1 2AW, UK. 


\section{English in Post-Revolutionary Iran}

\section{Maryam Borjian}




\title{
For Habib Borjian, For his scholarly input, boundless support, generous commitment, and endless love.
}

\author{
Library of Congress Cataloging in Publication Data \\ Borjian, Maryam. \\ English in Post-Revolutionary Iran/Maryam Borjian. \\ New Perspectives on Language and Education: 29 \\ Includes bibliographical references and index. \\ 1. English language-Study and teaching-Iran. 2. English language-Spoken English- \\ Iran. 3. Iran-Languages-Political aspects. 4. Language policy-Iran. 5. English \\ language-Foreign countries. I. Title \\ PE1068.I723B57 2013 \\ 428.0071'055-dc23 2012044139
}

\section{British Library Cataloguing in Publication Data}

A catalogue entry for this book is available from the British Library.

ISBN-13: 978-1-84769-909-1 (hbk)

ISBN-13: 978-1-84769-908-4 (pbk)

\section{Multilingual Matters}

UK: St Nicholas House, 31-34 High Street, Bristol BS1 2AW, UK.

USA: UTP, 2250 Military Road, Tonawanda, NY 14150, USA.

Canada: UTP, 5201 Dufferin Street, North York, Ontario M3H 5T8, Canada.

Copyright (C) 2013 Maryam Borjian.

All rights reserved. No part of this work may be reproduced in any form or by any means without permission in writing from the publisher.

The policy of Multilingual Matters/Channel View Publications is to use papers that are natural, renewable and recyclable products, made from wood grown in sustainable forests. In the manufacturing process of our books, and to further support our policy, preference is given to printers that have FSC and PEFC Chain of Custody certification. The FSC and/or PEFC logos will appear on those books where full certification has been granted to the printer concerned.

Typeset by Techset Composition Ltd., Salisbury, UK.

Printed and bound in Great Britain by Short Run Press Ltd. 
We shall one day learn to supersede politics by education.

Ralph Waldo Emerson, 1860 


\section{Contents}

Foreword: English Fissions in Iran ix

Preface xiii

Introduction 1

The Context 1

The Theoretical Debate 6

$\begin{array}{ll}\text { The Framework } & 7\end{array}$

The Purpose $\quad 13$

The Design 14

The Organization $\quad 15$

Part 1: Theoretical and Historical Perspectives 21

1 The Politics of Educational Transfers: Process, Causes and Agents 23

National Forces and Educational Transfers 23

Subnational Forces and Educational Transfers 29

Supranational Forces and Educational Transfers $\quad 33$

Conclusion $\quad 38$

2 The History of English in Iran (1836-1979) 40

English Under the Qajar Dynasty (1836-1925) 40

English Under the Pahlavis (1925-1979) 48

Conclusion $\quad 58$

Part 2: English in Post-Revolutionary Iran (1979-Present) 63

3 The Revolutionary Period (1979-1988) 65

Introduction $\quad 65$

Education and the Indigenization Movement $\quad 66$

Resisting Linguistic Imperialism $\quad 71$

Marginalization of Subnational Forces $\quad 79$ 
The West, an Implicit Reference Society $\quad 80$ Conclusion $\quad 84$

4 The Period of Reconstruction and Privatization (1989-1997) 89 Introduction $\quad 89$

The World Bank, a Reference Society 91 Implications of Policy Privatization Upon Education $\quad 92$ English in the Period of Reconstruction and Privatization 94 Private English Language Institutes, Agents of Internationalization $\quad 102$

Conclusion 106

5 The Period of Global Outlook (1997-2005) 110

Introduction 110

Partnership With Transnational Organizations 112

Transnational Education Model Production and the Expansion of English

The British Council, Another Reference Society 119

The Rise of Professional/Elite ELT Networks 124

The Expansion of Private Language Institutes 127

Conclusion 133

6 Returning to Revolutionary Roots (2005-Present) 136

Introduction 136

Education and the Re-indigenization Movement 137

Unfavorable Attitudes Towards the British Council 140

Unfavorable Attitudes Towards International Publishers 143

Private Language Institutes: Unfavorable Policies and Responses 144

Subtle Opposition at Universities 148

English Departments and ELT Materials $\quad 150$

Low Research Output 151

State Ambivalence Towards English 156

Conclusion 158

7 Forces From Above, Forces From Below 160

Introduction $\quad 160$

Forces From Above 161

Forces From Below 164

$\begin{array}{ll}\text { Appendix } & 167\end{array}$

References 172

$\begin{array}{ll}\text { Index } & 184\end{array}$ 


\section{Foreword: English Fissions in Iran}

The expanding role that English, and English education, has played in the world has received much scholarly attention. Despite the critical work on the impact of English on local people, cultures and languages, spearheaded by Robert Phillipson and Tove Skutnabb-Kangas, English continues to make inroads and to gain speakers. Globalization and its neo-liberal economic policies have spread English even further, but there has been resistance to these forces not only from individuals and groups, but also from entire nationstates. One of the most prevalent cases of countering global forces and Westernized versions of modernity and development today is the Islamic Republic of Iran (IRI), the subject of Maryam Borjian's book.

This book studies the role that English has played in the modern history of Iran, and of the linguistic flows that have accompanied moves towards indigenization to internalization and back again. Although the focus is on the role that English has played in Iranian history, its contribution here goes beyond English and Iran. Blending scholarship on sociolinguistics and critical applied linguistics, but also on comparative education and educational policy, this multidisciplinary study delivers a broad treatment of the role that English and English education play in the life of Iran. The focus is not solely on language and education, but the multi-level analysis is grounded in the political economy of the context.

The organization of the book into Iranian historical periods makes it evident that positions on language education shift according to political motives. Sometimes those reasons have to do with sociopolitical and economic changes in the country itself, while at other times they have to do with external forces that impinge on the country's evaluation of its own performance. The author's multi-level analysis also makes it apparent that historical periods are not monolithic, and that supranational, subnational and national forces interact and are often in tension, even within one historical period. That is, individuals have agency to accept, resist or negotiate policies. Finally, within each historical period there are different flows that have to do with the stage of the language 
education policy. The initial discourse is frequently in tension with the action and implementation, which is often negotiated and adapted as it unfolds.

The concept of agency is an important part of this book's analysis. Whereas other critical sociolinguists treat non-English speaking spheres as helpless in their moves towards internalization and English, this study places agency both within international agencies and local recipients. The author does so by working within a borrowing and lending framework, making sure that readers understand that language education policy is borrowed as well as lent, and that both those who borrow as well as those who lend are acting on their desires and agency. Contexts that borrow language education policy are not blindly emulating; instead, they're often acting on their wishes. Lenders of education policy do not always do so through plain penetration; there is also cooperation and collaboration from the borrowing context.

Borjian makes it clear in this book that, although international finance organizations such as the World Bank and the IMF have much to do with the spread of English language education policies throughout the world, local actors have also been involved. In the case of Iran, the ELT professional networks are active in such an endeavor.

The rise and fall of English language teaching in Iran corresponds to different historical periods. However, despite expectations that English language teaching would have been curtailed in post-revolutionary Iran, Borjian shows how this is not necessarily so. The importance of language teaching within an Islamic ideology is emphasized by the founding father of the IRI, Ayatollah Khomeini himself. Although Khomeini closed down schools owned by foreigners and expelled foreign teachers, he also ordered a state publishing house that would produce homegrown material in English. And as he said in one of his speeches, he even emphasized that, today, learning a foreign language is necessary.

The result of all these complex and frequent ebbs and flows with regard to English language education in Iran is that indigenized English, as well as Anglo-Americanized English, co-exist in Iran today. The author does not accept simple dichotomous explanations - those who defend English language education as important for modernity and development, as well as those who object to it on the grounds that it reflects linguistic imperialism and the power of exogenous forces. The author is persuasive in her argument that English teaching, like all other aspects of education today, is involved in the complex process of educational borrowing and lending.

Just as this book is about English education, although multidisciplinary, it is not solely about Iran. The author makes use of her vast understanding of English language education in Africa and Asia to offer a comparative perspective. And yet, what makes this book so unique is precisely that it 
enlightens us about a context that we know so little about, and uses it to examine the many assumptions that we have had in the global English debate. Borjian can do so because she understands the theories and claims made by scholars who have studied the presence and teaching of English in Asia and Africa, but as an Iranian American she also has deep connections to Iran. The result is a complex treatment of global English and its teaching which takes us beyond the spaces and contexts where we feel comfortable, across a curtain of understandings about religion, culture and language that we rarely cross, through the flows of time and politics that make the study of language an index of humanity itself.

Ofelia García Graduate Center, City University of New York 


\section{Preface}

Wandering between two worlds...

With nowhere yet to rest my head

Like these, on earth I wait forlorn.

Matthew Arnold, 'Stanzas from the Grande Chartreuse', 1855

This book is the story of English, the language of the 'enemies', the United States of America, a.k.a. 'the Great Satan', and its closest ally, the United Kingdom, in post-revolutionary Iran or what has become known as the 'Islamic Republic' of Iran (IRI) following the 1979 Iranian Revolution. It is primarily based on the data I collected through a year of fieldwork (2007-2008) in Tehran. The preface intends to provide an account of the internal and external circumstances of the country at the time of my fieldwork as well as the fieldwork dilemmas I encountered while collecting data in the field.

When I left New York City for Tehran in late August 2007 for the purpose of data collection, there was hardly any trace left anywhere in the country of the principles of 'freedom of expression', 'tolerance', 'respect for diversity' and having a 'dialogue among civilizations' - values that had been advocated, at least at the discourse level, by the previous reformist president, Mohammad Khatami and his administration, during the reform phase (1997-2005) of the IRI in the country. In fact, since August 2005, with the ascendancy of Mahmoud Ahmadinejad to the presidency, it seemed that such liberal values have faded away and been replaced by profoundly antiWestern and ideopolitical sentiments, and the aspiration for 'the revival of the early revolutionary values', which meant, among many things, combating the 'Western cultural invasion'. The intensity of antagonism towards the West - the United States, in particular - seemed to be like that of the early years of the 1979 Revolution. The country's politicians were constantly concerned about the invisible traces of a 'velvet/soft revolution' within the nation, which was said to be supported by 'external forces', having their 
roots in the West. Within such a climate, the country's mass media, all state run, continuously accused the United States and its Western allies of supporting the local grassroots opposition to overthrow the Islamic government in Iran. There seemed to be a profound suspicion and distrust towards outsiders on the part of the country's politicians. Three Iranian American scholars had been arrested just prior to my arrival into the country, who were accused of being involved in backing the so-called 'velvet revolution'. On the other hand, reports produced by non-government, underground local agencies or individuals as well as those of the outside world ${ }^{1}$ depicted a different reality, arguing that the Islamic authorities in Iran tightly watched and monitored pro-reform students and activists in women's and labor movements; activists and journalists were arrested daily and newspapers and magazines were shut down one after another.

Outside its political borders, Iran was at the center stage of a heated debate. The United States under the presidency of George W. Bush together with its Western allies had accused Tehran of seeking to build atomic bombs ${ }^{2}$ and backed efforts for a third round of United Nations (UN) sanctions to punish Iran for not stopping sensitive nuclear work. Iran, on the other hand, insisted on the peaceful nature of its nuclear development and proposed no plan to stop it. China and Russia, close allies of Iran, backed efforts for a diplomatic strategy to end the nuclear quarrel, as opposed to a military solution. ${ }^{3}$ Since then, the matter has not been resolved and it is still at the center stage of political debates among world leaders and politicians.

Within such a climate, my gender was another challenge. As a female researcher, I had more dilemmas to face in Iran than a male colleague. Based on the Islamic Sharia laws of the nation, enacted following the inception of the IRI in 1979, a woman is not allowed to stay in a hotel unless she is accompanied by a mahram - a brother, father, husband or biological teenage son. I did not have the luxury of being accompanied by any mahram, so I had to base myself in one city. Tehran was the chosen city both for its cosmopolitan character and for the enormous opportunity it could offer for data collection purposes. Tehran was home to many universities of different rank, private and state run, as well as being the main base for the headquarters of all types of private English language institutions. It was also the base for all the governmental agencies, organizations and ministries, and the headquarters of various international organizations. Hence, I based myself in Tehran, where I lived in an apartment in its northern part, Shemirān, sitting on the foothills of the Alborz range, covered with never-melting snow for the good part of the four seasons.

Apart from my gender, my nationality (Iranian American) was yet another problem, as too, was my affiliation with Columbia - the university 
in which President Mahmoud Ahmadinejad was harshly criticized or, as some may argue, insulted, by Joseph Bollinger, the president of the University, while giving a public talk at the campus in October 2007, just few months after my arrival in the country. In addition, my research topic was equally problematic. What topic could possibly be more alarming than unraveling the story of English, the language's 'exploration', 'hegemony', 'arrogance' and, above all, 'enemies' in the Islamic land of Iran? The sensitivity of my research topic was coupled with the problematic source of my research funding. I was being funded by the Office of Policy and Research at Teachers College, Columbia University, a source of funding that one would not want to boast about while collecting data in Iran, where some politicians hold a firm position that the majority of Western universities and institutions are on a secret mission to gather data to be used eventually against the Islamic government in Iran - a claim whose accuracy or fallacy I cannot comment on. Yet, all I knew at the time was that Columbia University, to which I was then affiliated, was at the top of the red list of foreign institutions with socalled 'ulterior motives'.

Hence, one can imagine the difficulty I experienced in answering the questions like the ones below, while in the field, trying to gain entry to a state-run research site targeted for inclusion in my research:

Who are you?

What are you doing here?

Who is funding you?

Who will benefit from your research? ...

Following Bernard's (2006) and LeCompte and Preissle's (1993) suggestions, I went into the field with plenty of documentation about myself, my research project, formal letters of introduction and various sets of consent forms for research participants and their rights, drafted along the guidelines of the Institutional Review Board (IRB). I did my best to be honest and consistent in answering the given questions. Yet in spite of all my transparency, I was not granted entry to most state-run institutions. It took me a few months to learn about the 'who is who' and 'what is where' in Iran with regard to official archives and documents. Soon I found myself in a 'fieldwork in archive' situation - using Caroline Brettell's (1998) suggested term - as the data needed to understand the IRI policies towards English were heavily drawn from archival documents, official reports and official laws and regulations, most of them available on the internet on the official websites of the ministries and other state-run institutions. Access to official documents online was partly possible due to the enactment of policies outlined in the country's 
Third Development Plan 2000-2005, in which Mohammad Khatami, the previous president of the IRI (1997-2005), made the Iranian government accountable for the expansion of a digital environment within state-run organizations. ${ }^{4}$ Such convenient diachronic and synchronic access to laws, regulations, reports and official legal documents was advantageous in several ways as it reduced the necessity of being physically present at research sites, facilitated the historical dimension of the topic under investigation and, above all, allowed the study of politically 'hot' topics via archival sources without the intervention of authorities.

In addition to the IRI state, I wanted to examine the role of supranational forces (forces that operate above the nation-state level), in order to identify their contributions to English education in post-revolutionary Iran. Prior to the data collection phase, I had thought that no trace of influence of any supranational forces, most particularly forces from the West, could be found in the post-revolutionary Iranian education system. This presumption was natural given the profound antagonism to the West on the part of the country's politicians. My fieldwork proved otherwise. I began to doubt the validity of my initial conjectures as I identified various transnational organizations as transnational partners of the IRI, with headquarters in Iran. The most notable ones were the World Bank, the UN and its various developmental agencies, and the British Council. Gaining the trust of the members of such organizations was equally a challenge, as these organizations, according to the comments of an employee of one of them, 'were working under a raider situation' - under the threat of being raided by the Iranian authorities. Members of such organizations seemed to be cautious about making contact with strangers, Iranian or otherwise, or making any remarks that could be viewed as being critical of the government. Hence, I had to rely on my local ties to gain entry into these institutions - a strategy that proved not to be fruitful on many occasions. Thanks to various reports written by these international organizations on aspects of Iran's long-term developmental plans and goals, including its education system, I was able to complement my field notes with written official reports and documents.

Universities, private language institutes and the private publishing press were other research sites targeted for inclusion. Their inclusion was intended to examine the contribution of subnational forces (forces that operate below the nation-state level) to the field of English education in post-revolutionary Iran. In addition, it was meant to identify any disparity between 'policy discourse' and 'policy implementation' (or what the national policy documents said at the time and what was actually being taught and practiced on the ground). In order to gain entry into the research site universities, I first tried to approach the president or provost of each university. The attitude of 
these officials was as negative as those of the state-run organizations. In a change of tactics, I started to go directly to the English department in each university and to speak directly to the chairperson of each department. This strategy paid off and I managed to conduct fieldwork in several universities. Gaining entry into private English language institutes and the private press posed no challenge. Nearly all the directors of such institutes, although slightly cautious, welcomed me with open arms.

Here I should like to take the opportunity to thank the many English professors, teachers, students and directors of private English language institutes, the directors of the private publishing press and the few employees of both national and international organizations in Iran, among many others, who kindly agreed to participate in this research and enthusiastically supported me throughout the fieldwork phase, regardless of potential harm. To them, who shall regretfully remain anonymous, I owe a significant debt of gratitude.

This book is also the product of my many interactions - too many, in fact, to acknowledge here - with the faculty members of the Department of International and Comparative Education during my memorable years of doctoral studies at Teachers College, Columbia University. None of these has been more important than Professor Ofelia Garcia, who expanded my academic horizons beyond classroom education to include a multilingual, multicultural, global and critical dimension toward the politics and economics of language education studies. She also initiated me into the world of publishing, for which I am thankful to her. I am also grateful to Professor Gita Steiner-Khamsi for bringing the policy dimension of educational transfers to my attention. The theoretical framework of this manuscript is partly drawn upon her and her colleagues' works. Last but not least, I am thankful to the Office of Policy and Research (OPR) at Teachers College for considering this project worthy of funding support.

Here in my new academic home at Rutgers, the State University of New Jersey, the faculty members at the Department of African, Middle Eastern, and South Asian Languages and Literatures have been generous in making it possible for me to complete this manuscript. In particular, I would like to thank the department Chair, Professor Alamin Mazrui, for considering this project to be worthy of his support. I would also like to thank my research assistant, Michael Zamzam, for his help in preparing the book's index.

I feel flattered and honored to become an author at Multilingual Matters, in its series on New Perspectives on Language and Education, in particular. At Multilingual Matters my thanks are due to several key individuals: Viv Edwards, NPLE series editor for her insightful comments, thought-provoking questions and meticulous editing; Tommi Grover, publisher, for his support 
of this project from the very beginning, and Sarah Williams, Production Manager and her team for help with the editing and production of this book.

And lastly, I owe a monumental debt to my family, to my parents, in particular, who were instrumental in my education and intellectual growth. I am equally thankful to my husband, Dr Habib Borjian, whose inspiration and constructive feedback were indispensable to the project from its very outset. His scholarly input can be seen throughout this manuscript.

Maryam Borjian New York City

\section{Notes}

(1) For more information on the internal situation of Iran at the time of the fieldwork (2007-2008), see BBC News, 2007; Inside Iran, 2007; NBC News, 2004; Vick, 2005.

(2) The best illustration of the tension between the United States and Iran at the time could perhaps be the remarks made by the two countries' politicians about one another. 'This [Iran] is a very dangerous state with very dangerous policies and we need the help and support and intensify efforts of the international community to deal with Iran' (Condoleezza Rice, US Secretary of State; quoted in Rice, 2007). 'They [the US] cannot hurt us, not that they don't want to but because they are incapable of doing so as they are in a difficult situation' (Mahmoud Ahmadinejad, Iran President; quoted in Ahmadinejad, 2007).

(3) For more on the external situation of Iran since 2005, see BBC News, 2005; Deghanpisheh, 2007; NBC News, 2007; Reuters, 2007.

(4) To achieve this policy goal, a special plan called TAKFA (Iran's Applied Development of Information and Communication Technology Plan) was passed in 2002, which made the state-run organization responsible for preserving their laws, regulations, legal documents and official reports in digital libraries (Ansari, 2005). 


\title{
Introduction
}

\author{
What we caught we threw away, \\ What we could not catch we kept. \\ Anonymous, ancient-16th century; \\ cited in Edd Wheeler, 1994: 100
}

\section{The Context}

Post-revolutionary Iran was envisioned with a homegrown, indigenized model of English education - an indigenized English free from the influence of the English-speaking nations. The indigenization movement began some 30 years ago at the onset of the 1979 Iranian Revolution, which put an end to the country's 2500-year-old monarchy (shähanshähi) and replaced it with an Islamic Republic or the governance of religious jurisprudence (velayyat-e faqih) - generally understood as a historical reversal of the modernist direction the country had taken since the Constitutional Revolution of 1906.

The Iranian Revolution of 1978-1979 was a revolution in which most Iranians took part, from students, to professors, intellectuals, leftists, liberals, radicals, religious conservatives and fundamentalists, to women - the same women who were said to have been emancipated from the 'orthodox' Sharia laws by Mohammad Reza Shah Pahlavi, the very Shah against whom they were revolting. Those who were nationalists and liberals thought the revolution would revitalize the underlying principles of the country's 1906 Constitutional Revolution, in which their grandparents and great-grandparents had taken part. And those who were socialists and communists - most Iranian intellectuals at the time - thought the revolution would bring about a 'just' society, in which there would be no class differentiations, oppression, capitalism or mass consumption and, above all, an end to inequality between the poor and the rich. Religious fundamentalists hoped the revolution would revitalize the Islamic laws within a nation that they believed had been 
weakened by modernization efforts under the Pahlavis. On 1 April 1979, Iranians - from all political and ideological fractions and groups - participated in a national referendum in which only one choice was offered (Islamic Republic: Yes or No). Based on the official report of the IRI government, 98\% voted Yes for the Islamic Republic.

The Iranian Revolution and the founding of the IRI under the leadership of Ayatollah Khomeini in 1979 was warmly welcomed by many critical scholars in the West; the most notable among them might perhaps be Michel Foucault, the renowned French philosopher and literary critic. Between 1978 and 1979, Foucault traveled to Iran and wrote a series of articles for the Italian daily, Corriere della sera, in which he not only expressed his central ideas about politics but also analyzed the Iranian Revolution and the positive steps taken by the revolutionary Iranians to create a new form of 'political spirituality', which in Foucault's view was to be a counter-discourse to the thoroughly materialistic discourse dominating the world at the time (Afary \& Anderson, 2005).

The founding of the IRI marked the beginning of a new era in the country's political landscape. Iran, which had been under the geopolitical influence of the West since the early 19th century, turned away from its Western allies, and the United States in particular, to follow an anti-Western, anti-imperialist ideology. The dream was to achieve 'self-reliance' and 'self-sufficiency', not only from the capitalist West, but also from the communist East - the two systems that had polarized the world during the long course of the Cold War. Blaming his predecessors, Reza Shah and Mohammad Reza Shah Pahlavi, for the country's excessive modernization and thus Westernization, and blaming the country's intellectuals for their excessive loyalties to socialism and communism, Ayatollah Khomeini called for the indigenization and Islamization of the country.

Our problems and miseries are caused by losing ourselves. In Iran until something has a Western name it is not accepted... The material woven in our factories must have something in the Latin script in its sleeve edges.... Our writers and intellectuals are also 'Westoxicated' and so are we.... We forget our own phrases and the word itself. Easterners have completely forgotten their honor. ... As long as you do not put aside these imitations, you cannot be a human being and independent. (Ayatollah Khomeini, in a 1979 speech; quoted in Fischer, 1983: 168)

The goal was to craft an indigenized, localized and homegrown model of 'development' - a model in which development was no longer perceived as the 'linear stages' of economic growth, through which all nations had to pass fairly linearly to follow the already proven path of the 'developed' nations in order to achieve 'development'. ${ }^{1}$ Rather, the revolutionary aspiration was to 
break away from Western-driven conventional wisdom and grand narratives to propose a new model for progress and growth, along the lines of the Islamic doctrine. Such a model was intended not only for local use, but also as an alternative to be exported to other developing nations; in the words of the grand revolutionary motto of the time, it was to be an Islamic Republic 'self-sufficient' (kod-kafā) from the West and the East (na sharqi, na gharbi).

This new concept of 'development' was not, however, viewed only as an economic construct, but was broad enough to include culture and the vast domain of cultural interactions within society. Thus the state was equally determined to craft a new cultural identity for its citizens: an identity entirely drawn upon Islam and its grand narratives for truth, morality, humanity, existence, and for all other aspects of public and private life; an identity that has come to be regarded as the 'only truth' or, as some may argue, the 'Absolute truth', aiming to replace all other types of 'truths' constructed by all other 'isms' from within or without - capitalism, socialism, liberalism, rationalism, modernism, secularism and, above all, nationalism. The latter was said to be a product of the West, which had been crafted, promoted and disseminated in Iran by the Pahlavi regime, "the foe of the people and friend of the enemies', despite numerous pieces of historical evidence showing that Iran was among the few nations that had entered the age of 19 th century nation building and nationalism with a longstanding legacy of historical and cultural consciousness of its past - its pre-Islamic past, in particular $^{2}$ (Ashraf, 2006; Fishman, 1969). Abandoning nationalism in favor of an illusionary religious internationalism, starting in 1979, Iran has been re-placed within the melting pot of the Islamic Umma ['nation' or 'community' in Arabic], in order to be part of the greater whole - to be an entity in which the nation's particularity had to be merged with the general communality of the larger Islamic world for better or for worse.

The drive towards 'localization' and 'indigenization' became a policy as soon as the newly established government undertook its massive Cultural Revolution (1980-1982), whose two underlying pillars of 'Islamization' and 'purification' regulated and institutionalized the newly constructed ideopolitical and religious discourse for the nation. Those who were perceived to be 'unfit' citizens were said to be imprisoned, eliminated, purged or forced to escape the country to live in exile (Ashraf, 1997; Fischer, 1983; Habibi, 1989; Mehran, 1997; Sobhe, 1982). Education was the principal means for the dissemination of the state's newly constructed identity with its grand narratives of the 'Islamic truth', and school children were the first to be targeted with the internalization of the 'truth'. This is what Hisham Sharabi, the distinguished Palestinian intellectual and literary critic, regards as the 'repression of the individual from childhood'. 
If society is afraid of creativity and considers innovative forces a threat to its traditions and its heritage, it resorts to every means available to put an end to it, the most successful means being repression of the individual from childhood - as thereby shackling him intellectually and psychologically as an adult. How many Shakespeares, an Einstein, or a Marx has our society killed before the child reached its adolescence? (Sharabi, 2008: 100)

Within such a climate, the attitude towards foreign languages was profoundly negative. Foreign languages, meaning European languages, were treated as 'suspicious subject matters', 'the enemies of the people' and the main means of the imperial powers to practice their 'cultural and linguistic imperialism', 'hegemony' and 'arrogance' upon Third World nations, Muslim countries in particular. Among foreign languages, English was considered the most unfortunate as it was closely associated with the United States - or the 'Great Satan' as it has been referred to in the political discourse of Iran since 1979. The intensity of hostility towards the West and to European languages could perhaps be best explained by the closure of the Iran-America Society (Anjoman-e Irān o Amrikā) and the British Council (Anjoman-e Irān o Engelis), the most active centers of English language teaching (ELT) in pre-revolutionary Iran. In keeping out the foreign cultural values and elements of English, Iranian politicians of the post-revolution followed in the exact footsteps of their predecessors in post-revolutionary Cuba (Corona \& Garcia, 1996), China (Bianco et al., 2009) and Russia (Ter-Minasova, 2005) to eliminate all variables associated with so-called 'cultural' and 'linguistic' imperialism. Thus, all foreign language schools were shut down one after another, including those teaching French and German. All foreign teachers and professors, the majority of them Americans, were expelled from the country. Soon, at the order of Ayatollah Khomeini, a state-run publishing house, aka SAMT, ${ }^{3}$ was established to produce indigenized, homegrown textbooks for local use.

Indigenized textbooks were needed because English textbooks of the pre-revolutionary era were Anglo-American in content, and thus were a site of interaction and dialogue between the natives and non-natives - between 'Muslim' Iranian non-native English speakers of Persian, who were said to have long been alienated from their 'true' past, on the one hand, and their Christian American or British counterparts, native speakers of English, whose names were often 'Jack', 'Joe', 'John', 'Mary', 'Catherine' or 'Elisabeth' in pre-revolutionary school textbooks. Such a site of interaction and dialogues had to be revisited and appropriated, and thus was a natural target for 'indigenization' and so-called 'liberalization' from 'unwanted' foreign influences. As such, some aspects of English were selectively 
accepted (phonology, morphology and syntax), whereas the cultural elements of the language were all removed for fear of being a threat to the nation's 'tradition'. As a result, Jack, Joe, John, Mary, Catherine and Elisabeth all disappeared from school English textbooks and were replaced by new characters whose names were Mohamed, Ali, Fatima, etc., all pious Muslims, who dressed modestly, visited mosques regularly and read the Koran daily. They all had one goal in common: to learn English - the language of hegemony, arrogance and exploitation - only to empower the nation in its new stage of bottom-up, localized, indigenized modernity and development. As a result, a new form of English was born, a form that some may regard as a 'flat, lifeless and context-free language', which has been taught to generations of school children via the state's approved homegrown English textbooks ever since.

The indigenization of English in Iran caught the attention of scholars across academic disciplines in the West, especially those from the critical wing, who had long been skeptical of the worldwide domination of the English language. In 1991, James Tollefson, from the field of English language and literature, commented on the localization of English in post-revolutionary Iran in that way:

The end of English domination was associated with the changing structure of power in Iranian society. By breaking economic, military, and industrial ties with the United States, post-revolutionary Iran dramatically reduced the need for English teachers. It nationalized its own cultural symbols and rhetoric, defined for itself what is 'Iranian' and what is 'foreign', and eliminated many mechanisms for the spread of Western culture and language. (Tollefson, 1991: 91)

The indigenization movement, together with anti-Western and antiimperialist sentiments, has continued to dominate the political and educational discourse of post-revolutionary Iran for the better part of the past three decades. But contrary to what might have been expected, as this book intends to show, the pre-revolutionary American and British pals of English textbooks - the Jacks, Joes, Johns, Marys, Catherines and Elisabeths - seem not have been fully erased from the memory of Iranians, two-thirds of whom are currently under 30 years old. These are the children of the revolution, who grew up in Iran under the Islamic Republic and attended postrevolutionary schools, in which their minds were in the care of the authorities to be filled with whatever the state deemed 'appropriate'. Yet this very generation now displays a profound desire for the outside world. They are interested in learning about the 'good old days' of Jack and Mary's grandchildren and great-grandchildren, to see what they do, where they live, where they go 
to school, what hobbies they have or what games they play in the global, borderless, market- and information-driven world of the 21st century.

As a result, despite the state's 30-year-long constant efforts, the existing system of English education in Iran is not entirely indigenized. Rather, it is marked by two diverging forms of English: (1) the indigenized model that is used by the state-run education programs, and (2) the internationalized or Anglo-Americanized model, which is used by private-run education programs throughout the nation. The latter model is the one currently in vogue and most demanded by Iranians.

\section{The Theoretical Debate}

Variety is more than the spice of life; it is largely of its essence. John Dewey; cited in Archambault, 1964: 85

Over the past two decades, the discourse of ELT has become more homogeneous around the world. From Latin America to Europe, Africa and Asia, English teachers, practitioners, consultants and even policymakers often share similar insights into what constitutes 'best' ELT pedagogical practice. Terms such as 'student-centered learning', ${ }^{4}$ 'communicative language teaching'5 (CLT), 'task-based instruction', 6 'authentic materials', 7 among many others, are becoming part of the everyday discourse of English language teachers around the world. If one closely examines the discourse of ELT educational reform movements, one would realize that the descriptions of problems and the proposals for solutions are more or less identical, regardless of the boundaries of space. Almost all nations, regardless of their socioeconomic status, are deeply involved in upgrading and/or remodeling their former largely structured and drill-based English curricula with communicative and task-based ones. The aim is to produce the kind of interactive and productive English required for new generations of the workforce in the economically borderless world of today. ${ }^{8}$ The question as to whether these ELT models/standards are randomly diffused or systematically disseminated has triggered controversial responses on the part of scholars across the various fields and sub-fields of educational linguistics.

From a normative perspective, also labeled as 'liberal idealism' and/or 'celebratory conservativism' by Pennycook (2001), English is the language of modernity, development and prosperity. It facilitates access to global research, science and technology and promotes modernization and participation in global commerce. In response to the question as to the cause of the global diffusion of ELT models and standards, the proponents of this view either adopt 
an apolitical view, arguing that the true domain of English language education is applied linguistics, which is the intersection between language teachers and linguistics, but not social science, or merely attribute the prevalence of such methods to the will and desire of local borrowers who, in their quest for modernity, development and economic progress, enthusiastically borrow these models from the English-speaking West and implement them locally without any hesitation (Barber, 1993; Crystal, 1997; Graddol, 2010; McArthur, 1998).

From a critical perspective, the discourse of the global dissemination of ELT models, as presented by a normative yardstick, is fundamentally flawed because it does not take into account the role of power and hegemony, not to mention colonialism and imperialism, in diffusing the so-called 'global' ELT norms and standards from the English-speaking West to other parts of the world. Drawing upon the notions of 'center-periphery', these scholars often attribute the global prevalence of ELT models to exogenous forces, arguing that the trajectory of global ELT practices, like the dissemination of global English, involves a one-way flow of knowledge from the center to the periphery. And so it is creating world hegemony, keeping the less developed nations dependent on the technology, commerce and research production of the West, particularly the English-speaking West (Cameron, 2002; Holliday, 1994; Pennycook, 1998; Phillipson, 1992; Phillipson \& Skutnabb-Kangas, 1994; Tollefson, 2000).

Others, who take a 'postmodern' stance, draw upon Foucault's (1972) definition of 'truth-knowledge-power', arguing that 'truth' is illusive and subjective, constructed and naturalized through the 'discourse' by the will of 'power'. Hence, these scholars either deconstruct the discourse of English pedagogy in order to unravel its hidden agendas (Pennycook, 2004) or use the notion of 'linguistic hybridity' as a springboard to assign agency on the part of local borrowers (Brutt-Griffler, 2002; Mazrui, 2004; Peirce, 1989; Warschauer, 2000), or to explore how imported ELT practices get resisted and/or adapted locally to confirm the existence of national and regional variations among ELT practices around the world (Canagarajah, 1999, 2005a).

\section{The Framework}

Language moves through time. But time itself is filled with actors, voices, moments of crisis, conflict and eloquent articulation; and power defines both the input and the output of the processes we can observe.

Jan Blommaert, 2010: 138

The globalization of certain education models and standards has been discussed extensively not only by the educational linguists of TESOL and 
applied linguistics but also by scholars from a variety of disciplines including bi/multilingual education, sociology of language, comparative and international education and education policy studies, among others, resulting in a rich body of literature that contributes to our understanding of language and globalization as well as the educational convergence-divergence debate from both a micro and macro dimension.

For Ofelia Garcia (2009), a strong proponent of bi/multilingualism, language policies and practices in the 21st century are like South Asian banyan trees: they 'grow up, out, down, horizontally or vertically through the air until they come upon something solid' (Garcia, 2009: 8). She uses this analogy to reflect upon the complexity of forces involved in shaping educational language policy practice outcomes in the global era.

For Jan Blommaert (2010), from the field of macro sociolinguistics or sociology of language, globalization is a historical process; its outcomes, however, can only be observed synchronically: 'A historical process such as globalization can only be observed synchronically. We can only witness the synchronic outcome of historical processes.' As such, his suggestion is to apply new concepts and tools that "allow us to "read back" from the synchronic manifestations towards the processes that produce them' (Blommaert, 2010: 138).

In a similar vein, for Gita Steiner-Khamsi and Stolpe (2006), from the field of comparative and international education, globalization may capture, in a very broad sense, why educational reforms in different parts of the world are becoming strikingly similar, what is known as 'educational convergence'.9 Yet 'this trendy characterization', as they argue, 'suffers from many shortcomings; among other deficiencies, it is devoid of agency, process, and rationale' (Steiner-Khamsi \& Stolpe, 2006: 1).

This book draws upon the contributions of various disciplines - educational linguistics with its various sub-fields, comparative and international education, and education policy studies, in particular - to offer a new perspective on the literature on global English, in which a new analytical devise is offered to explore the globalization of ELT models and standards through a multilevel analysis lens (both vertical and horizontal). In particular, its interest lies in understanding the agents (who), process (how and what), and rationale or causes (why) of ELT-related educational imports and exports. This approach is in line with the emerging literature in the field of educational linguistics, in which scholars engage increasingly with globalization (Block \& Cameron, 2002; Block et al., 2012; Blommaert, 2010; Canagarajah, 2005b; Garcia, 2009; Pennycook, 2007).

In doing so, we will borrow the concept of 'educational transfer' from the field of comparative and international education ${ }^{10}$ and use it as our main 
unit of analysis. Educational transfer refers to a process in which an education model, such as ELT, is taken from one context and transplanted into another either voluntarily or through coercion. The heart of educational transfer studies is the act of 'externalization' or 'internationalization', which refers to a process in which references are made to educational lessons, ideas, models or standards external to a country (Schriewer, 2003). Such references, as noted by Steiner-Khamsi (2004), could be made either to an imaginary 'international community' (e.g. international standards or norms) or a 'concrete other' (e.g. a particular international organization, such as the British Council, or a particular country, such as the American versus British ELT models). The questions as when, why, how and by whom the global reforms, ideas and knowledge resonate in a local context is the main concern of educational transfer studies, especially those who examine the politics of educational borrowing and lending (Phillips, 2000, 2004; Phillips \& Ochs, 2003; Schriewer, 2000, 2003; Schriewer \& Martinez, 2004; SteinerKhamsi, 2004; Steiner-Khamsi \& Quist, 2000).

The central argument is that educational transfer is a highly complex process, which involves two sides (borrowing and lending), various actors (at the national, subnational and supranational levels), multiple causes (social, political, economic, educational, among others), and multiple stages (policy attraction, implementation, adaptation and internalization, etc.). Researchers who take into account the role of all these variables, as presented in Figure I.1, will certainly make a meaningful contribution to educational transfer

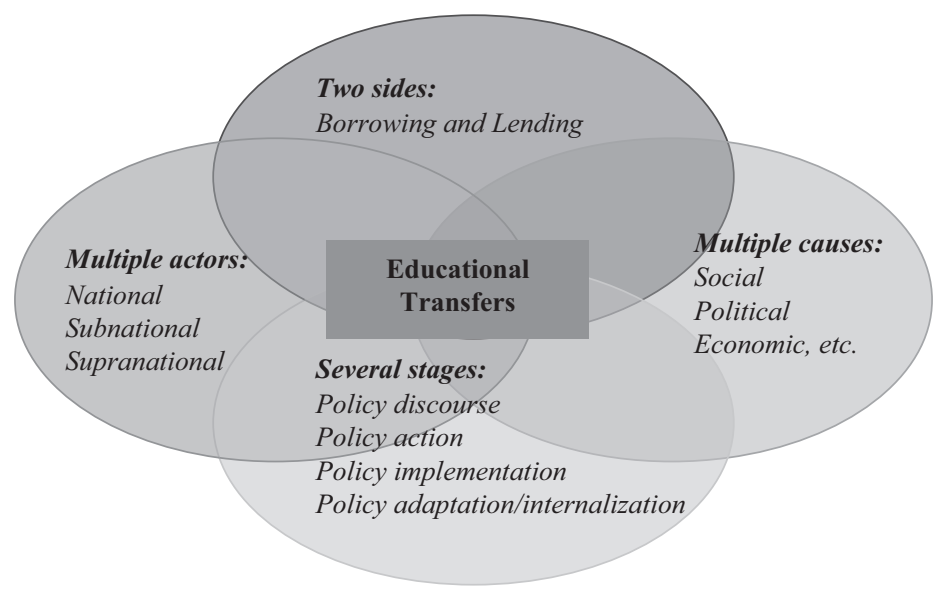

Figure I.1 Structural typology of educational transfers 
studies, as all these variables have an impact on educational transfer as a unit of analysis.

\section{The two sides}

Educational transfers include two sides: borrowing and lending, also known as educational imports and exports. ${ }^{11}$ The term 'borrowing', as defined by David Phillips (2004), who is known for his pioneering research into this subject, covers a whole range of issues relating to how and why a foreign education model is used by policymakers or other local stakeholders to be implemented locally. The term 'lending', on the other hand, refers to a process in which forces external to a country, either an international organization or a particular nation, initiate lending or exporting its education models or standards to another nation. Within this process, the lending institution or nation serves as a 'reference society', i.e. a nation or an international organization, from which education models are either exported or voluntarily borrowed and transplanted into another nation's education system. As the insights of comparative educationalists alert us (SteinerKhamsi \& Quist, 2000), it is important equally to take into account the two sides of the interaction, as any encounter involves two sides; thus agency needs to be acknowledged for both sides - that is, for international lenders and for local recipients/borrowers.

\section{Various actors}

Educational transfers also involve various actors with different motives and interests - actors interacting above, below and at the nation-state level; these should all be taken into account. As argued by Bernard Spolsky (2004), the forces at the national level often interact with less obvious forces occurring at levels below and above the nation-state. Actors who operate above the nation-state level, or what we will call supranational forces throughout this book, are forces exogenous to a country, e.g. multilateral and bilateral donors, international non-governmental organizations (INGOs), transnational organizations, and all those who are not only in the business of lending their financial and technical resources to other nations but also their 'best' educational standards and models. As argued by comparative policy analysts (Bennett, 1991; Howlett \& Ramesh, 1995), it is true that states as autonomous entities have the authority to close their borders against any foreign influences they disapprove of, but in reality constraints rooted in the international systems limit their exploits to a great extent. Thus a nation may accept borrowing or emulating a foreign lesson, standard or model and implement it locally, due to economic, social or political pressures from 
within or without. Subnational forces are the actors who operate below the nation-state level, actors who do not hold governmental authority but use their funds, power and/or collective voices to pull policy outcome, either directly or indirectly, in the directions they desire, e.g. elite networks, professional units, business enterprises, religious entities, etc. National forces are actors who operate at the nation-state level, e.g. politicians and state officials, those who have not only the authority but also the financial resources to make micro and macro policy decisions with regard to the nation's education and to implement or reject the policies they approve or disapprove of.

\section{Multiple causes}

Educational transfers, as eloquently noted by Schriewer and Martinez (2004), do not operate in a vacuum but rather occur for numerous reasons, reasons that correspond directly to the context in which they occur. And so, in order to identify the what, why and how of educational transfer, or what is labeled as the 'socio-logic of externalization' by Schriewer (2003), one cannot decontextualize education, isolating it from its social context; rather, one should search in the deeper social, political, economic, cultural and historical contexts in which educational transfers occur in order to be able to identify the causes of receptiveness or hostility towards foreign lessons and ideas.

\section{Several stages}

Educational transfers also include various stages. The first stage, 'policy discourse', includes all the official talks among the borrowers, the lenders or between the two groups as to why a foreign model should be lent/ exported to or borrowed/imported from elsewhere and implemented in another context. At this stage, there are typically some kinds of stimuli that spark off cross-national attraction in an education model on the part of the borrower, which could be political, economic, etc. Whenever a catalyst exists, it will create the conditions for searching for successful examples of education elsewhere and will cause policymakers to make decisions as to whether or not to look outside for a successful model to emulate. Nonetheless, these decisions are not always realistic or well measured but may include what are labeled as 'quick fix solutions' or 'phony policy' by David Phillips (2004); such decisions are often made in response to internal or external pressures. The second stage, 'policy action', refers to a process in which the decisions as to how to import/export a foreign lesson are made; these decisions are often made by policymakers, from both lending 
and borrowing institutions and nations. The third stage, "policy implementation', involves importing a foreign education model and transplanting it into another. Any foreign model will undergo changes to fit the context. Successful implementation, however, depends on the extent of the promotion of, or resistance to, the new measures. The final stage is called 'adaptation and internalization or indigenization', when the foreign borrowed models get adopted locally to the extent that they are internalized and become part of the local system. At this stage the foreign borrowed model may often not resemble its original version, exported from the lending nation/institution. ${ }^{12}$

Returning to the various sides of the debate about global English research, discussed earlier, we can argue that these perspectives are complementary rather than antagonistic or mutually exclusive. Once we acknowledge the two sides of educational transfers (borrowing and lending) and assign agency equally to both sides (international lenders and local recipients) and take into account the role of various actors operating above, below and at the national-state levels, then the debate as to which set of forces (exogenous or endogenous) is responsible for the globalization of ELT standards, as put forward by the proponents or opponents of any of these approaches, will become minute, if not outdated. Similarly, once we do not decontextualize education from its sociohistorical context and acknowledge the complexity of the process and the multiplicity of causes involved in educational transfers, then holding an apolitical view will be a formidable task, if not impossible; the social, political and economic causes of educational transfers will be so transparent that they will urge us to look beyond education and its sub-field of English education to understand the politics and economics of educational transfers - to which critical scholars have most contributed. Likewise, if we acknowledge the various stages of educational transfers (policy discourse, policy action, implementation, adaptation and internalization), we can surely identify both converging and diverging trends within the field of English worldwide; thus the debate as to whether there is one global model of English education towards which school systems around the world are converging in unison, or there are many Englishes, confirming the existence of national and regional variations, will certainly be less urgent if not unnecessary. Convergence is indeed happening, but perhaps at the policy discourse level in most parts of the world. At the implementation level, all foreign models go through adaptation to fit the local context. That said, the points made by the proponents of each approach are all well considered in this book. Certainly, each one of these approaches sheds light on a different process, agent or cause of educational transfers. 


\section{The Purpose}

Complete isolation is impossible in nature. John Dewey; cited in Archambault, 1964: 9

This book explores the politics of English language teaching and learning in post-revolutionary Iran from 1979 to the present. Post-revolutionary Iran is in a unique position with regard to English education: unlike most nations which enthusiastically borrow ELT practices from the English-speaking West, Iran has turned its back on the Western world and holds to a rigidly antiimperialist ideology alongside indigenization and localization. Conferences and seminars are held regularly glorifying the Islamic past of the country, the languages of Islam and the need to disseminate them in the world. Virtually no action is taken to borrow ELT models and norms from other parts of the world, nor from the Anglo-American language institutions, which are categorically labeled 'Satanic'. Yet, as this book will show, there is a preponderance of global English textbooks, methodologies, standards and norms in Iran. Thus, post-revolutionary Iran, an allegedly isolated nation, offers a unique case for exploring the subtle ways in which the process of borrowing and lending so-called 'global' ELT practices is taking place in a country that defines itself as anti-imperialist and anti-West.

Drawing upon diverse qualitative and quantitative data collected over a year of fieldwork (2007-2008) across various state, private and international organizations in Iran, the book examines the nation's English education at the two levels of policy and practice to explore the process (how and what), causes (why) and agents (who) of the two diverging trends of 'indigenization' and 'internationalization' within the country's English education over the past three decades. Arguing that educational policies are made via a complex process, which involves various forces with different motives and interests - forces operating above, below and at the nation-state levels - the book explores the ways in which English education has been perceived by various stakeholders both at the national level (politicians and policymakers) and at the subnational level (professional associations, university-based and privately based language programs, English professors, teachers and students) and the catalysts that have sparked off receptiveness or hostility towards foreign lessons, ideas and norms on the part of each set of stakeholders.

In particular, it explores the interaction between the forces from above, those in charge of setting the nation's educational policies, and forces from below, those who do not have the power to participate in educational decision-making processes but yet use their voices, funds and power to pull educational outcomes in the direction they desire. Although it is presumed 
that supranational forces have been absent from the realm of English education in post-revolutionary Iran, the book equally takes into account the implicit and explicit contributions of various international and transnational organizations (the World Bank, the UN developmental agencies and the British Council) to the internationalization of the field of English education in the country.

Situating English education within the nation's broader sociopolitical context, the book also explores the intersection and intersectionality of the nation's English education with variables such as power, economy, policies, ideologies and information technology to determine the politics and economics of English teaching and learning in the nation from a macro perspective.

\title{
The Design
}

\author{
I think metaphorically of qualitative research as an intricate fabric \\ composed of minute threads, many colors, different textures, and various \\ blends of material. \\ John Creswell, 2007: 35
}

Scholars across various disciplines have increasingly advocated multilevel analyses in research design and methods, in qualitative research, in particular. Favoring a research design with 'multiple variables', Joshua Fishman et al. (1991), from the field of the sociology of language, states: 'It is easy to be misled and intellectually impoverished by studies that examine only a small handful of variables whereas the circumstances of the real world actually involve very complex interrelationships between much larger numbers of variables' (Fishman et al., 1991: 28). In developing their framework for a 'vertical case study' for comparative and international education studies, Vavrus and Bartlett (2006) suggest research design and methods that 'strive to situate local action and interpretation within a broader cultural and historical, and political investigation' (cited in Bajaj, 2010: 177). In a similar vein, Monisha Bajaj (2010) calls for a 'multilevel analysis' approach in research design in comparative education because 'multilevel approaches can provide important insights into the multiple dimensions of schooling in highly stratified societies for various stakeholders' (Bajaj, 2010: 177). The data presented in this manuscript are in line with these frameworks.

This book is primarily based on the data collected through a year-long fieldwork study (2007-2008), across various public, private and international organizations in Iran. It is a 'chronological' case study, as it covers a time span of three decades (1979-present). It is a 'vertical' case study, as it examines 
educational practices at the two levels of policy and practice as well as at the three levels of the national, subnational and supranational. It is a 'horizontal' case study as it applies a multilevel analysis, going beyond the field of education and its sub-field of English education to include economic and political causes of educational transfers, among many others.

In conducting a chronological, vertical and horizontal case study, various instruments were needed for the purpose of data collection. The research instruments included in-depth fieldwork across various research sites at the national, subnational and supranational levels - sites whose operations were perceived as having a direct or indirect impact upon the country's education and its sub-field of English education. Other means of data collection included document analysis, school and university visits, visits to various publishing houses, and unstructured and semi-structured interviews with various stakeholders, including two ministry officials, three representatives of international organizations operating in Iran, 20 professors of English and 30 students of English.

Although this book draws primarily from qualitative data, these were complemented by quantitative data gathered via two computer-assisted selfadministered electronic surveys, to which 88 professors and 102 students of English responded.

\section{The Organization}

This book consists of two parts: Part 1 (Chapters 1-2) offers a theoretical and historical perspective, whereas Part 2 (Chapters 3-6) provides an account of English education in post-revolutionary Iran.

Chapter 1, The Politics of Educational Transfers, is theoretical in nature. Drawing upon the proposed theoretical framework in the introduction, the chapter applies a multilevel, analytical lens with a threefold vertical-horizontal framework to explore the variables most associated with the process, causes and agents of ELT educational transfers worldwide. The threefold framework explores the role of subnational, national and supranational forces in English educational transfers around the world. This is meant to set the stage for the reader to explore the various instances of ELT educational transfers worldwide before narrowing down the reader's focus onto the case of ELT in Iran.

Chapter 2, The History of English in Iran (1836-1979), is an account of English education in Iran throughout modern times - from the arrival of English via American and British missionaries in 19th century Iran under the Qajar dynasty, to its expansion and promotion by American and British educational programs during the Cold War in 20th century Iran under the 
Pahlavi dynasty. This chapter offers a historical perspective and will serve as a background section to our understanding of English education in postrevolutionary Iran.

An account of English in Post-Revolutionary Iran (1979-Present) is provided in the second part of the book, Chapters 3-6. Chapter 3, The Revolutionary Period (1979-1988), explores the fate of English in Iran during the first decade of IRI rule under the reign of Ayatollah Khomeini, whose projected outlook for the nation was ideological and anti-Western. During this phase, English was perceived as the language of 'the enemy' and its practices were under the absolute supervision of the state. Chapter 4, The Period of Reconstruction and Privatization (1989-1997), examines English education in the post Iran-Iraq War period, during the presidency of Ali-Akbar Hashemi Rafsanjani, whose projected outlook for the nation was more pragmaticutilitarian and less ideological. During this phase English was promoted by private English language institutes, new but powerful educational establishments in post-revolutionary Iran, whose emergence was directly related to the importation of policy privatization into the country - a policy lesson borrowed from the World Bank. Chapter 5, The Period of Global Outlook (19972005), refers to Iran under the presidency of Mohammad Khatami, the reform-minded president of the IRI, whose projected outlook for the country was more global and less ideological. During this time English, the former language of 'the enemy', negotiated a new role for itself in the country and became the 'language of global knowledge, research and technology', entering the country's policy documents and long-term developmental plans. Finally, Chapter 6, Returning to Revolutionary Roots (2005-Present), scrutinizes English education under the presidency of Mahmoud Ahmadinejad, who is generally known for his aspiration for the 'revival of the early revolutionary principles', underpinned by the founding father of the Islamic Republic, Ayatollah Khomeini. Regardless of the state's profound isolation policies, during this phase international English has penetrated the educational domains of Iran to the extent that the government has decided to turn a blind eye to it.

Since the account of English education in post-revolutionary Iran provided throughout these four chapters is closely intertwined with the country's sociohistorical context on the one hand, and its education system on the other, these chapters begin with an Introduction, in which the author sets the stage by providing the reader with an account of the country's social, political and economic context, together with that of its education system. The chapters will end with a conclusion, in which the author provides a summary of the main findings associated with the what, how, why and who of the indigenization or internationalization trends. 
Chapter 7, Forces From Above, Forces From Below, provides a summary of the story of the two Englishes in Iran, while shedding light on the contributions of the forces from above (national and supranational forces) and those from below (subnational forces).

\section{Notes}

(1) One of the leading economic theories of modernization at the time was formulated by W.W. Rostow in his 1960 work, The Stages of Economic Growth: A Non-Communist Manifesto. Rostow argued that economic modernization occurs in five universal stages of growth, from traditional to modern. He believed that countries go through each of these stages in a linear progression, and he outlined the conditions likely to occur at each stage, such as fatalism, investment, consumption, etc. Among the principal implications of Rostow's theory are the concepts of 'universal standards' and development as a 'linear process'. Since the 1960s, these two principles have been taken into account in the establishment of conventional development projects, reinforcing the idea that development can only be achieved if underdeveloped countries copy the already proven examples of the West (for more, see Peet, 1999).

(2) The best illustration could perhaps be the survival of the Persian language following the defeat of the Persian Empire and Zoroastrian religion by Muslim troops in the 7th century AD. This conquest aimed to place Iran within the melting pot of the Islamic World, dominated by Islam and the Arabic language. However, after two centuries of silence, Persian rose from the ashes of defeat with greater brilliance and richness as a potent symbol of Persian cultural identity. This manner of revival and reconstruction was unparalleled among the other ancient cultural areas, such as Mesopotamia (Iraq), Syria and Egypt, which were incorporated into the Islamic world and lost their languages under the hegemony of Arabic. Another illustration could be the versified Iranian national epic of Shäh-nāma (Book of Kings), which ranks with the Indian Mahabharata, the Greek Iliad and Odyssey and the Germanic Nibelungen Saga as one of the great epics of the world. Three centuries after the conquest (c. AD 1010), Ferdowsi produced Shäh-nāma for Iranians, telling of their past prior to the advent of Islam (for further details, see Ashraf, 2006; Borjian \& Borjian, 2011).

(3) The Organization for Researching and Composing University Textbooks in Humanities, known by its acronym, SAMT, was founded in 1985, with the concurrence of Ayatollah Khomeini, for the single purpose of producing homegrown academic textbooks for the country's universities. It was established to minimize the country's need for foreign-produced textbooks. For more on SAMT, see Chapters 3 and 4.

(4) As defined by the Longman Dictionary of Teaching and Applied Linguistics (Richards et al., 1992), student-centered learning refers to a learning situation in which students take part in setting goals and objectives, have more control over what and how they learn and take more responsibility for their own learning. Teachers are seen as helpers and/or counselors.

(5) As its name suggests, CLT favors communication and the authentic use of language over merely mastering linguistic structures such as phonology, morphology and syntax. Modeled on native-speaker norms, CLT emphasizes communication, presupposing that the purpose for learning a language is to prepare learners for engagement in social interaction (Larsen-Freeman, 2000). Linking language with communication has, in turn, led to the emergence of a new dimension in the language-learning 
process, known as the acquisition of 'communicative competence' (Hymes, 1971), i.e. knowing when and how to say what to whom. As a result, a language learner should not only learn the phonological, morphological and syntactic aspects of the target language, but also its sociocultural components. According to Richards and his coauthors (1992), this approach has been developed particularly by British applied linguists as a reaction away from grammar-based approaches.

(6) Task-based language teaching is a sub-branch of CLT, in which the syllabus is organized around 'tasks', rather than in terms of grammar or vocabulary. The use of a variety of different kinds of tasks is assumed to make teaching more productive and interactive - in short, more communicative (Larsen-Freeman, 2000; Richards et al., 1992).

(7) The term 'authenticity' refers to 'the degree to which language teaching materials have the qualities of natural speech or writing. Texts which are taken from newspapers, magazines, etc., and tapes of natural speech taken from ordinary radio or television programmes, etc., are called authentic materials' (Richards et al., 1992: 27). It is noteworthy to say that teaching materials used with a communicative approach are often authentic.

(8) For more on this subject, see Angel Lin and Peter Martin's edited volume (2005).

(9) The questions as whether school systems around the world are converging towards one common point is an old yet controversial question, triggering divergent responses on the part of comparative sociologists and anthropologies. On the one hand, there is the theory of world culture, aka neo-institutionalism, developed in the later 1970s by John Meyer and Francisco Ramirez, comparative sociologists at Stanford University. Based on this theory, not only did the school systems around the world originate from the common source of Europe but they have also become more similar over time (Baker \& LeTendre, 2005; Boli \& Thomas, 1999; Meyer et al., 1977; Ramirez \& Meyer, 2002; Tyack \& Tobin, 1993). Drawing upon their highly quantitative studies, world culture theorists point to educational 'isomorphism', or school similarities across nations, to prove the existence of one 'global culture' of schooling, to which school systems around the world are converging in unison. On the other hand, there are anthropologists such as Anderson-Levitt and her colleagues (2003), whose research has shed light on educational divergence worldwide. Building upon the anthropological notion of culture, anthropologists place emphasis on 'local context' and reflect on how exogenous influences in education have been interpreted differently in various cultural contexts. In this book we will bypass this lively debate because, once one acknowledges the various stages of educational transfers (policy discourse, policy action, implementation and adaptation), we can see both converging and diverging trends within school systems worldwide. Convergence is happening but most likely at the policy discourse level. At the implementation level all foreign models go through adaptation to fit the local context (for more on the latter approach, see Phillips, 2004; Steiner-Khamsi \& Stolpe, 2006).

(10) The concept of 'educational transfer' has long been a source of fascination for scholars across disciplines, although they may often have different research agendas which lead them to examine this concept. For neo-institutionalists, who are merely interested in identifying cross-national educational convergence, educational transfer is used as a springboard to explain why educational systems in various parts of the world are becoming increasingly similar. For anthropologists, this concept is used to explain cross-national educational divergence. Yet for comparative educationalists, especially those who examine the politics and economics of educational borrowing 
and lending, educational transfer is used as a springboard to understand the politics of educational transfers. For more on the latter approach, see Gita Steiner-Khamsi's (2004) edited volume.

(11) Educational borrowing-lending or educational import-export? There has been a debate in the field of comparative education as to which of the two above-mentioned terms should be used while examining educational transfers. In this book, we will bypass the debate and use both terms interchangeably.

(12) For more on the various stages of policy borrowing and lending in the realm of education, see David Phillips (2004) and Gita Steiner-Khamsi (2004). For more on the various stages and process of policy convergence, see Colin Bennett (1991), from the field of comparative policies. 


\section{Part 1}

\section{Theoretical and Historical Perspectives}

The limits of my language are the limits of my world. Ludwig Wittgenstein 


\section{The Politics of Educational Transfers: Process, Causes and Agents}

Language planning involves a constant negotiation of the interests
of different social groups and of the changing priorities of a
community. Rather than treating them as a problem for policy formation,
we should think of tensions as opening up more complex orientations to
language in education.
Suresh Canagarajah, 2005b: 194

This chapter examines the politics of ELT educational transfers around the world in order to identify the most common variables associated with the process (what and how), causes (why) and agents (who) of ELT educational transfers worldwide. It is meant to offer the reader a global perspective, before narrowing down the focus on the politics of educational transfers in post-revolutionary Iran, the subject nation of this book. In doing so, we will propose a threefold framework: national forces and educational transfers, subnational forces and educational transfers, and supranational forces and educational transfers. Through this framework, we will use the multilevel analytical lens proposed in the introduction as a springboard to shed light on various issues surrounding the global import/export of ELT models and standards around the globe.

\section{National Forces and Educational Transfers}

One set of powerful actors in almost all nations is politicians and government officials or those who are interacting at the nation-state level. In the field of comparative policy, the term 'emulation' refers to a policy process in 
which politicians or state officials copy policy lessons taken from elsewhere (Bennett, 1991). In other words, politicians and top governmental officials are the ones who trigger a policy transfer. In the context of comparative education, 'policy borrowing' refers to a process by which education models, ideas, norms or standards are taken from one context and transplanted into another by politicians (Phillips, 2000, 2004; Phillips \& Ochs, 2003; Steiner-Khamsi, 2004). Policy emulation or borrowing is by no means a novel phenomenon. From the beginning of their existence, as noted by Siegel and Weinberg (1977), nations have sought to borrow and adapt successful policies, models and lessons from other nations, be it in the field of economy, politics, the cultural arena or in education. What is new and unprecedented, however, is the intensification and acceleration of policy borrowing nearly everywhere in the world and in nearly every field of activity, particularly in education and its sub-field of ELT.

Before examining the causes of receptiveness towards foreign lessons and ideas - labeled as 'externalization' by Schriewer (2004) - on the part of politicians, we should begin by posing a number of questions, as suggested by Steiner-Khamsi (2004): Why do politicians seek to borrow an education model from elsewhere? What are the stimuli triggering lesson drawing? What problems do politicians believe would be solved by borrowing a foreign model? David Phillips (2000, 2004; Phillips \& Ochs, 2003), one of the first scholars to pioneer research into the politics of educational borrowing, proposes various stimuli that may spark off cross-national policy attraction. Such stimuli could be economic motivations, political change or systematic collapse, internal dissatisfaction, negative external evaluation, or new configuration or allies, among others. Whatever the catalyst for change may be, it will create conditions that make possible the search for successful lessons, ideas or norms from elsewhere.

\section{Economic motives}

A major contributor to policy borrowing in the realm of education is the economic motive. Politicians and state officials often tend to perceive education as a main means to achieve economic growth and development. Such market-oriented perception towards education can be traced back to 1971, when Shultz proposed his neoliberal economic theory of human capital. The underlying assumption of his theory is the idea that the most efficient path to the national development of any society lies in the improvement of its labor force or its human capital. One way to improve human capital is to invest in education, as it increases productivity by teaching young people new skills, on the one hand, and contributes to 'development' and 'modernity' 
through the inculcation of so-called modern attitudes, on the other hand (Shultz, 1971). The human capital theory has provided a basic justification for underdeveloped and developing nations to look abroad to emulate a promising educational model that would lead them to economic growth.

The discourse accompanying English language, like that of education, equates language learning with economic and social progress and prosperity. English is represented as the language of global commerce, trade and culture. It is claimed to be inherently beneficial, holding out promises of social and economic development to all those who learn it (Barber, 1993; Crystal, 1997; David \& Govindasamy, 2005; McArthur, 1998). It is also considered key to improving social life for underdeveloped nations because it provides equal opportunity for all. Unraveling the 'myth of English as an international language', Pennycook (2004) provides an excerpt from the EL Gazette, which even goes one step further by suggesting that the widespread introduction of English into primary sectors around the world will eventually lead to the amelioration of worldwide poverty.

Today, the outlook most countries in the world are creating for themselves is shaped by global interaction, the global economy, the global job market, etc. What makes English pedagogy important to most politicians is the very vital role it plays in the virtually borderless world of today, giving the language a high economic value. As a result, many fast-developing nations such as Hong Kong, Singapore, Taiwan, the Philippines, Thailand and Malaysia, among many others, have placed a high premium on English language education (see David \& Govindasamy, 2005; Gill, 2005; Pennycook, 1998; Rubdy, 2005). It is not surprising then to see that in 2002, after a gap of 20 years, Malaysian politicians and language planners revitalized the policy of English as the language of instruction in selected fields - the very policy that Malaysian politicians had seriously fought against since the independence of their nation in 1957 (Gill, 2005). In order for this goal to materialize, the Malaysian leaders and language planners constantly linked English to economic growth and development. As a result, in 2002 English was chosen to be the only language of instruction in math and science at school level. This change of language policy was soon accompanied by a change in the school curricula, for which there was a need both to borrow a model from abroad and to rely on foreign experts and consultants, most particularly from English-speaking nations (David \& Govindasamy, 2005). Hence, an economic motive was one of the reasons that led Malaysian politicians to revise their school language policy and to look abroad for a promising English education model to emulate. The question as to whether the new ELT model would lead developing nations to achieve their desired goals is an open-ended question, but one that is worth exploring. 


\section{Radical socio-economic changes}

Another stimulus that could trigger a borrowing attraction on the part of politicians might be radical socio-economic changes in a country. Since the 1970s, for example, Saudi Arabia has profoundly invested in English language education. The main factor influencing the status and function of English was the Saudi's oil boom economy. The shortage of Saudi manpower in various professional domains has resulted in the necessity to import foreign manpower, whose language of communication is English. Examining the status of English in Saudi Arabia, Al-Haq and Samadi (1996) maintain that the Saudi politicians felt a need for English in order to cope with the country's radical socio-economic changes. The authors go further to argue that in Saudi Arabia the need to borrow ELT models and standards from abroad was not imposed by forces external to the country. Rather, it was shaped by the radical changes that took place within the socio-economic context of the nation since the early 1970s.

Saudi Arabia is not the only country in which politicians and policymakers displayed enormous interest towards English due to socio-economic transformation. In fact, other oil-producing nations in the Middle East, such as Qatar and the United Arab Emirates (Karmani, 2005), can fall into this category. With the inflow of petroleum dollars, these nations have undertaken massive modernization movements since the late 1970s. These reform movements, in turn, have led to an extreme reliance on foreign expertise and human resources, mostly from Western nations. It was within this milieu that English became a powerful tool in facilitating the economic and social modernization process.

\section{Political motives}

Another major cause for educational transfers is the political motive. Sometimes foreign-borrowed policies, models or reform movements reinforce the legitimization for a fundamental reform within the nation (Schriewer, 2004; Steiner-Khamsi, 2004). In the late 1970s, after being isolated for several decades from the outside world, the Chinese government felt a need for a major reform, which would lead the nation towards openness to the outside world and modernization. An independent, creative and productive labor force became the priority for Chinese officials, so education was the first sphere targeted for modernization (Ouyang, 2003). Comparative educationalists argue (Luschei, 2004; Phillips, 2004; Steiner-Khamsi \& Quist, 2000), that when it comes to policy borrowing, politicians first search for policy solutions in their own past, and if an organization's policy legacy is not strong enough 
to solve the current problems, they look abroad for answers. Since the Chinese homegrown education models were highly contested at home, Chinese politicians displayed an enormous interest in foreign education systems. As a result, they carried out a national campaign for reforming the curriculum towards a more Western-style liberal pedagogy. In such circumstances, English education received particular attention. To speed up the reform process, Chinese politicians borrowed the CLT model from Britain, the United States, Australia and Canada, and invited foreign consultants to demonstrate 'advanced' CLT to local practitioners (Ouyang, 2003).

However, politicians do not always make carefully measured and judged decisions when it comes to borrowing a model from abroad. They may borrow a model not meant to be fully implemented locally but rather to be used as a mechanism to meet their own immediate needs. This type of policy borrowing is known as 'quick fix' or 'phony' policies (Phillips, 2004). The implementation of CLT in China could be taken as an instance of a phony policy. Ouyang (2003) maintains that Chinese officials used CLT as a catchphrase to fulfill the political target of legitimizing the need for reform at home.

In other instances, especially after a regime change, policies borrowed from abroad are used to discredit the former regime and to justify a replacement of bureaucratic functionaries (Schriewer \& Martinez, 2004). We can trace instances of such policies in most post-Soviet countries. Examining the history of English in post-Soviet Russia, Ter-Minasova (2005) maintains that the newly elected Russian officials showed an enormous interest in English education and adopted a wholesale borrowing strategy, using English as a buzzword to discredit the Soviet regime and to legitimize the need for reform, which included openness towards the outside world. Subsequently, British publishers flooded Russia with ELT textbooks, many of which were poor in quality. After some time, however, the new generation of Russian politicians took a more moderate approach by asking local publishing agencies to design English textbooks relevant to Russian culture and life.

A radical political change within a country does not always boost policy borrowing or trigger receptiveness towards foreign influence. Steiner-Khamsi (2004) argues that, during the period of regime change, politicians may either drop their references to lessons from abroad or use them in a disparaging manner to distance themselves from foreign influence. Illuminating instances of hostility towards foreign influence could be seen in the case of English education in post-revolutionary Cuba (Corona \& Garcia, 1996) and post-revolutionary Iran (Borjian, 2009). In the introductory years of these revolutions, the politicians of both nations put enormous efforts into eliminating all ties with the United States. English was the first sphere targeted for indigenization and liberation from American influence. Nonetheless, such liberalization came to an end after 
two decades. Since the early 1980s and mid-1990s, respectively, Cuban and Iranian politicians have recognized the importance of English and thus have tolerated the publication of pirated foreign-produced English textbooks, most of them American and British, in their countries.

\section{Negative internal evaluations}

Politicians often compare their education systems to those of others. Gita Steiner-Khamsi (2003) outlines three types of reaction as the result of such a comparison: scandalization, i.e. when politicians highlight the weakness of their own educational system; glorification, i.e. when politicians only highlight the strength of their own educational system, and indifference, i.e. when no reaction is displayed. While scandalization intensifies policy borrowing, glorification stimulates policy lending.

Highlighting the weakness of one's own educational system in order to underpin educational reforms is evident in much of the literature of ELT. The Malaysian government, as previously discussed, used scandalization as their main strategy to revitalize the policy of English as the language of instruction in selected fields. Entirely disregarding the role of other variables, Malaysian officials and language planners constantly blamed their education system for producing students with low English proficiency, leading the nation to underdevelopment and Malay students to unemployment (David \& Govindasamy, 2005; Gill, 2005). A similar trend of scandalization appeared in Kenya and Uganda, two former colonies of Britain, in the early 1990s. In spite of tremendous investment put into the promotion of English, fear of 'falling standards' of English was a major issue in Kenyan and Ugandan government reports and media. According to Mazrui and Mazrui (1998), a major recurrent issue in the debate was how the problem of the quality of English was leading to poor performance in other subjects, giving the impression that virtually the whole education system of Kenya and Uganda was in crisis and that the only possible way to save the situation was to invest immensely more resources into raising students' English proficiency. To solve the problem, Kenyan and Ugandan officials turned to the British Overseas Development Agency and the British Council for support. Soon a chain of projects intended to strengthen the position of English were initiated and implemented in both nations.

The reaction of 'indifference' can best be seen on the part of post-revolutionary nations, including China (Ouyang, 2003), Cuba (Corona \& Garcia, 1996) and Iran (Borjian, 2009). In spite of the existence of various negative internal and external evaluations, the politicians of these nations seem to have decided not to borrow an education model from abroad, at least in the introductory years of the three revolutions, for political and ideological reasons alone. 
We have distilled various stimuli that may spark off an attraction towards borrowing a foreign education model, lesson or idea on the part of politicians and government officials. These stimuli are by no mean conclusive, and many others can be added to the list. However, as these instances illustrate, politicians are a major force in reinforcing educational transfers for which they may have different motives, including political and economic ones.

\section{Subnational Forces and Educational Transfers}

Educational transfers cannot be examined by primarily looking at the actions of top government officials or national forces. In fact, as the insights of policy analysts (Howlett \& Ramesh, 1995; Sabatier \& Jenkins-Smith, 1993) show us, it would be misleading to refer to those in positions of authority as the sole decision makers because many other people and social forces may influence policy outcomes. In the previous section we discussed the role of politicians and national forces in reinforcing educational transfers. In this section, we seek to identify the role of subnational forces, those societal actors who interact below the nation-state level - actors who do not hold governmental authority but who use their funds, power and/or voices to pull policy outcome, either directly or indirectly, in the directions they desire.

\section{Professional elite networks}

A major subnational force involved in educational transfers is the 'professional or elite networks', using Bennett's suggested (1991) term, corresponding to the 'professional tribalism' of Rose (1993). Professional networks refer to a group of connected individuals from a given profession such as TESOL and applied linguistics in the field of ELT. Having many professional concerns in common, through publishing, speech making and conferences, professional groups share ideas, expertise and information about a common problem with their transnational counterparts. 'Transfer in this sense', as Bennett (1991) notes, 'results from the existence of shared ideas among a relatively coherent and enduring network of elites engaging in regular interaction at the transnational level' (Bennett, 1991: 224).

As we will show in this book, in spite of Iranian politicians' 30 -year-long efforts to indigenize the field of ELT in the country, the 'indigenization' movement has failed to isolate local English professors and scholars from their transnational counterparts. Examining the content of the two Iranian ELT journals, we will illustrate how Iranian ELT professional networks not only discuss similar research problems with their transnational counterparts 
but also interact with them closely. The Iranian ELT journals seem to be one venue for the importation of ELT standards into the country. But can the Iranian professional ELT networks be perceived as helpless victims manipulated by their international counterparts? The answer seems to be negative as the borrowing process is happening quite willingly and voluntarily on their part. It is partly due to the fact of belonging to one transnational professional network, namely TESOL and applied linguistics, and consequently sharing similar ideas, expertise and information about issues surrounding ELT. In addition, they constantly refer to English as the 'global language of science, technology and research' in their academic discourse in order to question the product-oriented promotion of English supported by the country's politicians, and thus they are using foreign lessons as a means to legitimize the need for reform and to argue against policy decisions at home.

There are other motivations involved in supporting the idea of educational transfers on the part of professional elites. Sometimes professional networks may support educational transfers just as a mechanism to meet their own needs (Silova, 2004). Examining the motives of the local ELT stakeholders in collaborating with British experts on an exported ELT project in India, Holliday (2005) narrows his focus to a particular project, exported from Britain to Pune University in the mid-1990s. The project was intended to remodel the university's ELT curriculum and replace it with a new curriculum borrowed from the United Kingdom. While the local ELT stakeholders were aware of the so-called 'imperialistic' nature of the project, i.e. a model imported from the 'center' to be implemented in a 'periphery' nation, they have collaborated with their British counterparts to remodel their ELT curriculum to meet their own needs only. In this regard the local coordinator of the project states:

I am aware of this [linguistic imperialism]. In fact my colleagues in the department were also very concerned. But I think we've worked it out for ourselves.... I think we will be getting all that we have stated in our proposal. The hardware, i.e. computers, the photocopier, and other equipment for the resources center are some of the major inputs that will be provided. It's a good bargain! That's how I would like to look at it. (Jacob, 1996: 3; cited in Holliday, 2005: 130-131)

\section{Business enterprises and private educational institutes}

In many countries business enterprises act as yet another major subnational force in influencing the government to borrow a policy from abroad. Bernard Spolsky (2004) considers business firms as strong players in language 
policy formation and argues that they often 'establish their own language policies' (Spolsky, 2004: 52). There are many reports of business enterprises expecting their staff to use a certain language at work. Examining language policy reform in Malaysia, Gill (2005) and David and Govindasamy (2005) present strong evidence as to how private business and industrial sectors have implicitly reversed Malaysian language policy in the direction they desired. As English grew as the dominant language of business and industry in the country, the Malaysian Employers Federation executive directors created a discourse calling for a need to restore English as the language of instruction at tertiary level, as a means of alleviating unemployment due to the lack of English language proficiency in college graduates. Although Malaysian business enterprises certainly did not have the power to make any decisions about policy formation, the discourse they created contributed to the government's decision in reversing the country's school language policies and, consequently, in looking abroad for a promising ELT model to emulate for the implementation of the new language policy.

In Iran, as will be illustrated in the following chapters, private language institutes have been the pioneers of the importation of ELT practices into the country. Unlike their counterparts in the secondary and post-secondary education system, private English language institutes which target fee-paying students (across all age and proficiency levels) are permitted to offer their own chosen curricula and textbooks as long as they comply with the numerous rules and regulations set by the state. In order to attract fee-paying students, private language institutes constantly look abroad for promising ELT models and textbooks to emulate. The borrowing process is accelerated due to the absence of a copyright convention for foreign-produced materials. This leap forward for the private sector has enabled it to participate - albeit indirectly and within a limited scale - in the educational decision-making process, in which the government has had a virtual monopoly (Borjian, 2010).

\section{Students, parents, teachers and other stakeholders}

To the list of subnational forces that may reinforce educational transfers, one may add students and their parents, whose contributions are often underestimated in academic research. As noted by John Hanson (1997), former director of the British Council, students and parents may have no interest in 'the health, future, spread, or whatever of the English language'. What interests them is a view of 'their job prospects, their relationship with the rest of the world, their excitement in youth culture, a wish to be insiders, to be in touch' (Hanson, 1997: 22; quoted in Pennycook, 2001: 57). Although Hanson's statement has been viewed as a normative claim and has triggered many 
counter-arguments by critical applied linguists (Pennycook, 2001; Phillipson, 1992), his statement shed light on another dimension of educational transfers the role of subnational forces and their various motives for foreign lessons and ideas.

Due to the high economic value associated with English, many parents push for English or English-medium schools merely to establish a better future for their children. In Kenya, for example, Bunyi (2005) states that many rural parents and students expressed the view that 'their children went to school to learn English but not their indigenous languages, which they already knew' (Bunyi, 2005: 131). In South Africa, parents believe that 'English puts bread on the table' and students think that 'English opens their brains' (Probyn, 2005: 153, 164). Thus there is a strong correlation between English and economic prosperity at an individual level, so economic motives could serve as a major impetus for students and parents to push for English education.

There are other motivations involved for parents and students, including English being the language of wider communication and of the global academic world. Faced with growing competition from English-medium private universities, Istanbul Technical University, the major Turkish state university, had no other alternative but to install English as the medium of instruction in more courses in order to attract students (Reagan \& Schreffler, 2005). There is a study on Iran (Riazi, 2005a) that shows how well-off families in Tehran are increasingly sending their children to private English tutorial schools to prepare them for a possible college-level education abroad, which the state-run schools with their locally produced curricula do not provide.

Subnational forces, like politicians, have their own motives and interests in promoting educational transfers. However, it is not true that local actors always push for the borrowing of a foreign model. On some occasions, they may even resist actions taken from elsewhere. Investigating educational language policy in Pakistan, Tariq Rahman (2005) casts light on how Pakistani religious groups, following the Islamic ulema, resisted the governmentimposed policy of the use of English as the language of instruction in religious schools (madrasas). The ulema felt that this demand for English, even in pragmatic terms, was really part of the state's project 'to colonize Islam'. The resistance of this powerful interest group led Pakistani politicians to modify their policy. This time they suggested English only as the alternative medium of instruction (the other one was Arabic). Another instance of resistance on the part of subnational forces could be the case of Sri Lanka. Due to the liberalization of its economy in the late 1980s, the Sri Lankan government sensed a need for a kind of interactive and productive English to boost the country's economy. With the support of the American Asia Foundation and the British Council, new curricula, emphasizing the importance of English 
for interpersonal communication, were designed and foreign textbooks were imported. The transferred education model was, however, rejected by local higher institutions such as Jaffna University. This resistance was due to the rise of linguistic nationalism among the Tamil community, who preferred to speak in their own mother tongue rather than what they called 'the language of the colonizer' (Canagarajah, 1999).

In short, subnational forces have their own motives and interests for educational transfers, quite apart from those of their politicians. However, it is important to consider the multiplicity of agencies among subnational forces when examining the borrowing process of ELT practices. As eloquently stated by Steiner-Khamsi and Stolpe (2006), neither are all actors in favor of educational import, nor are they all ready to execute the orders given from above or by their politicians.

\section{Supranational Forces and Educational Transfers}

In addition to domestic institutions and actors, international and transnational institutions and networks shape educational policies in many countries. In the preceding sections, we discussed the role of domestic actors, including national and subnational forces, in facilitating educational policy borrowing. In this section we will turn our focus to the other end of the spectrum, international and transnational organizations and networks, including multilateral and bilateral donors and INGOs, to illustrate their roles in boosting policy lending. In doing so, we will first define two different types of policy transfer, namely 'harmonization' and 'penetration'.

Harmonization, as defined by Bennett (1991), refers to a policy process in which policy borrowing is not made exclusively by the state, but rather by the existence of a cooperative relationship, at least nominally, among governmental, intergovernmental and international/foreign institutions. It is an obvious fact that states, as autonomous entities, have the authority to close their borders to any foreign influences they disapprove of, but in reality the constraints rooted in the international systems limit their exploits to a great extent. In reality, therefore, a government may agree, under pressure from supranational forces, to borrow or emulate a foreign lesson, idea or model and implement it locally.

Penetration, on the other hand, refers to a policy process in which states are compelled by external forces to copy actions taken from abroad. In some instances of policy penetration, even 'members of one polity serve as participants in the political processes of another' (Bennett, 1991: 227). Penetrative policies were, in fact, more common in the colonial era, when the colonizing 
countries were the absolute rulers and/or decision makers and participants in the political process of the subject nations. Nowadays, penetration has long been replaced by the more subtle and implicit process of harmonization. Nonetheless, penetrative policies have not fully faded away. Due to their desire to join the European Union (EU), Turkey and Latvia, for example, have explicitly been forced by other EU members to change their language policies. The former was required to stop repressing minority languages, especially Kurdish (Skutnabb-Kangas, 2006), whereas the latter was expected to respect minority language rights, including Russian, in education (Silova, 2004).

\section{International finance organizations}

Educational transfer through supranational forces lies above all in the role of the international finance organizations (multilateral donors operating between governments). International finance organizations have received different levels of attention. For some scholars, these organizations were created by the hegemonic power (such as the United States in the post-World War II period) to overcome the legacies of colonialism (McMichael, 1996; Phillipson, 1992; Wallerstein, 1979), and to establish order in the international system for its own benefit (Frank, 1966; Peet, 1999). Others view the emergence of international organizations as a response to the common needs of states seeking a prosperity and security which can be achieved through cooperation with other states (Keohane \& Nye, 1989). No matter how one may perceive international institutions, one cannot downplay the vital role they have played in reinforcing educational transfers.

One of the most important international finance institutions to shape education policies in developing nations is the World Bank. According to Jones (2004), the World Bank is not only in the business of disbursing loans but also of lending ideas, norms and education models. It is evident that low-income countries are profoundly dependent on international grants and loans and, consequently, on international financial organizations. Due to economic necessity, these nations are often left with no other choice but to accept the obligatory 'loan-conditionalities' which often include educational reforms. But how does the World Bank drive the import and export of ELT pedagogical practices?

The World Bank does not formally and explicitly impose an educational language policy on the borrowing countries; it maintains that each country must itself determine the language policy it deems best fitted to its peculiarities (Brock-Utne, 2001). Critical scholars, such as Alamin Mazrui (1997), remark, 'The same institution that has been coercing African governments into overhauling their educational structures virtually overnight has suddenly 
become mindful of the national sovereignty of these countries and of their right to linguistic self-determinism' (Mazrui, 1997: 3). What Mazrui is referring to (inconsistency between what the World Bank says and what it does on the ground) is an excellent instance of what we have labeled so far as the subtle process of 'harmonization'. The World Bank is not explicitly involved in other nations' educational policies, but what it does instead is the imposition of a package of conditions on the loan-receiving countries, in return for its loans.

One condition consists of pushing the aid-receiving nations to go along with the neoliberal economic policy of 'structural adjustment', i.e. encouraging private sector initiatives, reducing the presence of government and allowing market forces to operate (Vavrus, 2002). Structural adjustment often leads to the reduction of government subsidies for education. In Africa, for example, these subsidies are an indispensable source for the promotion of instruction in local African languages (Brock-Utne, 2001; Mazrui \& Mazrui, 1998). Without such subsidies, schools will not be able to produce learning materials and textbooks in local languages and, therefore, they will turn to ready-to-use materials and textbooks often donated by British governmental organizations and non-governmental organizations (NGOs). Such donations, as is argued by critical applied linguists (Canagarajah, 1999; Gray, 2002; Holliday, 1994; Phillipson, 1992), enable the center agencies to penetrate into the heart of periphery classrooms, not only by limiting the traditional role of the teachers as intellectuals but also by driving them 'to an attitude of dependence on the prepackaged, ready-to-use material freely provided by Western cultural agencies' (Canagarajah, 1999: 84-85).

Another result of the World Bank's structural adjustment policy is school privatization, allowing the private sector to manage schools. In Tanzania, for example, many of these private schools advertise themselves as English-medium schools and follow foreign-driven curricula and textbooks to attract fee-paying students because a high instrumental value is attached to English (Vavrus, 2002). As will be discussed in the following chapters, in Iran private language institutes have been the most active agents of the importation of ELT models into the country. However, it is hard to imagine the accomplishments of the private sector without the initiation of policy privatization by the country's politicians. By extension, the policymakers would not have implemented this policy privatization if the World Bank had not mandated such a policy implementation in return for the loans. Therefore, it would be misleading to view the private sector as entirely 'active agents', who voluntarily borrow ELT practices from abroad, without acknowledging the contribution of the World Bank to the overall borrowing-lending process (Borjian, 2010). 


\section{Bilateral donors}

Unlike the international finance organizations, bilateral donors are governmental entities dedicated to distributing aid within a government, e.g. the American USAID or the British DFID. The donations can be divided into two categories: humanitarian and developmental. The latter is intended to help other countries achieve long-term sustainable development. Some American and British bilateral donors use their funds to support the promotion of English language education and related teacher training and curriculum development projects in other countries. This can be seen in Uganda and Kenya (Mazrui \& Mazrui, 1998), Tanzania (Vavrus, 2002), Mongolia (Steiner-Khamsi \& Stolpe, 2006), Sri Lanka (Canagarajah, 1999), Syria, Pakistan (Holliday, 1994, 2005), and in India (Widdowson, 1999), among other nations.

Many donor agencies are involved in educational transfer, with varying goals and motives. In Africa, for example, some bilateral donor agencies, including the German DSE and GTZ and the Swiss Development Agency, along with UNESCO, are trying to support the development of African languages. These donors often accuse the World Bank of pouring its funds into the promotion of English and French, former colonial languages, rather than African ones (Brock-Utne, 2001). Therefore, the multiplicity of agencies among bilateral donors should be acknowledged.

\section{International non-governmental organizations}

As the term implies, INGOs are non-governmental in nature, as opposed to bilateral (operating within a government) or multilateral (operating between governments). Although most INGOs emphasize their non-governmental nature, some, like the British Council, have a close link to their government. As Canagarajah (1999) argues, the special potency of these INGOs in influencing periphery ELT enterprises 'lies in their ability to side-step the other macro-level periphery organizations (such as state agencies and educational bureaucracy) and reach directly into the language classrooms by supplying textbooks and by conducting teacher training courses' (Canagarajah, 1999: 84).

The involvement of INGOs in the borrowing and lending process of ELT practices might be either explicit or implicit. An explicit participation might be the role of the British Council, which has been thoroughly documented by Phillipson (1992), whereas an implicit example might be the American Asia Foundation, which theoretically should not have anything to do with ELT. In Sri Lanka, for example, the American Asia Foundation played a vital role, albeit indirectly, in disseminating CLT to Sri Lankan universities. This 
type of implicit support, as Canagarajah (1999) maintains, included sponsoring the visits of short- and long-term American consultants, establishing pre-sessional course for new entrants, holding annual teacher orientation seminars and donating books and equipment. Another example of an implicit involvement might be the case of the British Council in post-revolutionary Iran. Examining the limited domain of operation of the British Council in the country, Borjian (2011) argues that a regulation issued by Iranian politicians has prohibited the British Council from participating in teaching English in the country since the 1979 Islamic Revolution. The existence of this regulation, however, did not prevent the British Council from taking part in the country's English education while the British Council was permitted to operate in Iran, albeit in a limited scale, from 2001 to 2009. Targeting Iranian students and teachers, the British Council had a good track record of selling its English products, from textbooks to dictionaries to audio-video materials, to Iranian students, organizing teacher training workshops and getting a British scholarship for Iranian English teachers.

\section{International ELT professional networks}

The TESOL and applied linguistics professional associations and networks are the other types of INGOs which have been active participants in spreading ELT practices globally, through conferences, curriculum projects, publications, etc. ELT-related professional networks have received different levels of attention. For some scholars, such networks are inherently apolitical and their emergence is due to the existence of common needs among English teachers and practitioners to share ideas, expertise and information about ELT-related problems with their transnational counterparts. For others (Canagarajah, 1999; Holliday, 1994, 2005; Mazrui, 2004; Pennycook, 1989, 2001; Phillipson, 1992), such networks are interpreted as being the product of the American and British TESOL/applied linguistics centers in order to maintain their own power in the field of ELT. Some scholars go so far as to label these networks as agents of linguistic imperialism. Phillipson (1992) argues that the trajectory of TESOL/applied linguistics networks, as the dissemination of the 'global' language, involves a one-way flow of expert knowledge from the 'center' to the 'periphery'. Aligned with Phillipson, Holliday (1994) uses the term 'unilateral professionalism', arguing that ELT-related 'professionalism is ethnocentric' (Holliday, 1994: 3). Calling unilateral professionalism a type of imperialism, Holliday further argues that this imperialism works, not at the government level, but in the more piecemeal relations between native-speaker teachers, curriculum developers, project managers and trainers and their colleagues from the rest of the world. Looking through 
a similar lens, Canagarajah (1999) maintains that the dominance of center applied linguistics networks stems from their ability to conduct sophisticated research using hi-tech facilities and then to popularize this knowledge globally through their publishing networks and academic institutions. Whether one perceives such networks as 'apolitical' entities or as 'regimes' and/or 'agents of linguistic imperialism', one cannot deny the vital role they have played in transferring ELT practices around the world.

Having examined some of the agents and motives of educational transfer through external forces, we can argue that educational transfers via supranational forces are different from those initiated by domestic forces, both national and subnational. In this case, educational transfers are reinforced by strong institutional forces exogenous to a country and its political system. Although states as autonomous entities have the authority to close their borders to any foreign influences they disapprove of, as Iranian or Cuban politicians have done over the past several decades, in reality the advancement of technological communication, together with many constraints rooted in the international systems, limits their exploits to a great extent.

\section{Conclusion}

Drawing on the fields of comparative education, education policy studies and critical applied linguistics, we have examined a body of isolated studies to extract the most common variables associated with the process, causes and agents of ELT-related educational transfers worldwide. We proposed a threefold framework, each part of which related to different conditions of ELT educational transfers involving various actors and different causes.

Politicians and top governmental officials often play a vital role in reinforcing educational transfer. Having examined a body of ELT literature, we explored a number of reasons as to why politicians make references to lessons from elsewhere. Economic motives are a major reason for politicians to look abroad in search of a promising ELT package to emulate. This is in turn due to the fact that English has often been equated with economic growth and prosperity. We explored instances of such a cause for policy borrowing in Hong Kong, Singapore, Taiwan, the Philippines, Thailand and Malaysia. Another major set of motives for policy borrowing is political. Especially after a regime change, foreign-borrowed policies tend to reinforce the legitimization of the new regime and its ambitions for fundamental reform and, moreover, these policies seem to help the newly elected politicians to discredit their predecessors (Schriewer, 2004; Schriewer \& Martinez, 2004), as in the case of post-Soviet Russia. There is also a direct correspondence between policy bor- 
rowing and the domestic policy conflict. When a current practice becomes contested, politicians turn to externalized references in order to legitimize the need for reform at home (Luschei, 2004). We saw instances of such a policy in China. Yet politicians may have to borrow a model from abroad because of negative internal evaluations, as in the cases of Malaysia, Kenya and Uganda. Whatever the cause of policy borrowing, it tends to create conditions for politicians to search for successful examples of education models and standards elsewhere.

Subnational forces have their own motives and interests in education transfer, as they are not homogenous entities. ELT-related professional networks may use lesson drawing for the obvious reason that most problems have common solutions internationally. Their perception is frequently shaped through writing, speech-making and conferences, often organized, not to mention funded, by transnational organizations. There are societal actors who use external references to argue against policy decisions at home, as in the case of Iranian English teachers and professors. There are local actors who use the process as a pretext to meet their own needs, as we demonstrated in the case of English curriculum reform at Pune University in India. Local actors may also resist national and international forces, as in the cases of English professors in Sri Lanka and the ulema in Pakistan.

In addition to domestic institutions, ELT educational transfers in many countries are reinforced by foreign institutions. These exogenous forces include international finance organizations, bilateral donors and INGOs such as the British Council and ELT-related professional networks. There are instances where the assistance of the international donor indirectly promotes ELT practices, as exemplified by World Bank's structural adjustment policy. There are external forces which directly support the promotion of English and actively lend ELT practices to developing nations, as shown in Uganda, Kenya and Tanzania. INGOs and ELT-related professional networks have also played a significant role in lending English education models to other parts of the world, through numerous projects aimed at curriculum improvement and teacher training, among others. Although one should seriously take into account the role of external forces in reinforcing educational transfers, one should equally bear in mind that supranational forces cannot guarantee the implementation of an exported model in a local context. Rather, there must first be a need for borrowing, and secondly some mutual understanding between the lending nations/institutions and the borrowing ones. Otherwise, the borrowed policies would simply be ridiculed as being 'phony' or will be used as a mechanism by local stakeholders to meet their own needs. 


\section{The History of English in Iran (1836-1979)}

All is flux, nothing stays still. Heraclitus; from Diogenes Laertiu

The history of English in Iran can be categorized into three distinct phases: during the reign of the Qajar dynasty (1836-1925), under the Pahlavis (19251979), and under the Islamic Republic (1979-present). In this chapter, the first two phases of English in Iran will be discussed at length as a background to the last phase, the subject of subsequent chapters.

\section{English Under the Qajar Dynasty (1836-1925)}

Early 19th-century Iran, known as Persia ${ }^{1}$ in the West at the time, during which English along with other European languages first entered, did not bear any resemblance to its glorious times under the Safavids in the 16th-18th centuries. ${ }^{2}$ Rather, it resembled an estate, as was eloquently stated by Gavin Hambly (1991: 44), 'long neglected by its successive owners'.

In the political sphere, the country was ruled by the medieval-oriented Qajar dynasty (1797-1925), whose kings' political incompetence, coupled with the country's primitive military forces, contributed greatly to Iran's humiliating defeats and great territorial losses to the imperial powers in the first part of the 19th century - losing the Caucuses and territories in Central Asia to Imperial Russia, and Herat (in today's Afghanistan) to Great Britain. In the spiritual sphere, the country was ruled by Shiite clergies, who exercised excessive control not only over the kings but also over the masses, the majority of them impoverished and illiterate. On the educational front, there was no modern school system whatsoever throughout the country, only the traditional maktabs, whose curriculum did not extend beyond the boundaries 
of religious instruction. Knowledge was restricted to Koran-centered knowledge, and was considered a monopoly of Ulama (Ashraf, 1997). In the linguistic sphere, Persian ${ }^{3}$ was losing ground outside its territorial borders. Persian, which had enjoyed a lingua franca status in a vast region, expanding from Turkey to Central Asia and India between the 14th and early 19th centuries, was gradually being replaced by English, due to the advent of British colonization in southwest Asia (Borjian \& Borjian, 2011). Within such a climate, Iran entered modern times and came into contact with the West - 'cultured Europe' - whose progress, prosperity and development was a source of fascination and admiration to Iranian intellectuals.

It is true that Iran entered modern times facing many challenges. Yet it did not face the fundamental challenge many other nations had to deal with: colonialism and its linguistic aftermath. Regardless of its great humiliating defeats and territorial losses to the imperial powers and their constant interventions in the country's internal affairs, Iran remained nominally an independent nation throughout modern times. As such, there was no dispute as to what the national literary and administrative language was (Persian), what the regional languages were (too many, in fact, to acknowledge here), and what functions each ought to play. Neither was there any challenge as to what role European languages could play in the country, as they have always remained foreign languages of instruction within the country's education system. That was not, of course, the case in the colonized nations, in which the imperial languages gradually replaced the local languages in all the administrative, literary and educational domains, as is described in detail in many books, including that of Tollefson and Tsui (2004) or Mazrui and Mazrui (1998).

It was in the 19th century that European missionary denominations, often in stiff competition with one another, became interested in practicing proselytization in Iran. Yet, unlike in the colonies, their power was limited in Iran, as these denominations had to seek permission for their operations in the country from the local authorities - notably the Qajar shahs who, in turn, were under constant pressure from Shiite clerics, the majority of whom were against all aspects of modernity. In addition, missionaries in Iran had to learn how to coexist peacefully with other rival religious denominations together with their secular counterparts, as they were all warmly welcomed into 19th-century Iran. On the strength of a verdict issued in 1841 by Mohammad Shah Qajar, Christian missionaries from all denominations were permitted to open schools in the country, as a means of bringing modern education to the nation, which has been perceived as the main cause of Western development and progress in Iran. Yet they were strongly prohibited from converting the Muslim population to Christianity. 
Under these conditions, missionaries of various denominations - most notably the French Lazarist Catholics, British Angelicas, American Presbyterians and, to a lesser extent, German Protestants - entered Iran, basing themselves in the remote northwestern towns of Urmia and Salmas in the province of Azerbaijan, where large Assyrian and Armenian rural communities had lived for a long time. Restricting their conversion activities to Christian minorities, foreign missionaries aimed to convert these Eastern Christian people to their own religion (Mansoori, 1986; Ringer, 2001). Starting in the 1840s, scores of foreign missionary schools were founded, first in the northwest of Iran and later throughout the country, thanks to their popularity among the Muslim population. Among these denominations, American and British missionary schools promoted the English language alongside their religious operations and medical activities. Although English was introduced into Iran in the 19th century, French enjoyed a primary (foreign language) position in the country's modern schools and among the country's intellectuals, partly due to its lingua franca status in the world and partly due to the neutral role of Imperial France in Iran's internal affairs. It took English more than a century to rise from being a little-known language into becoming the first foreign language in Iran, starting in the mid-1950s.

\section{American missionary schools}

Educational activities by the Americans ${ }^{4}$ reportedly began in Iran in 1834 with Rev Justin Perkins, a tutor at Amherst College. He was elected by the American Board of Commissioners for Foreign Missions as the first missionary to Iran. Like their French Lazarist counterparts, Perkins and his wife based themselves in the town of Urmia in the northwestern province of Azerbaijan, where a large body of Christian minorities of Assyrian and Armenian origins lived among the Muslims. These Eastern Christian peoples were the target of conversion to Evangelism and Catholicism by the American and French missionaries, respectively (Mansoori, 1986; Nateq, 1996; Ringer, 2001).

The first barrier to Perkins's mission was the language of communication. Nineteenth-century Iran resembled a culturally and linguistically diverse state. Each Persian province was distinguished by its own language, often mutually unintelligible one from another. Although Persian had long enjoyed a lingua franca status outside its territorial borders, its mastery in Iran was enjoyed by those who were either Persian by race (inhabitants of the central and western parts of the country), or by those who were literate. In the case of the province of Azerbaijan, in which Perkins's mission resided, the Christian minorities spoke either Assyrian or Armenian, whereas the vast majority of the Muslim population spoke Turkish. This linguistic and 
cultural diversity left its scar on Perkins's memoir, in which he wrote about his meeting with Patriarch Elias, the religious leader of the Nestorians in Urmia, to whom Perkins had to explain his mission using three interpreters, each speaking a different language:

I was obliged to converse with the Patriarch through three interpreters. Not knowing Turkish, the Bishop addressed him in Syriac [old Assyrian]. Our Armenian servant spoke to the Bishop in Turkish, and Mr. Haas [a German missionary] communicated with the servant in Armenian and with me in English. (Perkins, 1843: 31; quoted in Mansoori, 1986: 37)

Within such a milieu where barely anyone could speak English, Perkins began to learn the languages of the Christian minorities of the region, first from a German missionary residing in Tabriz named Mr Hass, and later from the two Nestorian priests that Perkins had hired as his assistants. The two priests, Mar Yohannan and Abraham, taught Assyrian and Armenian to Perkins, his wife and his missionary staff members, and they learned English in return. As is reported in Perkins's memoir, the two priests both showed an enthusiasm for learning English and by the end of the year they had acquired enough competence in the language to communicate with Perkins as well as to read and sing religious texts and songs during family devotion times; the two priests were perhaps Perkins's first students of English.

Having acquired enough local language and having gained the support of the Prince-Governor of Azerbaijan, Rev Perkins established the first mission school for boys in Urmia in 1836. Perkins's school was the first modern, European-style school founded in Iran. It was built in the basement of Perkins's house, with 17 students (Mansoori, 1986). The school curriculum followed the 'adapted model' of education which characterized American and British colonial education systems throughout the colonized lands. In an adapted education model, the language of instruction for the first few years was often a local language, which would be gradually replaced by English. This model differed sharply from the 'assimilation model' of schooling favored by French colonial education, in which the language of instruction was always French (Altbach $\&$ Kelly, 1984). Favoring an adapted model of education, Perkins used the languages of the Christian inhabitants, both ancient and modern, as the main languages of instruction. In this regard, he wrote in his memoir:

I succeed in furnishing reading, two hours per day, on manuscript cards in the Nestorian languages. Two hours, the scholars [students] read the scripture, in the ancient Syriac, which they do not understand, but 
learn to pronounce syllables, form words and spell in that way; and two hours they spend writing with their fingers in the sand boxes and in learning arithmetic from the abacus. (Perkins, 1843: 249; quoted in Mansoori, 1986: 109)

At Rev Perkins's request, the American Board of Commissioners for Foreign Missions sent a force to Iran to assist Perkins in his mission activities. The addition of these new forces strengthened the mission schools in Urmia. In 1838 the first girls' school was established in Urmia, which was expanded in 1843 into a boarding school for girls, called Fiske Seminary. The curriculum for the girls' school included reading, translating scripts from ancient languages into English, geography, arithmetic and natural history, in addition to singing, sewing and knitting. It is reported that by 1885 over 600 women could read and write in the Urmia district, compared to only one in 1835. This progress was, however, only among Nestorian women. Muslim girls were not allowed to attend school until 1906 when the first school for Muslim girls was opened by the American Mission in Urmia (Mansoori, 1986).

Between 1836 and 1870 American missionary activities were largely devoted to the welfare of Nestorian Christians. Yet in the early 1870s, the American Board of Commissioners for Foreign Missions decided to expand the mission beyond the Nestorians' region to all of Iran, in order to compete with their French Catholic Lazarist counterparts. As a result, American Protestants became a close ally of the British Anglican mission, dividing Iran into two spheres of interest: the northern part, which included the cities of Tabriz, Hamadan, Kermanshah, Qazvin, Rasht and Mashhad, became an American zone of interest, whereas the southern part, including the cities of Isfahan, Yazd, Kerman and Shiraz, became a British zone of interest. Tehran, the capital, occupied a central position between the two missionary allies (Borumand, 2002).

In 1878 American missionaries opened the first institution in Urmia to be known as a 'college'. It was a seminary and medical school. The language of instruction was English and the curriculum included industrial, academic, medical and theological studies. By 1895 around 110 students had graduated from the College of Urmia. The Memorial Training and Theological School for Boys was built in Tabriz in 1891. In addition to English, French, Turkish and Russian were added to the curriculum. Teachers were hired from the Armenian community and from abroad to teach local and foreign languages. For example, Mr Howard Baskerville and Mr Vauthier were invited from the United States to teach English and French, respectively. Educational work in other parts of the country continued vigorously under the leadership of the American missionaries and with the help of Persian teachers. New English 
schools were established in Hamadan, Kermanshah, Rasht, Mashhad and in Tehran (Boyce, 1954; Mansoori, 1986).

A turning point in the educational activities of the American mission in Iran came in 1989 with the arrival of Dr Samuel Jordan, who was to make important contributions to Iranian education. Jordan was assigned to establish a boys' English school in Tehran, but he had a dream of establishing an American college similar to those of Beirut and Cairo. In 1906, on his way to the United States, Jordan gave a speech about the track record of the 'Persian mission' in a conference held in Beirut, where he talked about the opportunity and even 'Christian duty' to open an English college in Tehran:

Tehran is growing rapidly. In contrast with the older cities, it has something of a cosmopolitan character and hence there is greater freedom in thought and action.... Changes in conditions make new demands. If we do not advance promptly, we shall forfeit our standing and lose the great opportunity that is now ours. One factor greatly in our favor is that English and American mission schools in other cities are starting boys in English who later come to Tehran to finish their education, and naturally enter our school. The world powers are recognizing the strategic importance of Tehran and are funding their schools to advance the interests of their countries. Shall we, the servants of Christ, be less wise in our generation than the children of this world? (Boyce, 1954: 14-15; quoted in Mansoori, 1986: 128-129)

Upon his arrival in the United States, Jordan started a campaign at Lafayette College in eastern Pennsylvania to secure funds and other assistance for the Tehran Boys' School. His effort was fruitful, as he was able to collect enough money to buy 44 acres of land in Tehran in order to establish the American College of Tehran. The college was inaugurated in 1925 with five classrooms, two lecture rooms, nine laboratories for biology, geology, chemistry and physics, a presidential house, two residential houses for faculty members, and two dormitories for students. The college had 10 American professors and a number of Persian teachers. In order to compete with other European missions, the Board of Trustees of the college applied for a charter from the Board of Regents of the University of the State of New York to give BA degrees to the graduates of the college. The Board of Regents issued a temporary charter in 1928, which was renewed every year until 1932 when an absolute charter was granted to the college. American missionaries are also credited with the establishment of the first institution of higher education for women in Iran in 1930, Sage College. Sage College appears to be the predecessor of the girls' school, Iran Bethel, established in 1874. Following a governmental decree 
in 1939 to close foreign schools and to purchase their properties, all American missionary schools were turned over to the Ministry of Education in 1940 and the government of Iran paid a total of US\$1,200,000 to the United States in return (Boyce, 1954; Mansoori, 1986).

\section{British missionary schools}

British schools in Iran were initiated primarily by the British Church Missionary Society (CMS), an Anglican church active across the Middle East in the 19th century. ${ }^{5}$ In order to compete with their French Catholic Lazarist counterparts, British Anglicans became close allies of the American Presbyterian mission, dividing Iran into two spheres of interest. Whereas Americans were active in the northern sphere of the country, the British were active in the southern sphere and operated in the cities of Isfahan, Yazd, Kerman and Shiraz. Tehran, the capital, occupied a central position between the two missionary allies (Borjian \& Borjian, 2007; Francis-Dehqani, 2008).

The work of the British CMS in Iran began in 1862 with Robert Bruce and his wife, in the Armenian township of New Julfa near Isfahan. The school they founded had absorbed 135 students by 1875, drawn from a variety of backgrounds: Catholic converts and Armenians and some 30 Muslim boys. The inclusion of the latter provoked the local clergy but to no avail. The Prince-Governor, Zell-al-Soltan, who was in favor of modern education, lent the school his official protection by ordering his courtiers to enroll their own sons there. As was the case with their American counterparts, the British hindered French Lazarist school activities within their own sphere of operation. In the city of Isfahan where Robert Bruce opened his English mission school, Eugene Boré, a devout Roman Catholic layman, had also opened a Catholic school. Yet it is reported that the British incited local preachers to close down the French school. This event is presented in one of Eugene Borés letters, complaining:

[A]lone in Iran, I am left to counter ... English jealousy, American rivalry ... and coldness on the part of some Persian authorities. (cited in Ringer, 2001: 114)

Boré was eventually forced to close his school in Isfahan and leave the town. Nevertheless, he persuaded the French Lazarist Catholics to come to Isfahan, where they reestablished themselves, starting in the early 1870s.

Within a decade the CMS schools grew sharply in number, embracing both sexes, involving altogether around 300 students. The Bruces succeeded in extending their geographical educational domain from the Armenian 
township into the Jewish quarter in the heart of the city of Isfahan. By the turn of the century, CMS had already begun to expand its educational activities into other towns such as Yazd, Kerman and Shiraz (Borjian \& Borjian, 2007; Francis-Dehqani, 2008; Ringer, 2001).

After a period of quiet during World War I, CMS resumed its activities in 1920, when Bishop William Jameson Thompson reopened the Stewart Memorial College with 27 students in Isfahan with a boarding option for non-resident students. It soon gained a good reputation and enrollment grew steadily up to 150 students. Its faculty rose to a maximum of 30 members, two-thirds of them British. The curriculum, based on the British secondary school system, placed a strong emphasis on physical education, and there were annual soccer games against their counterpart, the American College in Tehran. The British Oil Company and British Royal Bank offered scholarships to those students who would agree to join the company upon their graduation at the end of the eighth grade. In order to compete with their French and American counterparts, the college arranged a contract with London University to accept Persian students who had finished the 12th grade as MA prospects (Seyfpur-Fatemi, 1989). The CMS also sponsored the Stileman Memorial College for Girls in Isfahan, known later as Behesht-ayin High School. A notable graduate of the above-mentioned Stileman Memorial College was Soraya Esfandyari, just before she married Mohammad Reza Shah Pahlavi (Borjian \& Borjian, 2007). After becoming the queen of Iran, Soraya paid a visit to the school. ${ }^{6}$

Following the governmental decree in 1939 to close foreign schools and to purchase their properties, the Stewart Memorial College was handed over in July 1940 to the government and placed under the supervision of the Ministry of Education. It eventually became a somewhat mediocre public high school called Adab. The CMS itself survived by continuing with its charitable institutions, including a major hospital (Dehqani-Tafti, 1994; Seyfpur-Fatemi, 1989; Thompson, 1945).

\section{English in modern schools}

Apart from the American and British Missionary schools, native establishments contributed to some lesser extent to the promotion of foreign languages in 19th-and early 20 th-century Iran in both government and private capacities.

The first and only modern Iranian educational institution that was exclusively devoted to the promotion of foreign languages was the State Translation House (Dār al-Tarjome-ye Dowlati). Established in 1871 through the efforts of $\mathrm{Zi}$-al-Dowle, the institute planned to train students in foreign 
languages in order to meet the pressing needs of the government. The languages taught were French, English, Russian and Turkish. The school was tuition free, so students from diverse educational and family backgrounds could attend. It soon gained a good reputation and enrollment ran high. Sixty students are reported to have attended the school in just the first three months of its operation (Qasemi-Puya, 1998).

There were a few other schools which offered English. One was Dar-al-Fonun, the nation's first modern school. Established in 1851 in Tehran by Amir Kabir, the reformist Grand Vizier of Naser-al-Din Shah Qajar, Dar-al-Fonun was a polytechnic college attended by the sons of notables aiming for military and medical careers. Many teachers were French, who were always accompanied by an interpreter who translated the lessons into Persian (Qasemi-Puya, 1998). English was added to the school curriculum in the early 20th century. One of the few English teachers at Dar-al-Fonun was Isa Sadiq, who was to become a pillar of educational modernization in Iran under the Pahlavis (Sadiq, 1942).

Moshiriyeh was another school in which English courses were offered as part of the curriculum. It was founded in 1871 through the joint efforts of Mirza Hossein Khan Sepahsalar Qazvini, the Iranian Ambassador in Turkey, and Zi-al-Dolle, the founding director of the State Translation House. As well as English, French, mathematics and geography were part of the school's curriculum (Qasemi-Puya, 1998). At the turn of the 20th century other schools were founded in Iran, but the majority of them offered French, as it was the lingua franca of the world and the most popular language among Iranian intellectuals.

\section{English Under the Pahlavis (1925-1979)}

This phase began in 1925, when the medieval-oriented Qajar dynasty was replaced by the reformist Pahlavi dynasty, and lasted until 1979, when the Islamic Revolution put an end to some 25 centuries of monarchy in Iran. During Pahlavi era, a dramatic transformation occurred in the social, political and economic systems of Iran.

Under Reza Shah Pahlavi (1925-1941), progressive steps were taken towards building a modern and secular society. Certain effective measures were taken towards the modernization of industry, the transportation infrastructure, state administration and military forces (Abrahamian, 2008; Hambly, 1991). In the sphere of education the structure of modern schools was shaped. The government established a national, tuition-free and modern school system, providing an adequate education at elementary level in urban areas. The reign of Reza 
Shah also saw a ban on foreign schools. This took place in several steps. In 1932 a new bill was passed by parliament which prohibited foreign educational institutions in Iran from enrolling Iranian nationals in their elementary schools. Seven years later, the government informed foreign missionaries that all educational establishments should be turned over to the Iranian government. By 1940, the missionary schools had been turned over to the Ministry of Education and were subsidized by the government (Ashraf, 1997).

Under Mohammad Reza Shah Pahlavi (1941-1979), Iran began to build a growing relationship with the United States. Fearing Soviet expansionism, Americans regarded Iran as a serious ally, and extended their European Marshall Plan into the Middle East to include Iran. Along with the inflow of American aid, a large body of American advisors, technical experts, employees of aid agencies and technical and commercial organizations, together with private investors, came to Iran to assist the country in its economic planning. This in turn led Iran to look to the United States as a source to emulate in the social, economic, cultural and educational arena during the long course of the Cold War (Saikal, 1991).

\section{The British Council}

Founded in 1934 as a charity organization in England and funded by the British government, the British Council is the oldest British international organization for educational and cultural relations. Having offices in around 109 countries worldwide, the Council teaches English, recruits specialists for teaching and advisory posts, organizes a large body of cultural events, offers scholarships, and organizes a vast number of exchange visits to and from Britain. Nonetheless, the promotion of the English language has been the basis of the Council's operation worldwide. The operation of the British Council in Iran under the Pahlavis can be categorized into two distinct phases: the introductory phase (1942-1952) and the expansion phase (1955-1978). ${ }^{7}$

\section{Introductory phase (1942-1952)}

With the rise of Reza Shah to power in 1925, Iran began to build a growing relationship with the Third Reich, mainly due to the negative interventions of Great Britain and Russia in Iran's internal and external affairs throughout the 19th century. In the years between the two world wars, Germany played a major role in the economic development of Iran. As World War II loomed, Great Britain started to fear for the safety of Iran's southern oilfields, for which Britain held the majority of shares through the AngloPersian Oil Company. Reza Shah declared Iran's neutrality in the war and refused to expel the large German community living in Iran. When the war 
began, allied forces occupied Iran and forced the Shah to abdicate in September 1941. His son, Mohammad Reza Shah (1941-1979) was enthroned, and the country was divided into two geographical spheres of occupation, under the Soviet Union in the north and Great Britain in the south (Ferrier, 1987; Hambly, 1991; Saikal, 1991).

It was in such a milieu in 1942 that the first representative of the British Council came to Iran, as a counterweight to Germany's operations there - just as the BBC's Persian broadcasts had been launched in December 1940 to counter Germany's Persian language radio programs (Shahidi, 2001). The Council began to teach English in the southern zone of British influence. By 1944 attendance at the English language courses had reached over 4000 students. As foreign troops began to pull out after World War II, the Council started to expand its operation beyond the southern occupied zone to include all part of the country. By 1948, the Council had opened provincial branches, with libraries, in the major cities of Isfahan, Tabriz, Rasht, Mashhad and Shiraz, as well as in Tehran (EIr., 1989). These centers, therefore, offered Iranians the opportunity to learn English in probably much the same way as the missionary schools did prior to their closure in 1940.

The heyday of the British Council in Iran did not last very long, however. Its operation came to an end in 1952 in the midst of the Anglo-Iranian oil dispute. The situation was aggravated because Premier Musaddiq insisted on the nationalization of oil vis-à-vis the powerful consortium of international oil companies. The 1953 military coup against the premier finally brought the sociopolitical situation back to normal (Ferrier, 1987; Saikal, 1991). Fearing for the safety of its staff members, the Council closed down its representation in Tehran and the provinces in the second half of 1952.

\section{Expansion phase (1955-1979)}

The Council resumed its activities in Iran in 1955, while the country was building a growing relationship with the United States. It was within such a climate that the British Foreign Office appointed Derek Traversi as its principal agent and representative of the British Council in Iran (EIr., 1989). His plan was to expand the operation of the British Council throughout the country, perhaps as a counterweight to the Iran-America Society which eventually gained much popularity.

Under Traversi's directorship, the Council not only regained its previous strength but also managed to expand its operations. The Cultural Convention of 1959 was made between the Iranian government and the Council, permitting the Council to expand its activities nationwide. Between 1955 and 1978, the Council offered general English courses and international English proficiency exams, conducted teacher training summer workshops, provided 
consultation to Iran's Ministry of Education and promoted English for specific purpose (ESP) methodology and textbooks at university level (Yarmohammadi, 2005). Moreover, it brought around 10,000 students and visitors from Iran to Great Britain and offered 188 scholarships to Iranian students and scholars to study in British universities. It also sponsored a large body of cultural and educational activities (EIr., 1989).

In 1970, at the request of the Iranian government, the Council was engaged in a number of ELT education and training projects, including a major program for the teaching of English to employees of the Iran Oil Company (Sherkat-e Naft) in the cities of Ahvaz and Aabadan, and Khark Island (EIr., 1989). It also established a close partnership with the Association of Professors of English in Iran, ${ }^{8}$ through which two major semi-international conferences on ESP were organized at Isfahan and Mashhad Universities in early $1970 .{ }^{9}$ Tabriz University Material Development Project, which produced ESP textbooks for universities, was also supported by the British Council. It was through the efforts of the British Council that Iranian universities began to establish educational ties with their British counterparts: Tehran Teachers' Training College worked closely with Birmingham Young University, and Tabriz University with the British Council (Yarmohammadi, 2005).

By June 1978, under the directorship of John Hanson, the Council's representation in Iran was among the top three in the world. The Council had offices and centers in Tehran, Ahvaaz, Isfahan, Mashhad, Shiraz and Tabriz, with a total of 18 London-appointed staff, 98 local staff, 53 London-recruited English teachers and 38 Council-recruited staff working in Iran. In the gloomy days of terror, destruction and hatred which led to the Islamic Revolution, the Council withdrew its staff from the country in late 1978. Not long after the establishment of the Islamic government in Iran all the branches of the Council were shut down one after another (EIr., 1989). The Council reestablished its operation in post-revolutionary Iran in 2001, after a hiatus of 23 years, an account of which will be provided in what follows.

\section{The Cold War era and Iran-America relationships}

As World War II ended, the center of power gradually shifted from western Europe towards the United States and the Soviet Union, thus dividing the world into American and Soviet spheres of influence. British intervention in Iran's internal affairs since the early 19th century, the looming power of the Soviet Union and the Shah's constant fear of Communist threats from within and without formed the main impetus for Iran to turn to the United States as an alternative international power.

Immediately after World War II, the US government began to restore Iranian trust in American friendship. Dr Samuel Jordan, who had established 
the American College of Tehran back in 1925 and had earned great respect among Iranians, returned to Iran in 1945, this time on a mission from the US State Department to restore confidence in the mutual relationship between the two countries (Boyce, 1954). Jordan's mission lasted five months and his efforts were quite fruitful. Mohammad Reza Shah warmly welcomed and received him twice, and on his state visit to the United States in 1949 the Shah even gave an audience to Samuel Jordan and his family (Mansoori, 1986). On behalf of the US State Department, Ambassador Leland Morris wrote the following note of appreciation to Jordan, praising his sincere efforts in restoring the Iran-United States relationship:

The Department wishes me to express to you its sincere appreciation of your self-sacrificing efforts in Iran and its gratification that your mission has been carried out in a manner to reflect credit on you and to strengthen the position of your country in Iran. I personally wish to add my sincere thanks for your great efforts during the past five months which have been of the utmost importance to our relations with Iran. (Boyce, 1954: 49; quoted in Mansoori, 1986: 137-138)

Beginning in 1950, scores of economic, cultural and educational agreements were signed between the governments of Iran and the United States, causing American funds to be allocated to Iran in abundance..$^{10}$ Along with the inflow of American aid, there was a large group of US official advisors, technical experts, employees of aid agencies and industrial and commercial organizations, and private investors who came to Iran to assist the government. Iran was now looking at the United States as a source for emulation in the social, economic, cultural and educational arena. This trend was to continue during the upcoming decades of the Cold War.

\section{The English language and America's educational operation in Iran in the 1950s}

Beginning in the early 1950s, education became one of the major areas for American technical assistance. American development agencies began to mobilize their available resources to improve Iran's education system.

The Fulbright Commission was set up by the governments of Iran and the United States in 1949 in order to promote friendly interchange and understanding through academic, scientific and cultural activities between the two nations. Among the first cultural education establishments in the country to benefit from the Fulbright Commission was the dormant Iran-America Cultural Society (Anjoman-e Farhangi-ye Irān of Āmrikā). This had been 
established in 1925 under the leadership of Muhammad-Ali Foroughi, Reza Shah's distinguished Prime Minister. The Iran-America Society was considered by native statesmen at that time to be a counterweight to Soviet and British influence in Iran. The Society, however, was not to last long in its first phase of operation, given its very limited financial resources. Only in 1942, when the country was occupied by allied troops, was the Iran-America Cultural Society to be revitalized. The chief statesman supporting the idea was the Education Minister, Dr Isa Sadiq, a Teachers College, Columbia University graduate. ${ }^{11}$ Financially supported by the Fulbright Commission in 1949, the Iran-America Society began to expand its operations. ${ }^{12}$ Isa Sadiq became its president, and he proved to be a successful one. Reportedly, some 766 Iranians and 30 Americans were members of the Society by the early 1970s. Apart from offering English courses, the Society published the monthly Māhnāme-ye Irān o Āmrikā, screened documentaries on the American way of life, and organized weekly lectures..$^{13}$ Perhaps the most outstanding achievement of the Society was the student exchange program with American universities through the Fulbright Commission (Sadiq, 1974). ${ }^{14}$

Apart from Fulbright Commission, the other two players in Iran's education were the Point Four Program and the United States Agency for International Development (USAID). The Point Four Program was part of President Harry S. Truman's foreign policy to aid underdeveloped nations who had suffered in World War II. Iran had not been a battlefront, but it had helped the allies in winning the war. The main reason why Iran was included in the program was its vulnerability to the expanding Soviet Union, its northern neighbor. In 1951 the educational division of the Point Four Program in Tehran was founded by Hoyt J.B. Turner, and it was soon staffed by eight American advisors (Ashraf, 1997). Along with the Point Four Program and in cooperation with it, USAID also allocated its educational aid and human resources to Iran (Slocum, 1970). With the help of USAID and the expertise of American educationalists, various experimental educational projects were undertaken throughout the 1950s. These experimental projects laid the foundation for Iran's massive educational reforms in the 1960s (Ashraf, 1997; Hendershot, 1975).

The inflow of American aid and human resources created a demand for mastery of the English language in the 1950s. Alongside English courses offered through the Iran-America Society and the British Council, English gradually began to replace French in high school curricula, breaking French's virtual monopoly as the first foreign language of the nation, a monopoly that had been enjoyed since the late 19th century. This transition, however, was not without its problems. Appropriate English textbooks had to be produced. This was undertaken through close collaboration between the 
Iranian Ministry of Education and American experts. How much these textbooks were adapted to fit the local context is an open-ended question, however. Let us see what a student in the 1950s, Mohammad Ziahosseiny, who later became an American-educated professor of English, has to say about this issue:

The textbook provided by the Ministry of Education then was written by an American lady, D. Dorry. It was based on the Grammar Translation Method, though the period was the heyday of Audio-lingualism. The content was so strange and the subjects so far-fetched that even the teachers had difficulty understanding them. For instance, Iranians were not yet introduced to sandwich and hotdog; now one should just imagine how teachers could define these in the textbook. I remember a teacher did not know that the compound hotdog was an idiom. Imagine the consequence. (Ziahosseiny, 2005: 103)

Another problem was the lack of a qualified teaching force in the field of English. Very few schools enjoyed the presence of qualified English teachers. Anyone who claimed s/he could teach English was assigned to classes. In this regard, Mohammad Ziahosseiny notes:

The first session I attended my English class in my seventh grade, the teacher, a graduate of the School of Law, put English alphabet on the blackboard and asked the class to copy and learn them.... Students did not learn much English at school. Evening schools either did not exist, especially in the provinces, or had a very low attendance. Those who learned English tried on their own. I myself had a classmate who later majored in civil engineering. We bought simplified story books, read the stories one by one with the help of a bilingual dictionary, and recited the stories for each other. We developed our grammar and vocabulary, but I am sure no native could understand our pronunciation. (Ziahosseiny, 2005: 103)

\section{The English Language, America and the Iranian education reforms of the 1960s}

With the help of its oil-booming economy, along with the inflow of American aid and human resources, Iran witnessed massive educational reforms in the 1960s. The reforms of Iranian schools and universities were largely along the lines of American education, to replace the old French school system. Basic education was divided into three phases: primary school 
(five years), middle school (three years) and high school (four years). In higher education the academic year was broken down into two semesters. English became the first foreign language in the country's school system and was introduced in the middle school phase, replacing French (Al-e Dawud, 1997; Ashraf, 1997; Birashk, 1997).

Perhaps the zenith of the 1960s educational reforms was the creation of Pahlavi University in Shiraz in 1962, along the lines of American universities (originally the University of Shiraz, established in 1949). With the financial support of USAID, a team from the University of Pennsylvania helped with the layout of Pahlavi University, the first of its kind in the country. It was characterized by two years of mandatory general education in the humanities and science, a credit semester system and a letter-grading system (replacing the 1-20 point scale). English replaced Persian as the main language of instruction. Only Persian literature and history were taught in Persian (Ashraf, 1997; Slocum, 1970). The objective of the English program at Pahlavi University is well articulated by Strain (1971; cited in Yarmohammadi, 2005: 7), one of the American advisors working at Pahlavi University under an aidfinanced contract.

With regard to the Shiraz [Pahlavi University] English program, the goal of having a student body that is proficient in English as well as Persian remains a key objective of the university: in fact, it has become a goal of other Iranian universities as well. The textbooks used at Shiraz, and in some other Iranian universities, are generally the same as those regularly used in American universities; the main exception is Persian literature, history and culture. The assistance provided by the University of Pennsylvania in this field has consisted of a visiting applied linguist for 1965-1968 and the active recruitment of Direct Hire English teachers since 1967. (Strain, 1971: 34; quoted in Yarmohammadi, 2005: 7)

Lotfollah Yarmohammadi, an American-educated professor of English and the director of the English Department and English Language Center at Pahlavi University in the1970s, has made some interesting comments on the English program at Pahlavi University. He says that Pahlavi University 'was the only university in the country that succeeded in establishing a fullfledged EAP [English for Academic Purpose] program' (Yarmohammadi, 2005: 8). He further notes about Pahlavi University's English program:

The objectives of the program were well articulated. The students had to be proficient enough to attend major classes conducted in English. The English department had to be in close contact with the other departments 
to verify and evaluate the needs of students and the number of placement tests. Some students were exempted from taking English courses from the first day and some had to take two years of intensive English to pass the final proficiency exam; yet others never got to that point and had to leave the university before getting permission to take specialized courses in their own discipline. (Yarmohammadi, 2005: 8)

The universities outside Shiraz did not remain isolated from the world of the English language. Most of them established cultural and scientific relations with American universities. For instance, Ferdowsi University of Mashhad collaborated with Georgetown University, as did Isfahan Technical University and Tehran University with the University of Illinois (Yarmohammadi, 2005). Via this cooperation, Iranian students began to build relations with their American peers and thus found a way to improve their English.

The University of Mashhad [named after Ferdowsi], which I attended for my B.A. in English, cemented the foundation of my later studies. A number of major courses were offered by American and British professors, who were quite demanding. However, another major factor that helped me develop my lexicon and English proficiency was that I participated in a corresponding B.A. program in political science at the University of Minnesota. This required a lot of reading, and I had to sit for written examinations under the supervision of American professors. (Ziahosseiny, 2005: 100)

American educational planners also mobilized their available resources to develop appropriate textbooks for EAP at Iranian universities. Among various material development projects, the University of Tehran Project is conspicuous. The program was headed by the late Mehri Ahi and was directed by two American experts in applied linguistics, Ron Cowan and Katherine Aston. By 1978, the center had developed five EAP textbooks, of which two were for medical students, two for students of science and technology and one for students of business. In the introductory chapter of English for Students of Science and Technology (1978: xiv), the steps taken to prepare the book are explained. First, with the help of a sophisticated computer program, the research committee collected 100,000 words from the latest academic journals and books in the fields of science and technology. Then these academic journals and textbooks were reviewed in order to select relevant passages for the selected words. Syntactic analysis of the chosen passages was the next step. The frequency lists which were compiled from these studies provided a useful source for selecting items that would receive emphasis in the 
textbooks. Efforts were also made at Isfahan Technical University to produce EAP textbooks, but they did not go beyond the preparation of some mimeographed copies (Yarmohammadi, 2005).

The track record of the Americans' operations in Pahlavi Iran also includes the foundation of the first Association for Professors of English. Founded in 1973-1974 through the joint effort of the English Department of the University of California, Los Angeles (UCLA) and its Iranian counterpart, the English Department of Tehran Teachers' Training University (Dāneshgäh-e Tarbiyat-e Mo'allem), the association intended to professionalize the field of English in the nation and serve as a springboard for local scholars and professors of English to exchange ideas with their American counterparts. The association survived the Islamic Revolution but was closed in 1984 (Interview notes, TEFL professor, University \#5, 10 May 2008). ${ }^{15}$

Perhaps the most notable contribution to the promotion of English throughout Iran between 1950 and 1979 came from the Iran-America Society. This society withdrew its staff from Iran in late 1978. After the establishment of the Islamic Republic, the Iran-America Society was nationalized and became a state-run language institute with a new name, the Iran Language Institute (ILI).

\section{Shokuh English institutes}

Apart from American and British educational operations, English was also promoted in Iran by Iranian private institutions. Among these, the Shokuh English Language Institute was probably a pioneer in this field. It was first established in 1950, through the efforts of Dr Mohsen Shokuh, a physician. Known as Mike by his British teachers, Shokuh had begun learning English at the British Missionary School in Isfahan in the 1930s. In the 1940s he attended the British Council in Isfahan to continue his studies. With regard to his education, he says:

I was born in 1929 ... I was one of the students of British Missionary School in Isfahan. I attended the school when I was five years old. Well, I am a Seyyed Tābātabāi [i.e. a devout Muslim]! Yet, the irony is that I was not baptized to be Christian but I had a priest training/education. The language of instruction in the missionary school I attended was English only. And so, I didn't learn Persian well. After Missionary School, I attended British Council schools in Isfahan and have taken courses at highest level. ... This way I have come to develop a lasting love for English. (Personal interview with Mohsen Shokuh, Tehran, 30 April 2008) 
Afterwards, Shokuh attended medical school at the University of Tehran in 1948. However, his mastery of English was not taken for granted; he was asked by the authorities at the time to establish an English language school. The first establishment of this kind consisted of two rooms and 12 students.

When I came to Tehran in 1948 to study medicine, I didn't know much Persian. Well, I knew my mother tongue but I didn't know much bookish or classical Persian. I opened the first Shokuh School in 1950. I opened Shokuh, when people didn't know a-b-c-d [the alphabet]. Nobody knew English and nobody had ever spoken English. And so, I started it. I began to teach English, because I saw the pressing needs for English. Additionally, I was asked to teach English but let me not get into details. (Personal interview with Mohsen Shokuh, Tehran, 30 April 2008)

Within two years, Shokuh's operation had expanded and the institute had established three or four branches, each attended by some 700 students. By 1962 the Shokuh Language Institute had six branches in Tehran. It began to expand its operation into provincial towns. Just before the Islamic Revolution of 1979, Shokuh was one of the most popular and active centers for the English language in the nation, with around 60 branches.

Under the Islamic Republic, all the branches of Shokuh were shut down. Mohsen Shokuh was arrested and received a death sentence from the revolutionary judges, perhaps due to his close relationship with the pre-revolutionary authorities. He was eventually released as the situation calmed down. It took some years for the mainstream feeling to reverse its direction. Shokuh was eventually invited by the authorities of IRI to reopen his English language institute. Today, the Shokuh Language Institute has some 300 branches throughout the country.

\section{Conclusion}

This chapter has provided an account of English education in Iran throughout the 19th and 20th centuries, when the country was ruled by the mediaeval-oriented Qajar dynasty and the progressive state of Pahlavi, respectively. In each period, different variables have contributed to the introduction and promotion of English in the country.

Various European religious denominations based themselves in 19thcentury Iran, and brought with them modern-style European-based education. At that time English was mainly promoted by the American Presbyterians and British Anglicans, the close allies and rivals of the French 
Lazarist Catholics. Using an adapted curriculum, American and British missionary educational establishments introduced English, together with literacy in local languages, firstly to Iranian religious minorities, Armenians and Assyrians, and later to the country's Muslim population, albeit those from affluent families. To a lesser extent, English was also promoted by the local modern educational establishments - though their number was rather slim. Throughout the 19th century, American and British educational establishments attained a positive reputation among Iranians and high government officials and some of the children of the royal family attended these schools. Nonetheless, it was French that enjoyed a primary foreign language position in the country's modern schools and among Iran's intellectuals, which could in turn be attributed to the lingua franca status of the French language worldwide as well as the neutral role of Imperial France in Iran's internal and external affairs throughout modern times. Since its arrival in 1836, it took English more than a century and half to rise from a little-known language to the first foreign language within Iran's education system.

With the foundation of the Pahlavi dynasty in 1925, progressive steps were taken towards establishing a modern nation. Among many initiatives, the government was able to establish a national, tuition-free and modern education at primary school level in urban areas; thus European missionaries were asked to turn over their schools to the newly established Ministry of Education. By 1940, all the missionaries had left the country, while being compensated for their financial losses. Nonetheless, it did not take long for the British and Americans to re-establish themselves in Iran, this time via other venues, including the British Council, the Iran-America Society and many other aid-supported initiatives. After World War II, internal and external circumstances contributed greatly to the rise of English and its sustainability in Iran's education system. Iran's economic, military, industrial and educational ties with the West, the United States in particular, during the long course of the Cold War, helped with this process. The educational reforms of Iran in the 1950s and 1960s, the ample financial and technical support from the United States, and the presence of thousands of American and British experts laid the ground for English to arise. By the early 1950s, English had gradually replaced French as the first foreign language in the country's education; starting in the early 1970s, French lost ground entirely to English. The 1979 Islamic Revolution of Iran put an end to British and American educational operations in the country. It took the British a good two decades to reestablish themselves within the educational domain of Iran by reopening the British Council in 2001, only to be closed again in 2009 (Borjian, 2011). The Americans have not been permitted to return to the country ever since. 


\section{Notes}

(1) 'Iran' and 'Persia' are synonymous. The former has always been used by the Iranianspeaking peoples themselves, while the latter has served as the international name of the country in various languages, ever since it was introduced by the Greeks some 25 centuries ago. In 1935, however, the nationalist administration under Reza Shah Pahlavi made a successful effort to replace 'Persia' with 'Iran', apparently to underline the nation's 'Aryan' pedigree to the international community. The latter term used to signify all branches of the Indo-European language family (and even the 'race' of their speakers), but it was practically abandoned after World War II. In scholarly usage, 'Aryan' is occasionally used as a synonym of 'Indo-Iranian' in the linguistic sense (Borjian \& Borjian, 2011).

(2) The Safavid dynasty (1501-1722) was one of the most significant ruling dynasties of Iran, ruling the greatest Persian empire since the Muslim conquest of Persia in the 7th century. The Safavids' Persian empire was a vast region that included today's Iran, Republic of Azerbaijan, Republic of Armenia, most of Iraq, Georgia, Afghanistan and the Caucasus, as well as parts of Pakistan, Turkmenistan and Turkey. Safavids, together with their two neighboring empires, the Ottoman and Mughal, constituted the centers of the south and west Asian civilizations.

(3) Originating c. 6th century BC in Persis, a super-province on the southern Iranian Plateau, Persian has served as the administrative and literary language of Greater Iran throughout history. It was the administrative and literary language of the Persian empire under Achaemenians (550-330 BC) and Sassanians (AD 221-651). It survived the collapse of the Persian empire and the conquest of Iran by Muslim troops (AD 633-656). Two hundred years after the advent of Islam in Iran, Persian rose from the ashes of defeat, mainly through Persian literature which flourished during the 9th-11th centuries, and once again enjoyed a literary, cultural and administrative status, soon becoming known as the second language (after Arabic) in the Islamic World (Ashraf, 2006). Between the 15th and 19th centuries, Persian grew into a literary language par excellence and served as the lingua franca of a vast region - it was used not only as the administrative and literary language in Greater Iran but also in central Asia under the Turkic dynasties, the Anatolia under the Ottomans (together with Turkish), and in the Indian sub-continent especially under the Mughal dynasty. Along with the decline of the south and west Asian civilizations, represented by the Ottoman, Safavid and Mughal empires, and contemporaneous with the rise of the West as the world hegemonist, the status of Persian weakened in the Persianate world. Persian was officially replaced with English in British India (1834) and by Uzbek following the collapse of the Emirate of Bukhara by the Soviet army (1921). It survives as an official language only in Iran, Afghanistan and Tajikistan (Borjian \& Borjian, 2011).

(4) For a comprehensive account of the Americans' mission operation in Iran, educational, medical and humanitarian, see Ahmad Mansoori's doctoral dissertation entitled 'American missionaries in Iran, 1834-1934' (Mansoori, 1986), which was used as the primary source for writing the section on American Missionary Schools in Iran in this manuscript.

(5) For more on CMS's operations throughout the Middle East, see White (1996).

(6) Personal interview with Ms Badrolmoluk Karbasian, a graduate of Stileman Memorial College. 
(7) For more on the British Council's operation in pre-revolutionary Iran, see Encyclopeedia Iranica (EIr, 1989), a source that was used as a primary reference for the British Council activities in pre-revolutionary Iran, and for its operation in postrevolutionary Iran, see Borjian (2011). I am thankful to the International Society of Iranian Studies (ISIS) for permitting me to reprint the material used in my 2011 article. For the track record of the British Council around the world, see Phillipson (1992).

(8) Founded in 1973-1974 through the joint effort of the English Department of UCLA and its Iranian counterpart, the English Department of Tehran Teachers' Training University (Dāneshgāh-e Tarbiyat-e Mo'allem), the Association of Professors of English was the first professional association for English scholars and professors in Iran. The association survived the Islamic Revolution but was eventually closed in 1984 (Ziahosseiny, 2005). It was not until 2003 that Iranian professors of English were able to open another professional association for themselves, this time with a new name, the Teaching English Language and Literature Society of Iran, known by its acronym TELLSI, which was founded through the efforts of Ali-Akbar Mirhassani and the American-educated professor of English at Tehran Instructors' Training University (Dāneshgāh-e Tarbiat-e Modarres) (Interview notes, TEFL professors, University \#2, 15 December 2008).

(9) According to Yarmohammadi (2005), the Proceedings of the Isfahan Conference were published by Ziahosseini and Mountford in 1979. Yet nothing was available from the Mashhad ESP conference.

(10) From 1953 to 1957, for example, American aid to Iran amounted to a total of US\$366.8 million, followed by an average of US\$45 million each year for the next three years. In 1961, when aid was increased to an annual level of US\$107.2 million, Iran was one of the major recipients of American economic aid outside the NATO alliance (Saikal, 1991).

(11) Isa Sadiq received his $\mathrm{PhD}$ in International and Comparative Education from Teachers College, Columbia University in 1931. He was a devout supporter of American democratic and liberal education. Sadiq served as the vice president and as the president of the Iran-America Society in 1942-1944 and 1944-1953, respectively (for more, see Sadiq, 1974 and also Borjian, 2008).

(12) According to the US Department of State, the Iran-America Society was 'formally established in Tehran in the mid-1950s as a non-profit organization. It served as the venue for US cultural programs in Iran through the work of the United States Information Service (USIS) and was mandated to 'foster among Americans and Iranians a greater knowledge of the arts, literature, science, folkways, social customs, economic and political patterns of the United States and Iran, and to develop a deeper understanding of the similarities and diversities of the Iranian and American ways of life' http://www.america.gov/st/texttrans-english/2009/July/20090716172735xjs nommis0.8587109.html\#ixzz0x8xxuUL8 (accessed 21 August 2010). It is not clear to the present author whether the two societies merged in the 1950s to operate as one entity under one name, the Iran-America Society, as Isa Sadiq does not distinguish between the two societies.

(13) Under Isa Sadiq's leadership, the Iran-America Society invited many notable Americans as guest speakers, such as George Allen (American Ambassador to Iran in 1947), Will Durant (the renowned American historian) and George Cameron (the distinguished American archaeologist). 
(14) Among them were Farrokhruy Parsa (who later served as Iran's first female Minister of Education but was sadly executed by the Islamic authorities after the revolution), and Abbas Yamini-Sharif, who introduced children's literature to Persians; his poems have been a source of inspiration and enjoyment for Iranian school children over the last six decades (Sadiq, 1974).

(15) For more on this topic and the demise and rise of professional/elite ELT networks in post-revolutionary Iran, see Chapters 3 and 5. 


\section{Part 2}

\section{English in Post-Revolutionary Iran (1979-Present)}

If a victory is told in detail, one can no longer distinguish it from a defeat. Jean-Paul Sartre

It is doubtful that one could provide a comprehensive account of English education in post-revolutionary Iran, and be able to identify the politics, causes and agents of its two diverging trends of indigenization and internationalization, without scrutinizing the country's sociohistorical context. The politics and economics of educational transfers, as was eloquently noted by Schriewer and Martinez (2004), do not operate in a vacuum but rather they correspond directly with the 'sociological' aspects of the context in which they occur. Researchers who study educational transfer in isolation without searching within the deeper context to identify its social, political and economic causes would fail to make a meaningful contribution to educational transfer studies. Nor can one study the politics of English educational borrowing and lending in such a conservative, anti-colonial, anti-imperialist and isolated context as post-revolutionary Iran without taking into account the country's education system as a whole, and the dramatic transformation it has witnessed over time. An account of English education should be broad enough to include major issues and trends in the country's education system and their direct or indirect impact upon the country's English education, as English is part of education and the two go hand-in-hand. Moreover, educational transfers are made via a complex process (both borrowing and lending) and involve different sets of actors with different motives and interests (Steiner-Khamsi \& Stolpe, 2006). A comprehensive analysis of educational transfers should also include the role of different sets of actors, interacting below, above and at the nation-state level.

Hence, the account of English language provided in this part of the book is closely intertwined with the country's sociohistorical context on the one 
hand, and its educational system on the other. Moreover, the role of national, subnational and supranational forces has been assessed to better identify the agents of transfer and their motives in reinforcing or hindering educational transfers over the course of three decades.

This part is organized around four chapters (Chapters 3-6), each of which will focus on English education in a particular period of the history of post-revolutionary Iran:

Phase 1: The Revolutionary Period (1979-1988)

Phase 2: The Period of Reconstruction and Privatization (1989-1997)

Phase 3: The Period of Global Outlook (1997-2005)

Phase 4: Returning to Revolutionary Roots (2005-Present)

The Appendix summarizes the four major historical periods with regard to the four stages of educational transfers (as a whole) and ELT education transfers (in part) in post-revolutionary Iran. 


\section{The Revolutionary Period (1979-1988)}

Many teachers and professors who teach at our schools and universities are Westoxicated. Their task is to brainwash our youth with the incorrect education, rooted in colonial education.... Our universities should change fundamentally. They should be rebuilt from the ashes ... and new teachers with a correct training and education should be in charge of teaching our youth.. Ayatollah Khomeini, IRI Supreme Leader, 1980

\section{Introduction}

This period began with the victory of the Islamic Revolution in Iran in 1979, which put an end to the country's 2500-year-old monarchy (shähanshähi), replacing it with the governance of the religious jurisprudent (velayyat-e faqih), and lasted until the end of Iran-Iraq War in 1988. During this phase the newly established regime faced serious obstacles both from within and without. Chief among these were internal rebellions from opposition groups, leftists and liberal nationalists, in particular, and a prolonged war of eight years (1980-1988) with the neighboring country, Iraq. Internal rebellion and external aggression coupled with antagonistic attitudes towards the West brought the country enormous socio-economic disorders as well as pronounced isolation from the international community. As a result, during this period, the prime concern of the newly arrived politicians was to secure their power both internally and externally.

Driven by the uncontested power of religion and bent upon the ideology of creating an Islamic image of the country, the authorities of the Islamic Republic used religion as a means to denounce the legitimacy of the previous regime and to resist external influences. Energetic efforts were made to proclaim the grandiosity of the Islamic philosophy and the enormous opportunities it had to offer 
for the betterment of the lives of the country's people. It was claimed that Islam, like capitalism and socialism, had a philosophy and its own answers to contemporary economic, social and political problems (Bakhash, 1984; Fischer, 1983). Therefore, the goal was to create an indigenized model of development along the lines of the Islamic philosophy, not only to be used locally but also to be exported to other parts of the world, to Muslim nations in particular.

\section{Education and the Indigenization Movement}

Education was the first sphere targeted for indigenization and was used as a main means to impose the state's top-down ideological and religious beliefs upon the people of the country. The education system inherited by the Islamic Republic from its predecessor, the Pahlavi dynasty, was along the lines of American secular and liberal education. Yet, regardless of the pronounced aspiration for indigenization and antagonism towards the United States, the structure of the education system in post-revolutionary Iran remained virtually intact. The ideological aspects of education, however, underwent a dramatic transformation, moving from a secular system towards a religious one (Ashraf, 1997; Habibi, 1989).

For the newly arrived politicians, education meant no more than producing pious Muslims, gaining legitimacy for the Islamic regime, replacing Western and secular values with Islamic ones and, above all, expanding solidarity with other Muslim nations, Palestinians included. Taking advantage of its near monopoly over the country's higher education and education systems, the government undertook a massive educational reform, known as the Cultural Revolution, between 1980 and 1982. The Cultural Revolution was meant to indigenize the country's education system by eradicating all the so-called 'unwanted' Western-driven secular and liberal influences. It was also intended to train a new generation of a qualified skilled labor force to serve the goals of the newly established regime (Arjomand, 2009; Habibi, 1989; Mehran, 1997; Sobhe, 1982).

\section{The Cultural Revolution (1980-1982)}

After the 1979 Revolution, universities resumed functioning. Yet they were dominated by political activism and were strongholds for Marxists, liberal nationalists and other opposition groups. In response to this problem, the government closed all universities and colleges in April 1980, initiating what became known as the Cultural Revolution (enqeläb-e farhangi), which lasted for two years. Under Ayatollah Khomeini's orders, the Headquarters of the Cultural Revolution (setād-e enqeläb-e farhangi), later renamed the Supreme 
Council of the Cultural Revolution (showrä-ye 'ali-ye engelāb-e farhangi), was established within the Ministry of Higher Education in June 1980. This seven-member council was in charge of 'purification' and 'Islamization', the two pillars of the indigenization strategy of the country's education system (Ashraf, 1997; Habibi, 1989; Khomeini, 1980b; Sobhe, 1982). ${ }^{1}$

'Purification' meant exclusion, or perhaps trials, of anyone who was viewed as politically unfit. This included faculty and staff members as well as students who had close ties with the previous regime or who had acted against the interests of the Islamic regime (Sobhe, 1982; see also Regulation No. 8, in effect from 1 April 1985, issued by the Supreme Council of the Cultural Revolution). Purifying universities from these so-called 'unfit' elements was certainly the prime concern of the leader of the revolution, Ayatollah Khomeini, whose April 1980 speech reads:

Many teachers and professors who teach at our schools and universities are Westoxicated. Their task is to brainwash our youth with the incorrect education, rooted in the colonial education of the West.... The current opposition against the Islamic Republic [referring to student opposition movements in the early 1980s] is due mainly to the incorrect education these students received from their teachers and professors.... The truth is that these students do not know much about Islam and have not certainly received a correct education. Thus, our universities should change fundamentally. They should be rebuilt from the ashes... and new teachers with the correct training and education should be in charge of teaching our youth. (Khomeini, 1980a, author's translation)

Under the banner of the Cultural Revolution, approximately 8000 professors, about half of the total university faculty members, were purged. Thousands of the so called 'unfit' students were prevented from entering universities (Ashraf, 1997; Habibi, 1989). The pre-revolution Minister of Education, Farrokhru Pārsā - a champion of women's rights and the only Iranian woman who had ever held such a position - was arrested and executed by the Revolutionary Court on 8 May 1980 (Lentz, 1986). The wave of extremism and terror made half a million Iranian elites, primarily from the middle and professional classes, leave the country to live as émigrés abroad (Bakhash, 1984). On 31 October 1979, Ayatollah Khomeini commented on this reported trend of 'brain drain' in Iran as follows:

They say there is a brain drain. Let these decayed brains flee. Do not mourn them. Let them pursue their own definitions of being. Is every brain with - what you call - science in it honorable? Shall we sit and 
mourn the brains that escaped? Shall we worry about these brains fleeing to the US and the UK? Let these brains flee and be replaced by more appropriate brains.... [Iran] is not a place for them to live any more. (Khomeini, 1979)

After the departure of many Iranian elites, the country faced a severe shortage of a skilled labor force. Yet, in the face of the realities of the country, in 1982 Ali-Akbar Hashemi Rafsanjani, the spokesman of the Parliament at the time, urged expatriates to return home.

They can return to Iran. The people are prepared to forgive their past. We have great plans for building the country and we need you. (HashemiRafsanjani, 1982; quoted in Bakhash, 1984: 231)

In addition to 'purification', the Supreme Council of the Cultural Revolution was also responsible for the 'Islamization' of higher education. Islamization meant replacing the secular and Western aspects of higher education with Islamic and religious ones (Sobhe, 1982). In his April 1980 speech, Ayatollah Khomeini addressed university professors and students, defining what Islamization meant to him and to his newly established government:

The Islamization of universities means to be independent from the West, and the East [Capitalism and Communism, respectively]. An independent country requires an independent university [system] together with an independent culture. We do not dread military interventions of the world powers, nor do we fear their economic blockade. What we are most afraid of is cultural imperialism and having colonial universities, through which our youth would be trained to be at the service of either Capitalism or Communism. (Khomeini, 1980a, author's translation)

The implication of Islamization upon higher education is perhaps best understood by a major change in the university curriculum, moving from a secular system to a religious one. Based on a regulation (No. 21, in effect from 1 July 1985, issued by the Supreme Council of the Cultural Revolution), research methodologies, logic and economics were among the courses to be eliminated from university curricula. Biology, which had always been a required course for all majors at undergraduate level, became an elective course. Universities that could offer biology - albeit not along Darwin's Theory of Evolution but rather along the Islamic philosophy - were welcome to do so; otherwise, there was no need to offer such a course. While the education policies of the early 1980s kept pushing secular courses to the margin of university curricula, they brought 
religious courses to the center. New courses were added, including the Rules of Islamic Jurisprudence (4 credits), Islamic Ethics (4 credits) and Islamic Religious Texts ( 2 credits) (see Regulation No. 21, in effect from 1 July 1985, issued by the Supreme Council of the Cultural Revolution).

After the universities were gradually reopened in the fall of 1982, three divisions were established in each university to ensure the further Islamization of the country's higher education and to make Islamization a sustainable strategy. These divisions included: the University Crusade (jahād-e dānešgāh-i), Islamic Association (anjoma-e islāmi) and Disciplinary Committee (komite-ye enzebāti). The University Crusade was in charge of familiarizing university staff members and students with Islamic values through religious activities, such as conferences, lectures, books and even field trips to holy shrines, etc., as shown in Figure 3.1. The Islamic Association, with two branches (one for professors and the other for students) was responsible for spying on both faculty members and students and reporting directly to the Disciplinary Committee. The latter was in charge of expelling those students or faculty members who were viewed as 'unfit'. These three divisions are still quite active in every single university in the country (Habibi, 1989; Sobhe, 1982).

To facilitate the crafting of an Islamic higher education system 'independent from the West and the East', homegrown textbooks were needed to suit the ideologically driven curriculum, most particularly in the fields of the humanities and social science. To achieve this goal, two measures were taken. Firstly, in 1980, the former American-run press, Franklin Company Press, ${ }^{2}$ was nationalized and became a state-run publishing press with the new name of enteshārāt-e e'lmi farhangi, put in charge of producing homegrown textbooks suitable for local universities. In addition, in March 1985 under the orders of Ayatollah Khomeini, the Organization for Researching and Composing University Textbooks in the Humanities (sāzemān-e motàle'e va tadvin-e kotob-e 'olum-e ensāni-e dāneshgāhāa), known by its acronym SAMT, was founded (see Regulation No. 13, in effect from 27 February 1985, issued by the Supreme Council of the Cultural Revolution). Ayatollah Khomeini allocated a budget of 10 million Rials to SAMT, with the intention that the country would become self-sufficient, independent of Western textbooks permanently (Ahmadi, 2008; see also Regulation No. 16, in effect from 26 December 1985, issued by the Supreme Council of the Cultural Revolution).

Higher education was not the only domain undergoing a massive ideologically driven educational reform. The education system as a whole experienced such a transformation. The Ministry of Education in charge of pre-primary, primary, lower secondary, upper secondary and adult education was also quick to implement the 'purification' and 'Islamization' principles of the Cultural 


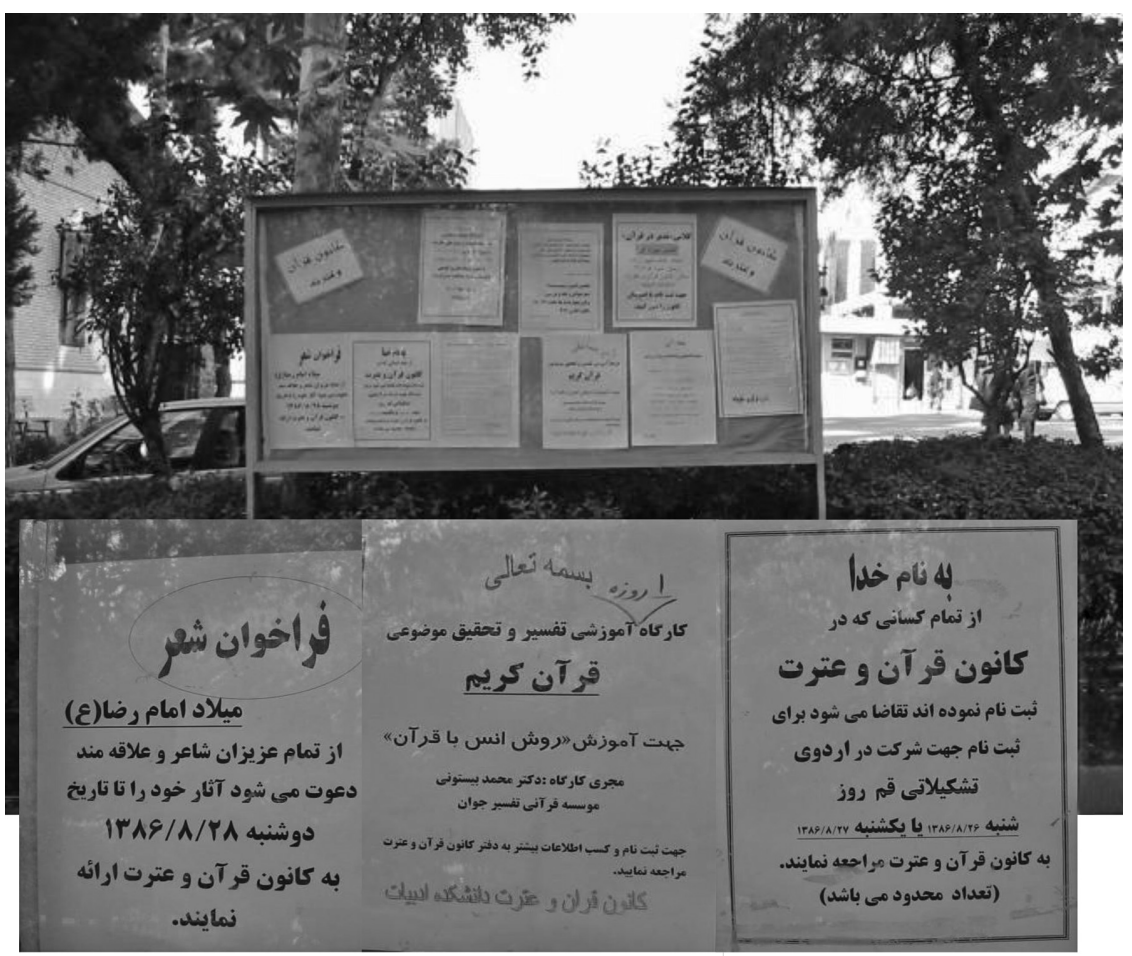

Figure 3.1 The bulletin board of the University Crusade (jahād-e dānešgāh-i), in charge of familiarizing university staff members and students with Islamic values through religious activities. The pictures on the bottom are enlarged fliers from this bulletin board. Pictured on the left is a call for poems in honor of Imam Reza, the eighth Imam of twelve imams of Shiites. The picture in the middle is the announcement of a one-day workshop on the Koran and interpretation of Koranic verses. Finally, the picture on the right is a field trip announcement informing students about a visit to the city of Qom, in which the shrine of Imam Reza's sister, Hazrat-e Masume, resides. (Field picture, University \#2, Tehran, November 2007)

Revolution within the schools system. All teachers and school staff members had to undergo a process of re-hiring, under which many of them were dismissed from their posts for having failed to meet Islamic standards. Regulations for behavior and dress codes conforming to Islamic ethics were established for teachers and students. The Ministry of Education moved quickly to bring Islamic ideology into the curriculum through a variety of means, including a thorough overhaul of the contents of school textbooks. In March 1980 the Textbooks Organization (sāzmān-e ketābhā-ye darsi), functioning within the 
Ministry of Education, was renamed the Organization for Educational Research and Planning (säzman-e pazhuhesh o barnāmerizi-ye amuzeshi). This organization consisted of 20 research groups; each was in charge of the task of revising the ideological content of textbooks for elementary and secondary schools, as well as for teacher training institutions. Energetic efforts were made to Islamize the content of textbooks to suit the ideologically oriented curriculum. The process of 'purification' of school textbooks was accomplished within the two years of the Cultural Revolution (Birashk, 1997; Majdzadeh-Tabatabai, 2006; Mehran, 1997; Shorish, 1988).

\title{
Resisting Linguistic Imperialism
}

\author{
In the past, there was no need for learning a foreign language. Today, \\ however, learning foreign languages should be included in school curricula.... \\ Today is not like yesterday, when our voice could not reach beyond the \\ national boundary. Today, we can stay in Iran but advertise [our religion \\ and export our revolution] to other parts of the world in different languages. \\ Ayatollah Khomeini; quoted in Birjandi \& Soheili, 2000: 1
}

At the dawn of the Islamic Revolution, the attitude towards foreign languages was profoundly negative. ${ }^{3}$ Foreign languages, meaning European languages, were treated as 'suspicious subject matters' and as the main means of the colonial powers to practice 'cultural and linguistic imperialism' upon Third World nations, Muslim countries included. Among foreign languages, English was considered most unfortunate as it was closely associated with the United States of America - or the 'Great Satan', as the Islamic authorities liked to call it. The intensity of hostility towards the West and European languages could perhaps be best explained by the closure of the Iran-America Society (Anjoman-e Irān o Amrikā) and the British Council (Anjoman-e Irān o Engelis), the most active centers of ELT in pre-revolutionary Iran together with those of their German and French counterparts. Although at some point the latter three institutes were permitted to return to Iran and continue their operations, ${ }^{4}$ this opportunity was never given to the Iran-America Society due to the lack of political relations between the two nations. The society was nationalized in the introductory years of the Revolution and became a government-affiliated entity with a new name, the Iran Language Institute (kānun-e zabān-e Irān).

Within such a climate no interest was displayed towards borrowing anything from the West, Western languages included. Instead, emphasis was placed on Esperanto, perhaps because it did not belong to any particular Western nation. Ayatollah Khomeini is known to have praised Esperanto and 
even encouraged Muslims around the world to learn the language as a means of communication among Muslims of different linguistic backgrounds. It is also said that Ayatollah Khomeini suggested that Esperanto should replace English as the international language. Shortly after the inception of the Islamic Republic, an Esperanto translation of the Koran was prepared and Esperanto began to be used in the renowned seminary of Qom, known in Persian as hozeye 'elmiye. Yet this favorable tendency towards Esperanto did not last long, as the Islamic authorities realized that Esperanto was supported by the followers of the Bahai faith. ${ }^{5}$ As a result, in 1981 Iranian politicians shifted away from their initial commitment to Esperanto (Harlow, 1998; see also Field notes, 9 November 2007 and 8 March 2008).

During the early years of the Revolution, the attitude towards individuals who were fluent in foreign languages was equally negative. They were often perceived as a group of Westoxicated, upper-class, secular individuals who were alienated from their own 'true' past or the great Islamic heritage, and thus had developed an admiration and love for foreign cultures and languages. Hence these individuals were often perceived as 'enemies', 'atheists' or 'agents of imperialism'. The intensity of hostility towards individuals who were in the business of promoting foreign languages could perhaps best be exemplified by the imprisonment of Dr Mohsen Shokuh, the founding director of the first and most active Iranian private English language institute, known as the Shokuh Institute, in pre-revolutionary Iran, as discussed in Chapter 2. Soon after the foundation of the Islamic Republic, Shokuh was reported to have been arrested and charged with the promotion of colonial activities and the dissemination of foreign language and culture. He was imprisoned and sentenced to death. Yet he was fortunate enough to escape this death sentence. Several years later, at the request of the very same government, Shokuh was invited back to reopen his English language institute, perhaps because there was a shortage of a qualified labor force competent in foreign languages, English in particular (Field notes, 18 April 2008).

\section{A heated debate and the consensus}

The questions as to what to do with foreign languages and whether they should stay on school and university curricula or be entirely banned were at the center stage of a heated debate among the new ruling powers of the country. In order to reach a consensus, in January 1980 the Supreme Council of the Cultural Revolution appointed Tahereh Saffarzadeh, aka 'the poet of the revolution', to head up the newly established Committee of Sketching and Planning Foreign Languages (komite-ye tarh o barnāmerizi-ye zabānhā-ye 
khäreje) (hereafter the Foreign Language Committee). Saffarzadeh, who held a doctorate in Literature and Literary Criticism from the United States, selected a number of university professors of foreign languages as members of the committee - albeit from among those professors who had escaped the purge. The first task of the committee was to reach a consensus as to what to do with foreign languages, above all English. As reported by Saffarzadeh (1990), a survey was designed and distributed among the professors and experts in foreign languages throughout the country. The survey was intended to assess the opinion of educators as to the fate of foreign languages in the country's education system. According to Saffarzadeh, almost 100\% of the respondents supported the maintenance of foreign languages at university and school level. Nearly all respondents voted for English as the first foreign language. As for the second foreign language, 54\% voted for French, 46\% for German, $27 \%$ for Arabic and 5\% for Russian (Saffarzadeh, 1990).

Based on the results of the survey and the comments and feedback of the respondents, as claimed by Saffarzadeh (1990), the Foreign Language Committee prepared a proposal to be reviewed by the Headquarters of the Cultural Revolution. The proposal consisted of two sections. The first section supported the maintenance of foreign languages and literature departments, namely English, French, German and Russian, at university level, for two main reasons: (1) to gain scientific and technological independence from the West; and (2) to translate Islamic ideology into foreign languages and export this revolutionary Islam to various parts of the world. The second section supported the maintenance of teaching English as the first foreign language in secondary school and university curricula. The committee suggested French as the second foreign language. Yet in practice this has never materialized (Saffarzadeh, 1990).

With this proposal at hand, the Headquarters of the Cultural Revolution set to work and decided on a number of policies. Phonological, morphological and syntactical aspects of English were selected to be included in school curricula. The sociocultural aspects of the language were perceived as 'inappropriate', and thus were entirely ignored, as is illustrated in Figure 3.2. The use of English as the first language of instruction in Iranian educational institutes was banned - which was only the case in the former Pahlavi and current Shiraz Universities, as discussed in Chapter 2.

Just as much effort was given to the promotion of Arabic in school curricula (IRI Constitution, Article 16). ${ }^{6}$ This was, in turn, due to profound aspirations on the part of the Islamic government to create a new cultural identity for Iranians as an Islamic nation by replacing every national symbol promoted by the Pahlavis with anything that would champion the cause of Islamic universalism. Persian, the national language, which had even survived Islam 


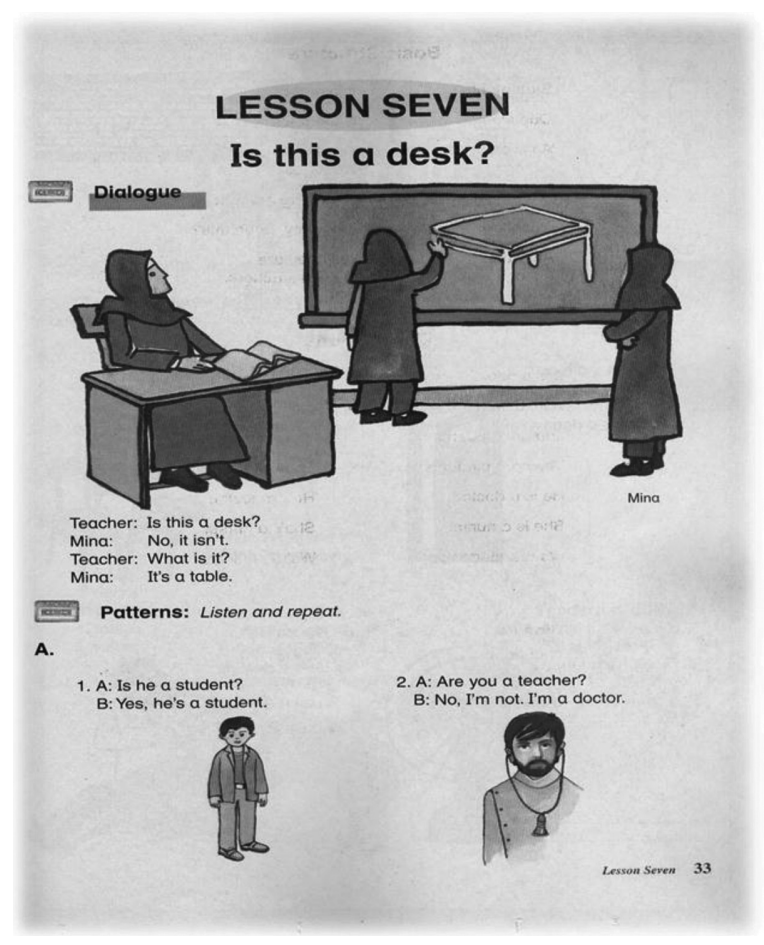

Figure 3.2 A page of an English lesson in a homegrown English textbook for the sixth grade, in which all the cultural aspects of the English language are removed. Not only do the characters have Iranian names, but they all follow strict top-down, governmentissued dress codes. (Field picture, Tehran, October 2007)

and the Arabic language after the collapse of Persian Empire in 7th century $\mathrm{AD}$, was now despised and the Shähnāma verses (Book of Kings) ${ }^{7}$ were removed from school textbooks under the pretext that their ancient mythology and Persian pre-Islamic history and heritage would propagate nationalism. Every possible effort was made to promote Arabic, which was declared as the 'first' language of Islam and the 'second' national language by the new constitution (Borjian \& Borjian, 2011). The long-term linguistic strategy of the Islamic Republic was once stipulated by Ali-Akbar Hashemi Rafsanjani, the spokesman of the parliament and future president, in 1981:

We accept that Arabic is the language of Islam, and ... the world's holiest language.... We believe that in the future Arabic, not Persian, will be the international language of Islam. We believe that, on the day the united 
Islamic government is established, certainly its language cannot be anything but Arabic. (Cited in Paul, 1999: 210)

The turning point of the language question was reached in 1988, when Ali Khamenei, the president and future supreme leader of the theocracy, spoke of the 'greatness' and 'holiness' of the national language and the 'revolutionary duty' to guard and promote Persian, a notion unheard of from Shiite religious leaders, who had generally expressed little interest in the royally supported, religiously neutral Persian (Borjian \& Borjian, 2011). As a result, Persian, as in the pre-revolutionary era, remained the sole language of instruction in all schools (IRI Constitution, Article 15). ${ }^{8}$ With the passage of time, the Supreme Council of the Cultural Revolution passed another regulation (No. 167, in effect from 16 October 1988), which placed more emphasis on Persian. Based on this new regulation, the time allocated to Persian in the secondary school curriculum increased. Additionally, Persian received more credits in the country's national university entrance exam. Regardless of the profound aspiration on the part of the Islamic authorities, Arabic instruction in schools remained intact. The Arabic of post-revolutionary Iran was, if not weaker, at least no stronger than it had been in its pre-revolutionary era.

\section{The problems and the solutions}

With the approval of the Supreme Council of the Cultural Revolution, the Foreign Language Committee began to carry out its ideologically driven reform agenda on teaching English as a foreign language (TEFL) in the early 1980s. Yet numerous problems were to be encountered.

One such problem was the lack of a qualified teaching force to teach foreign language courses. Foreign professors and experts had already left the country in their thousands due to growing hostility towards foreign nationals (Ashraf, 1997). The number of foreign instructors who had departed was so high that at Shiraz University (the former Pahlavi University) the number of instructors had to be doubled to fill the gap (Yarmohammadi, 2005). Iranian liberal and secular teachers and professors, many of them fluent in a foreign language, had been purged during the Cultural Revolution of 19801982. Yet those who had stayed were not entirely approved of by the government. In response to the problem of a shortage of English instructors, the Supreme Council of the Cultural Revolution promoted a strategy. A wave of 'pious' professors, who had neither a proper educational background nor prior experience in teaching a foreign language, entered universities to teach English along other foreign languages (see Regulation No. 8, in effect from 1 April 1985, issued by the Supreme Council of the Cultural Revolution). 
A typical 'unqualified' professor of English is described in the following excerpt from my interviews.

In his first year at [our] university, we knew him as the head of the Disciplinary Committee, who was in charge of expelling us [students] from university on ridiculous charges. We despised him very much and did our best to avoid him. The next year, he became our professor of English - General English. The textbooks assigned to this course were pirated American textbooks. But apparently the textbooks didn't have any answer key to be used by Mr 'Professor'. Over the course of one semester, the routine of our English class was as follows. One student would read out loud a given multiple choice question from the book with such a pronunciation most likely unknown to native English speakers' ears. Mr Professor would ask us to select the right answer from the given choices. We were all, of course, poor in English. So Mr Professor was the one who had to come up with the right answers. In the next session we had a good 10 to 20 minute review of the last week's work. Believe it or not, the whole review session would have been spent to re-correct $\mathrm{Mr}$ Professor's previous incorrect answers.... That was the story of English education while I was a student at the most prestigious university in the whole nation. The fact that we had to learn English from someone who had no idea of what English was is disappointing. Nonetheless, it was a source of joy and laughter for us. (Interview notes, Personal interview with a professor, 11 October 2007)

Another strategy to battle the 'linguistic imperialism' of the West was the foundation of a graduate school for the single purpose of training university professors, especially in the fields of the humanities and social sciences, as these were perceived to be most influenced by a Western worldview. Under the orders of Ayatollah Khomeini, a cleric named Ahmad Ahmadi was elected to collaborate with the Supreme Council of the Cultural Revolution to establish such a graduate school. The university was named the Instructors' Training University (dāneshgāh-e tarbiat-e modarres). Clergy from Oom and other religious cities were invited to this institution to teach philosophy and Islamic ethics courses. In spite of some initial resistance by student groups, the university was inaugurated in 1982, with Ahmad Ahmadi as Dean of the Faculty of Humanities, a position that he held for 14 years (Ahmadi, 2008). The ruling powers of the country were quick to place the idea of training 'pious' professors of foreign languages at center stage of the newly established university, where majors in English and French were offered. The university was determined to meet the needs of the country in training foreign language 
instructors with 'a correct Islamic education'. It is worth mentioning that applicants to this distinctive school were carefully screened. Only those with a proven record of pro-regime activities were admitted (Habibi, 1989; see also Regulation No. 8, in effect from 1 April 1985, issued by the Supreme Council of the Cultural Revolution).

Apart from a severe shortage of a qualified teaching force, the lack of appropriate foreign language textbooks was another major problem. To facilitate crafting an authentic and indigenized education system, homegrown textbooks were needed to fit the ideologically driven curriculum, most particularly in the fields of the humanities and social science (Regulation No. 13, in effect from 27 February 1985; see also Regulation No. 34, in effect from 19 July 1985; both regulations issued by the Supreme Council of the Cultural Revolution). As for the field of foreign languages, stress was placed on eliminating 'cultural imperialism' from school textbooks, and thus replacing Western values and culture with Islamic ones (Saffarzadeh, 1990).

In response to this quest, the Foreign Language Committee, as claimed by Saffarzadeh, the head of the Committee, placed its focus on the English language and invited professors of English from all over the country to join the committee to compile foreign language textbooks. Priority was given to the preparation of textbooks for General English and English for Specific Purposes (ESP). On the other hand, the textbooks required for the departments of foreign literature (French, English, Russian and German) were left to be pirated. During the two years of the Cultural Revolution (1980-1982), with the collaboration of local professors of English and the help of Iran University Press, the Foreign Language Committee was able to compile several ESP textbooks: English for Students of Science and books for students of engineering, medicine, agriculture, the humanities, sociology and economics. As time was short, photocopied forms of these textbooks were produced and distributed among students immediately after the reopening of the universities in 1982 (Saffarzadeh, 1990). The preparation of these textbooks is perhaps best explained by Professor Yarmohammadi, who was at the time in charge of the homegrown English textbook committee at Shiraz University:

The committee [for Sketching and Planning Foreign Language Textbooks] asked Shiraz University to compile a textbook of General English as quickly as possible. Dr Tahririan, Dr Jafapour and Dr Sedighi put together a selection from SRA [a commercial package for the teaching of reading widely used in the US at this time and still available] in which vocabulary items were partially graded and modified and exercises were provided for the selections. Some lessons having to do with the study skills also were added, and finally I was asked to edit the volume. The whole 
project was done within two months. Efforts were made to modify some selected foreign-made materials and remove unwanted cultural points. This, of course, was not successful. Then different universities were asked to compile textbooks for each college with ESP flavor without providing them with any specific framework. Shiraz University wrote the text for medical students and Tabriz University did the agriculture text, each following their own tastes. (Yarmohammadi, 2005: 13-14; emphasis added)

With the establishment of SAMT in 1985, the Foreign Language Committee merged with SAMT and became one of its research groups, known as the Foreign Languages Research Group. SAMT published its first ESP textbook, English for Students of Science, in 1988, three years after its establishment (Figure 3.3; SAMT, 2008).

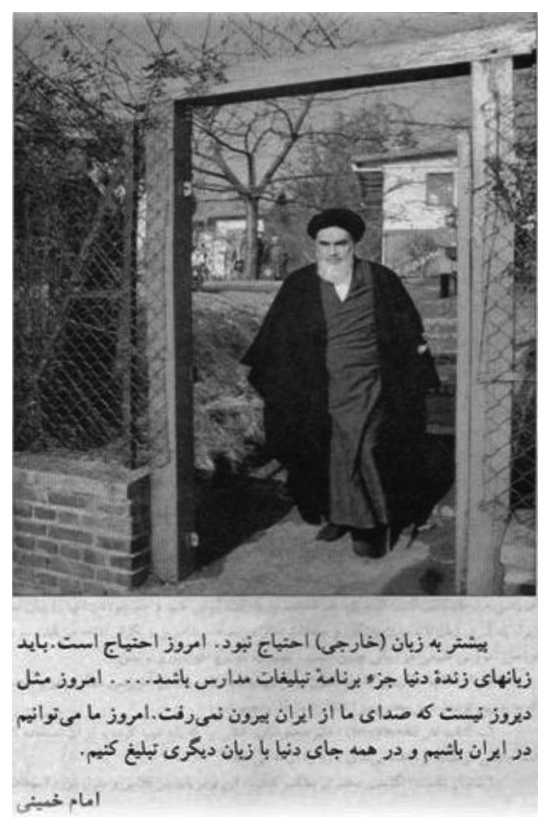

Figure 3.3 The first page of an Iranian homegrown English ESP textbook published by SAMT, with a comment by Ayatollah Khomeini, which reads: In the past, there was no need for learning a foreign language. Today, however, learning foreign languages should be included in school curricula. ... Today is not like yesterday, when our voice could not reach beyond the national boundary. Today, we can stay in Iran but advertise [our religion and export our revolution] to other parts of the world in different languages. (Birjandi \& Soheili, 2000: 1; author's translation) 
In 1982, when universities resumed functioning, English was offered as the first foreign language in university curricula. All university students, regardless of their majors and fields of studies, had to take a total of four required courses in English, which included: two courses of General English (for a total of four credits) and two courses of English for Specific/Academic Purpose (another four credits). Additionally, students who could not get a minimum score in English in the National University Entrance Exam, aka Konkur, had to take two more courses of pre-university English (a total of six credits), a prerequisite for General English (Interview notes, TEFL professor, University \#4, 1 February 2008).

English also remained in the secondary school curriculum. As in the prerevolutionary era, English instruction began in the first year of secondary school (sixth grade), with three hours of instruction per week. Likewise, as in the pre-revolutionary era, Arabic began to be offered in the first year of secondary school. The time allocated to Arabic was increased from 90 minutes to three hours of instruction per week (Interview notes, English teachers, School \#1, 28 December 2007).

\section{Marginalization of Subnational Forces}

There were two main features of the subnational forces of Iranian English education during this time: (1) the absence of professional or elite networks; and (2) the absence of private English language institutes.

Elite networking refers to a group of connected individuals from a given profession who have many professional concerns in common. Through writing, speech-making and especially conferences, professional groups share ideas, expertise and information about a common problem with their transnational counterparts (Bennett, 1991). The 'purification' principle of the Cultural Revolution of the early 1980s broke the back of a good part of the country's professional networks. Many educators were purged or voluntarily left their posts or left the country. The 'Islamization' principle of the Cultural Revolution brought a new wave of pious but unqualified professors into the field of English education. This arrival of new educators created a conflict between the older generation and the newly arrived one. As a result, the Association of Professors of English of Iran, established in 1973-1974 through the joint efforts of the English department of the Teachers' Training University (dāneshgāh-e tarbiyat-e mo'allem) and UCLA, the only association of its kind in the history of the country, became a battleground for the two wings of professors, and thus the association died out in 1984. A new association with a different name was established by 
the newly arrived professors of English but it did not last long (Ziahosseiny, 2005). It took Iranian professors of English a good two decades to get to their feet again and re-establish another association in 2003, the subject of our investigation in Chapter 5.

Private language institutes, too, were absent from English education during this phase. Immediately after the foundation of the Islamic Republic, all privately run educational institutes, private language institutes included, were closed and, over time, became converted into staterun educational centers. ${ }^{9}$ The best illustration of this is the closure of the Shokuh Language Institute, which had around 60 branches throughout the country. In the absence of privately run and foreign-run English language institutes, the state or the Islamic government became in charge of teaching English via secondary school or university curricula as well as through state-run language institutes such as the Iran Language Institute (kānun-e zabān-e Irān), the nationalized version of the pre-revolutionary Iran-America Society.

\section{The West, an Implicit Reference Society}

It would be normal to presume that, during the revolutionary phase of the Islamic Republic (1979-1988), supranational forces, most notably Western ones, were entirely absent from the country's education system in general, and English education in particular, judging by the negative attitudes adopted by the authorities towards foreigners. The most significant overtly hostile act was the expulsion of foreign experts from the country and the closure of foreign educational establishments, such as the British Council (Anjoman-e Irän o Engelis), the Iran-America Society (Anjoman-e Irān o Ämrikā) and their French and German counterparts, as underlined by the revolutionary slogan of 'strengthen national independence by relying on indigenized knowledge and the domestic labor force'.

\section{IRI study abroad programs}

In spite of this official rhetoric, a close scrutiny of the work of the General Office of Scholarship and Students Studying Abroad, part of the Ministry of Higher Education, ${ }^{10}$ provides evidence of the continuing influence of supranational forces in Iran under the Islamic Republic. The government first became aware of the need to educate its students in foreign countries in September 1982 in the wake of a severe shortage of skilled personnel, especially in the fields of medicine, engineering and higher education. This decision came as a 
surprise to a country whose leader, Ayatollah Khomeini, had sharply criticized his predecessors, the Pahlavis, for sending students abroad:

This kind of thought that one cannot get a proper education but to study overseas is invalid. This kind of propaganda is meant to encourage our students to go abroad and get acquainted with their [Western] ways of thinking, and carry them back to Iran. (Ayatollah Khomeini, quoted in Hazeri, 1993: i; author's translation)

Yet the Cultural Revolution of 1980 had 'purified' the country of trained and qualified specialists. The absence of skilled human capital, or 'internal dissatisfaction', using David Phillips's (2004) suggested term, paved the way for Iranian politicians to modify their original ideological commitments; they began to extend requests for technical and educational assistance to foreign universities. On 11 September 1981, the Ministry of Higher Education submitted a bill to the Islamic parliament, ${ }^{11}$ which was passed on 4 December 1982, permitting the two Ministries of Education and Higher Education to send a total of 500 students abroad on state scholarships annually (for more information on this bill, see Hazeri, 1993).

It might be assumed that the 'reference society' for the Islamist politicians of the time in Iran was either other Muslim nations or those with antiimperialistic revolutionary tendencies such as Cuba or China. The data, however, reveal otherwise. Between 1982 and 1985, 720 students were sent abroad on state scholarships from the Ministries of Education and Higher Education. Table 3.1 illustrates the proportion of the student population sent abroad in terms of absolute quantities and percentages.

Table 3.1 Number and proportion of the student population studying abroad on state scholarships, 1982-1985

\begin{tabular}{lcclll} 
Country & Number & $\%$ & Country & Number & $\%$ \\
\hline UK & 247 & 34.3 & Australia & 5 & 0.7 \\
\hline Romania & 209 & 29.0 & Germany & 2 & 0.3 \\
\hline USA & 110 & 15.3 & Sweden & 2 & 0.3 \\
\hline Belgium & 80 & 11.1 & France & 2 & 0.3 \\
\hline Canada & 34 & 4.7 & Yugoslavia & 2 & 0.3 \\
\hline Austria & 11 & 1.5 & Turkey & 1 & 0.1 \\
\hline Pakistan & 7 & 1.0 & Syria & 1 & 0.1 \\
\hline Japan & 6 & 0.8 & Greece & 1 & 0.1 \\
\hline
\end{tabular}

Total

720

Source: Hazeri (1993: 134, Table 5) 
Between 1982 and 1985, 720 students were sent abroad on state scholarships, most of them to Western countries. Of these the English-speaking nations of the United Kingdom and United States were ranked first and third, hosting $34.3 \%$ and $15.3 \%$ of the students, respectively, and together constituting the destination for half of the students on scholarships. Romania, with a share of $29.0 \%$, was an exception among the Soviet Bloc countries. It should be added that students who were sent to Romania had to return to Iran after staying there for a short period of time. The official justification was the low quality of the Romanian education system (Hazeri, 1993: 145). Certainly, the turmoil in political relations between the two nations must have been an overriding consideration in bringing these students back home. Only a small number (1.2\%) studied in the Muslim countries of Pakistan, Syria and Turkey.

If we add the proportion of the student population who studied abroad at their own personal expense to the above data, ${ }^{12}$ then the role of the United States and United Kingdom, along with other European countries, in training Iranian students of the post-revolution will become further apparent. Table 3.2 illustrates the proportion of the student population sent abroad at their own expense in the 1982-1983 academic year.

These statistics demonstrate the continuing influence of Western countries on education in Iran. In the face of the lack of specialists and experts in Iran, the country's policymakers were forced to revise their revolutionary principles and begin to borrow practices from the West. This borrowing, of course, was not done via bilateral official agreements or contracts, but rather via the student body sent abroad for educational purposes. Certainly these

Table 3.2 Number and proportion of overseas students on personal expenses, 1982-1983

\begin{tabular}{lcrlrll} 
Country & Number & $\%$ & Country & Number & $\%$ \\
\hline USA & 906 & 39.6 & Italy & 32 & 1.4 \\
\hline UK & 523 & 22.9 & Turkey & 29 & 1.3 \\
\hline Austria & 140 & 6.1 & Australia & 14 & 0.6 \\
\hline Belgium & 136 & 6.0 & Switzerland & 13 & 0.6 \\
\hline Canada & 92 & 4.0 & Japan & 12 & 0.5 \\
\hline Sweden & 92 & 4.0 & China & 10 & 0.4 \\
\hline Germany & 77 & 3.4 & Spain & 9 & 0.4 \\
\hline India & 58 & 2.5 & New Zealand & 7 & 0.3 \\
\hline France & 44 & 1.9 & Finland & 7 & 0.3 \\
\hline Pakistan & 40 & 1.8 & Other countries & 17 & 0.7 \\
\hline
\end{tabular}

Total 2285

Source: Hazeri (1993: 138, Table 8) 
students brought back educational practices, ideas, methodologies, textbooks and networking learned abroad. Regardless of their loyalties to the Islamic regime, they were in fact the first agents of change and the intermediaries between the Western and local education centers, the topic of our discussion in Chapter 5 about the rise of professional/elite networks.

Educational transfer from Western countries to the Islamic Republic was not equal across all academic disciplines. The distribution of the fields of study of 721 students sent abroad on state scholarships from the two Ministries of Education and Higher Education between 1982 and 1985 reveals the country's pressing need to overcome its medical (49.2\%), engineering (28.3\%) and scientific (13.7\%) shortcomings. ${ }^{13}$ As a result, educational borrowing and lending was more frequent in the above-mentioned three fields than in the field of the humanities, for which only $4.2 \%$ of students were sent abroad. The data are presented in Table 3.3.

The question as to the quantity of educational borrowing and lending in the field of English education in the early years of the Islamic Republic remains difficult to answer. The difficulty lies in the limitation of the data prepared by the General Office of Scholarship and Overseas Students of the IRI. The student record of those days does not specify the number of students who studied overseas in different branches of the humanities, foreign languages included. Yet, from my fieldwork data (interviews and survey questionnaire), it can be concluded that the top three countries which hosted Iranian English professors and graduate students in the post-revolutionary period were the United Kingdom, Canada and the United States, respectively. Out of 20 TEFL professors from the five selected universities that participated in the present study, eight studied abroad on state scholarships. Four had studied in the United Kingdom, three in the United States and one in Canada. Since these universities - all in Tehran - were not representative of the country as a whole, these data were supplemented by an e-survey. Out of 88

Table 3.3 Distribution of field of studies of 721 overseas students, 1982-1985

\begin{tabular}{lcc} 
Field of study & Number & $\%$ \\
\hline Medicine & 355 & 49.2 \\
\hline Engineering & 204 & 28.3 \\
\hline Science & 99 & 13.7 \\
\hline Agriculture & 33 & 4.6 \\
\hline Humanities & 30 & 4.2 \\
\hline Total & $\mathbf{7 2 1}$ & $\mathbf{1 0 0}$
\end{tabular}

Source: Hazeri (1993: 134, Table 5) 
Table 3.4 Proportion of English professors who studied in Iran and overseas

\begin{tabular}{lcc} 
Country & Number & $\%$ \\
\hline Iran & 60 & 68.2 \\
\hline UK & 12 & 13.6 \\
\hline Canada & 8 & 9.1 \\
\hline USA & 7 & 8.0 \\
\hline Australia & 1 & 1.1 \\
\hline Total & $\mathbf{8 8}$ & $\mathbf{1 0 0}$
\end{tabular}

Source: Electronic survey, winter 2008

respondents, $31.8 \%$ reported that they had received their $\mathrm{PhD}$ from overseas in the post-revolutionary era, of which $13.6 \%$ reported that they had received their $\mathrm{PhD}$ from the United Kingdom, 9.1\% from Canada, 8\% from the United States and 1.1\% from Australia. Table 3.4 illustrates where the English professors who participated in this study received their $\mathrm{PhD}$ qualifications.

Students who studied English abroad, although limited in number, have certainly played an important role in transferring ELT practices and innovative ideas, reference materials and networking from their host universities to local ones. In the absence of foreign experts and specialists, these students became agents of change and innovation. Certainly, they should be credited with raising the standard of English at home and for gradually taking the isolated post-revolutionary Iranian English education out of its international isolation. This topic will be discussed at length in the third phase of the history of the Islamic Republic, i.e. the period of global outlook 1997-2005, when the professional/elite networks had the opportunity to be reborn and stand on their own two feet in order to oppose the state's top-down rules and regulations; see Chapter 5.

\section{Conclusion}

This chapter has discussed the social, political and educational context of Iran during the first phase of the rule of the Islamic Republic (1979-1988). During this phase the political outlook of the country was highly ideological and filled with anti-Western sentiments. There are two main points to discuss in this section with regard to educational transfer: excessive indigenization and implicit externalization.

The first point concerns the enormous hostility displayed by Iranian politicians towards foreign influences. Instead, excessive emphasis was placed on 'indigenization', or looking to the country's past to draw new 
policy lessons. Steiner-Khamsi (2004) argues that during the period of regime change politicians may either stop referring to lessons from abroad or use them in a disparaging manner to distance themselves from foreign influence. The data from the first phase of the history of the Islamic Republic support such a tendency. The politicians of the Islamic Republic used indigenization as a reaction to the previous regime, which was claimed to have drawn excessively upon foreign lessons, Western lessons, in particular. This was intended to denounce the legitimacy of the previous regime in favor of the new one. It was also meant to proclaim the independence of the Islamic Republic from the Western nations.

Driven by the uncontested power of religion and bent upon the creation of an Islamic image of the country, the Islamic government used religion as the main means to materialize the indigenization thesis. Education was the first sphere targeted for indigenization, and thus witnessed a dramatic transformation. Islamic ideology was brought into the school curriculum through a thorough overhaul of the contents of school textbooks. Many pious but unqualified instructors were propelled into higher education, replacing foreign as well as secular native instructors. Moreover, a revolutionary university was established for the single purpose of training university professors and instructors with a so-called 'proper' educational background. A governmentaffiliated publishing house, SAMT, was also established in order to encourage native scholars to produce school and university textbooks to minimize the country's need for foreign-produced materials.

The impact of indigenization policies upon the country's English education was wide ranging. First, foreign experts and teachers were expelled from the country and foreign education centers were closed down. Second, private-run language institutes were also closed and, over time, became converted into state-run education centers. In the absence of private-run and foreign-run English language institutes, the state came to be in charge of teaching English throughout the nation. Third, English teaching was largely restricted to the phonological, morphological and syntactic aspects of the language. Sociocultural aspects of English were regarded as 'unwanted' and 'undesired', and thus were eliminated from school curricula. Fourth, the use of English as the language of instruction in any Iranian educational institute was banned. English was permitted to be taught only as a foreign language in school curricula.

Implicit externalization, another point to discuss here, refers to a process in which lessons are drawn from elsewhere while no explicit reference is made to the source country or institution (Schriewer, 2000; Vavrus, 2004). Contrary to what might be presumed, during this phase the Western education system continued to be emulated. The West remained the source of 
educational borrowing amid the nation's xenophobic tendencies. Such a contradictory attitude arose in the wake of the country's excessive need for trained specialists and a qualified labor force. Under the banner of the Cultural Revolution (1980-1982), much of the qualified labor force was purged. The absence of a skilled labor force, or 'internal dissatisfaction' in David Phillips's (2004) term, raised the government's awareness of a need to send Iranian students abroad to study on state scholarships. The top three countries which trained Iranian students in the early phase of the Revolution were the United States, United Kingdom and Canada. Hence, it would be misleading to assume that Iranian politicians were entirely hostile towards externalization. Borrowing and lending indeed took place, but not explicitly or via bilateral agreements or contracts. It happened implicitly and on a limited scale. It was not the result of coercion of supranational forces but rather the result of the country's excessive need to import expertise and knowledge.

\section{Notes}

(1) Consisting of a body of radical and conservative figures, the Supreme Council of the Cultural Revolution has been in charge of overseeing the country's macro and micro educational laws and regulations since 1980. It has also had the power to veto any so-called 'unfit' or 'undesirable' legislation with regard to any cultural and educational matters in the country (for more information about the Supreme Council, its history, responsibility, list of laws and regulations, see Khomeini, 1980b; Supreme Council of the Cultural Revolution, 2008; for a critical analysis of the Supreme Council and its operation, see Habibi, 1989; Sobhe, 1982).

(2) Franklin Publishing Company was founded in Iran in 1954. It was an American nonprofit organization, seeking to aid the development of indigenous book publishing in the developing countries of Asia, Africa and Latin America. The program in Iran (the first after Egypt) was the largest of the 17 around the world and was the most varied in the kinds of activities undertaken (Smith, 2000). Among its notable local managers/directors, Homayun Sanatizadeh (1925-2009), a graduate of the American College of Tehran, stands out. Under his directorship, Franklin Publishing Company was applauded in Iran for being the first and only press company that honored international copyright conventions in Iran, introducing pocket books to the country and bringing the best American and European books to Iranian readers via translation. The company also took part in fighting for various initiatives on eradicating illiteracy in Iran and publishing school textbooks for Iran and Afghanistan, among many other initiatives. After the Islamic Revolution, like all other American institutions, the Franklin Publishing Company was shut down and converted into a state-run publishing house but with a new name. For more on the track record of Franklin Publishing Press in Iran, see Smith (2000); on Homayun Sanatizadeh, see BBC Persian (2008); for Iran University Press, see Iran University Press (2011).

(3) Similar antagonistic attitudes towards foreign languages can be observed in other post-transformation societies in the 20th century, such as in Cuba (Corona \& Garcia, 1996), China (Ouyang, 2003) and Russia (Ter-Minasova, 2005). 
(4) For British educational operations in post-revolutionary Iran, see Borjian (2011); for Germany's educational operation in both pre- and post-revolutionary Iran, see Catanzaro (2001); for France, see Hadidi (1994).

(5) The Bahai faith was first founded by Bahaullāh in 19th-century Iran. This faith has been the subject of criticism by the conservative ulama in Iran ever since its inception. The hostility towards the followers of this faith was intensified after the foundation of the IRI.

(6) Article 16 of the Constitution of the Islamic Republic reads: 'Since the language of the Qur'an and Islamic texts and teachings is Arabic, and since Persian literature is thoroughly permeated by this language, it must be taught after elementary level, in all classes of secondary school and in all areas of study' (see IRI Constitution, 1996).

(7) The versified rendition of Ferdowsi, known as the Shâhnâma [Book of Kings], in some 50,000 couplets, is a Persian national epic (c. $1010 \mathrm{CE}$ ). It ranks with the Indian Mahabharata, the Greek Iliad and Odyssey and the Germanic Nibelungen Saga as one of the great epics of the world. The Shâhnâma not only revitalized Persian national history with its strongest affirmation and support, it also provided evidence that the Persian language had risen from the ashes of defeat with greater brilliance and richness as a potent symbol of Persian cultural identity (Borjian \& Borjian, 2011).

(8) Article 15 of the Constitution of the Islamic Republic reads: 'The official language and script of Iran, the lingua franca of its people, is Persian. Official documents, correspondence, and texts, as well as text-books, must be in this language and script' (see IRI Constitution, 1996).

(9) While the politicians of the Islamic Republic were too busy closing down the privately run education institutes, they supported the operation of a privately operated university, known as the Open Islamic University (dāneshgāh-e azād-e Islāmi). It had been founded in 1972 as the 'Open University' under the Ministry of Sciences and Higher Education (wezārat-e 'olūm o āmūzešse 'àlì), in order to expand facilities for higher education throughout the country (Menashri, 1997). After the 1979 Revolution, the qualifier 'Islamic' was added to the name of the university. Since 1981, the Open Islamic University has expanded its operations throughout the country, aiming to meet the needs of secondary school graduates for college education. Charging students fairly high tuition together with many other fees is considered to be the chief 'private' feature of this university. Apart from that, it is no different from other state-run universities, as it operates under the supervision of the Ministry of Higher Education and follows a curriculum similar to that of state-run universities (Ashraf, 1997).

(10) Since entry to this research site was not granted to me and the data from the early years of the Islamic Revolution were not available online, I used a secondary source to obtain the data. This source was a book entitled The Process of Sending Students Abroad, written in Persian by A. Hazeri (1993), a strong proponent of the Islamic regime. Due to his loyalty to the regime, he had access to the data of the General Office of Scholarship. His book was published by SAMT.

(11) Since Islamic politicians were increasingly fearful of the subversive impact of foreign education on these students, the Bill of 1982 proposed a number of political criteria for the admission of students to the program. These criteria were highly discriminatory in nature: they favored only pro-regime students; they mandated that the candidate have a clear proven record of struggle for the victory of the revolution, active participation in revolutionary organs, acceptance of the Islamic regime and respect for Islamic values. In addition, the candidate must be Iranian by nationality and 
Muslim by religion. The minimum of a high school diploma was the only scientific criteria added to the list (Habibi, 1989; Hazeri, 1993: 156). Nonetheless, this regulation was revised more than once. A revised version of the Bill was passed by parliament on 28 April 1985. In it, a minimum of a bachelor degree and married status were added to the list of criteria; on the other hand, the requirement of being a Muslim was dropped. The new Bill also allowed other ministries, including the Ministry of Foreign Affairs and the Ministry of Culture and Islamic Guidance, to send up to 50 persons annually to study abroad on state scholarships. On 19 July 1985, the Supreme Council of the Cultural Revolution also issued a regulation (No. 34, in effect from 19 July 1985), making the government accountable for allocating enough scholarship quota for clerics to be sent abroad for study.

(12) Students who were sent abroad at their personal expense had to go through the state's highly discriminatory selection process. In other words, the state was responsible both for the selection of the students and for the selection of the host countries.

(13) The data provided by Hazeri (1993) should be approached cautiously, due to many inconsistencies. For example, while the author claims 720 students were sent abroad by the two Ministers of Education and Higher Education between 1982 and 1985, the estimate changed to 721 when it was broken down into fields of studies (see Hazeri, 1993: 134, Table 5 for the inconsistency). 


\section{The Period of Reconstruction and Privatization (1989-1997)}

With the world constantly changing, we should adjust ourselves to the conditions of our lifetime and make decisions according to present circumstance. Ali-Akbar Hashemi Rafsanjani, IRI President, 1989

\section{Introduction}

The reconstruction and privatization phase of the IRI began with the election of Ali-Akbar Hashemi Rafsanjani, an advocate of the free-market economy, to the presidency in 1989, and lasted until the end of his two terms in office in 1997. During this phase, the Islamic regime came to recognize that it had to balance pragmatism with its initial revolutionary promises in order to maintain stability. The economic and political circumstances of the country were to be the basis of such a realization.

The prolonged Iran-Iraq War (1980-1988) cost Iran heavily in manpower and revenue. The number of casualties ran to hundreds of thousands. Thousands were captured or disappeared at the war front. Damage to human settlements and to industrial infrastructure was equally devastating: 51 cities and towns were damaged to varying degrees and more than 2.5 million people fled the war zone to areas farther away from the Iraqi border. Iraqi bombing destroyed much of the Iranian oil refinery capacity and reduced to debris industrial, commercial and residential areas in major cities in the southern and western parts of the country. When the Iran-Iraq War came to an end on 18 July 1988, the country's economy was in a state of turmoil, 
struggling with a high rate of inflation, unemployment and war damage (Amirahmadi, 1988a, 1988b; Bakhash, 1984).

In such circumstances, the political sphere of the ruling power was sharply divided into two opposing groups of pragmatists (kārgozārān) and radicals (ruhāniyun-e mobārez). The two groups had sharply distinct perceptions about the key issues of domestic and foreign policies. The pragmatists argued that, in order to rebuild the war-ravaged country, stimulate its ailing economy and train a qualified labor force to meet the needs of the country's economy, the Islamic regime must abandon some of its early revolutionary promises and accept technocratic solutions to domestic problems. Moreover, pragmatists advocated opening up to the international community and replacing Iran's antagonistic attitude towards the West with a moderate one. Radicals, on the other hand, could not tolerate any deviation from early revolutionary principles, and thus sharply opposed their pragmatist counterparts and rejected their technocratic solutions. Nonetheless, the death of Ayatollah Khomeini in June 1989 and the election of Ali-Akbar Hashemi Rafsanjani (hereafter Rafsanjani) to the presidency in August 1989 put an end to a decade of power enjoyed by the radicals (Amir Arjomand, 2009; Foran \& Goodwin, 1993; Milani, 1993).

With the rise of Rafsanjani to the presidency the mood and outlook of the government became more developmental and less ideological in nature. As a result, a change of orientation began to emerge in the country's domestic policy. The new president revitalized the pre-revolutionary Plan and Budget Organization ( $\mathrm{PBO}$ ), which had been suppressed since the foundation of the Islamic Republic in 1979. He put the organization in charge of preparing the country's long-term development plans (Ansari, 2005). During his presidency, the $\mathrm{PBO}$ worked closely, albeit behind the scenes, with international finance organizations, particularly the World Bank, as well as with the president and his administration to prepare two sets of Five-Year Economic, Social and Cultural Development Plans for the country. As an advocate of the free-market economy, Rafsanjani pushed for an economic decentralization policy. He blamed the economic shortcomings on excessive centralization, and thus advocated the privatization and decentralization of state-run industries and organizations. In his First Five-Year Economic, Social and Cultural Development Plan 1989-1994, the first of its kind in post-revolutionary Iran, President Rafsanjani set out policies for the participation of the private sector in the country's economy. He further outlined the rules and objectives of privatization policy in the Second Five-Year Economic, Social and Cultural Development Plan 1995-1999.1

A change of orientation in the country's foreign policy also began to appear during this phase. President Rafsanjani was determined to replace the 
antagonistic behavior of the Islamic regime towards the West with a moderate and more diplomatic attitude (Milani, 1993). An illuminating example of such a tendency was the resumption of a relationship with the World Bank in 1991 (Weiss \& Sanford, 2008). Having been ranked highly on the list of controversial and 'unwanted' Western organizations in the view of the Islamic authorities during the first phase of post-revolutionary Iran (1979-1988), the World Bank turned into a friend virtually overnight and became a close ally of Iran in its economic reconstruction endeavors.

\section{The World Bank, a Reference Society}

The World Bank's work in education cannot remain innocent of the Bank's primary role - financing. The Bank education loans are bound up with the Bank's ideas about education, especially how education can relate to development and to poverty reduction. Phillip Jones, 2004: 188

Notwithstanding pronounced disapproval from the United States, the World Bank resumed its loan lending to Iran in 1991, after a hiatus of 12 years (Weiss \& Sanford, 2008). Between 1991 and 1993, the World Bank played a major role in shaping the macroeconomic policy of Iran. ${ }^{2}$ In return for granting loans, Iran was held responsible for implementing the bank's 'structural adjustment policy', an offshoot of the neoliberal economic policy, which favors the privatization and decentralization of state-run agencies. It is intended to reduce the presence of government and the government subsidies system by transferring ownership from the public sector (state or government) to the private sector (businesses that operate for a private profit) in order to produce economic benefits (Stiglitz, 2003). With the cooperation of the World Bank, a structural adjustment policy was crafted as a quick-fix solution to the country's economic problems.

Borrowing both loans and policy lessons from the World Bank could have been a source of controversy for a country whose leaders had been known for their anti-imperialistic and anti-American sentiments. In order to reduce this controversy, no explicit reference was made to the origins of policy privatization in the country's policy documents of the time, most particularly in the country's First and Second Development Plans. Such implicit borrowing is called 'implicit externalization' by Schriewer (2003): that is, lesson drawing from elsewhere without making explicit reference to a country or an institution from which ideas or lessons were borrowed. The immediate outcome of policy privatization upon the country's education system was school privatization. 


\section{Implications of Policy Privatization Upon Education}

The consequences of the pronounced ideological commitment to Iran's education system over the first decade of the revolution began to emerge in the late 1980s. National education as a whole was in shambles: public schools suffered from crowded classrooms, split shifts, a shortage of qualified teachers, and inadequate, outdated and overtly religious textbooks and curricula (Ashraf, 1997). Universities suffered from a large drop in quality and performance. A large number of unqualified but pro-regime students and professors had been admitted into higher institutions (Habibi, 1989). An excessive emphasis on rote learning, memorization and unconditional obedience to the Koranic doctrines and Islamic ideology had left little room for creativity, independence or critical thinking (Ashraf, 1997; Mehran, 1997). As a result, as reported by Habibi (1989), by the late 1980s Iranian education was neither producing the skilled labor force required by the economy nor adequately trained graduates to meet the needs of the country's economy. ${ }^{3}$

\section{School privatization}

The failure of the country's education system to produce a skilled labor force and the country's pressing need to rebuild the war-ravaged economy set the stage for the new president and his administration to use internal dissatisfaction as a means to blame the existing education system. The shortcomings of the country's education were blamed on excessive centralization, inadequate budget allocation, the sharp separation of academic and technical-vocational programs, and a lack of cooperation between universities and industries (First Five-Year Plan, 1989). Internal dissatisfaction paved the way for the administration to justify the implementation of school privatization; its rules and objectives were first outlined in the country's First Five-Year Development Plan 1989-1994, and were later elaborated in the Second Five-Year Development Plan 1995-1999.

School privatization was indeed a controversial policy for a country whose leaders had claimed their unconditional support for deprived and dispossessed people (mostaz'afin). Yet rapid increases in the school-aged population throughout the $1980 \mathrm{~s}^{4}$ had created a high demand for education which could not be met by state-run schools. This, in turn, created pressure on the legislative body within the Islamic government - the parliament (majles) and the Council of Guardians (showra - ye negahbān $)^{5}$ - to adopt the decentralization policy proposed by the administration. They passed a law which 
Table 4.1 IRI educational indicators, 1980-1997 (\%)

\begin{tabular}{llll} 
Year & 1980 & 1988 & 1997 \\
\hline Adult literacy rate & 41.8 & 57.1 & 74.5 \\
\hline Combined enrollment ratio & 46.0 & 65.6 & 75.0
\end{tabular}

Source: Human Development Report of the IRI (UN, 1999: 14)

permitted the private sector to invest in education. Thus the privatization of education was taken on by a wider range of organizations. This has led to so-called 'non-profit' private schools (madāres-e gheyr-e entefä'i), which in fact charge fairly high tuition and other fees, becoming the norm, alongside public schools, since 1990 (Mehran, 1997). ${ }^{6}$

The educational indicators of Iran speak of significant progress between 1980 and 1997. They suggest that school privatization had a role in raising the nation's literacy rate from $41.8 \%$ in 1980 to $74.5 \%$ in 1997. It could also have influenced the boosting of enrollment ratios at all levels from $46.0 \%$ to 75\% within 1980-1997, as illustrated in Table 4.1.

These statistics, while impressive, do not mention quality and pay no attention to crucial factors such as the availability of qualified teachers, suitable educational facilities, adequate textbooks and curricula, to name just a few. It can be argued that the Iranian education system continued to suffer from a sharp qualitative decline throughout the 1990s mainly because school privatization never entailed decentralization of the curriculum. The curriculum - at all levels from K-12 to post-secondary education - continued to remain under the close supervision of the state; thus it was still highly centralized, nationalized and top-down (Borjian, 2010). For further information about the qualitative drawbacks of the country's education during this phase, see UN (1999).

\section{An economic outlook towards higher education}

Another outcome of policy privatization affected higher education. Drawing upon the country's First and Second Development Plans (19891999), it is clear that President Rafsanjani and his administration perceived higher education as a means to achieve economic growth. Under the banner of both developmental plans, considerable budgetary resources were allocated to higher education. Its share of public expenditure as a percentage of total public expenditure nearly doubled from $12.8 \%$ in 1988 to $22.5 \%$ in 1997, in the same time period as public expenditure on primary and secondary education increased slightly from $19.4 \%$ to $20.7 \%$ (Bureau for the Coordination of Projects and Programs, 1997; UN, 1999). In addition to the substantial budget allocation, both development plans reflected the priority now given to higher 
education. For the first time in the history of post-revolutionary Iran, we saw politicians talking about the creation of 'centers of excellence in scientific and specialized fields at selected universities', 'the improvement of the quality of research within universities' and the 'development of academic cooperation at regional and international levels' (UN, 1999: 62-63).

Improving the quality of higher education was thus the main concern of the existing administration. In 1993 the Supreme Council of the Cultural Revolution, under the direct supervision of the president, passed a regulation (No. 306, in effect from 28 May 1993), which proposed a new strategy for budget allocation to higher education. According to this regulation, the share of the annual budget allocated to a university and the level of autonomy in their internal affairs would be commensurate with the quality of education offered. This approach to higher education sharply differed from the initial revolutionary phase; it represented a clear shift from ideological commitment to expertise, knowledge and the quality of education.

\section{English in the Period of Reconstruction and Privatization}

In the second half of the 20th century, the idea that a knowledge of English was a precondition for economic prosperity and development had been gaining support worldwide (Crystal, 1997; Phillipson, 1992). Even Chinese and Cuban politicians, who had a comparable ideological background to those of the Islamic Republic, had begun to abandon their initial revolutionary commitments and had displayed enormous interest in English as early as the early 1980s (Corona \& Garcia, 1996; Ouyang, 2003). In such circumstances, Iranian indifference towards the role of English as a global language was striking.

In search of any explicit or implicit reference to English in policy documents of the time, the country's First and Second Development Plans (19891997) were examined closely. Although a significant amount of data was found on the improvement of the quality of higher education and perceptions of higher education as 'human capital', a tool for economic growth, there was no reference to English and its place in the country's higher education system.

The next place to explore was the regulations issued by the Supreme Council of the Cultural Revolution, in charge of overseeing the country's macro educational laws and regulations. Among the regulations issued between 1989 and 1997, two were directly related to English. Surprisingly, none of them was in favor of the language. Whereas the first regulation decreased the number of English teaching hours in the school curriculum, the second called for more 'indigenization' through the production of more homegrown textbooks. What 
is striking, however, is that at this very period the Islamic government displayed a welcoming attitude towards other European languages, including German. ${ }^{7}$ In addition, more efforts, at least at the discourse level, were made to improve Arabic within the school curriculum, judging by a signed agreement for mutual collaboration between the IRI and the Islamic, Educational, Scientific, and Cultural Organization (ISESCO). ${ }^{8}$

\section{English, the unfortunate language}

While education policies of the 1990s favored Arabic and displayed some tolerance towards German, they kept pushing English to the margins of school and university curricula. Starting in 1994, English teaching hours began to be reduced in school and university curricula, following the enactment of Regulation No. 306 (in effect from 6 April 1994, issued by the Supreme Council of the Cultural Revolution). While there was no explanation as to why English instruction was reduced, there was a detailed description as to how it should be reduced. The regulation states about the weekly hours of instruction that: (a) English for General Purposes (EGP) should be reduced from two courses (each of two credits) to one course (three credits); (b) Pre-university English ${ }^{9}$ should be reduced from two courses (each of three credits) to one course; and (c) Preuniversity English should be reduced from three hours to two hours and 30 minutes. Table 4.2 below illustrates the number of English courses offered at undergraduate level, before and after the enactment of this regulation.

As in the case of universities, English began to dwindle from the secondary school curriculum in the early 1990s. Teaching English was delayed one grade

Table 4.2 Number of English courses in Iranian universities, 1979-present

\begin{tabular}{llc} 
Years & Courses & Credits \\
\hline 1979-1993 & Pre-university English 1 (not required for all) & 3 \\
& Pre-university English 2 (not required for all) & 3 \\
& General English 1 & 2 \\
& General English 2 & 2 \\
& English for Specific Purposes 1 & 2 \\
& English for Specific Purposes 2 & 2 \\
& Total & 14 \\
\hline Pre-university English (not required for all) & 3 \\
& General English & 3 \\
& English for Specific Purposes 1 & 2 \\
& English for Specific Purposes 2 & 2 \\
& Total & 10
\end{tabular}


from the sixth to the seventh grade, i.e. the second year of secondary school. With the enactment of this regulation, secondary school students were required to study English for six years, up to grade 12, for three hours of instruction per week. No such reductions were made to Arabic: school students were required to study the language for seven years, beginning in the sixth grade.

\section{Mass production of indigenized textbooks}

The idea of producing local English textbooks, which originated in the introductory years of the Revolution, was actually implemented throughout the 1990s. The expansion of locally produced textbooks was partly due to the enactment of Supreme Council of the Cultural Revolution Regulation No. 294 of 16 November 1992, which allocated more resources to the Organization for Researching and Composing University Textbooks in the Humanities (SAMT). This regulation further granted SAMT permission to prepare textbooks for the fields of English language and literature, English translation and TEFL. As such, from 1989 to 1997, SAMT was responsible for systematically developing homegrown English textbooks. While in the 1980s it had published only one English textbook (English for Students of Science, 1988), this number grew in the 1990s to 61, of which 45 were for ESP and 16 for English literature, translation and TEFL. Tables 4.3 and 4.4 provide the list of English textbooks published by SAMT over this timespan.

Table 4.3 List of locally produced ESP textbooks published by SAMT, 1989-1997

\begin{tabular}{ll} 
Year & Title \\
\hline 1989 & English for Students of Agriculture I \\
& English for Students of Agriculture II \\
& English for Students of Medicine I \\
& English for Students of Social Sciences I \\
\hline 1991 & English for Students of Humanities I \\
\hline 1992 & English for Students of Engineering \\
& English for Students of Social Sciences II \\
\hline 1993 & English for Students of Medicine II \\
& English for Students of Dentistry \\
& English for Students of Nutrition \\
\hline 1994 & English for Students of Medical Records Administration I \\
& English for Students of Materials Science Engineering (Metallurgy) \\
& English for Students of Civil Engineering \\
& English for Students of Computers \\
& English for Students of Textile Engineering
\end{tabular}


Table 4.3 (Continued)

\begin{tabular}{ll} 
Year & Title \\
& English for Students of Economics \\
& English for Students of Food Sciences \\
\hline 1996 & English for Students of Industrial Engineering Book III \\
& English for Students of Industrial Engineering Book II: Industrial Production \\
& English for Students of Industrial Engineering Book I: Industrial Technology \\
& English for Students of Media Arts II (Television, photography, theater) \\
& English for Students of Media Arts I (Cinema) \\
& English for Students of Nuclear Science \& Engineering \\
& English for Students of Statistics \\
& English for Students of Archaeology \\
& English for Students of Accounting I \\
& English for Students of Chemical Engineering \\
& English for Students of International Law \\
& English for Students of Management \\
& English for Students of Mining (Exploration) \\
& English for Students of Veterinary Medicine \\
& English for Students of Physics \\
& English for Students of Mining (Exploitation) \\
& English for Students of Public Law \\
& English for Students of Food Science and Technology \\
& English for Students of Political Science II \\
& English for Students of Political Science I \\
& English for Students of Pharmacy \\
& English for Students of Criminal Law and Criminology \\
& English for Students of Animal Sciences \\
& English for Students of Journalism/Mass Media \\
English for Students of Medicine III \\
English for Students of Sociology \\
English for Students of Visual Arts (Painting, graphics, sculpture) \\
\\
45
\end{tabular}

Source: List of publications (SAMT, 2008)

Iranian ESP textbooks had two main purposes. Firstly, they were designed to encourage students to read English for academic purposes only. Browsing through these textbooks, it is clear that the main focus was on reading and grammatical skills. Regardless of their titles, these textbooks shared a pattern: lessons were organized around pre-reading activities, followed by a reading passage, a list of new vocabulary and a grammar lesson. The communicative 
Table 4.4 List of locally produced English textbooks other than ESP published by SAMT, 1989-1997

\begin{tabular}{|c|c|}
\hline Year & Title \\
\hline 1990 & A Study of Islamic Texts in English Translation I \\
\hline 1991 & Reading Through Reading: General English for University Students \\
\hline 1992 & Literary Prose: A Selection \\
\hline \multirow[t]{2}{*}{1993} & Oral Reproduction of Stories \\
\hline & Readings in Psychology: Selected Texts \\
\hline 1994 & Testing Language Skills From Theory to Practice \\
\hline \multirow[t]{3}{*}{1995} & The Practice of Literary Terminology \\
\hline & An Introduction to Literature in English \\
\hline & Basic English for University Students (pre-university) \\
\hline \multirow[t]{3}{*}{1996} & Reading Comprehension II \\
\hline & Poetry in English \\
\hline & A Course in English Pronunciation: A Generative Framework \\
\hline \multirow[t]{4}{*}{1997} & Idioms and Metaphorical Expressions in Translation \\
\hline & Selected Texts: A Reference Guide to the History of Iran \\
\hline & A Practical Course of English Phonetics and Phonology \\
\hline & Reading Comprehension III \\
\hline Total & 16 \\
\hline
\end{tabular}

Source: List of publications (SAMT, 2008)

components of the language (listening, speaking, pragmatics and discourse) remained absent from university ESP textbooks. In the continuum of approaches for TEFL, the Iranian ESP textbooks of the 1990s, without any doubt, fall at the grammar translation end of the continuum (for critiques of Iranian ESP textbooks, see Farhady, 1994; Kiany \& Khayyamdar, 2005-2006; Riazi, 2005a). Secondly, these textbooks appear to be intended to promote ideological knowledge about the virtues of the Islamic civilization and the unjust imperialism and arrogance of the West. To illustrate the ideological underpinning of these texts, an excerpt follows:

\section{The Prophet Muhammad (P.b.u.H.) and Western Civilization}

The Muslims form a nation over fourteen centuries old, and comprise, at present, more than eight hundred million human beings in all parts of the world. The prophet Muhammad (peace be upon him) was the first citizen of this nation, its teacher and its guide. He lived and died in the full memory of history [...]. Yet in spite of the wealth of historical facts available to us, perhaps no prophet and religion are so little known or understood by the Western world as Muhammad (P.b.u.H.) and Islam. The 
West, which has claimed now for several centuries a tradition of freedom of thought, a high grade of literacy, and boundless knowledge in all spheres of human learning, knows far less about Muhammad (P.b.u.H.) both as a prophet and as a leader of men who exercised a direct influence on the course of human events than about Alexander or Caesar, whose influences have been less than those of Muhammad (P.b.u.H.) and Islam.

What is the cause of such indifference in a world so eager to learn and to understand? Two explanations merit consideration. The first is from the pen of a distinguished Swedish scholar, who writes: 'The cause may perhaps be best expressed by the proverb: Relatives understand each other least of all. A Christian sees much in Islam which reminds him of his own religion, but he sees it in an extremely distorted form .... (Excerpt from English for the Students of Humanities II; quoted in Khazaifar et al., 2000: 28-29)

The mass production of locally produced English textbooks during the 1990s excited Iranian politicians and their supporters in their quest for an 'Islamic Republic' (jomuriye eslāmi) 'self-sufficient' (kod-kafä) from the West and the East (na shargi, na gharbi). The following comments, from a professor of English whom I interviewed, reflect this sentiment.

Back then in Iran we had our own issues and problems: the imposed war [with Iraq], coercion of the unjust imperialism and above all, the [economic] sanction [imposed by the US upon Iran]. Yet, we should be very proud of ourselves, as we taught a generation of students without importing a single English professor or teacher from elsewhere. That was in fact, our biggest accomplishment. When we talk about English in Iran, we have to consider that we have been sanctioned over years and because of that we had the chance to be reborn, for which I'm very happy. As a matter of fact, I long for even more sanctions. Because they let us stand on our own feet. Imagine you have a farm with a number of servants, whom you are in charge of feeding. So the responsibility is on your shoulder. But if you go away for a while and let them be in charge of feeding themselves, then, they could appreciate the food. That was how we began to appreciate English. (Interview transcript, Personal interview with an English professor, 16 January 2008)

In the view of students, university ESP courses at this time were among the most boring textbooks. As noted by Soleimani (2006: 216), the locally produced textbooks in use 'were published just to satisfy the perceived needs of the policymakers', but not the actual needs of the students. These shortcomings, in turn, led some professors of English to voice their concerns and criticism about the quality (Beh-Afarin, 2005) as, for instance, in the following excerpt, written 
by Professor Hossein Farhady (1994), an American-educated professor of English and an eminent figure in the field of English in Iran.

The current practice in ESP materials development in the country should be fundamentally redesigned. In order to prepare a textbook, need analysis should be conducted, specifications at different levels should be made, and appropriate materials should be developed. Otherwise, ESP programs designed on an unsystematic compilation of materials will not meet the requirement of any educational program in general, and our evolving and progressing academic community in particular. (Farhady, 1994: 80)

As with higher education, the epidemic of homegrown English curricula and textbooks entered the secondary school domain in the early 1990s. Whereas the purpose of university textbooks was to train students to use English for scientific purposes, school textbooks were meant to prepare students for the national university entrance exam, Konkur, which required no proficiency in communicative aspects of English but a high level of skill in grammar and multiple-choice tests (Interview notes, English teachers, School \#2, 3 May 2008). Two excerpts are provided below to illustrate secondary school teachers' perceptions of school English textbooks.

Teachers' perceptions of secondary school English textbooks

Excerpt 1

Teaching English at schools here is based on very old methods. The books have been used for years. But no changes at all! If one could only convince our policymakers, including those in charge of the Ministry of Education and Higher Education, that we need to change our schools curriculum, one would have done so much. (Interview transcript, English teacher, School \#1, 28 December 2007)

\section{Excerpt 2}

It is unfortunate to note that I have lost my proficiency and languageteaching ability in its totality. I have stopped language teaching for ages. What I actually do is to prepare students for the tests. It is this ability that they [the authorities] command. Since I am limited to the content of the books, and a few sample tests and test-taking techniques, I find no chance to use my professional knowledge and command of English. Well, you can't have something for nothing. I have gained recognition at the cost of my professional knowledge and expertise. (Quoted in Namaghi, 2006: 101-102) 


\section{International publishers, invisible lenders}

The foundation of the Tehran Annual International Book Fair in 1987 set the stage for the Islamic government in Iran to welcome international publishers, particularly those from the West. However, hostile attitudes towards foreigners, the Iran-Iraq War (which ended in 1988) and economic instability all had the effect of discouraging international publishers for the first couple of years.

With the rise of President Rafsanjani to power in 1989, the Islamic government began slowly to modify its antagonistic outlook towards the West. In his First and Second Development Plans, Rafsanjani set out policies to 'create a secure environment to attract foreign investors' into the country (Second Five-Year Plan, 1994). This change of attitude paid off; throughout the 1990s, the Tehran Book Fair developed an international dimension, attracting many foreign publishers, including Oxford, Cambridge, Longman, the Taylor \& Francis Group, Routledge, to name just a few. During this period, the Tehran Book Fair became virtually the sole point of contact with the international community for Iranian scholars, professors, students and book lovers. The following excerpt reflects the perceptions of an English professor about the role of the Book Fair in ELTrelated educational imports.

The Book Fair was the only place for us [English-language professors] to learn about the latest published books and research materials in our field. Back then, there was no internet, no access to e-books or e-journals. And so, the Book Fair was a big annual ceremony for us. Prior to going to the book fair, we would find its catalog to see what each foreign publisher had to offer in our area of specialization. Then, we would decide who should buy what. You know, the prices of foreign books were too high for us, comparing the US strong currency with that of ours.... We were not able to afford as many books as we wished to purchase. After paying our annual visit to the Book Fair, we would keep the purchased books on the shelves of our office to be used by students or to be lent to other colleagues. Often, handouts or copies of foreign books were prepared for class use. Although I do not have the luxury of having access to all books in the field of Teaching English, as my American and British colleagues may have, I can claim that I have almost all the important books written by prominent figures in our field. As a teacher, this is my duty to keep my students current with the latest findings in our field. And the Tehran Annual Book Fair has helped us to do so. (Interview transcript, TEFL professor, University \#5, 25 April 2008) 


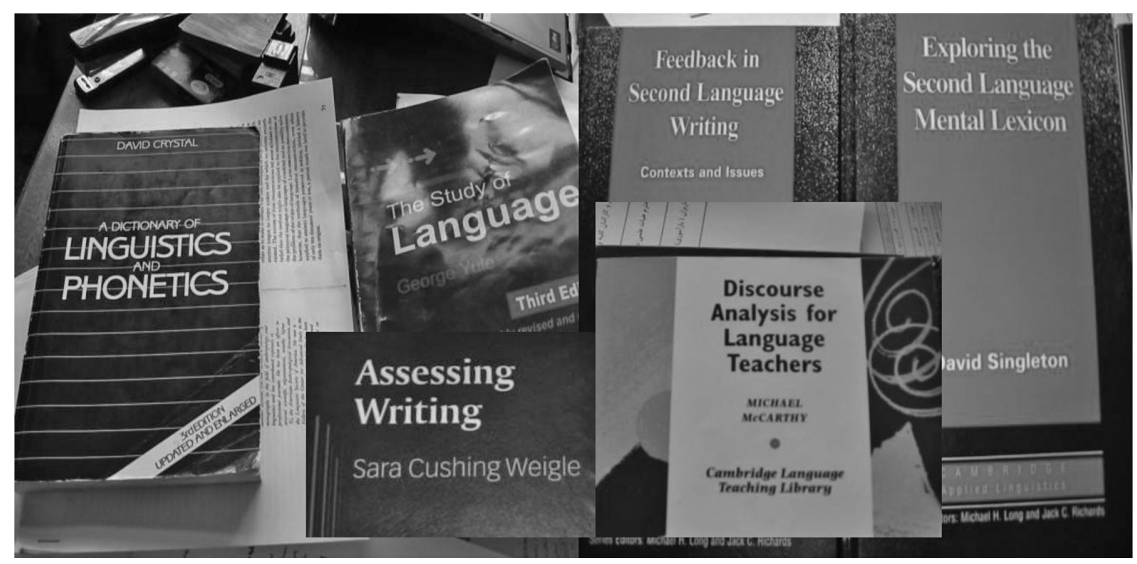

Figure 4.1 Examples of ELT books sold at the Tehran Annual International Book Fair. The figure illustrates the textbooks used by the above-interviewed professor for class instruction; the textbooks were sitting on his office desk during the interview, when the photo was taken. (Field picture, University \#1, Tehran, April 2008)

Although university courses in General English and ESP continued to be taught via locally produced textbooks, class reading materials in English departments of literature, translation and TEFL (as shown in Figure 4.1) continued to be borrowed from English-speaking countries, particularly via the Tehran International Book Fair.

\section{Private English Language Institutes, Agents of Internationalization}

We need to better understand the non-project nature of people's lives, the complex livelihood inter-linkages that make an impact in one area likely to be felt in others and the potential for unintended consequences arising from

any intended intervention or act.

Cleaver, 1999: 599

One of the most distinctive characteristics of English education in post1990 Iran was the empowerment of subnational forces: forces below the nation-state who have been, in turn, responsible for the importation of the 'international' model of English education into the country. It is true that the Iranian politicians of the time did not intend to empower the country's subnational forces nor did they intend to boost the importation of ELT practices from the English-speaking West to Iran, where the government had worked 
hard to remain isolated from the rest of the world since 1979. Yet one of the unintended consequences of the importation of the World Bank's economic policy of decentralization and privatization was the rise of the private sector.

Since the early 1990s, private English language institutes - which target fee-paying students (across all ages and proficiency levels) who desire to acquire English for their own personal reasons - began to be established on an unprecedented scale nationwide. It is unfortunate, however, that the Ministry of Culture and Islamic Guidance ${ }^{10}$ - in charge of giving work permits to private English language institutes - could not provide the exact number of these institutes over time. The only estimate provided was the following:

In 1996, there were around 2213 cultural-educational private institutes operating in Tehran, of which around 180 to 200 institutes were in the business of teaching English. Each institute was allowed to establish up to 100 branches. Yet, there are no statistics to tell us how many branches each private language institute had. And if there is an estimate I am not aware of it. As for the number of private English language institutes throughout the country, I'm afraid there is no estimate. (Interview transcript, Director of Work Permit Division, Ministry of Culture and Islamic Guidance, 17 February 2008)

Notwithstanding the absence of official statistics, some important inferences can be drawn from the interviews conducted with directors of private English language institutes. The Kish Language Institute had more than 40 branches throughout the country in the late 1990s. In the same period, the Shokuh Language Institutes had around 100 branches nationwide. Zabansara, another prominent language institute of the time established in 1990, operated only two branches in Tehran, in spite of the fact that it advertised itself as a representative of Oxford University and enjoyed much popularity (Zabansara, 2008). This limited estimate shows both the popularity of the English language among Iranian students and the widespread nature of private English language institutes (Field notes and interview transcripts, 18 December 2007 and 20 April 2008).

And this is what John Dewey regards as the power of youth in influencing education outcomes:

The young live in some environment whether we intend it or not, and this environment is constantly interacting with what children and youth bring to it, and the result is the shaping of their interests, minds and character - either educatively or mis-educatively. (John Dewey; quoted in Archambault, 1964: 9) 
There are two main reasons why the youth in Tehran and other Iranian towns showed so much interest in attending private English language institutes. The first reason was the failure of the country's state-run education establishments in offering proper English education. As discussed in the preceding section, high school and university curricula and textbooks were designed to promote little more than reading and grammatical skills. They did not prepare students to use the language to communicate or to be able to compete with their transnational counterparts in the global market economy. This shortcoming was particularly concerning to well-off families who wished to send their children abroad for higher education (Interview notes, English teachers, School \#2, 3 May 2008).

The second reason why the young people were attracted to private language institutions was the better services the private sector could offer them. This included an updated curriculum, international textbooks accompanied by audiovisual products, and proper teaching methods. Unlike their counterparts in the secondary and post-secondary education system, the private language institutes were allowed to design their own curricula and textbooks as long as they did not contravene the rules and regulations prescribed by the government. The private sector looked abroad for promising textbooks, curricula and teaching methodology. The result was the importation of English-teaching methodologies, including CLT, English textbooks, e.g. Headway and Interchange among many others, together with many audiovisual products from various English-speaking nations, the United Kingdom, in particular. This process was accelerated because Iran does not observe the copyright law for works (books and audio and video products) published abroad. Ayatollah Khomeini, for instance, is known to have issued a fatwa allowing a person who purchased a book to copy or reproduce it as his own property (Emami, 1993). Throughout the 1990s pirated foreign textbooks, dictionaries, audiovisual products and other instructional tools overtly entered the marketplace. Consequently, the private language institutes became the first agents of change with regard to English education in the Islamic Republic (Borjian, 2010).

A major private language player in the field of English education in postrevolutionary Iran is the Kish Language Institute, reputed to have pioneered the introduction of the British English textbook Headway (Figure 4.2) together with the CLT method and a student-centered teaching approach. The excerpt below is drawn from the interviews I conducted about Kish with the director of a private language institute.

Kish [Language Institute] was born in 1989 through the efforts of a group of innovative individuals such as Mr Sufi, within the Navy establishment in Kish Island [in the Persian Gulf]. Kish was a reaction 
Answer the ioliowing questions.

1 Why did he/she come to Britain?

2 What does he/she do?

3 Find one thing he/she likes about Britain, and one thing he/she doesn't like so much.

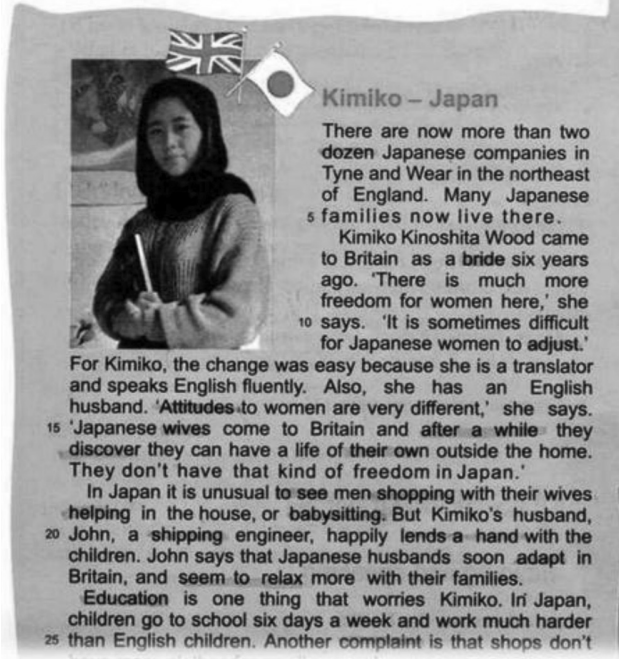

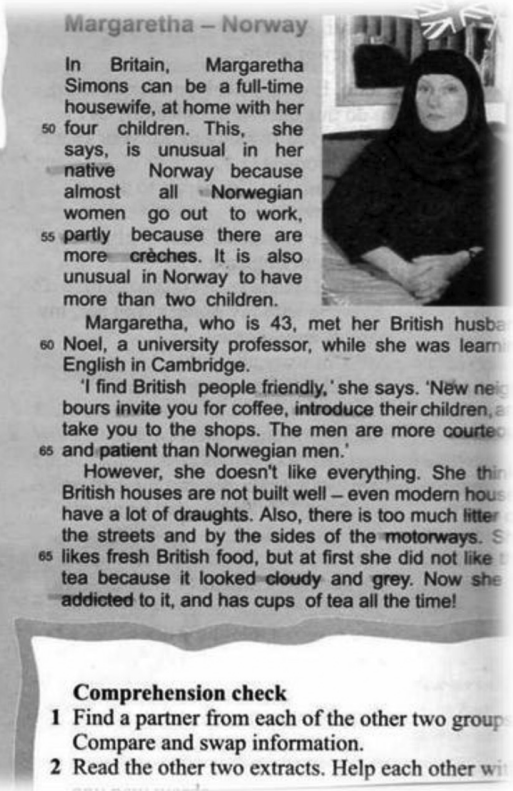

Figure 4.2 A page of a modified version of a pirated British textbook entitled Headway (John \& Liz Soars, 1996). The pictures of the women in the book were modified by the Ministry of Culture and Islamic Guidance to conform to the Islamic dress code. (Field picture, Tehran, May 2008)

to traditional ways of teaching English. In those days, the Grammar Translation method had dominated the country's English teaching discourse and practices. Kish was the first innovative institution with regard to teaching methodologies, textbooks and teacher-training standards in Iran. The innovative people in Kish wanted to teach English differently. They wanted to emphasize the communicative aspects of the language. Now, it can be claimed that Kish was a pioneer in bringing the CLT method and the Student-Centered Teaching Approach to the country. The idea of arranging classroom chairs in a circle or semicircle was first brought to the country by Kish. Other language institutions then followed in Kish's footsteps. So Kish has always been innovative. That is what Kish stands for. (Interview transcript, Personal interview with the director of Kish, 14 April 2008)

To prevent the wholesale borrowing of ELT materials from abroad, the Ministry of Culture and Islamic Guidance supervised the production of all 
pirated English books and audiovisual products in order to purify them of so-called 'unwanted' and 'undesirable' elements. The following excerpt illustrates the purification and Islamization process.

In the 1990s - well I think it is still very much the same - if we [a private language institute] wanted to use a pirated English textbook, we should have first found a publisher to cooperate with us. Then, the publisher would send a copy of the book we wanted to pirate to the Ministry of Culture. It would take the Ministry a good several months or even a year to examine the book. Then they would send the copy of the book back to the publisher with plenty of instructions in the margin, indicating what should be changed. Usually the Ministry was concerned about terminologies and pictures. For example, the terms such as a boyfriend, girlfriend, wine and other alcoholic beverages should have been changed to a brother, sister, milk, and tea. Additionally, the pictures in the books, especially those of the women, should have been modified to fit the Islamic dress codes. That was no problem when it came to the books. But we could not change the tapes or the videos. In the reading section, students would read about a brother and sister, but then in the listening section, they would hear that the two characters were boyfriends and girlfriends. That was quite funny! But we couldn't do much about it. We needed to comply with the rules. (Interview transcript, Director of private language school \#3, 8 May 2008)

\section{Conclusion}

This chapter has provided a detailed account of the political, economic and educational context of Iran during the presidency of Ali-Akbar Hashemi Rafsanjani, which we have referred to as 'the period of reconstruction and privatization' (1989-1997). During this phase, the Islamic government of Iran came to recognize the need to balance pragmatism and its initial revolutionary promises in order to maintain stability.

Under Rafsanjani, as has been shown throughout this chapter, Iranian politicians displayed some degree of receptiveness towards foreign lessons, ideas and norms, or what has been referred to as 'externalization'. But what were the causes of such a notable change in foreign policy? David Phillips $(2000,2004)$, one of the first scholars to pioneer research on policy borrowing, argues that there were various stimuli, including economic motives, political change or systematic collapse, internal dissatisfaction and negative external evaluation, among many others. Cross-national policy borrowing in 
Iran was driven by a wide range of factors: the failure of the country's economy following the massive destruction caused by the war, high inflation and unemployment. Political motivation for change intensified following the death of Ayatollah Khomeini and the rise of pragmatists to power, resulting in the adoption of the controversial policies of decentralization and the privatization of public institutions.

Throughout this period, the West continued to serve as the main 'reference society' for Iranian politicians, as exemplified by Iran's collaboration with the World Bank. Yet no explicit reference was made to the origin or source of the lending institution by the country's politicians due to their ideological, anti-Western and anti-World Bank sentiments. If one closely examines the First and Second Five-Year Development Plans of the IRI, one might assume that decentralization and privatization were homegrown innovations.

An unintended outcome of the new policy initiatives was the modernization of English education. Although the school curriculum (K-12) remained largely unchanged, privatization encouraged a decentralized curriculum at the private language institutes which were allowed to offer their own curricula and textbooks, while obeying the government's strict rules and regulations. The private sector thus participated in the educational decision-making process, albeit indirectly, on a limited scale, and within the constraints of a controlling government. It looked abroad to emulate promising ELT models and imported more modern English-teaching methodologies, textbooks and audiovisual products from various English-speaking nations, especially from the United Kingdom.

While the private sector was chiefly responsible for the transformation of the field of English in Iran, it would be misleading to assign absolute agency to subnational forces alone. The developments in the private sector were only made possible by the government policy of privatization. By extension, the policymakers would not have implemented this policy without pressure from the World Bank. In a similar vein, university professors of English would have not been able to buy the latest ELT textbooks, nor would the international publishers have been able to target Iran's isolated book market, had it not been for the Tehran Annual Book Fair, in turn initiated by the government to boost international cooperation - a strategy rooted in the Worlds Bank's 'structural adjustment' policy - itself an offshoot of neoliberal economic policy.

All things considered, therefore, in the 1990s internal circumstances contributed greatly to the transformation of English education and, subsequently, different sets of actors were involved in the process of transferring ELT standards, norms and 'best' practices to Iran. 


\section{Notes}

(1) The Second Development Plan (1995-1999) contains further details of the objectives and rules of privatization, of which the more strategic ones are: enhancement of people's participation; transferring part of state economic development and administrative activities to the private sector; expanding and strengthening the stock market; creating a secure environment for private investment; attracting foreign investment into the private sector and the cooperatives; reducing the size of government; and privatizing state enterprises (Second Five-Year Plan, 1994).

(2) It should be noted that relations between the Islamic Republic and the World Bank were halted in 1993, as the United States was able to sustain a coalition of G-7 countries that voted against World Bank lending to Iran (Weiss \& Sanford, 2008).

(3) One illustration of the qualitative decline of the country's education is provided by a study of 1983-1984 entry-level math students at Sharif Technical University, a top-ranking engineering school in Iran. The study revealed that in the 1983-1984 academic year, $30 \%$ of students dropped out and almost half of the remaining students had a GPA below 2.3. Further studies of the 1988-1989 entrants at the same university showed that nearly $38 \%$ of them failed their first-term Calculus while only $20 \%$ received scores of A or B. When the college performance of these students was compared with their GPA for the last year of high school, the study found that almost all of the weak students had a school GPA below $\mathrm{C}$. The interesting issue that is not addressed in the report is that only students with a GPA of B or above could enter Sharif University. The question as to why nearly $24 \%$ of the $1983-1984$ students entering this university had a GPA less than B reveals the fact that $24 \%$ of the seats were set aside for the so-called 'privileged social group', using Habibi's (1989) suggested term, which included members of the Revolutionary Guard and war veterans and their families, among many others.

(4) Iran witnessed a high rate of fertility with an annual rate of 3.4\% between 1976 and 1991. The country's population increased from 34 million in 1976 to 56 million in 1991 (Entezarkheir, 2005). This was, in turn, due to the dismantlement of Mohamed Reza Shah Pahlavi's Family Planning Laws (those of the pre-revolution) and their replacement with a new law drawn up on Ayatollah Khomeini's verdict that Islam and Iran needed a large population. Yet the IRI regime gradually began to realize that the costs of this population growth were growing too fast, exceeding its capacity to provide adequate food, education, housing and employment. As a result, starting from the early 1990s, during the presidency of Hashemi Rafsanjani, Iran's government began to modify its Family Law, declaring its preference for families with only two children (for more on this subject, see Abrahamian, 2008).

(5) Within the political structure of the IRI, the Council of Guardians refers to a body of eminent clerics (ulamā) who supervise the operation of the country's parliament and have the power to veto any 'un-Islamic' and 'unfit' legislation.

(6) The Ministry of Education of the IRI provided the following estimate for the number of private schools operating in Iran in the 1993-1994 academic year: 966 private primary schools, 829 middle schools and 430 secondary schools. In the same year, private primary schools enrolled 102,000 pupils ( $1 \%$ of total enrollment), middle schools 87,000 (slightly less than $2 \%$ ), and secondary schools 44,000 students (2.3\%) (Educational Statistics, 1994; cited in Mehran, 1997).

(7) While the education policies of the late 1980s and early 1990s kept pushing English to the margins of school and university curricula, favorable attitudes towards German 
began to be displayed by the country's politicians. At the request of Iran's government, the German Language Institute of Tehran (Anstitut-e Zabān-e Älmāni-e Tehran) and the Austrian Language Institute (Anstitut-e Zabān-e Älmāni-e Otrish) resumed their operations in Tehran in 1995, after a hiatus of 16 years. While few native English speakers were given visas to travel to Iran, native German speakers, together with their German-educated Iranian counterparts, were allowed to teach German to thousands of Iranians in Tehran. During the reopening term in 1995 alone, some 2200 students registered at the German Language Institute of Tehran (German Language Institute of Tehran, 2008). This number is, in fact, enormous for potential learners of a language that had lost its glory after World War II. Perhaps Iran's pronounced isolation from the world community, the excessive monopoly of the Islamic state upon the country's education system, together with the absence of native European speakers in the business of teaching foreign languages could be among the driving forces behind students' interest in attending the two German language institutes.

(8) Beginning in 1989, the IRI government displayed an enormous interest in educational cooperation at regional and international levels, as was reflected in the country's Second Development Plan of 1995-1999. However, collaboration with the West proved to be difficult, mainly due to conflicts with 'imperialism', which merely meant western Europe and the United States. Looking abroad in search of an educational organization whose goals and agenda were in accordance with those of the Islamic Republic, the Iranian politicians of the time came across the Islamic Educational, Scientific and Cultural Organization, known by its acronym ISESCO. Established in 1978, ISESCO aimed to establish an International Centre for Islamic Education that would conduct educational research along with other activities. It intended to make education in Muslim countries an 'authentic Islamic one', meaning an education model inspired by the Holy Koran and the Sunnah and also in tune with modern educational developments and concepts (ISESCO, 2008). The term 'authentic Islamic education' must have resonated well with Iranian politicians of the time, who chose to join the association in 1992. Regardless of their close collaboration, the Arabic curriculum remained intact in Iranian schools.

(9) Pre-university English is not a compulsory course. It was a prerequisite for EGP and it was designed only for those students who could not get a minimum score in English in the national university entrance exam, Konkur.

(10) This ministry has served as a vehicle for propaganda and censorship in the country ever since the foundation of the Islamic Republic in 1979. Soon after the establishment of the Islamic Republic, the pre-revolutionary Ministry of Culture was renamed the Ministry of Culture and Islamic Guidance. The ministry has been in charge of overseeing the publication of all sorts of books and audiovisual products within the country in order to purify them from so-called 'unwanted', 'undesirable' and 'secularliberal' content as well as from 'pro-Western', 'anti-Islamic' and 'anti-Islamic Republic' elements. In addition to purification, the Ministry has been in charge of the Islamization of the country by either publishing or funding state-run and privately run publishers to produce religious books. Every year, thousands of books enter the local market about the Koran, Islamic philosophy, religious figures, etc., which are either published or funded by this very ministry. 


\section{The Period of Global Outlook (1997-2005)}

Acquisition of knowledge, technology and skills are the most essential factors in achieving economic growth and development. Article 43, Fourth Five-Year Development Plan, IRI, 2005-2009

\section{Introduction}

This phase began with the election of Mohammad Khatami to the presidency in 1997 and lasted until the end of his second term in office in August 2005. During this phase, known as the reform phase, the political discourse of Iran witnessed a notable shift - moving from a pragmatic orientation towards a reformist one. Whereas reconstructing the war-ravaged country and rebuilding its ailing economy were the prime concerns of the previous administration (kārgozāraān), a call for 'moderation and tolerance' at home and a 'dialogue of civilizations' on the international scene was the main priority of the reformist administration (eslähtalabān).

As a reform-minded clerical politician, Khatami came to power with the promise of establishing an 'Islamic civil society', introducing 'religious democracy', 'respect for diversity', 'tolerance and moderation', 'rule of law' and 'freedom of expression', in the domestic arena ${ }^{1}$ - unprecedented values in the political discourse of the IRI. Such a reformist discourse appealed to the majority of Iranian voters, in the greater part women and youth and the rest of the silent majority. It is reported that some 20 million out of 30 million voters voted for Khatami in the 1997 election, which became known in Iran as the Epic of 23 May (hamāseye dovvom-e khordād). Despite strong opposition on the part of 
the more conservative members of the ruling elite, aka hardliners, Khatami was re-elected to the presidency in 2001 with 70\% of the vote (Mehran, 2003).

President Khatami's foreign policy was consistent with the declaration by the UN of 2001 being the UN Year of Dialogue Among Civilizations (goftogu-ye tamaddonhā). ${ }^{2}$ He argued that countries could learn from one another through dialogue, which would, in turn, replace their fears and prejudices with reason and tolerance. This was, in fact, an unprecedented change in the political discourse of the IRI. Concerning Khatami's perceptions of the West, Golnar Mehran (2003) writes:

Unlike the prevailing 'conspiracy theory' in Iranian politics, where the 'enemy' - usually the West - is at all times plotting to undermine national sovereignty, he [Khatami] looks inward to identify internal strengths and weaknesses.... His slogan, 'moving towards the future while leaning on the past', seeks to shape new relations with the West, one in which Western civilisation and advancement is not rejected but understood in terms of its merits and demerits. (Mehran, 2003: 321)

Such receptiveness towards the outside world and learning from other countries was also articulated by Mostafa Mo'in, the Minister for Higher Education (1997-2003) under President Khatami. In a speech he gave before the World Conference of Higher Education in Paris in 1998, he said:

We believe that this conference is a unique opportunity for decisionmaking in developing countries to acquaint themselves with the latest accomplishments in the area of higher education. ... To keep abreast of the latest developments in this field and to share experiences and exchange viewpoints will be a great step towards making universities become more relevant and responsive to the needs and demands of their societies.... We give high priority to international scientific cooperation and information exchange. I believe it is necessary for me to elucidate that the development of higher education is a necessary prelude to sustained development and serves as a comprehensive framework making social justice, mutual respect, democracy and human rights attainable and eventually facilitates the establishment of sustainable peace. (Mo'in, 1998; quoted in Majdzadeh-Tabatabai, 2006: 2)

This change in political discourse brought a new awareness of international cooperation on the part of the reformist ruling elite of the IRI. It was against this background that the IRI requested technical and financial assistance from various international organizations. 


\section{Partnership With Transnational Organizations}

Notwithstanding some improvement, the economy President Khatami inherited from his predecessor was marked by a high rate of inflation and unemployment (World Bank, 2001). The education system also faced many challenges. Relying upon the old revolutionary slogan of an 'Islamic Republic' (jomurive eslämi) 'self-sufficient' (kod-kafä) from the West and the East (na sharqi, na gharbi) was no longer of any use in the face of the profound socioeconomic problems. Certainly, Khatami's advocacy for a 'dialogue among civilizations', and his constant efforts to improve the image of the IRI in the international arena helped him to win the trust of foreigners. Such attempts paid off, and post-1997 Iran began to benefit, albeit behind closed doors, from the technical and financial support of international and foreign organizations, including the World Bank and various development agencies of the UN such as UNDP, UNICEF, UNFPA, UNODC and UNESCO (see also Borjian, 2011). ${ }^{3}$

\section{Partnership with the World Bank and the United Nations}

Between 1991 and 1993, as discussed previously, the World Bank played a major role in shaping the macroeconomic policy of Iran, by introducing privatization to the country. However, the relationship was temporarily suspended in 1993, when a coalition of G-7 countries voted against lending to Iran (Weiss \& Sanford, 2008) until May 2000 when loans were resumed. The overarching goal of the World Bank's partnership with Iran, as reflected in their Interim Assistance Strategy (World Bank, 2001), was:

To support the country's economic transition and structural reform agenda towards a more open economy, sustainable growth with improved income distribution. The Country Assistance Strategy (CAS) ... will recommend an integrated reform of Iran's oversized, inefficient and untargeted subsidies system to reach its objectives of growth and social justice. It continues the emphasis on supporting Iran's effort in rebuilding its physical economic infrastructure and building capacity for a knowledgebased economy.... The CAS will extend support to education, training and community-based development. (World Bank, 2001)

A further privatization of state-run organizations was embarked upon by President Khatami. During his eight years in office, he prepared his twin development plans: the Third Development Plan 2000-2004 and the Fourth Development Plan 2005-2009. In both plans, he called for economic reconstruction in a broader context of social and political development, which 
included expansion of policy decentralization and privatization. What was new and unprecedented, however, was the importation of the World Bank's 'knowledge-based economy' with its four underlying pillars, including having a sound institutional and economic regime, education system, telecommunications infrastructure and innovative sound education system (World Bank, 2011). As for the latter, it required a fundamental reform within the country's education system in order to link it to the country's economy, towards which Iran benefited not only from the expertise of the World Bank, but also from the technical and financial assistance of the UN.

In addition to the World Bank, starting from early 1999, Iran's social and economic reform was influenced by various developmental agencies within the UN. Available resources, both technical and financial, were mobilized to assist the Islamic Republic in embarking upon a systematic reform movement. The result of the first systematic evaluation project, embarked upon by UN Human Development and the PBO of IRI was Iran's first Human Development Report (UN, 1999). This report, the first of its kind, provided a comprehensive picture of the existing national development situation with regard to the economy, health and nutrition, women, the environment, drugs and education. It also proposed a set of policy recommendations for local politicians in order to achieve social and economic growth. Soon scores of collaborative projects between the government of Iran and different developmental agencies of the UN were launched. The result was the emergence of various reports written for the IRI. ${ }^{4}$

What all these reports had in common was their consistency in offering Iran a 'reform package', using Steiner-Khamsi's (2004) suggested term. They all emphasized the need to build the capacity for a knowledge-based economy, through expansion of information technology, proactive international collaboration and the improvement of national capacity in 'applied sciences', 'national scientific research capacities', 'information technology', etc. The reform package offered to Iran, however, was not country specific. It was, in fact, part of the 'global reform package' or what are called 'traveling policies' by Lindblad and Popkewitz (2004), which had traveled across the entire Middle East, Central Asia and post-Socialist countries throughout the 1990s. Iran was, in fact, a late adopter.

The excerpt below from one of the UN reports on education offers the reader a glimpse of what was proposed to Iran.

Quality education creates economic growth, according to how it is organized and how the capacities are allocated. Iran is facing the problem of students with degrees that leave the country each year because of the lack of appropriate infrastructures in universities and research centers as 
well as a lack of dynamic links between university and industry. ... It is important also to mention the missing link between industry, universities and research. The technological gap between Iran and advanced countries will be widening if this country doesn't reinforce its innovative capacity through quality education and appropriate fundamental and applied research capacities. (UN, 2004b: 13)

It is safe to presume that the global flavor of the country's Fourth Economic, Social and Cultural Development Plan 2005-2009 came from the various reports prepared by the UN developmental agencies for the IRI. Yet the implementation of the new 'reform package' was not the concern of the reformist president and his administration alone. In fact, it was an epidemic feverishly spreading throughout the country and attracting the attention of policymakers across different wings. In the summer of 2005, for example, the Council of Expediency (shorāy-e tashkhis-e maslehat-e nezäm) - headed by Ali-Akbar Hashemi Rafsanjani, the former president - prepared a Vision Plan (sanad-e chashm-andāz) for the country, in which long-term plans for the country were set to be achieved by 2025. In the Vision Plan, one of the eight goals to be achieved was to have an advanced scientific, academic and technological basis by 2025 (UN, 2004b: 13).

Such an overt preference for international collaboration was not, however, concealed from the view of the hardliners. While the reformists were in charge of the executive and legislative branches of the government, institutions such as the judiciary and the army remained in the hands of the hardliners - with the full support of the IRI Supreme Leader, Ayatollah Khamenei. This, in turn, limited the power of President Khatami for the best part of his two terms in office and, consequently, the domain of operation of foreign agencies in the country. A good illustration of such sectarian conflict came with attempts to implement the Third and Fourth Development Plans (1999 and 2004). The inclusion of many innovative policies in both plans led to serious opposition from the hardliners, and both plans had to be revised several times before they could be accepted by all forces within the ruling elite. Another example is the resignation of President Khatami's Minister for Higher Education, Mostafa Mo'in, who resigned from his post twice in 1999 and 2003. His latter resignation, as noted by Mo'in, was mainly due to his failure to convince outranking conservative authorities to redirect his ministry towards higher scientific productivity and higher collaboration at an international level (Borjian, 2011; Mo'in, 2004). Due to these profound sectarian conflicts, many policies set out in the country's Third and Fourth Development Plans remained merely at 'policy discourse' level and never materialized at 'policy implementation' level. 


\section{Transnational Education Model Production and the Expansion of English}

Higher education was the first sphere targeted for reform as it was assumed that this would prepare the ground for rapid economic growth and job creation. The two most notable reforms during this phase were the construction of research-based universities and the acquisition of communication/information technologies - both of which indirectly paved the way for English to renegotiate a new role in education, and higher education, in particular.

\section{Construction of research-based universities}

The higher education system President Khatami inherited from his predecessor was marked by excessive quantitative growth and a pronounced qualitative decline. It was seen by many as irresponsive and irrelevant to the needs of the country, which had long suffered from a high rate of unemployment and inflation (UN, 1999). With the purpose of finding solutions to the problems facing the economic and social sectors of the country, and with the help of his transnational partners, President Khatami set out new policies to promote the 'qualitative growth' of the country's higher education by transforming teaching-based institutions into research-based ones in the country's Third Five-Year Development Plan 2000-2004. The Ministry for Culture and Higher Education (vezärat-e varhang o ämuzesh-e 'äli) was renamed the Ministry of Science, Research and Technology (äezārat-e 'olum, tahgqiqāt o fannāvari) (Article 99, Third Five-Year Plan, 1999). The state became responsible for providing universities with access to national and international information, for increasing regional and international cooperation and for improving and promoting the latest technologies (Article 103). Updating the content of all fields of study was another top policy aim, as was transferring responsibility for academic planning to universities and institutions of higher education (Article 103). These new roles were seen as essential to achieve a more dynamic and competitive higher education system.

While the modernization of the English curriculum was not an explicit concern of either the UN development agencies or the World Bank, the global flavor of the proposed 'reform package' indirectly paved the way for English to carve out a new role within the country's education system. How could Iran improve its research capacity, employ new teaching methodologies and collaborate with its international counterparts in the areas of pure and applied sciences (as recommended, for instance, by UN, 1999, 2004a, 2004b), with low levels of proficiency in what was being hailed as the global language of research? 
An illustration of the growing awareness of the importance of English is provided by an article entitled 'English proficiency: a swift pace [sic] towards development', which appeared in the July 2003 volume of Nemud, the official journal of the General Office of Scholarship and Overseas Students, itself under the supervision of the Ministry of Higher Education. Equating English proficiency with economic, social and scientific growth, Nasrollah Afshar (2003), himself a state employee, writes:

Learning foreign languages, most notably English, has a direct impact on our country's social, economic and scientific growth. The question that may rise is: How is learning English related to our country's growth? ... It is related in several ways: it helps us to draw lessons from other countries' scientific and technological experiences; it helps us to use foreign academic-scientific textbooks and journal articles; it increases our productive use of internet communication; it encourages our [policymakers] to invest in higher education in a larger scale; and finally, it facilitates our scientific international cooperation with the world countries, especially with the developed ones. (Afshar, 2003: 13, author's translation)

Reflecting on the history of the country, Afshar (2003) makes a comparison between Iran's glorious past and an inglorious present. Although highlighting the country's magnificent scientific contributions to the Western world in the Middle Ages, the author blames the country's current stage of underdevelopment on its failure to catch up with the world of science, research and technology. In the author's view, English proficiency is essential for the country's economic growth. Detaching the language from its countries of origin, the author labels English 'the global language of science, research and technology', and blames Iranian education for its failure to produce a qualified labor force with a high level of proficiency in the language. The author goes on to recommend that the focus in English teaching should be broadened to include all four language skills, e.g. listening, speaking, reading comprehension and writing.

The Fourth Five-Year Development Plan 2005-2009 was the first policy document in which English gained currency as a key subject in the domestic educational arena. For the first time in the history of the IRI, the modernization of English curricula became an explicit policy goal. Section D of Article 52 of the Fourth Development Plan of the Islamic Republic reads:

With the purpose of ... enhancing quantitative and qualitative development of the public education, government is charged with the responsibility ... of enhancing necessary reform in the educational tutoring programs, 
deepening and improving teaching of mathematics, science, and English language. (Article 52, Section D, Law of the Fourth Economic, Social and Cultural Development Plan of the IRI: 2005-2009)

The importance of English as a global language also made its mark on secondary schools. The Organization for Educational Research and Planning within the Ministry of Education placed particular attention on upgrading the quality of locally produced English school textbooks. It is not surprising, therefore, to see the following excerpt on the cover page of all locally produced secondary school English textbooks starting from 2003, as shown in Figure 5.1: 'Learning English as a foreign language offers a means of knowledge, a mode of communication, and an instrument of judgment and growth'

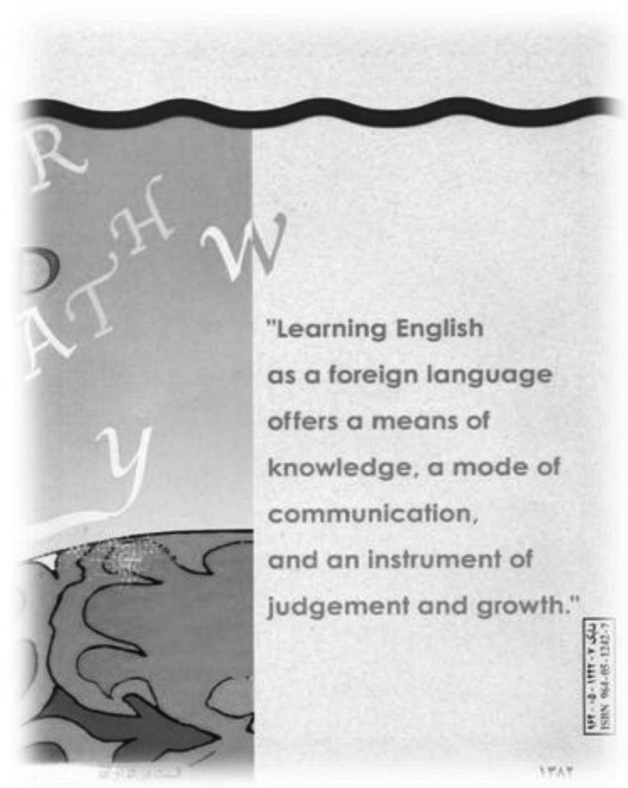

Figure 5.1 English Textbook for Sixth Grade (Ministry of Education of the IRI, 2003). Examining the content of this textbook and comparing it with those of previous years, it would appear that, except for the change in the cover page and few other minor changes, the content of this locally produced textbook is identical to those of previous years. This is a good instance of conflict between what politicians say, policy discourse, and what is actually being practiced on the ground. Many policies set in post-1997 Iran thus stayed merely at the policy level and have never been translated into practice, due to constant sectarian tensions within the ruling elite. (Field picture, Iran, January 2007) 
(English textbook for sixth, seventh and eighth grades, 2003). In addition, the start of English teaching, which had moved from the sixth to the seventh grade in the early 1990s, was now reinstated from the sixth grade.

It is true that the country's policy documents between 1997 and 2005 speak of significant attention paid by policymakers to the qualitative growth of the country's English education. It is true too that the policies set out in the Third and Fourth Development Plans paved the way for the expansion of English throughout the country. Yet many policies set out in the two plans stayed merely at a 'policy discourse' or 'policy talk' level, and have never had a chance to materialize and progress to 'policy action' or 'implementation'. For example, having examined the 1990 and 2000 editions of one ESP textbook entitled English for Students of Medicine (Deedari et al., 1990), it would appear that neither the Iranian ESP textbook compilers nor the policymakers felt the necessity for revision to make the book more current and relevant to the needs of students. The content of the two editions is identical, in spite of both the radical changes taking place in the field of medicine and the political discourse of the IRI. The main cause for this inaction is to be found in the excessive tensions between the reformists and hardliners within the IRI ruling elite. The recurrent instances of sectarian opposition and negotiation that shaped the policies of this period resulted in the failure to implement many aspects of the proposed 'reform package' in the public sector or in state-run educational institutions.

\section{Acquisition of new communication technology}

Another important driving force behind the expansion of the English language in post-1997 Iran was the increased access to communication technology in higher education made possible by the Third and Fourth Development Plans (2000-2004, 2005-2009). The central role of English on the internet during this period gave the language new momentum (Crystal, 1997, 2001). With the financial support of the government, universities began to equip themselves with computers and internet communication. Within a short period of time, major universities offered e-journals, e-books and e-databases, the majority of them in English. The digital revolution undoubtedly brought about radical change. It reduced the state's absolute monopoly over the content of university curricula and opened a new window of opportunity for educationalists to look abroad for new ideas, most particularly those in the field of English (Borjian, 2010).

Although the university courses of General English and ESP continued to be taught using locally produced textbooks, ${ }^{5}$ class reading materials in English departments of literature, translation and TEFL began to witness a 
drastic change. International e-journals and e-books began to replace the limited number of foreign textbooks, most of them outdated, as the main means of instruction. Iranian scholars and students of English began to read what their counterparts were reading in other parts of the world, and thus began to share similar professional concerns with their transnational counterparts.

University professors and researchers were not the only ones to benefit from exposure to the outside world via the English language. Based on UN data, the proportion of individuals in Iran with personal computers rose from 2,000,000 in 1996 to 7,347,000 in 2004. Yet in 2009 the number rose dramatically to include $30.2 \%$ of Iran's 70 million population. Likewise, the number of internet users per 100 inhabitants increased from $0.93 \%$ in 2000 to $7.49 \%$ in 2004 and to $13 \%$ in 2010 (International Telecommunications Union, 2008, 2011). To these we can add the individuals gaining access to computers and the internet via their universities, libraries, work places and internet cafés. Certainly, computers have broken down traditional boundaries and, together with the English language, made information accessible to a larger audience.

These developments did not fail to attract the attention of the conservative forces within the ruling elite. By order of the Supreme Leader of Iran, Ayatollah Khamenei (Letters No. 1/1033 and 1/1072), the Supreme Council of the Cultural Revolution passed a new bill (Regulation No. 488, enacted from November 2001) in favor of censorship. Warning of the subversive impact of the internet upon the people of the country, the new regulation assigned the task of purifying the internet from 'unfit' information to the Supreme Council of Information Technology (shorā-ye 'âli-ye ettelā resāni) and the Ministry of Intelligence (vezārat$\left.e^{\prime} e t t e l \bar{a}^{\prime} t\right)$. Everything perceived to go against the 'moral order', 'Islamic values' and the interests of the Islamic regime was prohibited and the links to these websites were blocked. ${ }^{6}$

\section{The British Council, Another Reference Society}

We support the establishment of links between educational institutions in Iran and Britain and can help interested institutions and individuals to establish a connection with the appropriate body in the UK. And why not attend a British Council Seminar in the UK, which gives you the opportunity for international networking. Website of the British Council Iran, December 2007

In 2001 the British Council Iran was invited by the IRI government to resume its work, after having been denied permission to operate in the country 
since the Islamic Revolution of 1979, on the grounds that it promoted imperialistic cultural and educational activities (for a detailed track record of the British Council Iran, see Borjian, 2011). Its office was officially opened to the public in the northern compound of the British Embassy in Tehran in October 2001 with 14 local and one American members of staff, and a British director, Michael Surgeon, who stayed in this position until early 2004. Under the direction of Surgeon, the Council could operate only in a limited way because of the tensions between the reformist and conservative politicians of the Islamic regime. It was not, for instance, allowed to offer English courses, as the revolutionary slogan of 'internal self-reliance' (khod kafäi-e däkheli) was still in place. Serious talks between the Council and the government began in 2004, with the arrival of a new director, Michael Wilson, which coincided with the preparation of the country's Fourth Five-Year Development Plan 2005-2009, in which upgrading school English curricula was one of the main policy priorities. The rise of a new awareness of English on the part of Iranian politicians laid the ground for the expansion of the British Council's operation in the country, in various domains, including ELT, professional networking and scholarships (Personal interview with British Council staff, Tehran, April 2008).

Although the Council was prohibited from offering English courses, it used every opportunity to promote the language. One way of doing this was to target English teachers for information. A project on the Training of Trainers (ToT) was designed to transfer the latest ELT pedagogical practices, methodologies, resources and materials to Iranian teachers of English. Various workshops were held in the Council's representation in Tehran, to which English teachers, professors and graduate students were invited. Trainers were British experts invited by the Council. What is provided below is information about two workshops organized by the Council for English teachers in Tehran in 2005.

\section{Two ELT Workshops in British Council}

Workshop 1, Sunday 4 December 2005

Subject: Creating a virtual learning environment. This workshop will provide you with some simple tools to help you get your classroom online and provide a safe space for your students to interact, share ideas and communicate.

Workshop 2, Monday 5 December 2005

Subject: ELT Online Resources. Finding good quality free lesson plans, articles and teaching ideas on the internet. This session will provide information about British Council and non-British Council sites which can support ELT development for English Language Teachers. Also, good 
sources of learning materials will be introduced for the usage of students of English.

For registration and exact times of the two workshops email us at: xxxx. (http://tefliran.blogspot.com)

The British Council was also interested in collaborating with the TEFL departments of local universities, a formidable task in view of the lack of autonomy even in internal affairs on the part of Iranian universities. Collaboration with foreign educational centers needed first to be approved by the government, requiring the Council to contact the university's Office of Foreign Affairs. The office would then contact the authorities in the Ministry of Higher Education who, in turn, had to contact the authorities who outranked the president and his administration to obtain permission. In spite of these obstacles, some successes were achieved, one illustration of which is provided below.

\section{Workshop on Material Development}

Place: Teheran, Tarbiat Modares University

Organizers: English Department, Tarbiat Modares University, TELLSI, and British Council

Trainers: Michael Rodden and James Chantry, both from Leeds Metropolitan University, under the supervision of Brian Tomlinson, Head of the Post-Graduate, Research and Consultancy Unit, School of Languages, Leeds Metropolitan University

Participants: Those interested, priority given to members of TELLSI

Cost: 350,000 Rials [US\$35]; depending on the performance (attendance, classwork, etc.) of the participants, some will get their registration fee back at the end

How to register: Visit TELLSI office at Tarbiat Modares University, Humanities...

For more information: $\mathrm{xxxx}$

What do you get at the end? A very good knowledge/skill on the issue, a certificate issued by TELLSI ${ }^{7}$ and the British Council, and (perhaps) your registration fee (who knows?).

(http://tefliran.blogspot.com)

In spite of strenuous efforts, however, the Council was never permitted to collaborate with public schools. It therefore began to work with the country's private language institutes, selling them English textbooks and audiovisual 
products and, in particular, materials related to the International English Language Testing System examination (IELTS) (see below).

\section{Test Your English Before Actually Taking the IELTS Test}

IELTS sample materials provide candidates with the opportunity to test themselves before they take the exam itself, to see if their English is at the level they require. The sample materials comprise a booklet together with a CD. The cost of each sample material booklet is 150,000 Rials [US\$15]. Please note the material booklet can be purchased at our office during normal enquiry hours.

A short selection of IELTS materials which may help you prepare for the Test:

A Book for IELTS (McCarter, Easton and Ash; Intelligence, 2000)

101 Helpful Hints for IELTS (G. Adams, T. Peck; Adams and Austen Press, 2000)

Cambridge IELTS 1 (V. Jakeman, C. McDowell; C.U.P., 2001)

Cambridge IELTS 2 (C.U.P., 2002)

Cambridge IELTS 3 (C.U.P., 2003)

Focus on IELTS (S. O'Connell, Pearson Education Ltd, 2003)

IELTS On Track (S. Slater, D. Millen, P. Tyrie; Language Australia Ltd, 2003)

IELTS Practice Tests 1 (J. Milton, H. Bell, P. Neville; Express Publishing, 2002) IELTS Practice Tests 2 (2003)

IELTS Practice Tests Plus (V. Jakeman, C. McDowell; Pearson Education Ltd, 2001)

IELTS Preparation and Practice: Listening and Speaking (W. Sahanaya, J. Lindeck; O.U.P., 2000)

(http://www.britishcouncil.org/iran.htm)

The greatest success of the British Council in post-revolutionary Iran came in 2005 when the Council was permitted to offer International English Proficiency examinations, such as IELTS, an exam required for emigration to countries including Canada, Australia and the United Kingdom. The Council was the only center for the IELTS exam in the country. Iranians who formerly had to go to neighboring countries to take this exam were no longer obliged to do so. The exam was offered once a week or once every two weeks at the Council's office in Tehran. According to the estimate provided by the director of the Council, every year around 150,000 people would take the test (Personal interview with the British Council Staff, Tehran, April 2008).

Another overarching goal of the Council's operation in Iran was making a connection between Iranians and their British counterparts. This was 
meant to promote professional networking. The following excerpt from the British Council's website illustrates that goal.

We support the establishment of links between educational institutions in Iran and Britain and can help interested institutions and individuals to establish a connection with the appropriate body in the UK. And why not attend a British Council Seminar in the UK, which gives you the opportunity for international networking. (http://www.britishcouncil. org/iran.htm)

One way to promote professional networking was to identify eligible candidates in a particular academic field and send them to the United Kingdom via the Council's scholarships and award programs. There were three types of scholarships: full scholarships, partial scholarships and British Council awards.

The full scholarship was designed to provide an opportunity for Iranian $\mathrm{PhD}$ and post-doctorate students to study in a university in the United Kingdom. The funding for this scholarship was provided by Britain's Foreign and Commonwealth Office (FCO) to cover expenses for up to two years. Between 2005 and 2007, around 54 Iranian students were sent to the United Kingdom on full scholarships (22, 19 and 14 individuals each year, respectively). The partial scholarships were designed for professors and graduate students to go to the United Kingdom for a short sabbatical or for research study. Covering travel expenses for up to six months, these scholarships were made possible by fundraising by the Council. Shell has been one of the most prominent partners in providing the funds for partial scholarships, offering between $£ 6000$ and $£ 10,000$ every year to the British Council in Tehran for four to 10 scholarships. Finally, the British Council award program was designed to provide an opportunity for Iranian academics to present their papers and become familiar with other professionals at international seminars and conferences held in the United Kingdom. A number of prestigious awards of £800-1000 to cover travel and expenses for up to a week in the United Kingdom have been made to between three and seven applicants per year (Personal interview with British Council Staff, Tehran, April 2008).

The Council has also worked closely with universities in the United Kingdom to provide study opportunities for Iranian students. The following excerpt illustrates such collaboration.

\section{Swansea University}

Swansea University extends a warm welcome to students from Iran and values their contribution to the community. We currently have a number 
of Iranian students studying at Swansea. Students from Iran are encouraged to enroll for English Language, International Foundation, and a wide range of Undergraduate and Postgraduate courses, including Engineering, Computing \& Software Technology, Communication Systems, MBA, Business Management, Law, and many more.

The University works closely with the British Council and its representatives worldwide. For additional advice on living and studying in the UK, please visit your nearest British Council office. (http://www.britishcouncil.org/iran.htm)

\section{The Rise of Professional/Elite ELT Networks}

One of the most distinctive characteristics of English education in post1997 Iran was the rise of university-based professional or elite networks able to direct their concerns to the country's politicians, thanks to the new policies on higher education adopted by the reformist politicians of the time. As already mentioned, the rise of information technology and access to internet communication also contributed greatly to the growth of the professionalization of ELT in the country.

Major efforts to professionalize the field of English education began in the late 1990s through the efforts of a group of professors of English, most of whom were foreign educated. The first movement for professionalization began at Tehran Teachers' Training University (dāneshgāh-e tarbiat-e mo'allem), through the efforts of M. Keshavarz, an American British-educated Iranian professor of English who, with the help of his colleagues, was able to establish the first Iranian Journal of Applied Linguistics (IJAL) in the later 1990s. Among the notable editorial board members of the journal, several names stand out: L. Yarmohammadi, H. Farhady, M. Ziahosseiny, Dabir-Moghadam and A. Riazi, to name but a few. The presence of these nationally known scholars, all foreign-educated Iranian professors of English, has been instrumental to the high degree of vitality in the journal. As of 2010, it had been published regularly and 12 volumes (a total of 24 issues) had appeared. The main contribution of the journal lies in its efforts to encourage local scholars to produce and write articles on various aspects of applied linguistics, such as curriculum development, teaching methodology, assessment, discourse analysis, second language acquisition (SLA), etc. (IJAL, 2008; Field notes and interview transcript, 29 January 2008).

Similar trends of professionalization also began to appear in the English departments of other universities. The best illustration is the foundation of the first and only post-revolutionary association of the Teaching 
English Language and Literature Society of Iran (known by its acronym TELLSI), through the efforts of an American-educated Iranian professor of English, A.A. Mirhassani and his colleagues at the English department of Tehran Instructors' Training University (dāneshgäh-e tarbiat-e modarres). This is the same revolutionary university that was once established to train pious and non-Western influenced professors. Since its foundation in 2003, TELLSI has organized nine national conferences on English education. ${ }^{8}$ Due to obstacles in the issuing of visas to foreigners, the TELLSI conferences have so far mainly attracted national rather than international audiences. Nonetheless, a few foreigners have been able to attend TELLSI conferences as keynote speakers. The most notable ones include Alistair Cumming and Vivian Cook from the universities of Toronto and London, respectively. Between 2004 and early 2006, TELLSI closely collaborated with the British Council representation in Tehran and organized various joint workshops on English-teaching related topics. In winter 2006, the association published its academic journal entitled the Journal of English Language and Literature Society of Iran. As of August 2011, four volumes of the journal have been published (a total of 10 issues). The association has currently around 700 members (Field notes and personal interview with TELLSI's secretary, 5 December 2008 and 15 December 2008; see also TELLSI, 2011).

Iranian foreign-educated elites are not the only ones who should be credited with the professionalization of the field of ELT in post-1997 Iran. Similar efforts have also been made by those whose learning and teaching experiences have never extended beyond the boundaries of Iran. One such individual is A. Tajeddin, the founding director of the journal of the Iran Language Institute (ILI), the former Iran-America Society. ILI Language Teaching Journal has been published since 2005 through the joint efforts of the ILI and Allāme Tabātabāi University. The main contribution of this journal to Iranian English education was to bring Iranian scholars, professors, teachers and students of English closer to their transnational counterparts. To do so, the editor began to correspond directly with his international colleagues and has been able to attract their contributions to the journal. Among the foreign contributors, some notable names stand out: Diane Larsen-Freeman (University of Michigan, USA), Dan Douglas (Iowa State University, USA), Lyle F. Bachman (University of California, USA), James Dean Brown (University of Hawaii, USA), David Nunan (University of Hong Kong), Andrew D. Cohen (University of Minnesota, USA), B. Kumaravadivelu (University of San Jose, USA) - all eminent figures in applied linguistics/TEFL in the world (Field notes and interview transcript, 26 January 2008; see also ILI Journal, 2008). 


\section{Implications of professionalization}

The main implication of the professionalization of the field of English education in post-1997 Iran was the rise of a coherent body of local experts who, through their association and journals, became strong enough to voice their concerns about the low quality of English education offered in schools and universities. A good illustration of such a collective act is the First National ESP/EAP Conference organized by the foreign languages department of SAMT (the state-run publishing company in charge of the production of locally produced textbooks), headed by Gholam Reza Kiany, also the director of the TEFL department of Tehran Instructors' Training University. The First National ESP/EAP Conference was held in Tehran on 24 April 2005 and broadcast by Iranian National Television. The proceedings of the conference were published in a three-volume book (Kiany \& Khayamdar, 2005-2006), in which around 46 papers and 11 lesson plans were presented.

Most of the papers presented at the conference made extensive reference to global ELT concepts - CLT, authentic materials, discourse and genre analysis, learning strategies, process-oriented assessment, need analysis and studentcentered teaching, among many others - in order to highlight the drawbacks of locally produced ESP textbooks as well as to legitimize the need for reform. Relying upon the global ELT literature, some scholars used externalization as a means to question the outdated methodology promoted in local ESP textbooks and to call for the replacement of the old methods with new ones.

In recent years, English language teaching overseas has taken on a new character. ... What is needed in EAP [English for Academic Purpose] courses [at home] is a shift of focus from the grammatical to the communicative properties of the language. (Karimkhanlui, 2005: 58-60)

Others made reference to the global ELT literature to criticize the reliability and authenticity of homegrown ESP materials. In his presentation on 'The features of quality EAP textbooks: insights from literature and book reviews', Abdolmehdi Riazi, English Professor at Shiraz University, discussed the features of a good ESP textbook. One such feature that was missing in local books is discussed in the following excerpt:

As related to the content of textbooks, it is expected that the materials be chosen from among the authentic texts and materials to expose students to the real-life type of texts. (Riazi, 2005b: 41)

Still others looked at 'externalization' from a language planning perspective to criticize the highly top-down, institutionalized and centralized policies of 
the government. Doubting the relevance of globally produced materials to the needs of students at home, Yarmohammadi argued that centrally produced materials, like those of the ESP textbooks published by SAMT, could also be irrelevant and irresponsive to the needs of students. Thus he urged for more autonomy on the part of teachers:

Globally or centrally produced materials cannot cater to all the needs of our universities and institutions, or individuals. This is an obvious fact. Thus, some room should be left for supplementary materials to be provided by universities, departments, individual teachers. (Yarmohammadi, 2005: 18)

Yarmohammadi went one step further to urge Iranian professional elites to concentrate their efforts on making their voices heard by the politicians of the country:

We have two associations, already in operation: the Association of Linguistics and the Association of Language Teaching. These two should get together and draft appropriate research and policy proposals to submit to the academies, the Ministries, the Supreme Council of Cultural Revolution and Parliament. ... The matter is strategic to our national development. (Yarmohammadi, 2005: 17)

After three decades of experience, Iranian ESP curricula and textbooks still suffered from various inadequacies, judging by the papers presented at the country's First National ESP/EAP Conference in 2005. The question as to whether the concerns and criticisms raised by professional elites at the conference have ever been heard by the country's politicians will be a topic of investigation in Chapter 6.

\section{The Expansion of Private Language Institutes}

As was the case in the previous phase, private language institutes played a vital role in expanding English education as well as in importing ELT materials into the country in post-1997 Iran. According to an estimate provided by the Ministry of Culture and Islamic Guidance, there were around 2200 private English institutes (excluding their representations and branches) throughout the country in 2003 (Interview transcripts, Director of Work Permit Division, Ministry of Culture and Islamic Guidance, 17 February 2008). This expansion caused a dispute between the Ministry of Culture and 
Islamic Guidance and the Ministry of Education, about their respective spheres of influence. The dispute reached its peak in early 2003, to the extent that the Supreme Council of the Cultural Revolution passed a new regulation (No. 513, 10 March 2003), whereby it has been decided that the Ministry of Education should supervise private English institutes for K-12, whereas the Ministry of Culture and Islamic Guidance should be in charge of private language institutes for adults.

\section{Direct versus indirect borrowing}

Private English language institutes became agents of change and innovation in several ways. One such way was by the direct borrowing of ELT practices from English-speaking nations through close partnerships between local language institutes and foreign ones, most notably British. In such cases, the language school advertised itself as the only countrywide representative of a foreign English language center or of the English department of a foreign university. Foreign-driven textbooks and curricula were used to attract fee-paying students. Moreover, foreign experts would occasionally be invited to the school to offer workshops on different aspects of teaching and learning English to local teachers and students.

An instance of such direct borrowing might be the partnership between Aryanpour Language Institute and the English Department of Cambridge University. As the representative of Cambridge University in Iran, as was claimed locally, Aryanpour was permitted to offer CELTA (Cambridge English Language Teaching to Adults) certificates to thousands of Iranians aspiring to be English teachers. Another instance of such collaboration was that of the Kish Language Institute and Cambridge University between 1999 and mid2005. During these years, Kish advertised itself as a sub-center of the English Department of Cambridge University, and offered the ESOL exams KET (Key English Test), PET (Preliminary English TEST) and CAE (Cambridge Certificate in Advanced English), among other proficiency tests (Figure 5.2). As one of the few language schools throughout the country, Kish was officially permitted by Cambridge University to offer these exams in Iran (Interview transcripts, Directors of private language institutes \#1 and \#3, 14 April 2008 and 8 May 2008).

It should be noted that such collaboration did not take place at the state level and thus did not involve either Iranian politicians or their foreign counterparts; nor were partnerships the result of coercion by supranational forces. In fact, such partnerships stemmed from below, the result of the efforts of a group of Iranian individuals, most notably the directors of private language schools who, for motives such as attracting fee-paying students, began to 


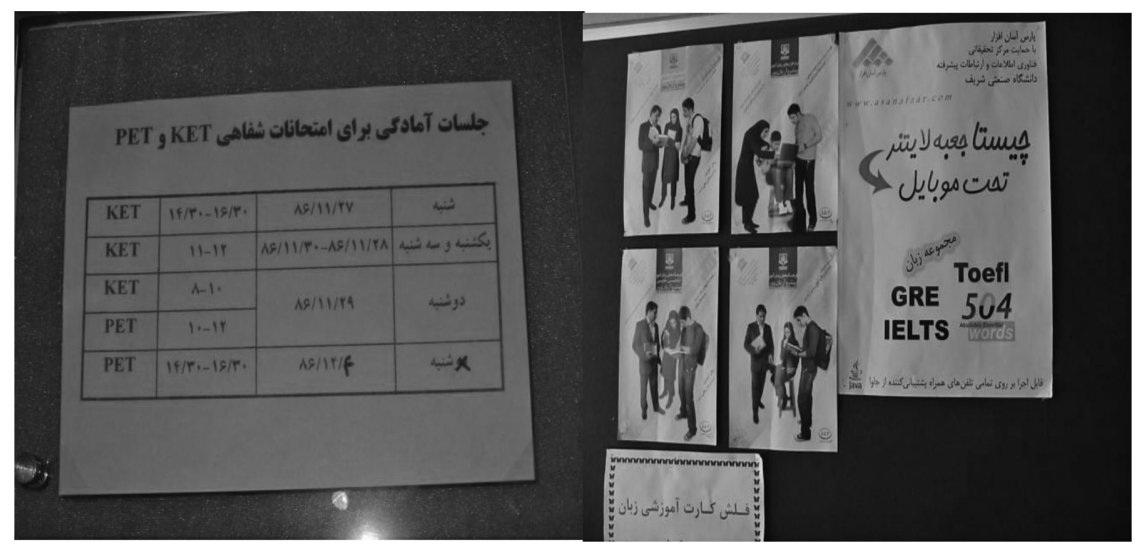

Figure 5.2 Fliers for KET, PET, TOEFL, IELTS and GRE examination preparation courses from the bulletin boards of private language institutes (Field pictures, Tehran, May 2008)

borrow ELT practices and textbooks voluntarily from abroad. The following excerpt illustrates the process of establishing such a partnership between a private language institute and ELT Banbury (UK).

Well, we traveled to Oxford University to get in contact with its ELT Center. There we became friends with DrX, the director of ELT Banbury, itself one of the 23 faculties of Oxford University. We invited Dr X to Iran to visit our language center. He traveled to Iran more than three times and visited our institutes and gave a series of lectures to our students and teachers. Based on his close observation of the performance of our school, we were able to secure his trust, and thus, he offered the institute the permission to give the certificate of ELT from Oxford University. It should be added that we have been in a regular contact with $\operatorname{Dr} \mathrm{X}$, and we have been giving this certificate since then. (Interview transcript, Director of private language school \#4, 10 May 2008)

The certificate granted to this private language institute by ELT Banbury in July 2005 hung on the wall of the office of the director of the institute when I conducted my fieldwork.

This is to certify that Dr. $\mathrm{xxx}$ and $\mathrm{xxx}$ Language Center, Tehran, Iran, is the nominated and exclusive representative of ELT [sic].

Signed by: Dr. Terence Gerighty,

Director of ELT Banbury 
Date: July 2005

ELT Banbury is accredited by the British Council.

(Field picture and field notes, Private language institute \#4, 10 May 2008)

Apart from direct borrowing, many private language schools borrowed ELT practices from English-speaking nations indirectly. This indirect type of borrowing did not involve any kind of partnership between a local private language school and its foreign counterparts; nor did it involve foreign delegates coming to assess the performance of the local institute. Rather, it consisted mainly of pirated foreign English textbooks, audiovisual products and teaching methodologies, judging by the content of the curricula and textbooks used in such language institutions (see Figure 5.3).

\section{Real versus phony collaborations}

As in the case of professional or elite networks, Iranian private language institutes used 'externalization' or lessons drawing from elsewhere as part of their agenda, that is, to attract fee-paying students. As a result, in post-1997 Iran, many private language institutes advertised themselves as representatives of foreign universities. Such claims could be either real or phony and it is sometimes difficult to draw the line between the two. Compare, for instance, the website of Zabansara, a prominent English language center in Tehran (Figure 5.4), with the Wikipedia entry on the same, possibly written by a rival language center.

\section{Excerpt 1}

Zaban Sara Foreign Language School is a most successful provider and supplier of ELT books, tapes, video cassettes and CDs. We are also very proud of being the exclusive representative of the Oxford University Press (OUP) in the country. Our over-riding priority is to provide higher standards of quality education at a reasonable price. In order to maintain its standards, Zaban Sara regularly holds international and domestic seminars and workshops on ELT. (Zabansara, 2008)

\section{Excerpt 2}

Zabansara ... had also obtained a license for publishing books from Oxford University Press. The publishing license however, was taken away from them after they had falsely claimed to be the Oxford University Representative in Iran. Unauthorized copies of copyrighted OUP materials were also found. Surprisingly, xxx, the founder and president, cannot even speak English. 

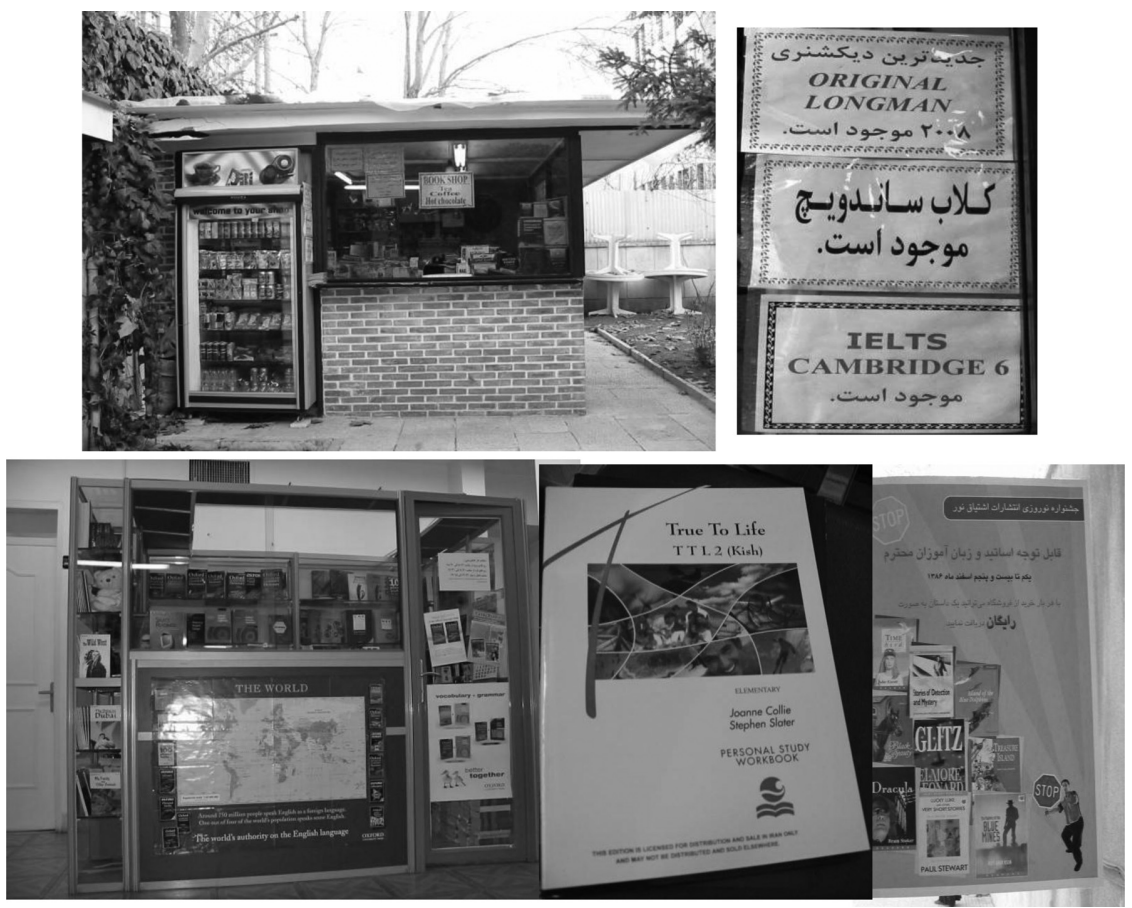

Figure 5.3 Inside private language institutes. The picture on the top left shows the window of a school cafeteria displaying several fliers in English-Persian; three of them are magnified in the top right picture, advertising the availability of an original Longman 2008 Dictionary, a club sandwich and IELTS Cambridge 6, respectively. The picture on the bottom left shows a school book store with many original foreign English books, including True To Life. The picture on the bottom right, taken from a bulletin board of a private language institute, is a buy-one-get-one-free flier, indicating that if one buys one of their foreign English textbooks they will get an English story or novel for free - all instances of unprecedented acts of commercialization in the IRI. (Field pictures, Tehran, 2008)

In the case of the Iranian-Australian and Iranian-Canadian schools of foreign languages, things are more clear-cut. The students who attend these institutes with whom I had the opportunity to talk assumed that these were the official representatives of a Canadian or Australian educational center in Iran, like those of the pre-revolutionary associations of Iran-America and the British Council. Yet when I approached the Canadian and Australian embassies, I was told that neither nation was involved in any type of cultural or educational activity in the Islamic Republic. Their foreign-driven designations 


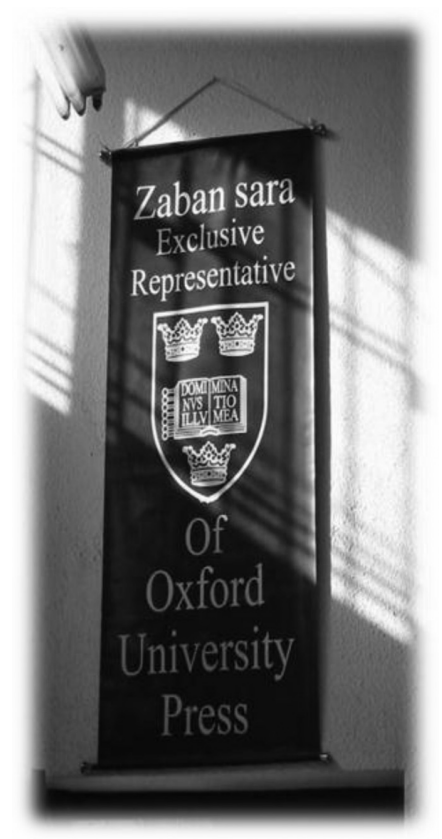

Figure 5.4 Zabansara Language Institute (Field picture, Tehran, November 2007)

were chosen deliberately by such institutes to meet their own agendas, most notably to attract fee-paying students.

\section{Contributions of private language institutes}

Iranian private language institutes should be given credit for their subtle but constant resistance to the state's top-down educational policies in several ways. Firstly, these institutes reduced the government's absolute monopoly, for example through the mass importation of pirated textbooks, especially since mid-1997. Whereas the ministry revised the content (and illustrations) of all pirated foreign textbooks in earlier phases of the history of the Islamic Republic, they have since come to recognize that such a pursuit is time-consuming, costly, ineffective and, above all, unmanageable. As a result, since early 2000 pirated foreign textbooks are no longer subject to revision. Secondly, since English was not taught in primary schools, private English institutes were instrumental in introducing English at pre-school and primary school levels. And finally, private language institutes, in collaboration with foreign centers, prepared students for international English tests, such as the KET and PET 
Cambridge proficiency exams and CELTA. Had Iranian students wanted to take these tests previously, they would have needed to go to neighboring countries (Interview notes, English teachers, Private schools \#1 and \#2, 2 December 2007 and 3 May 2008; also Interview notes, TEFL students, University \#5, 25 November 2007).

\section{Conclusion}

This chapter offers a detailed account of the social, political, economic and educational context of the IRI under the administration of Mohammad Khatami (1997-2005), the reform-minded president of Iran, whose domestic and foreign policies were shaped around the slogans of 'civil society' and 'dialogue among civilizations'.

It is reasonable to argue that, during this phase, forces at national, subnational and supranational levels contributed equally, either directly or indirectly, to the internationalization of ELT in Iran. The first catalyst came from within the country. The reformist administration, unlike their conservative counterparts, showed an enormous interest in dialogue with the world at large and in building capacity for international cooperation in the social, economic and scientific arenas. This change in attitude was due in part to internal dissatisfaction with the economy and education and in part to the negative evaluations of international organizations. Reformists were able to use these shortcomings to demonstrate the urgency of a fundamental reform at home and to justify looking abroad for promising solutions. As such, the first actors who set the stage for policy borrowing, and indirectly paved the ground for the internationalization of English education in the country, were certainly the country's politicians.

The result was a partnership with two major transnational organizations, the World Bank and the UN - both known not only for lending their financial resources to developing and underdeveloped nations but also for their 'best' educational models and practices (Jones, 2004). It was through a partnership with these institutions that a global reform package, focused on a 'knowledge-based economy' and further expansion of 'policy privatization and decentralization', was exported to the country as a solution to its socioeconomic problems.

In education, the intention was to build the capacity to transform the country's universities from 'teaching-based' to 'research-based' institutions, equipped with computers and communication technologies. The unintended consequences, however, were numerous. The empowerment of subnational forces, both university-based professional networks and private language 
institutes, weakened the state's absolute monopoly over education. As part of the same process, English - the former language of the enemy - was able to renegotiate a role very different from that projected by the founding leader, Ayatollah Khomeini, in 1979. As the reform discourse was pushed forward, politicians looked increasingly outwards. They extended an invitation to the British Council, their old foe, for collaboration in several domains, ELT included, in a country where no other rivals from the English-speaking West (and the United States in particular) had been granted such permission.

The rise of information technology and access to internet communication, a pillar of the 'knowledge-based economy', also contributed greatly to the professionalization of English education. One consequence was the rise of a body of local experts who, through their associations and journals, became strong enough to voice their concerns about the shortcomings of 'indigenized' English education. Through publishing and conference presentations, professional elites used foreign ELT models to highlight the drawbacks of the IRI English model and to underline the need for reform. Private English language institutes were another influential group. As was the case for their academic counterparts, they used foreign materials and ideas to meet their own needs.

In addition to multiple agents, multiple causes were involved in the transfer of global policies to Iran. While the main driving force for reformist politicians was the quest for economic and social development, the main concerns of subnational forces (professional networks, private language institutes, etc.) were professional (achieving a higher academic rank on the part of professors), or economic (attracting fee-paying students on the part of private language institutes), political (resisting the top-down pressures of the state and arguing for a policy change at home, as was the case for English professors), or personal (gaining exposure to the outside world on the part of students). The catalysts for supranational involvement (the World Bank, the UN and the British Council) were numerous, but the most notable is perhaps economic gain, as policy transfer is a lucrative business for foreign experts and consultants (Robertson et al., 2002; cited in Steiner-Khamsi, 2004: 205).

\section{Notes}

(1) The term 'civil society', which originated in the West, refers to voluntary civic and social organizations and institutions that form the basis for a functioning society as opposed to the force-backed structures of a state. Civil society served as an important pillar of Khatami's political thoughts, as he sought to combine the tenets of an Islamic order with the Western concept of a civil society. As a clerical leader, he wanted to ensure the coexistence of religion and state, in what he called the 'Islamic civil society', based on 'religious democracy' (Khatami, 2001: 134; cited in Mehran, 
2003: 317; also for a collection of Khatami's speeches, see La'li, 1999). On the 'rule of law' and 'freedom of expression', Khatami argued that a truly strong government is one that recognizes the legal rights of its opponents and forcefully defends those rights (Khatami, 2000; cited in Mehran, 2003: 318).

(2) For more on Kofi Annan's suggestions about dialogue among civilizations, see http:// www.un.org/Dialogue/background.html.

(3) On the cooperation of each of these organizations with the IRI, see the official website of each institution, on which various reports are available free of charge, including: UNDP at http://www.undp.org.ir/; UNICEF at http://www.unicef.org/ infobycountry/iran.html; UNFPA at http://iran.unfpa.org/; UNODC at http://www. unodc.org/islamicrepublicofiran/; UNESCO at http://www.unesco.org/new/en/ unesco/worldwide/unesco-regions/asia-and-the-pacific/iran-islamic-republic-of/; and the World Bank at http://www.worldbank.org/en/country/iran.

(4) To name a few: United Nations Common Country Assessment (CCA) for the IRI (August 2003), United Nations Development Assistance Framework (UNDAF) (2005-2009) for the IRI (September 2004), The First Millennium Development Goals (MDGs) Report: Achievements and Challenges (November 2004).

(5) The track record of university English textbooks published by SAMT between 1997 and 2005 includes 77 books, of which 68 were ESP and nine were English literature, translation and TEFL.

(6) Two years later, the Supreme Council of the Cultural Revolution went one step further and passed another regulation (No. 526, in effect from October 2003), in which the Supreme Council together with the Organization for Islamic Propaganda were included in the committee in charge of the purification and Islamization of internet communication.

(7) TELLSI stands for the English Language and Literature Society of Iran. Established in 2003, TELLSI is the first and only professional association of English academics ever established in post-revolutionary Iran. Its predecessor was the Association for Professors of English (1974-1984), founded through a collaboration between the English department of UCLA and its Iranian counterpart, the English department of Tehran Teachers' Training University (Dāneshgāh-e Tarbiyat-e Mo'allem).

(8) The TELLSI conferences were held at: Tehran Instructors' Training University in February 2004; Tehran University in February 2005; Razi University in Kermanshah in February 2006; Shiraz University in February 2007; Gilan University in February 2008; Yazd University in October 2009; Al-Zahra University in October 2010; and finally Ilam University in October 2011. 


\title{
6 Returning to Revolutionary Roots (2005-Present)
}

\begin{abstract}
Some people [meaning the reformist fraction of the IRI government] keep saying that our revolution is aimed at establishing democracy [mardomsāläri]. No neither in the Imam's [Ayatollah Khomeini] statements nor in the message of the martyrs ... has any such idea been considered.

Mahmoud Ahmadinejad, IRI President, 2005; cited in Arjomand, 2009: 150-151
\end{abstract}

\section{Introduction}

In this final phase, which began with the election of Mahmoud Ahmadinejad to the presidency in August 2005 and continues to the present day, the political discourse of the IRI has witnessed a notable turn - moving from a reformist position to a conservative one, crafted, regulated and supported by osulgarāyann (hardliners or fundamentalists), meaning those who remain completely faithful to the fundamentals of the IRI, underpinned in 1979 by its founding father, Ayatollah Khomeini.

Ahmadinejad, an osulgara, came to power with the promise of creating an exemplary government, based entirely upon the early revolutionary doctrines. Such aspirations, together with his advocacy for 'social justice', 'equity', 'eradication of poverty', 'corruption' and, above all, the 'distribution of petroleum income among the dispossessed' (mostazafin) resonated well with low-income and religious conservatives in the June 2005 presidential election campaign. Among his other most enthusiastic supporters were the members of the Army of the Guardians of the Islamic Revolution (sepäh-e päsdārān-e enqeläb-e eslāmi), better known as the Revolutionary Guards, and its mobilization arm, the Basij. Despite strong opposition on the part of the reformist members of the ruling elite and their supporters, Ahmadinejad was elected as President of the IRI in 2005. His second electoral success came in the June 2009 disputed presidential election, which is viewed by the opponents as an 'electoral coup 
d'état by the Revolutionary Guards', the most enthusiastic supporters of Ahmadinejad at the time (Arjomand, 2009). The result of the election was immediately disputed and led to protests from millions, aka the Green Movement, whose members were either the supporters of the reformist candidates or the silent majority, who had long been skeptical about participating in the IRI's elections but longed for a fundamental political change. These demonstrations were immediately suppressed by the government. Their official justification was to claim that the demonstrations were supported by external forces, having their roots in the West, who aimed at plotting a 'velvet' or 'soft' revolution in Iran to throw out the Islamic government. The demonstrators, on the other hand, claimed that all they wanted was to get their votes back.

With the ascendency of Ahmadinejad to the presidency in 2005, hardliners have taken control not only of the executive branch but also of the legislative and judicial branches of the IRI government. Conservatives also continue to control the Revolutionary Guards and the Basij. As a result, reformists were not only entirely eliminated from the ruling elites, but also many elements of reform have been reversed. The principles of 'freedom of expression', 'democracy' (mardom-sāläri), 'tolerance' and 'respect for diversity', advocated by the former president, Mohammad Khatami, have disappeared from the domestic political discourse and have been replaced with the discourse of the 'Hidden Imam' - Mahdi, or the Twelfth Imam, believed to be in occultation until he returns as a Messiah at the End of Time, as eagerly anticipated by Ahamadinejad.

Our revolution's main mission is to pave the way for the reappearance of the Mahdi. Today, we should define our economic, cultural and political policies on the basis of the Mahdi's return. (Ahmadinejad's speech; cited in Arjomand, 2009: 156)

Ahmadinejad's foreign policy was crafted around several slogans, the two most notable of which - a nuclear Iran and combating Zionism - both pushed the nation further into international isolation. Nonetheless, it brought Ahmadinejad a great deal of admiration in the streets of many Muslim nations, the Arab world, in particular.

\section{Education and the Re-indigenization Movement}

Higher education was the first sphere to undergo a radical ideological transformation, as part of hardliner attempts to revive the early revolutionary principles. This was achieved by re-embracing the two pillars of the IRI's early 1980s Cultural Revolution (1980-1982): 'purification' and 'Islamization'. 
In a speech delivered at the Amir Kabir Technological University in fall 2006, Ahmadinejad promised to eradicate all 'Western and vulgar' values, by which he, as has been widely understood, meant liberal and secular influences in higher education. University students protested but were quickly suppressed by Basiji militiamen, who occupied the universities. Purification in academia was carried out by appointing hardliners to key positions. The most astonishing example was perhaps the appointment of Abbas-Ali Amid Zanjani, a cleric with a humble educational background (a high school diploma), to the chancellorship of Tehran University, the oldest and most prestigious university in the nation. Further purification was said to be carried through 'the early retirement campaign', the premature retirement of professors who opponents said were all 'liberals'. In November 2006 at the University of Science and Technology ('elm of san'at), as many as 53 faculty members were encouraged or, as opponents may say, forced to retire. The retirements or purges of professors were completed by the end of 2006 (for further discussion, see Harrison, 2006; Irani, 2006; Rooz, 2006; Tait, 2006).

In addition, purification measures were taken to promote the 'indigenization' and 'localization' of knowledge in higher education as a means to combat 'globalization', the new form of 'Westernization'. Fearing the harmful impacts of globalization, the government began to organize and fund conferences and seminars to highlight the requisite strategies for producing indigenized knowledge and resisting the destructive impact of globalization. The following excerpts, posted on the bulletin board of a university in which fieldwork was conducted, are two such instances.

In the Name of God

Date: 1 September 2007

Dear Mr. Dr. xxx, Director of the Faculty of Persian and Foreign Languages and Literatures:

Since the indigenization of the field of Humanities is one of the main concerns of the Islamic Republic of Iran, a conference on this topic will be held at xxx, in this coming winter [2008]. Your cooperation is highly appreciated. Please inform your faculty members and students about the conference, so that they will be able to send their abstracts.

A sum of 4,000,000 Rials [US\$400] and 15,000,000 Rials [US\$1500] will be provided for proposals that outline how to indigenize a particular department/faculty or a university, respectively.

Sincerely yours,

$\mathrm{Xxx}$

(Field notes, University \#3, Tehran, October 2007; author's translation) 
This letter was followed by a call for papers, which is presented below.

\section{Call for Papers \\ Conference on the Indigenization of the Field of Humanities in Iran}

The Islamic Republic of Iran feels obligated to indigenize the field of Humanities in the country. The field of Humanities should be indigenized in a sense that they meet the needs of the country, on the one hand, and be in accordance with Iranian-Islamic ideology, on the other hand. As such a conference will be held at xxx in winter 2008. If you are interested, please send your abstracts to $\mathrm{xxx}$ no later than 15 December 2007.

The following themes will be covered in the conference:

(1) Theoretical frameworks of indigenization.

(2) Issues and concerns about local adaptation.

(3) Learning from the experience of other countries.

(4) How to indigenize the sub-fields of humanities.

(5) The methodological aspects of indigenization.

(6) Case studies on local adaptations.

(Field notes, University \#3, Tehran, October 2007; author's translation)

Equal efforts have been made to promote Islamic ideology through various plans. One such plan was the enactment of 'A Comprehensive Plan for the Memorization of Koran and Understanding of Koranic Knowledge', executed by the Ministry of Culture and Islamic Guidance in early 2006. In an interview on 7 July 2008 with Iranian National Radio, Ayatollah Shahsavani, the director of the Koran project, stated that 3000 courses, of which 1000 were on memorization of the Koran and 2000 were on the translation of the Koran and Hadith, were offered by the Ministry of Culture and Islamic Guidance in summer 2007 just in Tehran; some 45,000 students took the courses and received certificates (Field notes, Iranian National Radio, 7 July 2008). Similarly, the Supreme Council of the Cultural Revolution Regulation No. 603 (1 May 2007) and No. 608 (9 July 2007) launched online religious programs in Persian for an Iranian audience and in Arabic and English for an international audience, to counter the allegedly 'false' information online. 


\section{Unfavorable Attitudes Towards the British Council}

The British Council, as was discussed in the preceding chapter, returned to Iran in 2001 after a hiatus of 23 years, at the request of the IRI's reformist administration under President Mohammad Khatami. From this point until mid-2006, the Council was able to re-establish itself, especially through close collaboration with local private English language institutes. With the rise of Mahmoud Ahmadinejad to the presidency, this 'cooperation' discourse was gradually replaced by a discourse of antagonism, which could be due in part to the United Kingdom's opposition to Iran's nuclear energy program (for more, see Borjian, 2011).

This change of attitude coincided with the appointment of Neville Bain as director of the British Council Iran in December 2006. Prior to his appointment, as was related by the local staff members of the British Council Iran, Neville Bain had spent a couple of months in Tehran, where he took Persian courses and made some arrangements for his stay. After his appointment, he went back to London to bring his family with him to Tehran, but he was refused a visa. The Iranian Ministry of Foreign Affairs notified the British Embassy in Tehran that British nationals were no longer welcome to work in the country, forcing Bain to operate from London or Dubai (Personal interview with staff member \#3 of the British Council Iran, Oolhak, Tehran, May 2008).

At the same time, the Ministry of Intelligence of the IRI accused the Council of conducting 'unauthorized' social, cultural and educational activities in the country; a committee was formed in Iran's parliament (majles) in May 2007 to investigate the matter further. The details of the accusation are provided in the following excerpt from the IRI's state-run English language newspaper, the Iran Daily:

Kazem Jalali, head of the Majlis National Security and Foreign Policy Commission, said on Tuesday that the cultural department of the British Embassy in Tehran has been undertaking extensive activities in cultural and social areas without permission from the Iranian government. He stressed that neither the Ministry of Culture and Islamic Guidance nor the Foreign Ministry has issued a permit for the British Council's cultural activities in Iran. He quoted Intelligence Minister, Gholamhossein Mohseni-Ejei, as saying that the center has been implementing cultural and social programmes since 2004 without any authorization. Jalali noted that the British Council teaches the English language, sends students and instructors abroad either for continuing 
education or attending conferences and trains journalists. (Iran Daily, 23 May 2007; quoted in China's People's Daily)

This accusation was soon followed by an official order from the Ministry of Intelligence, prohibiting all state-run organizations, ministries and universities from collaboration with the British Council. By July 2007, the website of the Council was blocked, and its IELTS exam center was shut down. The Council was not allowed to organize public events such as workshops and conferences. A kiosk was placed by the Ministry of Intelligence outside the Council's offices to monitor visitors and to prevent the entry of more than two people (Personal interview with staff member \#1 of the British Council Iran, Qolhak, Tehran, April 2008).

In response to these challenges, the Council embarked on a new strategy. In December 2007, Bain was replaced by M. Khajenouri, a graduate of Columbia University, as the new director of the Council - the first non-Briton appointed to the post since the inception of the Council in Iran in 1942. Khajenouri maintained the operations of the British Council Iran in several ways. Firstly, efforts were made to collaborate with the private sector in the country, albeit implicitly. The following excerpt illustrates an instance of such a collaboration.

Since early 2007, the British Council has not been officially permitted to work with state-run organizations in Iran. On the other hand, the Council has been able to secure the trust of the private sector for collaboration. In April 2008, with the support of a private Sport Center, we managed to organize a workshop on Sport and Nutrition. The workshop was funded by the Council and was run by three British experts. Yet, the experts were not invited by the Council but rather by the local Sport Center. The intermediary who cooperated with the Council, requested that the logo of the British Council should not be placed anywhere on the workshop site. The request was accepted by the Council, and thus, the workshop was held successfully. (Personal interview with staff member \#1 of the British Council Iran, Qolhak, Tehran, April 2008)

The Council also continued to offer its scholarships and awards to Iranian nationals. In 2007, 14 full scholarships, four partial scholarships and three awards were granted. Finally, the Council also worked with intermediaries to bring representatives of British universities to the IRI. Below is an announcement regarding a visit from the University of Manchester, copied from a flyer at the Council Representation in Tehran in April 2008. 


\section{The University of Manchester Visit}

Tehran May 2008

We are happy to announce that Mr. Mike Gibbons, Deputy Director, International Development at the University of Manchester is visiting Iran to hold a presentation on the study opportunities at this university, on the following date: Friday 9 May 2008.

The presentation will be held at xxxxx.

If you are interested in the University of Manchester and want to pursue a course of study at this University, then why not reserve a place by contacting xxxxxx.

(Bulletin board of the British Council Representation, Tehran, April 2008; emphases were in the original text)

The end of the British Council's operations in Iran came on 31 January 2009, when the Council was instructed to suspend all its activities and the local staff were laid off or, as the British say, were 'forced to resign' from their posts. ${ }^{1}$ The following note was posted on the website of the British Council Iran after the closure of its representation in Tehran:

With regret, we have had to suspend all our operations in Iran, effective 31 January 2009. Our hope is that we will be able to secure the agreement of the Iranian Authorities to allow us to resume as soon as possible education and cultural programmes between Iran and the United Kingdom for the benefit of the peoples of both countries. ${ }^{2}$

In the absence of a direct partnership, the British Council has turned to the social media to keep their relationship open with Iranians. 'Follow us on Facebook' is one such example. The Council's online operation covers many cultural and English language teaching and learning activities, including seminars, English classes and IELTS reading practice. The following excerpts are taken from the official website of the British Council Iran:

Although the British Council does not currently have an office open in Tehran, we are committed to keeping the cultural relations channels open.... You can find a wide variety of topics presented by experts from across the world here.

You can also apply to present at the British Council seminars yourself. Follow this link (www.teachingenglish.org.uk).... These seminars encourage debate on areas of contemporary interest in the field of English 
language teaching and learning. The series combines informal networking events with more formal workshops and presentations....

English Corner Online is a meeting place for people from all around the world who want to practise speaking English. Sign up, make friends and start speaking....

(http://www.facebook.com/britishcounciliran)

In March 2009 Saffar Harandi, the former Minister of Culture and Islamic Guidance and the current spokesman for the Office of the Prosecutor General announced that some five million local websites had been closed down due to their 'onslaught on ethics and religious identity' (Arjomand, 2009: 159). In January 2012 the state-run news agency, Fars, reported that, at the Digital Technology Exhibition held in Tehran, the icon of YouTube was stoned as a symbol of the 'Great Satan'. In September 2012, as reported by the Mehr New Agency, another state-run organization, Reza Taghipour, the Iranian Minister of Communications and Information Technology, announced that Iran's 'national internet' would operate nationwide by the end of the month, which can be presumed to be a strategy to prevent the locals from having access to the global internet (for more, see Omeedvar (2012) The Stoning of YouTube and Mehrdadm (2012) Launching the National Internet).

Hence, the question that remains is: To what extent can the British Council continue to extend its influence via its online programs in Iran - a nation in which the internet is highly safeguarded by the government for better or for worse?

\section{Unfavorable Attitudes Towards International Publishers}

In the previous chapter, we illustrated some instances of how foreign ELT books, purchased at the Tehran International Book Fair, found their way into classrooms in Iranian universities. In addition, the Book Fair was the only source of interaction between Iranians and representatives of foreign publishers. However, from May 2007 the structure of Tehran Book Fair witnessed a notable change, which is generally understood by opponents as another strategy of the state to minimize unwanted foreign influence.

The decision was made to move the exhibition from Tehran's International Exhibition Center to the mega-mosque known as Mosallä, still under construction. The official justification for this sudden change of location was the need to regulate the flow of traffic, which is, indeed, a major problem in Tehran. 
In addition, the Fair was split into two separate sides for local and international exhibitors. The registration fees, both for foreign publishers and visitors, were drastically increased (Mirzai, 2007; Whitlock, 2007).

This official justification for changing the location of the Tehran International Book Fair, i.e. regulating the flow of traffic, was met with some skepticism, judging by the comments of many local publishers, including the one below:

Just to give you an idea of how things work chaotically in Iran, I should say that, on the one hand, our state-run Friday Prayer Sermon (namāz-e jom'e), which no one attends, is held in Tehran University [the oldest and the most prestigious university in the nation], in which knowledge is supposed to be promoted. On the other hand, our international book fair is held in the country's Mosalla [the mega-mosque], in which religion is supposed to be promoted. The question as to why the locations of these two events are reversed would be interesting to explore ... But I am positive that it has nothing to do with so-called 'regulating the flow of traffic'! (Interview notes, Comments made by an Iranian publisher, May 2008)

When I visited the 21st Annual Tehran International Book Fair, held on 1-11 May 2008, I found that it was very different from those I had visited previously. The exhibition was divided into three separate parts: a section for books published by local publishers, in which the most prominent spaces were given to the religious books published by the state; a section for books published by publishers from the Muslim world, in which a disproportionately large space was allocated for Hezbollah and Hamas; and, finally, a section for books published by Western publishers, with just a few publishers attending, including the Taylor \& Francis Group, Routledge, Edward Elgar Publishing, Oxford, Longman and Cambridge University Press, along with a few others. No foreigners were present at the exhibition stands of foreign publishers, as local representatives were in charge of selling foreign books. Skimming through the titles of the ELT books, I noticed that almost all the books were quite old. I was told by a local representative of a British university press that, due to the unwelcoming policies of the government, foreign publishers had decided not to send their new books and that those exhibited were left over from previous years.

\section{Private Language Institutes: Unfavorable Policies and Responses}

Private English institutes were also subject to state policies that aimed to minimize international collaboration. A decree issued in early 2006 and 
forwarded to all local private language institutes explicitly prohibited collaboration with foreign educational establishments, unless such partnerships had been registered with and approved by the Ministry of Higher Education (Interview transcripts, Director of Work Permit Division, Ministry of Culture and Islamic Guidance, 17 February 2008).

The institutes responded in different ways to this government intervention. Some complied with the order, the most notable of which were perhaps the Kish and Shokuh Language Institutes. The former can be regarded as the first agent of the 'internationalization' of the field of English in Iran, responsible for the importation of communicative language teaching (CLT) together with the British English textbooks Headway and Interchange into the country back in the early 1990s. The latter was the first and oldest Iranian English language institute, established in Iran in 1950. Both institutions have the highest number of branches (around 300) throughout Iran. To comply with the state's top-down order, since early 2006 the Kish Language Institute has abandoned its partnership (established in 1999) with Cambridge University - a partnership that had permitted Kish to offer the Cambridge-driven English exams of KET, PET, CAE and CPE in Iran. Although today Kish still organizes courses on preparation for these exams, it no longer offers these exams locally (Interview transcripts, Director of Private School \#1, 18 December 2007). The Shokuh Language Institute also complied. When I visited its headquarters in Tehran in the winter of 2008, a large flier was posted on the wall, with the title 'Shokuh-Canada'. When I asked whether the institute was collaborating with any Canadian language centers, the reply was negative. A contract had been signed but the partnership had to be terminated following the government-issued decree (Interview transcripts, Director of Private Language School \#2, 18 April 2008).

Many other language institutes, however, continued to represent themselves as the legitimate representatives of foreign universities in Iran, a practice illustrated in the advertisement below and Figure 6.1.

HDP Educational Institute is the official representative of Avicenna College (Hungary) and Holborn College (London) in Iran. We provide general English courses and prepare students in biology, chemistry, physics and mathematics in English. We provide assistance in the visa and travel arrangements. Our expert consultants advise the applicants in finding the best location for their further studies.

(Excerpt from the website of HDP Language Institute, Tehran, October 2007) 


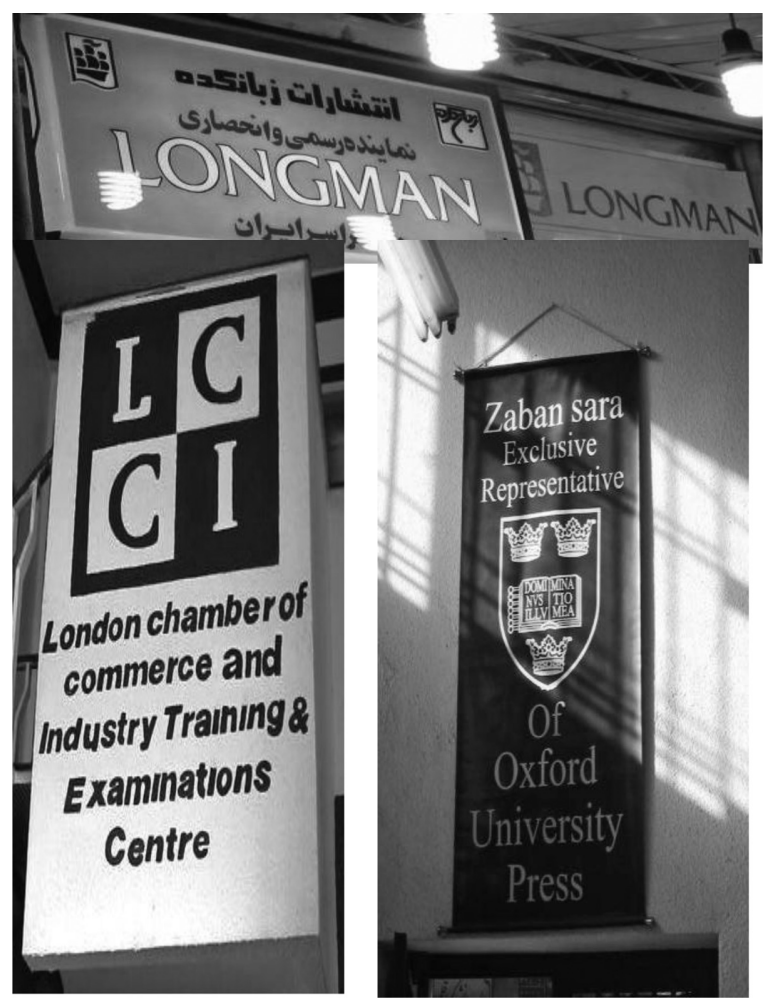

Figure 6.1 Instances of signs used by Iranian private language institutes to illustrate their collaboration with foreign educational establishments. (Field picture, Tehran, 2007-2008)

Another strategy developed by the private language institutes to resist, challenge or perhaps renegotiate the state's top-down isolation policies was to request that local publishers make more pirated foreign English books available locally. As discussed in the previous chapter, Ayatollah Khomeini issued a fatwa allowing the purchaser of a book to copy or reproduce it as his/ her property (Emami, 1993). Nonconformity to the Universal Copyright Convention (UCC) allowed the local press to pirate foreign textbooks with no penalty.

A 2007-2008 list of pirated textbooks published by a local publisher is provided in Table 6.1 just to illustrate the high rate of borrowing of ELT materials from abroad, most particularly from the United States and the United Kingdom over this timespan. 
Table 6.1 Books published/pirated by a local publisher (2007-2008)

\begin{tabular}{lrlr} 
Book themes & $\begin{array}{c}\text { No. of } \\
\text { books }\end{array}$ & Book themes & $\begin{array}{c}\text { No. of } \\
\text { books }\end{array}$ \\
\hline English, children's education & 152 & English, grammar & 59 \\
\hline English, adult education & 96 & Teaching English and linguistics & 54 \\
\hline English, listening & 16 & English, vocabulary & 36 \\
\hline English, conversation & 18 & English, comprehension & 20 \\
\hline English, illustrated dictionaries & 12 & English, IELTS & 42 \\
\hline English, dictionaries & 32 & English, TOEFL & 18 \\
\hline English, slang and idioms & 22 & French & 19 \\
\hline English, writing skills & 29 & German & 10 \\
\hline English, testing & 6 & Turkish and Russian & 8 \\
\hline English, reading & 44 & English stories & 480 \\
\hline
\end{tabular}

Total $\quad 1,173$

Source: Catalogue of X Publications (2007-2008)

The data presented in Table 6.1 reveal several facts about the politics of English teaching and learning in Iran. Firstly, contrary to the isolation strategy of the country's politicians, there seems to be a high demand for learning about the culture of English-speaking nations in Iran. Out of 1173 books pirated by the above publisher just in 2007-2008, 480 were English fiction, 59 American and the rest British. The majority of these narratives were about Western icons like Leonardo DiCaprio, Michael Jordan, Tom Cruise, Julia Roberts, Bill Gates, Princess Diana and Mr Bean, etc. Secondly, British books became the primary source of emulation for Iranian publishers. On the subject of fiction alone the number of British books ran to 427, as against 53 American titles. Thirdly, although English has continued to be absent from primary school curricula, there has been a high demand for English books at pre-school and primary school levels - 152 titles - which suggests that parents realize the importance of English for their children. Fourthly, the data also reveal a high demand for academic books, most particularly in the fields of TEFL and applied linguistics - 54 titles. Fifthly, the data illustrate indirectly the country's high rate of brain drain, judging by the 42 pirated titles on the IELTS, an exam required for emigration to countries like Canada and Australia. According to a report by the International Monetary Fund, Iran ranks highly in brain drain among developing countries, with an annual estimate of 150,000 emigrants (200,000 according to the Islamic Republic's official statistics) (Harrison, 2007). 
The influx of foreign textbooks into the country has been too high to be controllable by the Ministry of Culture and Islamic Guidance, in charge of purifying all books from so-called 'unwanted' foreign cultural elements and appropriating them along the lines of government ideology. As a result, foreign English textbooks continued to enter the local market without being 'appropriated' content- or picture-wise, just as they did in the preceding phase of reform in Iran (1997-2005).

\section{Subtle Opposition at Universities}

While the state was concerned about implementing policies to prevent 'unwanted' foreign influences, a subtle opposition towards the state's top-down policies began to take shape at universities. This was evident, for instance, in the content of university newsletters, newspapers and magazines.

In its April 2008 issue, the English newsletter of the Islamic Azad University, known as Infinity, published a front-page article entitled 'Globalization and higher education', criticizing state monopoly of higher education. It is interesting to note that no explicit reference was made to the local government. Rather, a discussion of Japan's successful decentralization of its higher education approach was used as a springboard to voice subtle objections:

[E]ach government gets the university leadership it deserves, more traditional and bureaucratic or more innovative and lucrative. The more governments limit university autonomy and take over management and administrative tasks, the less freedom of action for the university leadership will be. ... Recent experience in Japan, where public universities have been taken out of the state system ... illustrated clearly that then the traditional internal structures come under pressure, and an intention to adapt develops.... When an individual university must look at the world around it and learn how to survive a complete change in thinking takes place, which leads to changes in finances, structure, and modes of operation. (Infinity, April 2008: 2) $)^{3}$

Similarly Farhikhtegān, the official trilingual (English, Arabic and Persian) newspaper of the Islamic Azad University, devoted its 27 May 2008 edition to the issues and concerns raised at the National Conference on Higher Education and its Contribution to Innovation and Development. The conference was held at the Science and Research Center of the Islamic Azad University in Tehran in May 2008. In particular, Dr Mojtabai, a distinguished professor of Persian literature, drew attention to the failure of Iran's 
education system to produce a labor force with the required levels of proficiency in English. Calling English 'the main language of global research and as the prerequisite for innovation and development', Mojtabai urged the country's politicians either to upgrade the English curriculum or to add more English courses as extracurricular activities.

A similar concern was raised in Simā-ye Khärazmi, the newsletter of the Teacher Training University (Tarbiat-e Moallem). An article entitled 'Thirteen characteristics of a literate individual' (Ahmadi, 2007) made reference among other traits to 'fluency in English', 'ability to use computer and information technology' and the ability to 'adapt oneself with innovation and modernity'. The author concluded that a change in a nation's attitudes and perception towards 'innovation and modernity' is a prerequisite to achieving the scientific growth needed for economic growth, something considered to be lacking in Iran.

University professors were not alone in voicing their concern about English. Students also began to express their enormous desire for learning the English language. They wished to extend their knowledge of the language from grammar to the sociocultural aspects. This tendency is exemplified in the following excerpt, taken from the student English magazine of a university in which I conducted fieldwork.

The Mind Raider

November 2007 Issue

A Word from the Editor:

Noticing that there were no English magazines or newsletters whatsoever being published in the school, we thought that should change. By starting The Mind Raider magazine, we wish to address English and nonEnglish students interested in reading such materials. This is a magazine for us and by us.

Grammatical rules and vocabulary alone isn't enough to learn and study a language thoroughly; it is the history and culture of the people which form a language. Thus, our main concern is to introduce readers to the bits and pieces which have indirectly inspired the English language and its literature.

$\mathrm{Xxx}$

Editor-in-Chief, The Mind Raider

(The Mind Raider, Student English magazine, University \#3, November 2007)

The same desire to learn about the culture of English-speaking people can be seen in the first issue of the magazine, whose table of contents includes many 
topics related to cultural aspects of life in the United States - 'Plagiarism: a summary of a Northwestern University article', 'Edgar Allen Poe: a biography', 'Mount Rushmore National Memorial' and 'Yale University', among many others.

\section{English Departments and ELT Materials}

Private language institutes are not the only consumers of imported ELT materials in Iran. A similar trend can be observed within the TEFL departments of the country's higher educational institutes. A good illustration is the list of recommended books for MA majors in TEFL in the country's national university entrance exam. As illustrated below, out of 14 recommended books for the entrance exam of 2008, only one book was homegrown and the rest were pirated foreign books.

\section{MA in TEFL: List of Recommended Books for University Entrance Exam, 2008}

Brown, H.D. (2000) Principles of Language Teaching and Learning. New Jersey: Prentice Hall.

Brown, H.D. (2001) Teaching by Principles: An Interactive Approach to Language Pedagogy. New York: Addison Wesley.

Chastain, K. (1998) Developing Second Language Skills. New York: Harcourt Brace Jovanovich.

Farhady, H., Jafarpoor, A. and Birjandi, P. (1994) Language Skills Testing: From Theory to Practice. Tehran: SAMT.*

Fromkin, V. and Rodman, R. (1988) An Introduction to Language. New York: Holt, Rinehart and Winston.

Heaton, B. (1991) Writing English Language Tests. London: Longman.

Krashen, S. (1988) Second Language Acquisition and Second Language Learning. California: University of Southern California Press.

Larsen-Freeman, D. (1986) Techniques and Principles in Language Teaching. Oxford: Oxford University Press.

Madson, H. (1983) Techniques in Testing. Oxford University Press.

McNamara, T. (2000) Language Testing. Oxford: Oxford University Press.

Richard, J. and Rodgers, T. (2001) Approaches and Methods in Language Teaching. Cambridge: Cambridge Language Teaching Library.

Rivers, W. (1981) Teaching Foreign Language Skills. Chicago: University of Chicago Press.

Wallwork, J.F. (1996) Language and Linguistics: An Introduction to the Study of Language. Cambridge: Cambridge University Press. 
Yule, G. (1988) The Study of Language. New York: Cambridge University Press.

*Homegrown.

(Field notes, Universities \#1 and 3, November 2007)

This result is confirmed by the data retrieved from an electronic survey undertaken as part of this study and completed by 88 Iranian professors of English which shows a high rate of borrowing of ELT materials from abroad on the part of TEFL departments throughout the country. In response to the question, Are most of your class reading materials homegrown or foreign-produced?, 83\% reported that they had been using only foreign-produced materials, compared to $17 \%$ who reported the use of both homegrown and foreign-produced materials. A closer look at the data reveals that, among the foreign ELT scholars whose research has made the greatest contribution to the country's TEFL course syllabi, the following names stood out: Jack Richards (25.8\%), Rod Ellis (24.2\%), David Nunan (22.7\%), Henry Widdonson (15.2\%) and Douglas Brown (12.1\%).

The contribution of research conducted by Iranian scholars is considerably lower. In response to the question, Does the research conducted by Iranian scholars make a substantial contribution to your class syllabi?, 77.3\% reported 'No', $19.3 \%$ reported 'Yes but not much', and only 3.4\% reported 'Yes'. A closer look at the data reveals that $56.1 \%$ of those who reported using locally produced ELT materials in their classes named Language Skills Testing: From Theory to Practice (Farhady et al., 1994), i.e. the only locally produced textbook included in the list of recommended books for MA majors in TEFL in the country's national university entrance exam, as illustrated above. The names of other local scholars that stood out were: Birjandi, Dabir Moghaddam, Jafarpour, Keshavarz, Miremadi, Riazi, Yarmohammadi and Ziahosseiny.

e-Journals have also made a contribution. In response to the question, What are the first top four ELT journals that make the most contribution to your class syllabi?, the following four ELT journals ranked highest: TESOL Quarterly (39.4\%), Journal of Applied Linguistics (23.9\%), ELT Journal (21.1\%) and Language Teaching Journal (15.5\%), respectively.

But what are the stimuli for this large-scale borrowing of ELT materials from abroad, most particularly from English-speaking nations, on the part of Iranian TEFL departments?

\section{Low Research Output}

It is true that over the past three decades Iran has enjoyed considerable expansion in various fields of higher education, including English. The 
number of universities, faculty members and graduate students has increased. Despite this expansion, the research output of Iranian universities remains very low. Malekzadeh et al. (2007), for instance, document the number of articles contributed by Iranian scholars to international journals from 1993 to 1998: in 1993, 299 articles by Iranian scientists were cited in SCI (Science Citation Index). This figure rose to 368 in 1994, 463 in 1995, 528 in 1996, 667 in 1997 and 1023 in 1998. A closer look at the data reveals that almost 95\% of the articles belonged to natural sciences; citations in the arts, humanities and social sciences comprised less than $5 \%$ of the indexed output. Azizi (2006: x) reports that, while there was a total of 1934 articles by Iranian scientists in SCI journals in 2002, there were only 69 articles in SSCI (Social Science Citation Index) journals, and six articles in AHSCI (Arts and Humanities Citation Index) journals. Considering the large number of faculty and graduate students in the latter two fields, then, such a low research output deserves notice.

Responses to the electronic survey also confirm the low research contribution of Iranian scholars to international ELT journals. Out of 88 respondents, only 20 reported that they had published or planned to publish abroad and of these, $25 \%$ reported that their articles were either 'in press' or 'in progress'. A closer look at the data reveals that more than half of the journals reported were Asian: Indian Journal of Applied Linguistics (20\%), Asian TEFL (India, 15\%), English Foreign Language Teaching Journal (Singapore, 10\%), and Translation Journal (Turkey, 5\%). Only one person reported that he/she had published a book review in the peer-reviewed journal, Language and Society (USA) (see Table 6.2).

Respondents were well aware that Iranian scholars lagged behind; 52 out of 88 blamed the low quality of indigenous research as the main factor for

Table 6.2 Iranian scholars' contribution to international ELT journals (2003-2008)

Journal Country/region No. of articles \%

\begin{tabular}{lllr}
\hline Indian Journal of Applied Linguistics & India & 4 & 20 \\
\hline Asian TEFL & Far east Asia & 3 & 15 \\
\hline E-FLT & Singapore & 2 & 10 \\
\hline Language and Society & USA & 1 & 5 \\
\hline Translation Studies in the New Millennium & Turkey & 1 & 5 \\
\hline Online journals (Reading Matrix, TESL) & - & 3 & 15 \\
\hline EUpal & Europe & 1 & 5 \\
\hline In press/in progress & - & 5 & 25 \\
\hline Total & & $\mathbf{2 0}$ & $\mathbf{1 0 0}$
\end{tabular}

Source: Electronic survey, winter 2008 
borrowing their class reading materials from abroad. The following comments from a TEFL professor offer an example of this thinking.

I'm not really happy with the power relation [sic] we have with countries in the Center [English-speaking nations] and I don't think they have much contribution to make to our situation here. But unfortunately because of the low quality of our research and the fact that we are not producing, they have the space and voice to say whatever they want to. But we don't have such space. This is not to suggest that we are not given the space but rather we have never asked for the space to be given. (Interview transcripts, TEFL professor, University \#2, 7 November 2007)

Several factors account for the low research output of Iranian universities. The first factor is the low ratio of expenditure on research and development (R\&D) in the national budget. The phrase 'research and development' is defined by the Organization for Economic Co-operation and Development (OECD) as "creative work undertaken on a systematic basis in order to increase the stock of knowledge, including knowledge of man, culture and society, and the use of this stock of knowledge to devise new applications' (OECD Factbook, 2008). R\&D expenditure, i.e. the ratio of gross domestic expenditure on $\mathrm{R} \& \mathrm{D}$ to gross domestic product (GDP) has classically been considered an indicator of scientific progress and knowledge production in the developed world. However, as the insights of Alaghband-Rad and his coauthors (2005) warn us, experience from the former Soviet Union, Eastern Europe and many Third World countries has shown that this indicator should be regarded with caution, as many research institutes and organizations in the above-mentioned countries did in fact make use of funds without creating knowledge.

Figure 6.2 illustrates $R \& D$ as a percentage of GDP for OECD countries in 2006. For OECD countries as a whole, average $R \& D$ spending as a percentage of GDP was $2.25 \%$. Sweden has the highest ratio at $3.82 \%$, followed by Finland (3.45\%) and Japan (3.33\%). The Slovak Republic had the lowest ratio at $0.49 \%$. Other OECD countries with low R\&D spending as a percentage of GDP were Greece (0.5\%), Mexico (0.5\%) and Poland (0.56\%).

The ratio of $\mathrm{R} \& \mathrm{D}$ expenditure to GDP in Iran has fluctuated from $0.2 \%$ to $0.4 \%$ over the past two decades, far below that in the OECD countries that appear in Figure 6.2. According to Malekzadeh et al. (2007), before 1996 there was no clear estimate of R\&D expenditure in the country's GDP. Research expenditures were stipulated as 'research and investigation' and were dispersed among the allocated funds and other resources available to ministries and other state-run organizations and foundations. It was only 


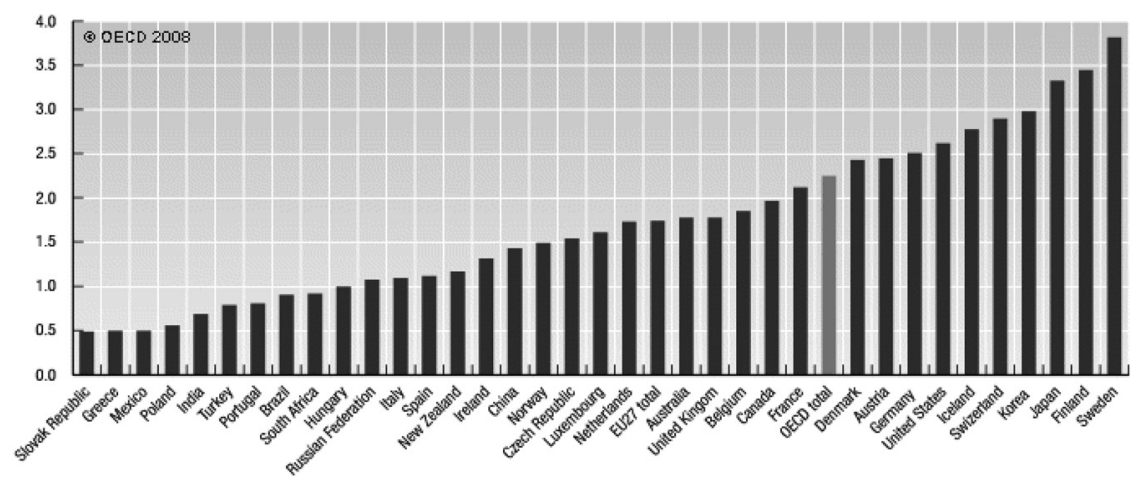

Figure 6.2 Gross domestic expenditure on R\&D as a percentage of GDP, 2006 Source: OECD Factbook (2008).

after this point that a specific allocation known as the Research Chapter was incorporated into the country's national budget. Prior to 1996 only $0.47 \%$ of the national budget was allocated to $\mathrm{R} \& \mathrm{D}$. This proportion rose slightly to 0.59\% in 1997 and fell again to 0.42\% in 1998 (Malekzadeh et al., 2007: 2). The Third Development Plan (2000-2004) set the goal of increasing the ratio from $0.4 \%$ in 1999 to $1 \%$ in 2003 (Article No. 102, Section B, Laws of the Third Development Plan 2000-2004). However, this policy goal has hardly materialized at the policy action level. Today, Iran still spends an average of $0.4 \%$ on R\&D (Board of Supervision and Assessment of Cultural and Scientific Affairs, 2005-2006). It ranks far behind industrialized societies and the OECD average of $2.25 \%$.

In order to encourage Iranian scholars to publish and contribute nationally and internationally, the Iranian government emphasized 'research production' and publication became a prerequisite for academic ranking. 'Publish or perish' became the norm. This strategy, however, can be seen as counterproductive.

Publication is not valued in Iran. It is an end to waste the means. The quality and area is of no importance. What is important is a higher academic position, for which publication is needed. (Electronic survey, TEFL professor, winter 2008)

The long working hours of Iranian professors are another factor contributing to their low research output. An average full-time professor, for example, has to be present for 40 hours weekly, of which 18 hours are devoted to actual teaching. Fifty-seven out of 88 professors (64.8\%) who participated in 
the electronic survey of the present study, complained about their long working hours.

The main problem in Iran is that professors teach so many hours at several universities and institutes to earn a decent living. We don't have time to conduct research. (Electronic survey, TEFL professor, winter 2008)

Another driving force behind the low research contribution of Iranian professors is a lack of research facilities and resources. Many universities lack basic research resources and technological tools, such as access to e-journals, books etc. The situation worsens as one travels further from Tehran. In response to the question, How would you rate the research resources in your university?, 53.4\% said 'poor' and 33\% 'average'. Only 11\% rated their research facilities as 'above average' and $1.1 \%$ as 'excellent' (Table 6.3). It should be noted that the majority of those who rated the research facilities of their universities as 'above average or excellent' were from the Instructors' Training University (Tarbiyat-e Modarres), the university that was established after the foundation of the Islamic Republic with responsibility for the training of the so-called 'pious' professors.

The limited opportunity for professional networking with the outside world also contributes to the poor research output. Only 27.3\% of respondents reported that they had been members of an international ELT association (Table 6.4) and $36.4 \%$ said that they had presented a research paper at a foreign ELT conference (mostly in Asian countries) (Table 6.5).

Table 6.3 Quality of research facilities in Iranian universities

University's research facilities Frequency $\quad \%$

\begin{tabular}{lrr}
\hline Poor & 47 & 53.4 \\
\hline Average & 29 & 33.0 \\
\hline Above average & 10 & 11.4 \\
\hline Excellent & 1 & 1.1 \\
\hline Total & $\mathbf{8 8}$ & $\mathbf{1 0 0}$
\end{tabular}

Table 6.4 Professional networking among Iranian ELT professors

\begin{tabular}{llrr} 
Are you a member of any international TEFL association? & Frequency & $\%$ \\
\hline Yes & 24 & 27.3 \\
\hline No & 64 & 72.7 \\
\hline Total & 88 & 100
\end{tabular}


Table 6.5 TEFL professors and their proportion of international presentations

Have you ever presented your paper in Frequency

$\%$ an international TEFL conference?

\begin{tabular}{llc}
\hline Yes & 32 & 36.4 \\
\hline No & 56 & 63.6 \\
\hline Total & $\mathbf{8 8}$ & $\mathbf{1 0 0}$
\end{tabular}

A response from a TEFL professor to my question as to Why do Iranian professors not produce much? serves as a useful summary of these various factors. He said:

There are a lot of different factors involved here. (1) It depends on where you work. If you are working in a world-class university, so you have a lot of connections and networking. So that networking might help you or facilitate becoming an international figure. But if you work in a university, which is not a world-class university, like the one in which I teach then, the networking is absent and if it exists, it is a primitive type of networking that would limit you. (2) One of our main problems is our long teaching hours. Well, the teaching hours depends on each professor's rank; an assistant professor should teach 12 hours per week whereas an associate professor should teach 10 hours per week, and a professor should teach 8 hours. But these are just on paper. In reality we teach 18 hours per week which is too much. But teaching is only one part of our work. We should work for a total of 40 hours per week. And then, there is no time for research. (3) Another issue is that there must be a link between the courses you teach and your area of interests/specialization. But such things do not exist in Iran. Among the courses I teach there might be only 1 or 2 that I like to teach and/or are related to my area of interest, but the rest is not. So if teaching is not research-based, then its research contribution is low.... (Interview transcript, TEFL professor, University \#1, 18 September 2007)

In summary, if progress is to be made, adequate funding, proper research facilities and improved academic infrastructure will be required. Collaboration with international research centers can also improve the quality of research, as can balancing teaching and research.

\section{State Ambivalence Towards English}

The data obtained from various sources, presented above, confirm the fact that the Iranian authorities of post-2005 have used every opportunity to 
reduce foreign influence in the country's education system as a whole and in English education in particular. Nonetheless, the same politicians do not display hostility towards the English language per se. Rather, they have embraced English more strongly than their predecessors.

A good illustration of this tendency is Regulation No. 619 (6 November 2007 ) issued by the Supreme Council of the Cultural Revolution which amended previous government decrees to expand the role of English in education, permitting English to move from a subject of instruction to the medium of instruction in selected universities, including the University of Insurance (Dāneshgāh-e Eko-Bime), a branch of Allāmeh Tabātabāi University in Tehran. This regulation could even be described as anti-constitutional, since Persian has been the official and the only language of instruction since the 1980s (Article 15, IRI Constitution).

In order to minimize controversy, a new discourse was required in which English was no longer 'the language of the enemy', or the means by which the colonial-imperial powers subjugated Muslim nations and peoples. Nor was it a medium for the cultural invasion of the West. Rather, English was de-territorialized. It no longer belonged to the English-speaking nations but was rather a 'de-territorialized' 'world language'; its mastery would lead the nation to self-reliance and economic growth and the nation's citizens to membership of various global communities, scientific and scholarly ones in particular. Since late 2007, the clergy have been appearing on state-run television to stress the importance of learning English for the nation. One such figure equated the mastery of English with an Islamic Jihad - the duty of every Iranian to learn this language to facilitate the nation's self-reliance (Field notes, Iranian National TV, December 2007-May 2008).

The construction of the new discourse of 'English as the language of the world community' laid the ground for change in higher education. For the first time in the history of the IRI, international English exams such as TOEFL and IELTs became a prerequisite for university entrance at the doctoral level in the fields of math, science, medicine and engineering. Moreover, access to more English e-journals was provided to local universities to help the faculty and students stay abreast of developments in their fields. Some departments have even established weekly 'journal clubs' for their graduate students. In addition, the pressure on professors and doctoral students to publish English articles in international journals has been increased as a condition for promotion.

However, higher education is not the only place where English has renegotiated its role. Since late 2007, for example, Channel 7 has been broadcasting an English teaching program called Dialogue, for one hour twice a day, where the focus is not on 'indigenized', 'localized' or 'homegrown' English, but on standard American and British English. 


\section{Conclusion}

This chapter provides a detailed account of the social, political and educational context of Iran during the presidency of Mahmoud Ahmadinejad, whose domestic and foreign policies were shaped around the slogans of 'revitalizing the early revolutionary principles' and fighting 'the unjust imperialism'.

The data obtained from various sources presented above confirm a conflict between the interests of state and some non-state actors on various matters, including the borrowing and lending of foreign ideas in education in general, and English education in particular. Evidence of the negative views of the government towards the outside world can be found in the closure of the British Council, unwelcoming attitudes towards international publishers and the prohibition of the private sector from collaboration with foreign ELT centers. It is safe to conclude, too, that post-2005 Iranian politicians were even more in favor, at least at the policy discourse level, of the 'indigenization', 'Islamization' and 'purification' of the nation's education - the main pillars of the IRI's Cultural Revolution of the early 1980s - than their counterparts in the two preceding phases of reconstruction and reform. Such a tendency is exemplified by state-funded mass seminars and conferences on 'localizedindigenized knowledge' and the 'early retirement campaign' through which many 'unfit' professors were purged. It would, however, be misleading to assume that post-2005 politicians were against English. It was during this phase that IRI policy documents made English the medium rather than a subject of instruction in selected universities, a policy that has not fully materialized at the practice level. It was during this phase, too, that high scores in international English exams became a prerequisite for university entrance in various fields at graduate level and access to e-journals reduced the sense of isolation felt in many Iranian universities. Last but not least, it was during this phase that state TV began to broadcast programs aimed at teaching American and British standard English.

However, some questions remain: What were the causes of this fundamental change of attitude on the part of the most conservative IRI politicians towards English? Was it the result of subtle opposition at a subnational level, voiced by a coherent collective body of actors such as professors, private English language institutes, private publishers and students? Or was it the result of immense pressure by transnational organizations, the World Bank and the IMF, in particular, on Iranian politicians, demanding further structural adjustment and privatization as a condition for loans? Or was the change of attitude symptomatic of the determination of IRI politicians to turn the cultural capital of English knowledge and skills into economic 
capital for the nation? All of these factors have no doubt contributed to the new discourse. The field of English language teaching and learning could thus be seen as a site of struggle in Iran where multiple forces compete forces interacting above, below and at the nation-state level, forces that exert influence upon one another, and sometimes find themselves in direct or indirect dialogue.

\section{Notes}

(1) For the British side of the story about the closure of the British Council and the intimidation of local staff to force them to resign by the local government, see: BBC News at http://news.bbc.co.uk/2/hi/middle_east/7870503.stm; http://news.bbc. co.uk/2/hi/middle_east/7872525.stm; see also Channel 4 News at http://www. channel4.com/news/articles/politics/international_politics/tehran + british + council + closed + +iran + says + they + had + no + right + /2924957.

(2) Website of the British Council Iran at http://www.britishcouncil.org/iran.htm, accessed 20 May 2010.

(3) In July 2008 I was informed by the editorial board of Infinity newsletter that the director of the newsletter, who also served as the Vice President of International Affairs at the Islamic Azad University, had been fired from both posts. It would be interesting to explore the question as to whether the director's receptiveness towards foreign influences was the cause of such a dismissal. 


\section{Forces From Above, Forces From Below}

Good people are good because they've come to wisdom through failure. We get very little wisdom through success, you know.

William Saroyan

\section{Introduction}

We began this book by shedding light on the ideological and political situation in Iran at the dawn of the 1979 Revolution, which replaced the country's two- millennium-old monarchy with an Islamic theocracy. At the time, the country's ideopolitical horizon was dominated by third-worldism, antiimperialism and anti-Western sentiments. Driven by the uncontested power of religion and bent upon an Islamic state, the country's new leaders were no longer interested in implementing the Westernized version of modernity and development. The goal was rather to craft a homegrown model free from the influence of the West (free-market economy) and the East (socialism) - a model based entirely upon Islamic ideology, not only in the economic and political spheres but also in the cultural and educational arenas.

Such a position also influenced the field of English education. The goal was to create an indigenized model of English education, free from the influence of the English-speaking nations. This aspiration became the policy goal which has dominated the political discourse of the Islamic Republic for a good part of the past three decades. Yet English education in Iran today is not entirely indigenized. Rather, it is marked by two forms of English: one, indigenized and the other, Anglo-Americanized.

We have argued that the internationalization of the field of English education in post-revolutionary Iran cannot be explained by relying only upon right-wing theories, using a normative yardstick to attribute this 
internationalization to the will and desire of the local borrowers who, in their quest for modernity and development, have enthusiastically borrowed Anglo-American English models from abroad. Nor can it be explained by drawing merely upon left-wing theories, such as that of 'linguistic imperialism', blaming exogenous forces or foreign lenders for lending or exporting their practices and models to post-revolutionary Iran. Likewise, it cannot be entirely explained by drawing upon agency-oriented theories like that of 'linguistic hybridity' to assign absolute agency to subnational forces. Instead, we have argued that these approaches are complementary rather than antagonistic or mutually exclusive, as each sheds light on one aspect or side of the complex process of educational borrowing and lending.

Using educational transfer as our main unit of analysis and drawing upon many insights from various academic fields, we proposed a new framework to examine the process, causes and agents of the two diverging trends of indigenization and internationalization within English education in Iran. Our central argument was the fact that educational transfer is a complex process, which involves 'two sides' (borrowing and lending), various forces with competing interests and motives at the 'three levels' (national, subnational and supranational), and 'multiple causes' (social, political, economic, educational, ideological, etc.). Using the case of English in Iran as a concept, we then focused on all these variables to unravel the politics of English language teaching and learning in Iran over the past 30 years.

\section{Forces From Above}

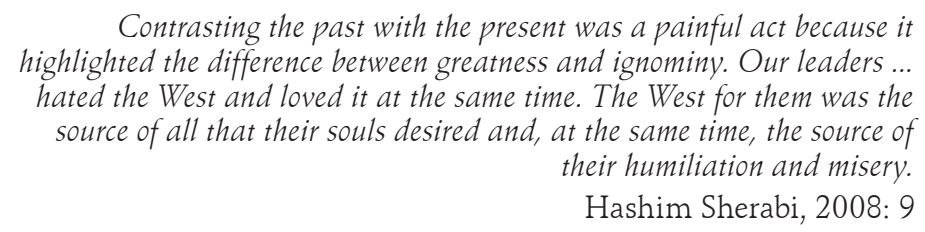

To what extent and in what ways has the state contributed to the 'indigenization' or 'internationalization' of the field of English education in post-revolutionary Iran and what have been the catalysts for receptiveness or hostility towards foreign ideas on the part of the state actors? Who have been the 'reference societies' for the local government and what roles have supranational forces played in the internationalization of English in post-revolutionary Iran? Has the state's dream of breaking away from the West and the capitalist world order materialized? Has the aspiration for the indigenization and localization of knowledge and the creation of an 
Islamic economic, social, cultural and, above all, educational world order been achieved?

For IRI leaders, the West has remained simultaneously a source of admiration and humiliation: admired for its scientific, economic, military, industrial and technological might; despised because its rise coincided with a weakening of the Islamic civilization that had once produced world-class scholars, scientists, mathematicians, philosophers and artists (Mehran, 2003). And this ambivalence has influenced all the policies embarked upon by the state since its foundation.

The humiliation towards the West has been manifested in the discourse of 'indigenization' - the grand narrative of belonging to a larger whole, the Islamic Umma, and looking to the glorious past of Islam to draw new policy lessons. But the grand narrative of indigenization was revisited as Iran entered the war with Iraq (1980-1988). The enemy, a core part of the Umma, received the backing of most Arab nations, pushing the leaders of the revolution to focus on national particularity. But nationalism in the motherland, Erān Shahr, was tightly linked to the notion of blood lines and the 'legitimacy' of the king (the Shah), something that the newly arrived politicians could not or did not want to claim. Linking their lineage instead to the twelve Shiite Imams, the state discourse now emphasized the Shiite faith and its marginalization within the melting pot of the Islamic Umma. This discourse has served as the basis of the 'indigenization' thesis and has been used against both internal and external 'enemies' (doshmanān-e däkheli va khāreji) throughout the life of the IRI.

In both the Revolutionary Phase under the rule of Ayatollah Khomeini (1979-1988) and the period of Returning to Revolutionary Roots under the presidency of Mahmoud Ahmadinejad (2005-present), political and ideological motives were the main impetus for 'indigenization' sentiments. In the former phase, indigenization was used as a springboard to denounce the legitimacy of the previous regime (the Pahlavi dynasty), claim legitimacy for the newly established regime (the Islamic Republic), suppress internal rebellions (mass opposition from all political groups and factions), and external aggression (war with Iraq and the West). In the latter phase, it was used to discredit the previous administrations of the Islamic Republic (the pragmatists and reformists) and external aggression against the nuclear energy program. Such hostile attitudes towards foreign influences impacted on English education. In both phases, the government made strenuous efforts to eliminate any external influence that would lead to dialogue between the natives and non-natives. While this policy was successful in the former phase (1979-1988), it has proved unachievable in the latter (2005-present) - in part due to the fact that globalization and information technology have 
reduced the deep isolation felt at home. The digital revolution since 1999 has reduced the absolute control of information and opened a new window of opportunity for ordinary Iranians to look abroad for lessons.

The Iranian authorities of the post-revolution have displayed different degrees of 'receptiveness' towards foreign influence over time - a gradual shift from 'implicit' to 'explicit' externalization. We have defined the former as a borrowing process in which no explicit reference is made to the source country or the lending institution, and the latter as a process in which the origins of the lessons are not hidden. With the exception of the reform phase (1997-2005) during the administration of President Khatami, 'implicit' externalization was the norm: Western countries were selected for the higher education of Iranian students; there was collaboration with the World Bank (during the second phase, or the Period of Reconstruction and Privatization, 1989-1997), and partnership with the World Bank and the UN (in both the third and fourth phases of the IRI). Instances of 'explicit' externalization include the partnership with the British Council (2001-2006) and international publishers, as exemplified by the Tehran Annual International Book Fair from 1987 onwards. Thus, contrary to what is often presumed, the influence of supranational forces has never been eliminated in post-revolutionary Iran. In fact, the West has remained the main 'reference society' for policy emulation, regardless of the profound anti-Western sentiments of the country's politicians.

Various reasons behind such receptiveness towards foreign lessons can be identified. First, it is possible to point to the covert admiration for the West alluded to above. Economic motives were another major factor for externalization, pushing politicians to look abroad for a promising model to address the country's ailing condition. As we have seen, the policies of privatization, decentralization and the knowledge-based economy originated not in Iran, where they were kept quiet under IRI development plans, but rather in the West. Political motives were also paramount. We have argued that, when current policies are contested, politicians turn to external references and international standards to legitimize the need for reform. Other factors include negative internal and external evaluations of the situation which pushed the authorities to draw lessons from abroad.

The impact of government receptiveness towards foreign ideas was particularly notable in English education. Policies borrowed either directly or indirectly reinforced ELT-related educational transfer. An instance of indirect reinforcement would be the importation of the World Bank's privatization policy and the UN's policy of the knowledge-driven economy. While the former led to the participation of the private sector in English education, the latter brought greater access to information technology, including the internet, 
e-books and e-journals. An instance of direct reinforcement would be the resumption of the relationship with the British Council in 2001.

It would be misleading, however, to assume that the state has played no role in the internationalization of English education in post-revolutionary Iran. Nor would it be accurate to overlook the role of supranational forces which drive the global market economy, politics and information technology. As we have illustrated throughout this book, both sets of forces have played a major role in the internationalization, and to a certain degree the Anglo-Americanization, of the field of English in post-revolutionary Iran.

\section{Forces From Below}

It was accordingly a silent challenge to the older, more powerful man who had the ability to slap and shoot, but was unable to compel the one slapped to bow to him or unclench his hands behind his back.

Hanna Mina, 2004: 124

To what extent and in what ways have Iranian subnational forces contributed to the 'indigenization' or the 'internationalization' of the field of English education in post-revolutionary Iran? And what were the catalysts for receptiveness or hostility towards foreign influence? Has the dream of 'homegrown' English education been realized?

Like the state, Iranian subnational forces have displayed different attitudes towards foreign innovations. In the early years of the revolution, those perceived as 'unfit' and/or the 'agents' of Westernization were eliminated, expelled from their posts or left the country in thousands. And those who stayed and kept their posts were either extremely loyal to the cause of the revolution or simply expressed no interest in foreign ideas for fear of the consequences. Private educational establishments were shut down, together with all their foreign-run counterparts. Elite networks were dismantled. A new wave of a pious but not necessarily skilled labor force entered universities to ensure the continuity of revolutionary principles. In the absence of supranational and an 'autonomous' set of subnational forces, the government took sole responsibility for education and its sub-field of English - the main character of the nation's education. However, this situation gradually changed.

The first initiatives came from the private sector and, notably, the private English language institutes. The movement began in the second phase of the Period of Reconstruction and Privatization (1989-1997), under the presidency of Ali-Akbar Hashemi Rafsanjani, whose outlook was more developmental than ideological. During this phase the state requested financial 
assistance from transnational organizations, and the World Bank's policy of decentralization and privatization was adopted as a means to improve the country's war-ravaged economy and the ailing education system.

An unintended outcome of privatization was a challenge to the virtual state monopoly of education. Private language institutes and publishers looked abroad for promising ELT textbooks to pirate - as Iran has never honored the international copyright convention - and new ELT methodologies including CLT and student-centered instruction were introduced. The success of the private sector was fuelled by the desires of students and parents. During the third phase (1979-2005), the Period of Global Outlook and Reform, under the presidency of Mohammad Khatami, professional or elite networks (university-based ELT units) also drove internationalization forward. So, too, did the advance of communication technology, and access to computers, the internet, e-journals and e-books.

The subnational forces have had their own motives for borrowing foreigndriven ELT standards and packages. ELT professional networks, conscious of the poor quality of locally produced English textbooks and the low research output in universities, wanted to be kept informed about new developments in their field. As already mentioned, the enthusiasm of Iranian students and their parents for foreign ELT models was an example of indirect resistance to the state's top-down model of English education. Other local actors - the private language institutes and publishers - were, as we have seen, driven by economic motives. Thus, despite the aggressive intervention of the Iranian government in education, the subnational forces have not been passive, obedient entities.

It would, however, be misleading to assign absolute agency to these subnational forces. It is hard to imagine the accomplishments of the private sector without the 'privatization' and 'knowledge-based economy' initiatives of the government. By extension, policies relating to privatization and the knowledge-based economy would not have been implemented without the loan conditions imposed by the World Bank and the UN. In turn, had it not been for the country's major socio-economic problems, the IRI would have not turned to the transnational organizations for help, and would not have implemented the foreign-driven reforms, the unintended outcome of which has been a challenge to the authoritarian state.

In her 2009 book, Bilingual Education in the 21st Century: A Global Perspective, Ofelia Garcia compares language practices to the South Asian banyan trees that 'grow up, out, down, horizontally or vertically through the air until they come upon something solid' (Garcia, 2009: 8). The globalization of certain educational practices bears similar comparison to the banyan tree to explain 
the complexity of the causes and agents of educational transfer in a borderless, market- and information-driven world.

English education in post-revolutionary Iran has been a site of struggle, in which multiple forces compete - forces operating above, below and at nation-state levels; forces with different motives and interests that move upward, downward, vertically and horizontally to interact explicitly or implicitly, voluntarily or by coercion. Like the banyan tree that needs solid ground in which to root, educational transfers are not simply 'traveling policies' moving through the air; they should not be examined in isolation.

The banyan tree of educational transfer we have proposed in this book operates in many directions: from borrowing to lending, from selective to wholesale lessons, from 'real' to 'phony'. It also interacts with competing interests, operating above, below and at nation-state levels, relying on various resources (social, political, economic, educational, ideological, etc.) in order to survive. In the words of Ofelia Garcia (2009: 384), it 'adjusts itself to many soils and contexts'. We hope that the model we have proposed in this book will serve as an effective framework with which to examine systematically the process, causes and agents of educational transfer - and ELT, in particular - in other contexts and soils. 


\section{Appendix: An Overview of the Four Stages of Educational Transfers in Iran (1979-Present)}




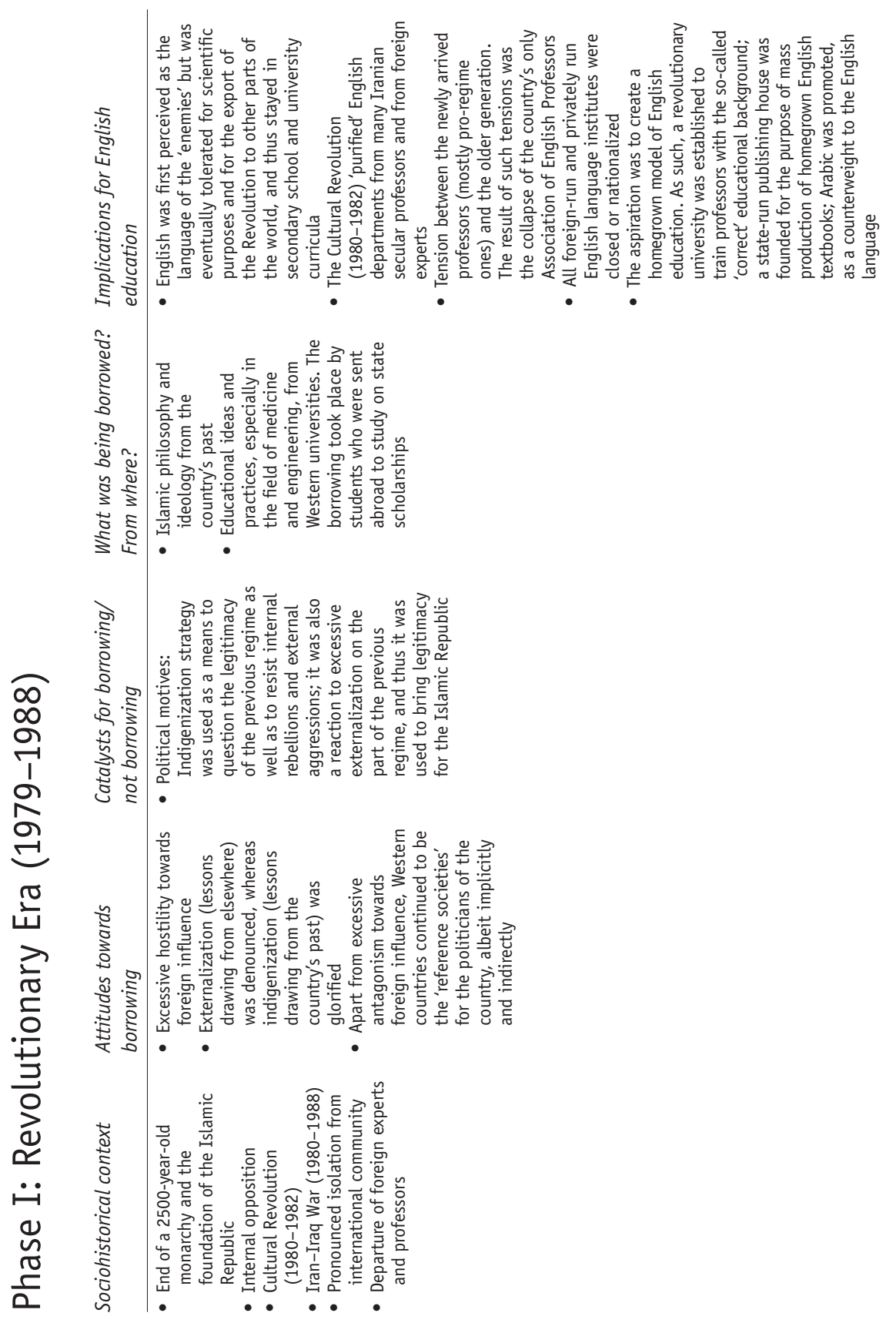




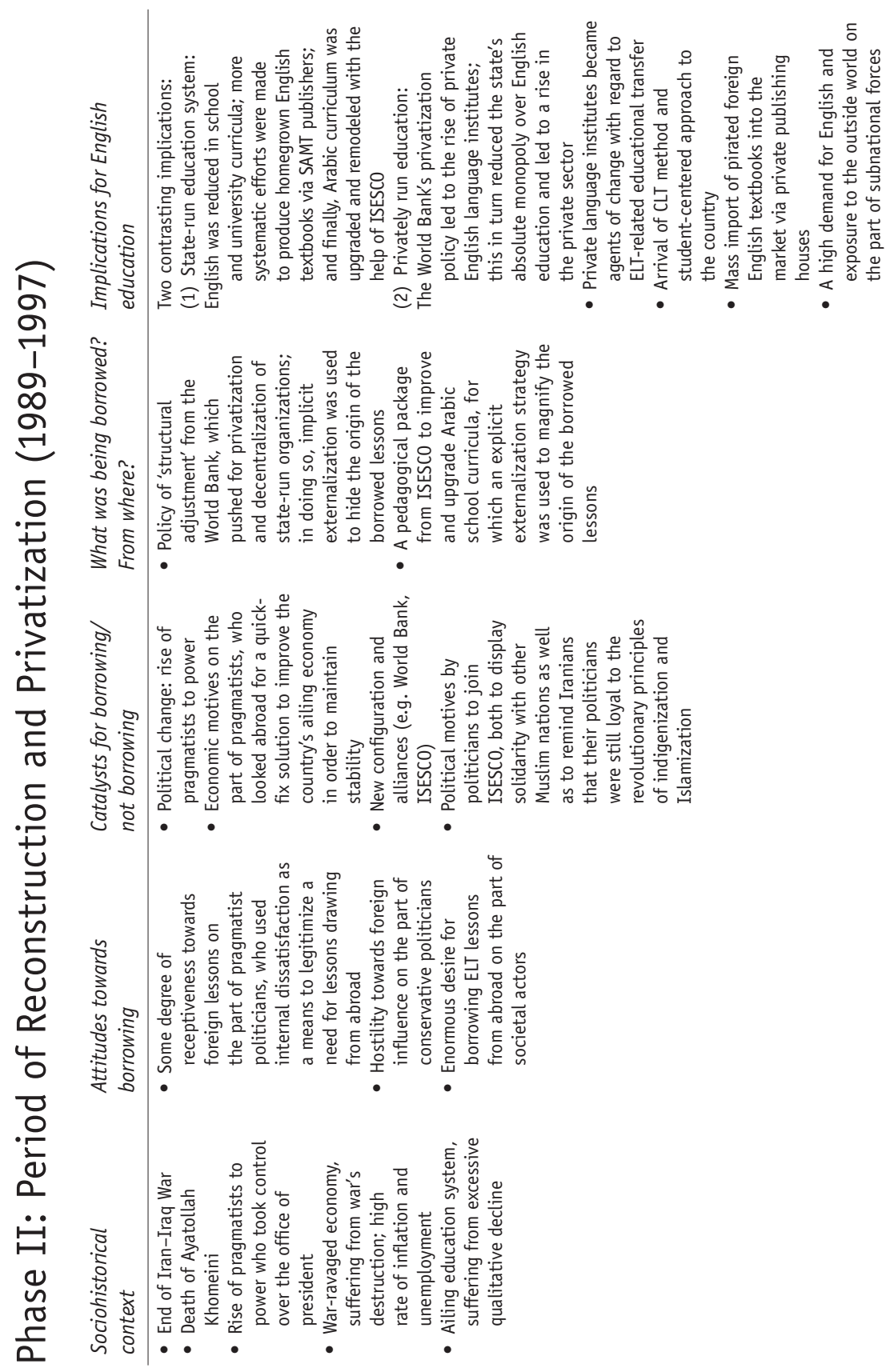




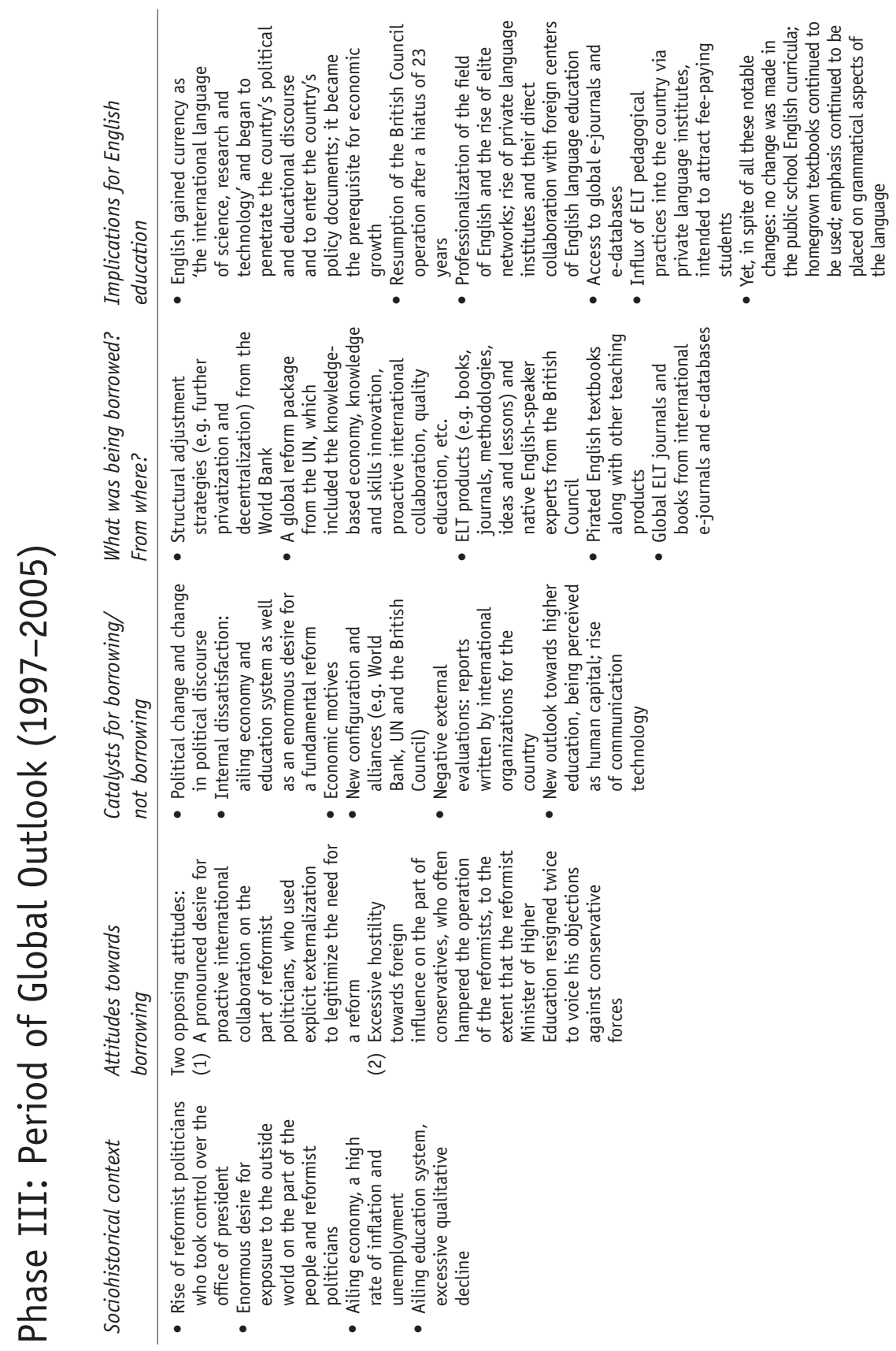



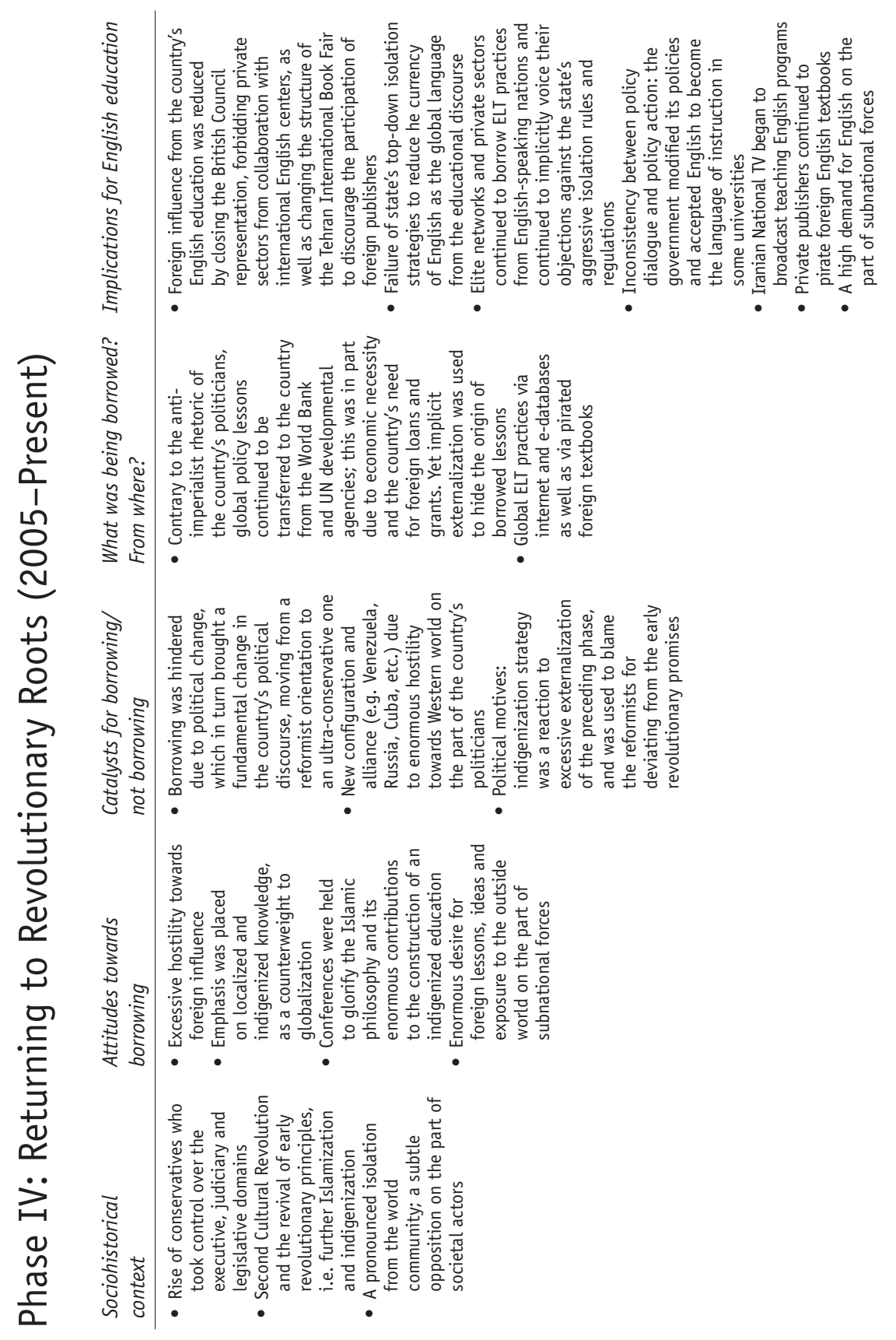


\section{References}

Abrahamian, E. (2008) A History of Modern Iran. Cambridge: Cambridge University Press.

Afary, J. and Anderson, K. (2005) Foucault and the Iranian Revolution: Gender and the Seductions of Islamism. Chicago: University of Chicago Press.

Afshar, N. (2003) English proficiency: A swift pace towards development. Nemud, Journal of the General Office of Scholarship and Overseas Students of the IRI 7, 13.

Ahmadi, A. (2008) SAMT: A giant tree. Online at http://www.samt.ac.ir/index.aspx? siteid=1\&pageid=151, accessed 9 May 2008.

Ahmadi, H. (2007) Thirteen characters of a literate individual. Sima-ye Kharazmi: The Newsletter of Tarbiat Moa'llem University 159 (December), 16-17.

Ahmadinejad, M. (2007) Article title. YNet News, 7 July. http://news.yahoo.com/s/ afp/20070706/pl_afp/irannuclearpoliticsus_070706191852, accessed 29 August 2007.

Ahmadinejad, M. (2008) President Ahmadinejad's speech on research and production of knowledge. Journal of Vanushe: Faslnameh-ye Pazhuheshi, Farhangi o Honari-ye Ostan-e Mazandaran 1 (1-2), i.

Alaghband-Rad, J., Malekzadeh, R. and Mokri, A. (2005) A comparison of R\&D in a few countries of the world. Sharif University Journal 15, 25. Online at http://www.ams. ac.ir/AIM/0141/malekzadeh0141.html, accessed 7 July 2008.

Al-e Dawud (1997) Education: ix. Primary schools. In E. Yarshater (ed.) Encyclopeedia Iranica (Vol. VIII, Fascicle 2) (pp. 199-202). California: Mazda Publishers.

Al-Haq, F. and Samadi, O. (1996) The status of English in the kingdom of Saudi Arabia (KSA) 1940-1990. In J. Fishman, A. Conrad and A. Rubal-Lopez (eds) Post-Imperial English: Status Change in Former British and American Colonies, 1940-1990 (pp. 457-484). Berlin, New York: Mouton de Gruyter.

Altbach, P. and Kelly, G.P. (1984) Education and the Colonial Experience. New Brunswick, NJ: Transaction Books.

Amirahmadi, H. (1988a) From ideology to pragmatic policy in post-revolutionary Iran. In H. Amirahmadi and M. Parvin (eds) Post-Revolutionary Iran (pp. 1-10). Boulder, London: Westview Press.

Amirahmadi, H. (1988b) War damage and reconstruction in the Islamic Republic of Iran. In H. Amirahmadi and M. Parvin (eds) Post-Revolutionary Iran (pp. 126-152). Boulder, London: Westview Press.

Anderson-Levitt, K.M. (2003) A world culture of schooling? In K. Anderson-Levitt (ed.) Local Meaning, Global Schooling: Anthropology and World Culture Theory (pp. 1-26). New York: Palgrave Macmillan. 
Ansari, M. (2005) Management and planning organization of Iran: Official publications. Online at http://www.ifla.org/IV/ifla71/papers/011e-Ansari.pdf, accessed 15 January 2007.

Archambault, R.D. (ed.) (1964) John Dewey on Education: Selected Writings. Chicago: Chicago University Press.

Arjomand, S.A. (2009) After Khomeini: Iran Under his Successors. Oxford: Oxford University Press.

Ashraf, A. (1997) Education: viii. General survey of modern education. In E. Yarshater (ed.) Encyclopoedia Iranica (Vol. VIII, Fascicle 2) (pp. 189-196). California: Mazda Publishers.

Ashraf, A. (2006) Iranian identity. In E. Yarshater (ed.) Encyclopcedia Iranica (Vol. XIII, Fascicle 5) (pp. 507-522). New York: Bibliotheca Persica Press.

Azizi, N. (2006) The Development of Higher Education in Iran (With an Emphasis on Humanities). Tehran: Pazhuheshkadeh-e Motaleat-e Farhangi o Ejtemai.

Bajaj, M. (2010) Intergenerational perspectives on education and employment in the Zambian copperbelt. Comparative Education Review 54 (2), 175-197.

Baker, D. and LeTehndre, G. (2005) National Differences, Global Similarities: World Culture and the Future of Schooling. Stanford: Stanford University Press.

Bakhash, S. (1984) The Reign of the Ayatollahs: Iran and the Islamic Revolution. New York: Basic Books.

Barber, C. (1993) The English Language: A Historical Introduction. Cambridge: Cambridge University Press.

BBC News (2005) Holocaust comments spark outrage. BBC News, 14 December. http:// news.bbc.co.uk/2/hi/middle_east/4529198.stm, accessed 7 July 2008.

BBC News (2007) Farewell to a changed, subtle Iran. BBC News, 7 July. http://news.bbc. co.uk/1/hi/programmes/from_our_own_correspondent/6277172.stm, accessed 5 August 2007.

BBC Persian (2008) The life of Homayun Sanatizadeh. BBC Persian, 3 August. http:// www.bbc.co.uk/persian/arts/story/2008/08/080802_la-cy-sanati.shtml, accessed 9 August 2011.

Beh-Afarin, R. (2005) ELT teacher development: The case of Iran. ILT Language Teaching Journal 1 (1), 75-89.

Bennett, C. (1991) What is policy convergence and what causes it? British Journal of Political Science 21 (2), 215-233.

Bernard, R. (2006) Research Methods in Anthropology: Qualitative and Quantitative Approaches (4th edn). New York: AltaMira Press.

Birashk, A. (1997) Education: x. Middle and secondary schools. In E. Yarshater (ed.) Encyclopoedia Iranica (Vol. VIII, Fascicle 2) (pp. 202-207). California: Mazda Publishers.

Birjandi, P. and Soheili, A. (2000) The 8th Grade English Textbook. Tehran: Organization for Educational Research and Planning.

Block, D. (2002) 'McCommunication': A problem in the frame for SLA. In D. Block and D. Cameron (eds) Globalization and Language Teaching (pp. 117-133). London: Routledge.

Block, D. and Cameron, D. (eds) (2002) Globalization and Language Teaching. London: Routledge.

Block, D., Gray, J. and Holborow, M. (2012) Neoliberalism and Applied Linguistics. London: Routledge.

Blommaert, J. (2010) The Sociolinguistics of Globalization. Cambridge: Cambridge University Press.

Board of Supervision and Assessment of Cultural and Scientific Affairs (2005-2006) A Glance at Science and Technology Situation in the Islamic Republic of Iran. Tehran: Supreme 
Council of Cultural Revolution. http://www.arzyabi.ir/pdf/second_macro_assessment_english_abstract.pdf, accessed 17 January 2009.

Boli, J. and Thomas, G.M. (1999) INGOs and the organization of world culture. In J. Boli and G.M. Thomas (eds) Constructing World Culture. International Nongovernmental Organizations Since 1875 (pp. 3-49). Stanford: Stanford University Press.

Borjian, M. (2008) Isa Sadiq: A short biography and significant contributions. CIEclopedia: WHO's WHO in Comparative and International Education Studies. Online at http:// www.cieclopedia.org, accessed 7 April 2008.

Borjian, M. (2009) English Education in Post-revolutionary Iran: The Politics of Educational Borrowing and Lending. Doctoral dissertation. New York: Teachers College, Columbia University.

Borjian, M. (2010) Policy privatization and empowerment of sub-national forces: The case of private English language institutes in Iran. Higher Education and the Middle East: Serving the Knowledge-Based Economy (Vol. 1) (pp. 58-61). Viewpoints Special Edition. Washington, DC: Middle East Institute. Online at: http://www.mei.edu/ sites/default/files/publications/Education\%20VP.pdf.

Borjian, M. (2011) The rise and fall of a partnership: The British Council and the Islamic Republic of Iran (2001-2009). Journal of Iranian Studies 44 (4): 541-562.

Borjian, M. and Borjian, H. (2007) Isfahan: xv. Education and cultural affairs. In E. Yarshater (ed.) Encyclopoedia Iranica (Vol. XIV, Fascicle 1) (pp. 67-71). New York: Encyclopædia Iranica Foundation.

Borjian, M. and Borjian, H. (2011) Plights of Persian in the modernization era. In J. Fishman and O. Garcia (eds) Handbook of Language and Ethnic Identity: The SuccessFailure Continuum in Language and Ethnic Identity Efforts (Vol. 2) (pp. 254-267). New York: Oxford University Press.

Borumand, S. (2002) The Operation of British Church Missionary Society (CMS) in Iran Under Qajar Dynasty. Tehran: Moassese-ye Motaleat-e Tarikh-e Moaser-e Iran.

Boyce, A.C. (1954) Alborz College of Tehran and Dr. Samuel Martin Jordan, Founder and President. California: Duarte.

Brettell, C. (1998) Fieldwork in the archives: Methods and sources in historical anthropology. In H.R. Bernard (ed.) Handbook of Methods in Cultural Anthropology (pp. 513-546). Walnut Creek, CA: AltaMira.

British Council Iran (2007) Website. http://www.britishcouncil.org/iran.htm, accessed 21 August 2007.

Brock-Utne, B. (2001) Education for all - in whose language? Oxford Review of Education 27 (1), 115-133.

Brutt-Griffler, J. (2002) World English: A Study of its Development. Clevedon: Multilingual Matters.

Bunyi, G. (2005) Language classroom practices in Kenya. In A. Lin and P.W. Martin (eds) Decolonization, Globalization: Language-in-Education Policy and Practices (pp. 131-152). Clevedon: Multilingual Matters.

Bureau for the Coordination of Projects and Programs (1997) Educational Statistics 19881997. Tehran: Ministry of Education.

Cameron, D. (2002) Globalization and the teaching of 'communication skills'. In D. Block and D. Cameron (eds) Globalization and Language Teaching (pp. 67-82). London: Routledge.

Canagarajah, A.S. (1999) Resisting Linguistic Imperialism in English Teaching. Oxford: Oxford University Press.

Canagarajah, A.S. (2005a) Reclaiming the Local in Language Policy and Practice. Mahwah, NJ: Lawrence Erlbaum. 
Canagarajah, A.S. (2005b) Accommodating tensions in language-in-education policies: An afterword. In A. Lin and P.W. Martin (eds) Decolonization, Globalization: Languagein-Education Policy and Practices (Vol. I) (pp. 194-201). Clevedon: Multilingual Matters.

Catanzaro, C. (2001) German cultural influence in Persian. In E. Yarshater (ed.) Encyclopoedia Iranica. Online at http://www.iranica.com/articles/germany-vii.

Cleaver, F. (1999) Paradoxes of participation: Questioning participatory approaches to development. Journal of International Development 11 (4): 597-612.

Corona, D. and Garcia, O. (1996) English in Cuba: From the imperial design to the imperative needs. In J. Fishman, A. Conrad and A. Rubal-Lopez (eds) Post-imperial English: Status Change in Former British and American Colonies, 1940-1990 (pp. 85-110). Berlin: Mouton de Gruyter.

Cresswell, J.W. (2007) Research Design: Qualitative, Quantitative, and Mixed Method Approaches. Thousand Oaks, London: Sage Publications.

Crystal, D. (1997) English as a Global Language. New York: Cambridge University Press.

Crystal, D. (2001) Language and the Internet. Oxford: Oxford University Press.

David, M.K. and Govindasamy, S. (2005) Negotiating a language policy for Malaysia: Local demand for affirmative action versus challenges from globalization. In S. Canagarajah (ed.) Reclaiming the Local in Language Policy and Practice (pp. 123-146). Mahwah, NJ: Lawrence Erlbaum.

Deedari, M., Ziahosseiny, M. and Varzegar, M. (1990) English for Students of Medicine. Tehran: SAMT.

Deghanpisheh, B. (2007) Bear hugs. World Press Review, 5 March. Online at http://www. worldpress.org/Mideast/1185.cfm, accessed 30 June 2008.

Dehqani-Tafti, H. (1994) In the memory of Isfahan College and his great founder, Rev. William Jameson Thompson. Rahavard 36, 253-257.

EIr. (1989) British Council. In E. Yarshater (ed.) Encyclopcedia Iranica (Vol. IV, Fascicle 5) (pp. 455-456). London, New York: Routledge and Kegan Paul.

EIr. (1997) Education: xv. Foreign and minority schools in Persia. In E. Yarshater (ed.) Encyclopoedia Iranica (Vol. VIII, Fascicle 2) (p. 214). California: Mazda Publishers.

Ellis, G. (1996) How culturally appropriate is the communicative approach? ELT Journal 50 (3), 213-218.

Emami, K. (1993) Copyright. In E. Yarshater (ed.) Encyclopoedia Iranica (Vol. VI) (pp. 264266). Costa Mesa, CA: Mazda Publishers.

Entezarkheir, M. (2005) Why is Iran experiencing migration and brain drain to Canada? Online at http://www.academia.edu/248531/Why_is_Iran_Experiencing_Migration_ and Brain Drain to Canada? accessed 6 June 2008.

Farhady, H. (1994) On the specificity of purpose in ESP. In A. Miremadi (ed.) The Proceedings of the Second International Conference in Linguistics and Applied Linguistics. Tehran: Allameh Tabatabai University Press.

Farhady, H. (2006) Reflections on and directions for ESP materials development in SAMT. In G. Kiany and M. Khayyamdar (eds) Proceedings of the First National ESP/EAP Conference (Vol. 3) (pp. 2-32). Tehran: Center for Research and Development of Humanities of SAMT.

Farhady, H. (2007) Teaching and testing in Iran. Global trends and local dilemmas. Journal of Teaching English Language and Literature Society of Iran (TELLSI) 1 (2), 75-94.

Farhady, H., Jafarpoor, A. and Birjandi, P. (1994) Language Skills Testing: From Theory to Practice. Tehran, SAMT.

Farhikhtegan (2008) Islamic Azad University: The serving arm of the regime. Islamic Azad University Newspaper 27 May, 9. 
Ferrier, R.W. (1987) Anglo-Iranian relations: iii. Pahlavi period. In E. Yarshater (ed.) Encyclopeedia Iranica (Vol. II) (pp. 51-59). London, New York: Routledge and Kegan Paul.

First Five-Year Plan (1989) First Five-Year Economic, Social and Cultural Development Plan 1989-1994. Tehran: Plan and Budget Organization.

Fischer, M. (1983) Imam Khomeini: Four levels of understanding. In J. Esposito (ed.) Voices of Resurgent Islam (pp. 150-174). New York, Oxford: Oxford University Press.

Fishman, J. (1969) National languages and languages of wider communication in the developing nations. Anthropological Linguistics 11 (4), 111-135.

Fishman, J., Solano, F.R. and McConnell, G.D. (1991) A methodological check on three cross-polity studies of linguistic homogeneity/heterogeneity. In M.E. McGroarty and C.J. Faltis (eds) Language in School and Society: Policy and Pedagogy (pp. 21-30). Berlin, New York: Mouton de Gruyter.

Foran, J. and Goodwin, J. (1993) Revolutionary outcomes in Iran and Nicaragua: Coalition fragmentation, war, and the limits of social transformation. Theory and Society 22 (2), 209-247.

Foucault, M. (1972) The Archaeology of Knowledge. New York: Harper \& Row.

Fourth Five-Year Plan (2004) Fourth Five-Year Economic, Social and Cultural Development Plan 2005-2009. Tehran: Plan and Budget Organization.

Francis-Dehqani, G.E. (2008) Great Britain: xv. British schools in Persia. In E. Yarshater (ed.) Encyclopoedia Iranica. Online at http://www.iranicaonline.org/articles/greatbritain-xv, accessed 7 April 2008.

Frank, A.G. (1966) The development of underdevelopment. Monthly Review 18 (4), 17-31.

Garcia, O. (2009) Bilingual education in the 21st century: A global perspective. Malden, MA: Wiley-Blackwell.

German Language Institute of Tehran (2008) Website. http://www.teheran.diplo.de/ Vertretung/teheran/fa/Startseite.html, accessed 2 March 2008.

Gill, S.K. (2005) Language policy in Malaysia: Reversing direction. Language Policy 4, $241-260$.

Graddol, D. (2010) English Next India. London: British Council.

Gray, J. (2002) The global coursebook in English language teaching. In D. Block and D. Cameron (eds) Globalization and Language Teaching (pp. 151-167). London: Routledge.

Habibi, N. (1989) Allocation of educational and occupational opportunities in the Islamic Republic of Iran: A case study in the political screening of human capital in the Islamic Republic of Iran. Iranian Studies 22 (4), 19-46.

Hadidi, J. (1994) France: xv. French schools in Persia. Encyclopeedia Iranica. Online at http://www.iranicaonline.org/articles/france-Xv.

Hambly, G. (1991) The Pahlavi autocracy: Reza Shah, 1921-1941. In P. Avery, G. Hambly and C. Melville (eds) The Cambridge History of Iran (Vol. 7): From Nadir Shah to the Islamic Republic (pp. 213-243). Cambridge: Cambridge University Press.

Hanson, J. (1997) The mother of all tongues. Review of D. Crystal, 'English as a Global Language'. The Times Higher Education Supplement 1288, 11 July, 22.

Harlow, D.J. (1998) Esperanto: An overview, wiki article. http://en.wikipedia.org/wiki/ Esperanto, accessed 28 December 2008.

Harrison, F. (2006) Mass purges at Iran universities. BBC News, 20 December. http:// news.bbc.co.uk/1/hi/world/middle_east/6196069.stm, accessed 2 February 2008.

Harrison, F. (2007) Huge cost of Iranian brain drain. BBC News, 8 January. http://news. bbc.co.uk/2/hi/middle_east/6240287.stm, accessed 6 May 2008.

Hashemi-Rafsanjani, A. (1982) Hashemi-Rafsanjani. Iran Times, 5 November.

Hazeri, A.M. (1993) The Process of Sending Students Abroad. Tehran: SAMT. 
Hendershot, C. (1975) Politics, Polemics and Pedagogs: A Study of the United States Technical Assistance in Education to Iran, Including Negotiations, Political Considerations in Iran and the United States, Programming, Methods, Problems, Results, and Evaluations. New York, Washington, Atlanta: Vantage Press.

Holliday, A. (1994) Appropriate Methodology and Social Context. Cambridge: Cambridge University Press.

Holliday, A. (2005) The Struggle to Teach English as an International Language. Oxford: Oxford University Press.

Howlett, M. and Ramesh, M. (1995) Studying Public Policy: Policy Cycles and Policy Subsystems. Oxford: Oxford University Press.

Hymes, D. (1971) Competence and performance in linguistic theory. In R. Huxley and E. Ingram (eds) Language Acquisition: Models and Methods. London: Academic Press.

IJAL (2008) Iranian Journal of Applied Linguistics. http://www.tmu.ac.ir/ijal/index.html, accessed 13 April 2008.

ILI Journal (2008) Iran Language Institute Language Teaching Journal. http://www.ili. ir/e.teaching_journal.htm, accessed 8 December 2008.

Infinity (2008) Globalization and higher education. Islamic Azad University Newsletter 9, April 2008, 2.

Inside Iran (2007) Dr. Kian Tajbakhsh professor was detained. Inside Iran, 24 May.

International Telecommunications Union $(2008,2011)$ http://www.itu.int/ITU-D/ict/ statistics/index.html, accessed 2 June 2008 and 1 September 2011.

Iran Daily (2007) The unauthorized activities of the British Council. Iran English Daily News, 23 May. China people daily online: http://english.peopledaily.com.cn/200705/23/ eng20070523_377237.html, accessed October 2007.

Iran Language Institute (2008) A historical overview. Website article. http://www.ili.ir/e. prof.htm, accessed January 2007.

Iran University Press (2011) History and its track record. http://www.iup.ir/index. aspx? pid $=$ 95062, accessed 9 August 2011.

Irani, H. (2006) Cleaning in the names of retirement, wiki article. http://en.wikipedia. org/wiki/Mahmoud_Ahmadinejad\#cite_note-72, accessed 14 June 2008.

IRI Constitution (1996) Ōnline at http://www.ïranonline.com/iran/iran-info/Government/ constitution.html, accessed 5 June 2007.

ISESCO (2008) Website. http://www.isesco.org.ma.

Jones, P.W. (2004) Taking the credit: Financing and policy linkages in the education portfolio of the World Bank. In G. Steiner-Khamsi (ed.) The Global Politics of Educational Borrowing and Lending (pp. 188-200). New York: Teachers College, Columbia University.

Karimkhanlui, G. (2005) EAP and the communicative use of language. In R. Kiany and M. Khayyamdar (eds) Proceeding of the First National ESP/EAP Conference (Vol. II) (pp. 51-69). Tehran: SAMT.

Karmani, S. (2005) Petro-linguistics: The emerging nexus between oil, English, and Islam. Journal of Language, Identity, and Education 4 (2), 87-102.

Keohane, R.O. and Nye, J.S. (1989) Power and Interdependence. Glenview, IL: Scott Foresman. Khatami, M. (2000) Zanan va Javanan [Women and Youth]. Tehran: Terh-e No Publications. Khatami, M. (2001) Mardomsalari [Democracy]. Tehran: Tarh-e No Publications.

Khazaifar, A., Khavari, G.H. and Rezai, A.A. (2000) English for the Students of Humanities II. Tehran: SAMT.

Khomeini, R. (1979) Khomeini's interview with Ettelaat Newspaper, 31 October. Brain drain in Iran, wiki article. http://en.wikipedia.org/wiki/Iran\%27s_brain_drain, accessed 12 October 2007. 
Khomeini, R. (1980a) Islamic universities: We say that universities should be Islamic fundamentally. Speech by Khomeini, April. http://www.iranculture.org/about/ rahbar/emam/e01.php, accessed 6 January 2008.

Khomeini, R. (1980b) The foundation of the Headquarters of the Cultural Revolution. Speech by Khomeini, November. http://www.iranculture.org/about/rahbar/emam/ e01.php, accessed 6 January 2008.

Kiany, R. and Khayyamdar, M. (eds) (2005-2006) Proceedings of the First National ESP/EAP Conference (3 vols). Tehran: SAMT.

La'li, M. (ed.) (1999) Khatami az cheh miguyad? Majmu'eh sokhanrani-ha [What is Khatami talking about? A collection of speeches]. Tehran: Ekhlas Publications.

Larsen-Freeman, D. (2000) Techniques and Principles in Language Teaching. Oxford: Oxford University Press.

LeCompte, M. and Preissle, J. (1993) Ethnography and Qualitative Design in Educational Research (2nd edn). San Diego, CA: Academic Press.

Lentz, H.M. (1986) Farrokhrou Parsa: Assassinations and executions. An Encyclopedia of Political Violence 1865-1986. Jefferson: McFarland.

Lin, A. and Martin, P.W. (eds) (2005) Decolonization, Globalization: Language-in-Education Policy and Practices. Clevedon: Multilingual Matters.

Lindblad, S. and Popkewitz, T.S. (eds) (2004) Educational Restructuring. International Perspectives on Traveling Policies. Greenwich: Information Age Publishing.

List of Universities and Colleges in Tehran (2007) List of universities in Tehran Province, wiki article. http://en.wikipedia.org/wiki/List_of_Universities_in_Tehran_Province, accessed June 2007.

Lo Bianco, J., Orton, J. and Yihong, G. (eds) (2009) China and English: Globalisation and the Dilemmas of Identity. Bristol: Multilingual Matters.

Luschei, T. (2004) Timing is everything: The intersection of borrowing and lending in Brazil's adoption of Escuela Nueva. In G. Steiner-Khamsi (ed.) The Global Politics of Educational Borrowing and Lending (pp. 154-167). New York: Teachers College, Columbia University.

Majdzadeh-Tabatabai, M. (2006) National identity and civic values in the pre-revolution and post-revolution English as a foreign language textbooks in Iran. Doctoral dissertation, Loyola University, Chicago, IL.

Malekzadeh. R., Mokri, A. and Azarmina, P. (2007) Medical science and research in Iran. Online at http://www.ams.ac.ir/AIM/0141/malekzadeh0141.html, accessed 6 March 2008.

Mansoori, A. (1986) American Missionaries in Iran, 1834-1934. Doctoral dissertation, Ball State University, Muncie, IN.

Mazrui, A. (1997) The World Bank, the language question and the future of African education. Race and Class: A Journal for Black and Third World Liberation 3, 35-49.

Mazrui, A. (2004) English in Africa after the Cold War. Clevedon: Multilingual Matters.

Mazrui, A.A. and Mazrui. A.M. (1998) The Power of Babel: Language and Governance in the African Experience. Chicago: Chicago University Press.

McArthur, T. (1998) The English Languages. Cambridge: Cambridge University Press.

McMichael, P. (1996) Development and Social Change: A Global Perspective. Thousand Oaks, CA: Pine Forge Press.

Mehran, G. (1997) xxiv. Education in postrevolutionary Persia, 1979-1995. In E. Yarshater (ed.) Encyclopeedia Iranica (Vol. VIII, Fascicle 2). California: Mazda Publishers. http:// www.iranicaonline.org/articles/education-xxiv-education-in-postrevolutionary-persia1979-95, accessed 10 October 2007. 
Mehran, G. (2003) Khatami, political reform and education in Iran. Comparative Education 39 (3), 311-329.

Mehrdadm (2012) Launching the national internet. Iranian.com, 19 September. http:// www.iranian.com/main/2012/sep/iran-prepares-launch-national-internet.

Menashri, D. (1997) Education: xvii. Higher education. In E. Yarshater (ed.) Encyclopedia Iranica (Vol. VIII, Fascicle 2). California: Mazda Publishers. http://www.iranicaonline.org/articles/education-xvii-higher-education, accessed 10 October 2007.

Meyer, J., Ramirez, F.O., Rubinson, R. and Boli-Bennett, J. (1977) The world educational revolution, 1950-1970. Sociology of Education 50, 242-258.

Milani, M. (1993) The evolution of the Iranian presidency: From Bani Sadr to Rafsanjani. British Journal of Middle Eastern Studies 20 (1), 83-97.

Mina, H. (2004) Fragments of Memories: A Story of a Syrian Family (O. Kenny and L. Kenny, trans.). Northampton, MA: Interlink Books.

Mirzai, D. (2007) Ahmadinejad attacks the Tehran book fair. AsiaNews, 12 April. http:// www.asianews.it/index.php?art=8975\&l=en, accessed 20 May 2008.

Mo'in, M. (2004) An interview with Mostafa Mo'in, blog post. http://drmoeen.ir/biography.php.

Namaghi, A. (2006) Forces steering Iranian language teachers' work: A grounded theory. Reading Matrix 6 (2), 90-105.

Nateq, H. (1996) Karname-ye farhangi-ye Farangi dar Iran. Paris: Khavaran Publishers.

NBC News. (2004) Iran says it arrested Iranian-American scholar. NBCNews, 14 May. http://www.msnbc.msn.com/id/18644130/, accessed 14 July 2007.

NBC News (2007) Ahmadinejad: Iran's nuclear issue is 'closed'. NBCNews, 25 September. http://www.msnbc.msn.com/id/20969975/, accessed 12 July 2008.

OECD (2008) Gross domestic expenditure on R\&D: As a percentage of GDP, 2006 or latest available year, in OECD Factbook 2008, OECD Publishing. doi: 10.1787/ factbook-2008-graph104-en

OECD Factbook (2008) Online at http://titania.sourceoecd.org, accessed 23 July 2008.

OERP (2008) Organization for Educational Research and Planning. oerp@medu.ir, accessed 2 January 2008.

Omeedvar (2012) The stoning of YouTube. Iranian.com, 9 January. http://www.iranian. $\mathrm{com} / \mathrm{main} / \mathrm{blog} / \mathrm{omeedvar}-3$.

Ouyang, H. (2003) Resistance to the communicative method of language instruction within a progressive Chinese university. In K.M. Anderson-Levitt (ed.) Local Meaning, Global Schooling: Anthropology and World Culture Theory (pp. 121-140). New York: Palgrave Macmillan.

Paul, L. (1999) Iranian nation and Iranian-Islamic revolutionary ideology. Die Welt des Islams 39 (2), 183-217.

Peet, R. (with E. Hartwick) (1999) The Rise of Development. New York, London: Guilford Press.

Peirce, B.N. (1989) Toward a pedagogy of possibility in the teaching of English internationally. TESOL Quarterly 23, 401-420.

Pennycook, A. (1989) The concept of method, interested knowledge and the politics of language teaching. TESOL Quarterly 23, 589-618.

Pennycook, A. (1998) English and the Discourse of Colonialism. London: Routledge.

Pennycook, A. (2001) Critical Applied Linguistics: A Critical Introduction. Mahwah, NJ: Lawrence Erlbaum.

Pennycook, A. (2004) The myth of English as an international language. Literacy Learning: The Middle Years/English in Australia 12, 26-32.

Pennycook, A. (2007) Global Englishes and Transcultural Flows. London: Routledge. 
Perkins, J. (1843) A Residence of Eight Years in Persian, Among the Nestorian Christians with Notices of Muhammedans. Andover, MA: Allen, Morril \& Wardwell.

Phillips, D. (2000) Learning from elsewhere in education: Some perennial problems revisited with reference to British interest in Germany. Comparative Education 36 (3), 297-307.

Phillips, D. (2004) Toward a theory of policy attraction in education. In G. SteinerKhamsi (ed.) The Global Politics of Educational Borrowing and Lending (pp. 54-67). New York: Teachers College, Columbia University.

Phillips, D. and Ochs, K. (2003) Process of policy borrowing in education: Some analytical and explanatory devices. Comparative Education 39 (4), 451-461.

Phillipson, R. (1992) Linguistic Imperialism. Oxford: Oxford University Press.

Phillipson, R. and Skutnabb-Kangas, T. (1994) English, panacea or pandemic? Sociolinguistica 8, 73-87.

Plan and Budget Organization of the IRI (2008) http://www.spac.ir/Portal/Home.

Probyn, M. (2005) Language and the struggle to learn: The intersection of classroom realities, language policy and neocolonial and globalization discourse in South African schools. In A. Lin and P.W. Martin (eds) Decolonization, Globalization: Language-inEducation Policy and Practices (pp. 153-171). Clevedon: Multilingual Matters.

Qasemi-Puya, A. (1998) Modern Schools in Qajar Era. Tehran: Markaz-e Nashr-e Daneshgah-i.

Rahman, T. (2005) The Muslim response to English in south Asia: With special reference to inequality, intolerance, and militancy in Pakistan. Journal of Language, Identity, and Education 4 (2), 119-135.

Ramirez, F.O. and Meyer, J. (2002) National curricula: World models and national historical legacies. In M. Caruso and $\mathrm{H}$. Tenorth (eds) Internationalisation. Comparing Educational Systems and Semantics (pp. 91-107). Frankfurt: Lang.

Reagan, T. and Schreffler, S. (2005) Higher education language policy and the challenges of linguistic imperialism: A Turkish case study. In A. Lin and P.W. Martin (eds) Decolonization, Globalization: Language-in-Education Policy and Practices (pp. 115-130). Clevedon: Multilingual Matters.

Reuters (2007) Iran sees a 'creeping coup' in the press. Reuters report. Online at http:// www.reuters.com/article/worldNews/idUSBLA75225420070707, accessed 14 July 2007.

Riazi, A. (2005a) The four language stages in the history of Iran. In A. Lin and P.W. Martin (eds) Decolonization, Globalization: Language-in-Education Policy and Practices (Vol. I) (pp. 98-114). Clevedon: Multilingual Matters.

Riazi, A. (2005b) Features of quality EAP textbooks: Insights from literature and book reviews. In R. Kiany and M. Khayyamdar (eds) Proceedings of the First National ESP/ EAP Conference (pp. 35-44). Tehran: SAMT.

Rice, C. (2007) Iran becoming increasingly dangerous, says Rice. YNet News, 7 July. http:// www.ynetnews.com/articles/0,7340,L-3422123,00.html, accessed 29 August 2007.

Richards, J.C., Platt, J. and Platt, H. (1992) Longman Dictionary of Applied Linguistics. London: Longman.

Ringer, M. (2001) Education, Religion, and the Discourse of Cultural Reform in Qajar Iran. Costa Mesa, CA: Mazda Publishers.

Robertson, S., Bonal, X. and Dale, R. (2002) GATS and the education service industry: The politics of scale and global reterritorialization. Comparative Education Review 46 (4), 427-496.

Rooz (2006) Protest against the second Cultural Revolution. Rooz Online, 18 October. http://en.wikipedia.org/wiki/Mahmoud_Ahmadinejad, accessed 24 June 2008. 
Rose, R. (1993) Lesson-Drawing in Public Policy: A Guide to Learning Across Time and Space. Chatham, NJ: Chatham House.

Rostow, W.W. (1960) The Stages of Economic Growth: A Non-Communist Manifesto. Cambridge: Cambridge University Press.

Rubdy, R. (2005) Remarking Singapore for the new age: Official ideology and the realities of practice in language-in-education. In A. Lin and P.W. Martin (eds) Decolonization, Globalization: Language-in-Education Policy and Practices (pp. 55-73). Clevedon: Multilingual Matters.

Sabatier, P.A. and Jenkins-Smith, H.C. (1993) Policy Change and Learning: An Advocacy Coalition Approach. Boulder, Oxford: Westview Press.

Sadiq, I. (1942) One Year in the America. Tehran: Parvin Publication House.

Sadiq, I. (1974) The Memory of a Life (Vol. 3). Tehran: Tehran University Press.

Saffarzadeh, T. (1990) Preface. In R. Deedari, M. Ziahosseiny and M. Varzegar (eds) English for Students of Medicine. Tehran: SAMT.

Saikal, A. (1991) Iranian foreign policy, 1921-1979. In P. Avery, G. Hambly and C. Melville (eds) The Cambridge History of Iran (Vol. 7): From Nadir Shah to the Islamic Republic (pp. 426-458). Cambridge: Cambridge University Press.

SAMT (2008) The Organization for Researching and Composing University Textbooks in the Humanities. Website. http://www.samt.ac.ir.

Schriewer, J. (2000) World system and interrelationship networks: The internationalization of education and the role of comparative inquiry. In T.S. Popkewitz (ed.) Educational Knowledge: Changing Relationships Between the State, Civil Society, and the Educational Community (pp. 305-433). Albany: State University of New York Press.

Schriewer, J. (2003) Globalization in education: Process and discourse. Policy Futures in Education 1 (2), 271-283.

Schriewer, J. (2004) Multiple internationalities: The emergence of a world-level ideology and the persistence of idiosyncratic world-views. In C. Charle, J. Schriewer and P. Wagner (eds) Transnational Intellectual Networks (pp. 473-534). Frankfurt, New York: Campus Verlag.

Schriewer, J. and Martinez, C. (2004) Constructions of internationality in education. In G. Steiner-Khamsi (ed.) The Global Politics of Educational Borrowing and Lending (pp. 29-53). New York: Teachers College, Columbia University.

Second Five-Year Plan (1994) Second Five-Year Economic, Social and Cultural Development Plan 1995-1999. Tehran: Plan and Budget Organization.

Seyfpur-Fatemi, N. (1989) Aineye Ebrat. London: Nashr-e Ketab.

Shahidi, H. (2001) The BBC Persian service, 1940-1953, and the naturalization of Iranian oil. Journal of Iranian Research and Analysis 17, 31-55.

Shahsavani, A. (2008) A comprehensive plan of the memorization and understanding of Koran. Interview with Ayatollah Shahsavani. Iran National Radio, 8 July.

Sharabi, H. (2008) Embers and Ashes: Memoirs of an Arab Intellectual (J. Boullata, trans.). Northampton, MA: Olive Branch Press.

Shorish, M.M. (1988) The Islamic revolution and education in Iran. Comparative Education Review 32 (1), 58-75.

Shultz, T.W. (1971) Investment in Human Capital: The Role of Education and Research. New York: Free Press.

Siegel, R.L. and Weinberg, L.B. (1977) Comparing Public Policies: United States, Soviet Union and Europe. Homewood, IL: Dorsey Press. 
Silova, I. (2004) Adopting the language of the new allies. In G. Steiner-Khamsi (ed.) The Global Politics of Educational Borrowing and Lending (pp. 75-87). New York: Teachers College, Columbia University.

Skutnabb-Kangas, T. (2006) Language policy and linguistic human rights. In T. Ricento (ed.) An Introduction to Language Policy (pp. 273-291). Malden, MA: Blackwell Publishing.

Slocum, J.B. (1970) Iran: A Study of the Educational System and Guide to the Admission and Academic Placement of Iranian Students in Colleges and Universities in the United States. Washington, DC: American Association of Collegiate Registrars and Admissions Officers.

Smith, D. (2000) Franklin Book Program. In E. Yarshater (ed.) Encyclopcedia Iranica (Vol. X, Fascicle 2), (pp. 187-190). Online at http://iranica.com/articles/franklin-book-program.

Sobhe, K. (1982) Education in revolution: Is Iran duplicating the Chinese Cultural Revolution? Comparative Education 18 (3), 271-280.

Soleimani, H. (2006) EAP in Iran: Drawbacks of SAMT EAP textbooks. In G. Kiany and M. Khayyamdar (eds) Proceedings of the First National ESP/EAP Conference (Vol. 3) (pp. 216-228). Tehran: Center for Research and Development of Humanities of SAMT.

Spolsky, B. (2004) Language Policy. Cambridge: Cambridge University Press.

Steiner-Khamsi, G. (2003) The politics of league tables. OJSSE 1. http://www.sowionlinejournal.de/2003-1/tables khamsi.htm, accessed 16 July 2006.

Steiner-Khamsi, G. (2004) The Global Politics of Educational Borrowing and Lending. New York: Teachers College, Columbia University.

Steiner-Khamsi, G. and Quist, H. (2000) The politics of educational borrowing: Reopening the case of Achimota in British Ghana. Comparative Education Review 44 (3), 272-299.

Steiner-Khamsi, G. and Stolpe, I. (2006) Educational Import: Local Encounters with Global Forces. New York: Palgrave Macmillan.

Stiglitz, J. (2003) Globalization and its Discontents. New York, London: W.W. Norton.

Supreme Council (1985-2008) A total number of 1568 official regulations issued by the Supreme Council of Cultural Revolution. http://www.iranculture.org, accessed November 2007-April 2008.

Supreme Council of the Cultural Revolution (2008) Website. http://www.iranculture.org, accessed winter 2008.

Tait, R. (2006) Iranian president calls for purge of liberal lecturers. Guardian, 6 September. http://education.guardian.co.uk/higher/worldwide/story/0,,1865731,00.html, accessed 2 February 2008.

TELLSI (2011) Teaching English Language and Literature Society of Iran. Website. http:// www.tellsi.ir/, accessed 28 August 2011.

Ter-Minasova, A. (2005) Traditions and innovations: English language teaching in Russia. World Englishes 24 (4), 445-454.

Third Five-Year Plan (1999) Third Five-Year Economic, Social and Cultural Development Plan 2000-2004. Tehran: Plan and Budget Organization.

Thompson, W.J. (1945) Iran: 1939-1944. Journal of the Central Asiatic Society 32, 34-43.

Tollefson, J. (1991) Planning Language, Planning Inequality: Language Policy in the Community. New York: Longman.

Tollefson, J. (2000) Policy and ideology in the spread of English. In J. Kelly Hall and W. Eggington (eds) The Sociopolitics of English Language Teaching (pp. 7-21). Clevedon: Multilingual Matters.

Tollefson, J. and Tsui, A. (eds) (2004) Medium of Instruction Policies: Which Agenda? Whose Agenda? Mahwah, NJ: Lawrence Erlbaum.

Tyack, D. and Tobin, W. (1993) The grammar of schooling: Why has it been so hard to change? American Educational Research Journal 31 (3), 453-479. 
UN (1999) Human Development Report of the Islamic Republic of Iran. Tehran: United Nations and Plan and Budget Organization of the IRI.

UN (2003) United Nations Common Country Assessment (CCA) for the IRI. Tehran: United Nations Country Team in Iran and Plan and Budget Organization of the IRI.

UN (2004a) First Millennium Development Goals Reports: Achievements and Challenges. Tehran: United Nations and the Institute for Management and Planning Studies in the IRI.

UN (2004b) United Nations Development Assistance Framework (UNDAF) for the IRI: 2005-2009. Tehran: United Nations Country Team in Iran and Plan and Budget Organization of the IRI. http://planipolis.iiep.unesco.org/upload/Iran/Iran\%20UNDAF.pdf.

Vavrus, F. (2002) Postcoloniality and English: Exploring language policy and the politics of development in Tanzania. TESOL Quarterly 36 (3), 373-379.

Vavrus, F. (2004) The referential web: Externalization beyond education in Tanzania. In G. Steiner-Khamsi (ed.) The Global Politics of Educational Borrowing and Lending (pp. 141-153). New York: Teachers College, Columbia University.

Vavrus, F. and Bartlett, L. (2006) Comparatively knowing: Making a case for the vertical case study. Current Issues in Comparative Education 8 (2), 95-103.

Vick, K. (2005) Hard line figure in Iran runoff. Washington Post, 19 June. http://www. washingtonpost.com/wp-dyn/content/article/2005/06/18/AR2005061801226.html.

Wallerstein, I. (1979) The Capitalist World Economy. New York: Cambridge University Press.

Warschauer, M. (2000) The changing global economy and the future of English teaching. TESOL Quarterly 34, 511-535.

Weiss, M.A. and Sanford, J.E. (2008) CRS Report for Congress: The World Bank and Iran. Online at http://www.fas.org/sgp/crs/mideast/RS22704.pdf, accessed 17 August 2008.

Wheeler, E. (1994) Ornaments of Fire: The World's Best 101 Short Poems and Fragments. Santa Barbara: Fithian Press.

White, B.W. (1996) Talk about school: education and the colonial project in French and British Africa (1860-1960). Comparative Education 32 (1), 9-25.

Whitlock, N. (2007) Trouble at the Tehran book fair. Quill and Quire, 1 May. http://www. quillandquire.com/blog/index.php/news/2007/05/01/trouble-at-the-tehran-bookfair/, accessed 20 May 2008.

Widdowson, H.G. (1999) Coming to terms with reality: Applied linguistics in perspective. Plenary Address to the 12th World Congress of Applied Linguistics. Tokyo: AILA.

World Bank (2001) Interim Assistance Strategy for the IRI. Report No. 22056 IRN. http:// www-wds.worldbank.org/servlet/WDSContentServer/WDSP/IB/2001/05/08/0000 94946_0104210950232/Rendered/PDF/multi0page.pdf, accessed 6 March 2008.

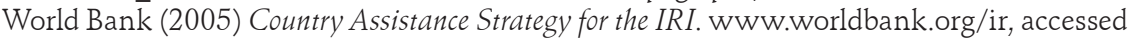
10 March 2008.

World Bank (2008) Country Brieffor the IRI. www.worldbank.org/ir, accessed 10 March 2008.

World Bank (2011) Four Pillars of a Knowledge Economy. http://web.worldbank.org/WBSITE/ EXTERNAL/COUNTRIES/ECAEXT/EXTECAREGTOPKNOECO/0, contentMDK :20422383 menuPK:921081 pagePK:34004173 piPK:34003707 theSitePK:677607,00. html, accessed 17 August 2011.

Yarmohammadi, L. (2005) ESP in Iran from a language planning perspective. In G. Kiany and M. Khayyamdar (eds) Proceedings of the First National ESP/EAP Conference (Vol. II) (pp. 2-20). Tehran: SAMT.

Zabansara (2008) History of Zabansara Language Institute. http://zabansara1.atspace. com/aboutoxford.htm, accessed 28 April 2008.

Ziahosseiny, M. (2005) Key figures in ELT: Professor Seyyed Mohammad Ziahosseiny. ILI Language Teaching Journal (Tehran) 1 (1), 99-106. 


\section{Index}

actors, x, 7, 9-12, 23, 29, 32-33, 38-39, $63,93,107,133,158,161,165$

adaptation, $9,12,18,139$

Africa, $x-x i$, xvii, 6, 32, 34-36, 86

agency, ix-x, 7-8, 10, 12, 28, 36, 53, 107, $143,161,165$

agents of internationalization, 8, 13, 15, $23,35,37-38,64-65,72,83-84,104$, 128, 138, 161, 164, 166

Ahmadinejad, M., viii, xv, xviii, 16, 137-138, 140, 158, 162

American aid, 49, 52-54, 61

American Asia Foundation, 32, 36

American Board of Commissioners for Foreign Missions, 42, 44

American College of Tehran, 45, 52, 86

American educational operations, 59

American missionaryschools, 42, 46, 60

American Presbyterians, 42, 58

Amir Kabir Technological

University, 138

Anglo-American, 4, 6, 13, 161

and Anglo-Americanization, 6-7, 164

antagonism (to the West/US), viii, xvi, 66,140

anti-Western (ideology/policies/ sentiments), viii, $2,5,16,84$, 107, 160, 163

Arabic, 3, 17, 32, 60, 73-75, 79, 87, 95-96, 109, 139, 148, 168

Armenian, 42-44, 46, 59

Association of Professors of English of Iran, 79

Assyrian, 42-43, 59

authenticity, 18, 126 and authentic (textbooks/materials), 6, 126

Banyan tree, 8, 165-166

basij, 136-138

bilateral agreements, 86

and bilateral donors, 10, 33, 36,39

British Angelicas, 42

British Church Missionary Society (CMS), 46-47, 80, 174

British Council, xvi, 4, 9, 14, 28, 31-32, 36-37, 39, 49-51, 53, 57, 59, 61, 71, 80, 119-125, 130-131, 134, 140-143, 158-159, 163-164

British missionary schools, 42, 46-47

British Oil Company, 47

British Overseas Development Agency, 28

Boré, E., 46

borrowers, 7, 10-11, 161

and direct/indirect borrowing, $x, 9-10$, 12-13, 18-19, 24, 26-36, 38-39, 63, 71, 82-83, 86, 91, 105-106, 128, 130, $133,146,151,153,158,161,163$, 165-166

bottom-up policies, 5

brain drain, 67, 147

Bruce, R., 46

business enterprises, 11, 30-31

Bush, G.W., xiv

Cambridge English Language Teaching to Adults (CELTA), 128, 133

celebratory conservatism, 6

center-periphery, 7 
China, 4, 27-28, 39, 81-82, 86, 141

Communicative Language Teaching (CLT), 6, 17-18, 27, 36, 104-105, 126, 145, 165

collaborations (real/phony), x, 53, 77, 95, 107, 109, 113-114, 121, 123 , 128, 130, 132, 134-135, 140-141, 144-146, 156, 158, 163

Cold War, 2, 15, 49, 51-52, 59

communication technology, xviii, 118, 165

communicative competence, 18

communism (and socialism), 2, 3, 66, 68,160

convergence, 8, 12, 18-19

copyright law, 104

Council of Expediency, 114

Council of Guardians, 92, 108

critical perspectives, 7,12

Cuba, 4, 27-28, 38, 81, 86, 94

cultural revolution, 3, 66-69, 71-73, 75-77, 79, 81, 86, 88, 94-96, 119, 127-128, 135, 137, 139, 157-158

curriculum (religious), 27, 30, 36-37, 39-40, 43-44, 47-48, 59, 68-71, 75, 77, 79, 85, 87, 93-95, 100, 104, 107, 109, 115, 124, 149

Dar-al-Fonun, 48

decentralization, 90-93, 103, 107, 113, 133, 148, 163, 165

developmental plans, xvi, 16, 93

digital revolution, 118, 163

direct borrowing (see borrowing)

disciplinary committee, 69, 76

divergence (educational), 8, 18

donors (bilateral/multilateral), 10, 33-34, 36, 39

drill-based English curricula, 6

Eastern Christians, 42

economic motives, 24, 32, 38, 106, 163, 165

educational transfers (politics/causes/ agents), xv, 9-12, 15, 18-19, 23, 26, 29-34, 38-39, 63-64, 166

educational borrowing/lending, vii-viii, 9-13, 18-19, 24, 63, 83, 86, 161

and educational imports/exports, 8 , 10,101 elite networks, x, xiv, 11-12, 29, 79, 84, 124, 130, 164-165

ELT educational transfers, 15, 23, 38-39

and ELT journals, 29-30, 151-152

and ELTmaterials, 105, 127, 146, 150-151

and ELT professional networks, $\mathrm{x}$, xiv, $29,37,165$

enemies, xiii, xv, 3-4, 72, 162

English for Academic Purposes (EAP), 55-57, 97, 126-127

English for General Purposes (EGP), 95, 109

English for Specific Purposes (ESP), 51, 77 and ESP textbooks, 51, 71, 78, 96-101, 118, 126-127, 135

and ESP curriculum, 51, 61, 126

Esperanto, 71-72

European Union (EU), 34

exogenous forces, $\mathrm{x}, 7,39,161$

expansion of English, 115, 118

external forces, ix, 33, 38-39, 137

externalization (implicit/explicit), 9, 11, 24, 84-86, 91, 106, 126, 130, 163

fee-paying students, 31, 35, 103, 128-134

fieldwork in archive, $\mathrm{xv}$

finance organizations, $\mathrm{x}, 34-39,90$

First Development Plan, 90-94, 101, 107

Fiske Seminary, 44

foreign language committee, 73-78

fourth development plan, 112-118

Franklin Publishing Company, 86

French, 42-48, 53-59, 73, 76-77

French Lazarist Catholic, 42, 46

free-market economy, 89-90, 160

Fulbright (Commission), 52-53

fundamentalists, 1, 136

G-7 countries, 108, 112

German, 4, 73, 77, 95, 108-109

German DSE and GTZ, 36

global market-economy, 104, 164

global outlook (period), 16, 64, 84, 110-135, 165, 110-135

global reforms, 9

globalization, ix, 7-8, 12, 138, 148, 162, 165

glorification, 28 
governance of religious jurisprudence, 1 grammar translation (method), 54, 98, 105 Great Satan, xiii, 4, 71, 14

harmonization, 33-35

Hashemi-Rafsanjani, A. (see Rafsanjani)

Headquarters of the Cultural Revolution (also see Supreme Council of Cultural Revolution), 66-73

Headway, 104-105

homegrown, 1-2, 27, 157, 164 and homegrown textbooks, 4-5, 69, 74-78, 94

Hong Kong, 25, 35, 128

human capital, 24-25, 81, 94

IELTS, 122, 129, 131, 141-142, 147, 157 India, 17, 30, 36, 39, 41, 60, 82, 87, 152 indigenization (movement), 1-5, 12-13, $16,27,29,63,66-67,84-85,94$, 137-139, 158, 161-164 and indigenized education, 77 and indigenized English, x, 1, 134 information technology, 14, 113, 119, $124,134,143,149,162-163$

INGO, 10, 33, 36-37, 39

Instructors' Training University, 61, 75-76, 126, 135, 155

Interchange, 19, 52, 104, 145

international ELT professional network, 37

international publishers, 101, 107, 143, 158, 163

international standards, 9, 163

internationalization, 9, 13-16, 63, 102, 133, 145, 161, 164

internationalized English, 16, 50, 122, 132, 157-158

invisible lenders, 101

Iran-America Society (also Iran-America Cultural Society), 4, 50, 53, 57, 59, 61, 71, 80, 125

Iran-America relations, 51

Iran-Australia (school), 131

Iranian-Canada (school), 131

Iran-Iraq War, 16, 64, 89, 101

Iran Language Institute (ILI) (also see Iran-America Society), 57, 71, 80, 125

ILI Language Teaching Journal, 125
Iranian Journal of Applied Linguistics (IJAL), 124

ISESCO, 95, 109

Isfahan, 44-47, 50-51, 56-57, 61

Islamic Association, 69

Islamic theocracy, 160

Islamic Umma (See Umma)

Islamization, 2-3, 67-69, 79, 106, 109, $135,137,158$

isolation policies, 16, 146

Jordan, S., 41, 51-52

Kenya, 28, 32, 36, 39

Kish Language Institute, 103-104, 128, 145

Khatami, M., xiii, xiv, 16, 110-115, 133-135, 137, 140, 163, 165

Khamenei, A., 75, 114, 119

Khomeini, R., x, 2, 4, 16-17, 65-72, 76, 78, 81, 86, 90, 104, 107-108, 134, $136,146,162$

knowledge-based economy, 113, 133, 134, 163,165

Konkur, 79, 100, 109

Kurdish, 34

Latvia, 34

lenders, viii, 10-12, 101, 161

liberal idealism, 6

lingua franca, 41-42, 48, 59-60, 87

linguistic hybridity, 7, 161

linguistic imperialism, x, 4, 30, 37-38, 71, 76, 161

localization (also see indigenization), 3, 5, $13,138,161$

local borrowers, 7, 161

loans, 34-35, 91, 112, 158

and loan conditionality, 34, 165

Malaysia, 25, 28, 31, 38-39

Marshall Plan, 49

Middle East, xvii, 26, 46, 49, 113

Ministry of Culture and Islamic Guidance, 88, 103, 105, 109, 127-128, 139-140, 145, 148

Ministry of Higher Education, 67, 80-81, $87,116,121$

Ministry of Science, Research and Technology, 115 
missionary schools, 42, 46-50, 60

modernization, 2, 6, 17, 26, 48, 107, 115-116

Mo'in, M., 11, 114

Mongolia, 36

Moshiriyeh, 48

multi-level analysis, ix

national forces, ix, xvi, 10-11, 14-17, 23-29, 31-34, 38-39, 64, 79-80, 86, $102,107,128,133-134,161-165$

nation-state, xvi, 10-13, 23, 29, 63, 102, 159, 166

negative internal/external evaluations, 24, 28-30, 39, 49, 106, 133, 163

new institutionalism, 18

NGO, 10, 33, 35-39

normative perspective (also see liberal idealism), 6

normative, 6-7, 31, 160

OECD, 153-154

Pahlavi dynasty, 16, 48, 59, 66, 162 and Pahlavi, M.R. Shah, 2, 47, 49 and Pahlavi, R. Shah, 2, 47-49, 60, 108

and Pahlavi University (also see Shiraz University), 55, 75

Pakistan, 32, 36, 39, 81-82

Parsa, F., 62

partnership, 112-115

Perkins, J., 42-44

penetration, $x, 33-34$

period of global outlook, 16, 84, 110, 165

period of reconstruction, 16, 89, 94, 106, 163-164

Persia (Persis), 17, 40

Persian, 4, 17, 41-55, 60, 62, 73-75, 87

Philippine, 25, 38

phony policies, 27

pirating books, 28, 76-77, 104-106, 130-132, 146-150, 165

pious professors, 75-76, 155

Plan and Budget Organization, 90

Point Four Program, 53

policy action, 9-12, 18, 118, 154

and policy borrowing/lending (see borrowing) and policy documents, xvi, 16, 91

and policy emulation, 24, 163

and policy implementation, xiv, 9, 12 ,

35,114

and policy lessons, 24, 85, 91, 162

and policy privatization (see

privatization)

and policy transfer, 24, 33, 134

and policy stages, $11-15$

postmodern, 7

political motives, ix, 26, 163

pragmatics, 98

pre-Revolutionary (textbooks), 4-5

privatization (also see Policy), 16, 35, 89-94, 106-108, 112-113, 133, 158, 163-165

private language institutes, $31,35,80$, 104, 107, 127-134, 144-146

private schools, 35,93

professionalization of ELT, 124

professional tribalism, 29

publishers (publishing press), 101, 107, 109, 143-144, 146-147, 163, 165

professional elite networks (see elite networks)

Pune University, 30, 39

purification, 3, 67-69, 71, 79, 106, 109, 135, 137-138, 158

Qajar dynasty, 40, 48, 58

Qatar, 26

qualitative decline/growth

(of education) 115

quick fix solutions, 11

radicals, 90

Rafsanjani, A. (also see Hashemi-

Rafsanjani), 16, 68, 74, 89-90, 93, 101, 106, 108, 114, 164

receptiveness, $11,13,27,106,111$, 163-164

reference societies, 10, 80-81, 91, 107, 119,163

reform (period), 26-28, 53-55, 59, 66, 69

reformist administration, 110, 133, 140

reform package, 113-115, 118, 133

re-Indigenization (movement), 137

reconstruction (period), 16-17, 81, 91, 94, 106, 112, 163-64 
research (output/production), xv-xvii, 6 , $7,9,12,14-15$

research-based Universities, 115 resisting linguistic imperialism, 71 revolution (1979), xviii, 1-3, 65-66 revolution (velvet/Soft), xiii-xiv, 137 Revolutionary Guards, 136-137 revolutionary period, 16, 64-65, 83 Russia, xii, 4, 27, 38, 40, 49

Russian, 27, 34, 44, 48, 73, 77, 147

Sadiq, I., 48, 53, 61-62

Sage College, 45

SAMT, 4, 17, 69, 78, 85, 87, 96-98, $126-127,135,150$

satanic, 13

Saudi Arabia, 26

scandalization, 28

school privatization, 35, 91-93

Second Development Plan, 91, 93-94, 101, 108-109.

Secular (curriculum/textbooks), 3, 41, 48, 66, 68, 72, 75, 85, 109, 138

Shahnama, 87

Sharif Technological University, 108

Shiraz University (see Pahlavi University), 75, 77-78, 126, 135

Shiite, 40-41, 70, 75, 162

Singapore, 25, 38, 152

Shokuh, M. (also institute), 57-8, 72, 80, 103, 145

Socialism (see communism), 2, 3, 66,160

Sri Lanka, 32, 36, 39

state ambivalence, 156 and state intervention, xvi, 145, 165 and State Translation House, 47-48

Stewart Memorial College, 47

structural adjustment policy, 35, 39, 91, 107

student-centered, 6, 17, 104-105, 165

subnational forces, xvi, 11, 17, 23, 29, 31-33, 39, 79, 102, 107, 133-134, 161, 164-165

supranational forces, xvi, 10, 14, 15, 17, $23,33-34,38-39,64,80,86,126$, $161,163-164$

Supreme Council of Cultural Revolution, 127
Supreme Council of Information

Technology, 119

Syria, 17, 36, 81-82

Swiss Development Agency, 36

TAKFA, xviii

Taiwan, 25, 38

Tanzania, 35, 36, 39

task-Based instruction, 6

TEFL, 57, 61, 75, 79, 83, 96, 98, 101-102, 118, 121, 126, 133, 135, 147, 150-156

Tehran annual international book fair, 101-102, 163

Tehran Boys' School, 45

Tehran Teachers' Training University, 57, 61, 124, 135

Teaching English Language and Literature Society of Iran (TELLSI), 61, 121, 125, 135, 182

Textbooks (ELT), 4, 6-9, 12-13, 15, 17, 23-39, 51, 62, 64, 71, 84, 101-102, $105,107,120,124-130,133-134$, 143-144, 146, 150-152, 155, 158, $165-166$

Thailand, 25, 38

Third Development Plan (see Development Plans), 112, 154

TOEFL, 129, 147, 157,

transnational education models, 115 and transnational organizations, $x v i$, $10,14,33,39,112,133,158,165$

traveling policies, 113, 166

Turkey, 34, 41, 48, 60, 81-82, 152

Turkish, 32, 42-44, 48, 60, 147

Uganda, 28, 36, 39

Umma (See Islamic Umma), 3, 162

United Arab Emirates, 26

United Kingdom (UK), xiii, 30, 82-84, 86, 104, 107, 122-123, 140, 142,146

United Nations (UN), 112, 135

UN Human Development plan, 113

UNDP, 112, 135

UNESCO, 36, 112, 135

UNFPA, 112, 135

UNICEF, 112, 135

UNODC, 112, 135 
United States (USA), xiii-xiv, xviii, 2, 4-5, 27, 34, 44-46, 49-53, 59, 61, 66, 71, 73, 82-84, 86, 91, 108-109, 134, 146, 150

University Crusade, 69-70

University of Mashhad, 56

University of Shiraz, 55

USAID, 36, 53, 55

velvet revolution (also see soft revolution), xiii-xiv, 137

Vision Plan, 114
Westernization, 2, 138, 164

World Bank, x, xvi, 14, 16, 34-36, 39, 90-91, 103, 107-108, 112-113, 115, 133-135, 158, $163,165,169-171$

World Conference of Higher Education, 111

World Culture Theory, 18

Zabansara (language institute), 103, 130-32 